Prepared for the U.S. Army Corps of Engineers

Portland District, Portland, Oregon

under a Related Services Agreement

with the U.S. Department of Energy

Contract DE-AC05-76RL01830

\title{
Survival of Juvenile Chinook Salmon Passing the Bonneville Dam Spillway in 2007
}

\author{
FINAL REPORT
}

GR Ploskey

MA Weiland

JS Hughes

SR Zimmerman

RE Durham

ES Fischer

$\mathrm{J}$ Kim

RL Townsend

JR Skalski

RA Buchanan

RL McComas

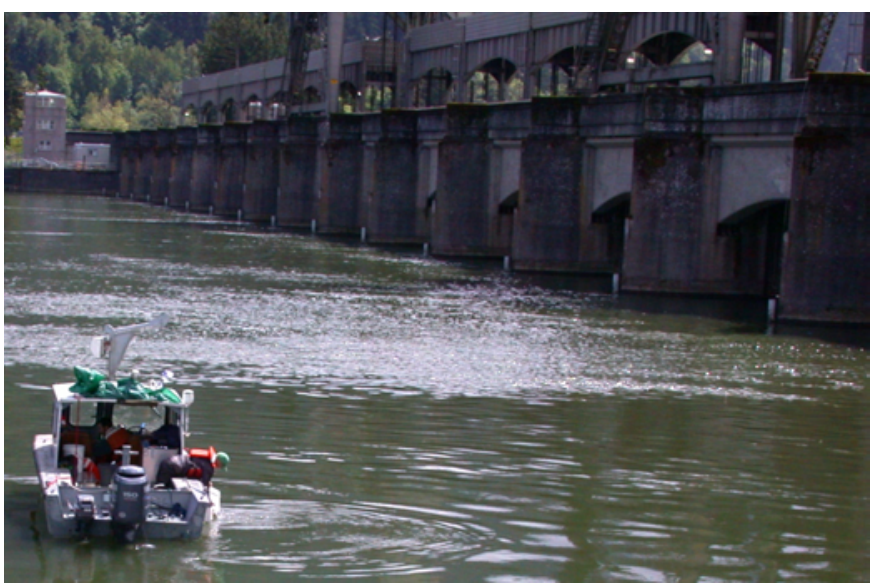

December 2008

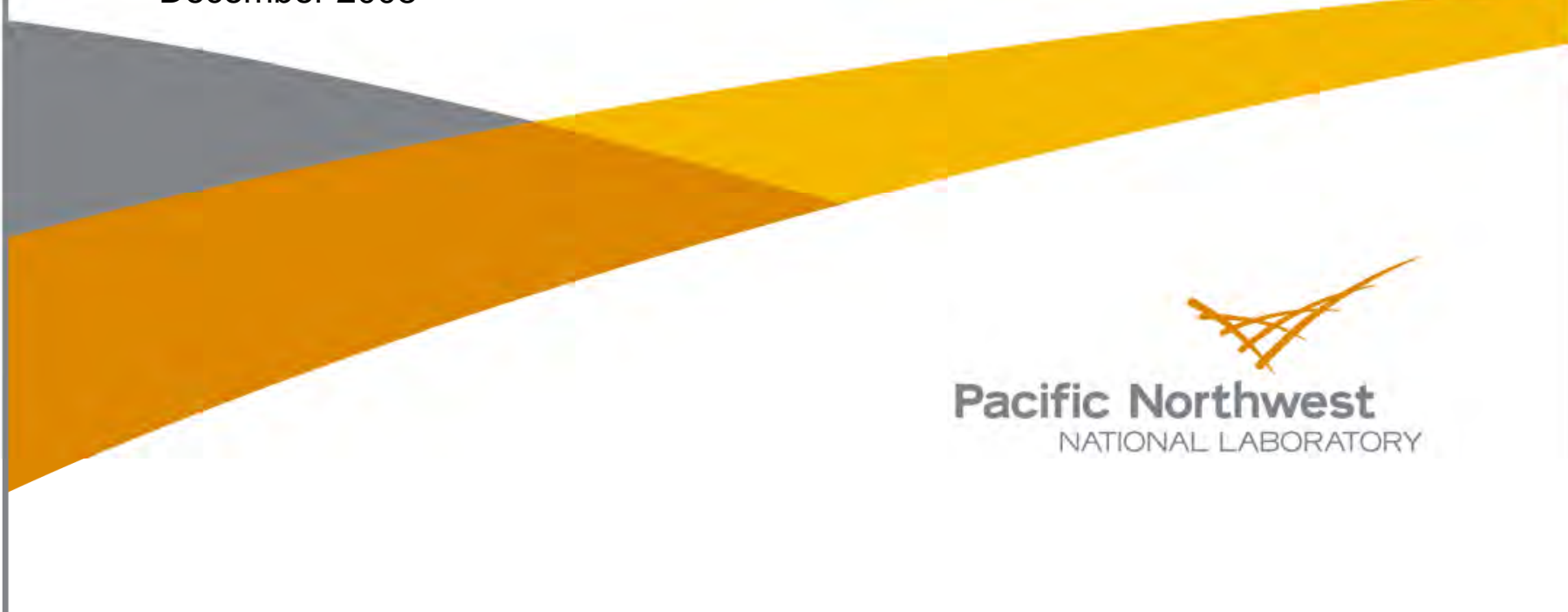




\title{
DISCLAIMER
}

This report was prepared as an account of work sponsored by an agency of the United States Government. Neither the United States Government nor any agency thereof, nor Battelle Memorial Institute, nor any of their employees, makes any warranty, express or implied, or assumes any legal liability or responsibility for the accuracy, completeness, or usefulness of any information, apparatus, product, or process disclosed, or represents that its use would not infringe privately owned rights. Reference herein to any specific commercial product, process, or service by trade name, trademark, manufacturer, or otherwise does not necessarily constitute or imply its endorsement, recommendation, or favoring by the United States Government or any agency thereof, or Battelle Memorial Institute. The views and opinions of authors expressed herein do not necessarily state or reflect those of the United States Government or any agency thereof.

\author{
PACIFIC NORTHWEST NATIONAL LABORATORY \\ operated by \\ BATTELLE \\ for the \\ UNITED STATES DEPARTMENT OF ENERGY \\ under Contract DE-AC05-76RL01830
}

Printed in the United States of America
Available to DOE and DOE contractors from the
Office of Scientific and Technical Information,
P.O. Box 62, Oak Ridge, TN 37831-0062;
ph: (865) 576-8401
fax: (865) 576-5728
email: reports@adonis.osti.gov

\author{
Available to the public from the National Technical Information Service, \\ U.S. Department of Commerce, 5285 Port Royal Rd., Springfield, VA 22161 \\ ph: (800) 553-6847 \\ fax: (703) 605-6900 \\ email: orders $a$ ntis.fedworld.gov \\ online ordering: http://www.ntis.gov/ordering.htm
}




\section{Survival of Juvenile Chinook Salmon Passing the Bonneville Dam Spillway in 2007}

FINAL REPORT

$\begin{array}{ll}\text { GR Ploskey } & \text { J Kim }^{1} \\ \text { MA Weiland } & \text { RL Townsend }{ }^{2} \\ \text { JS Hughes } & \text { JR Skalski }^{2} \\ \text { SR Zimmerman } & \text { RA Buchanan } \\ \text { RE Durham } & \text { RL McComas } \\ \text { ES Fischer }^{1} & \end{array}$

December 2008

Prepared for the U.S. Army Corps of Engineers

Portland District, Portland, Oregon

under a Related Services Agreement

with the U.S. Department of Energy

Contract DE-AC05-76RL01830

Pacific Northwest National Laboratory

Richland, Washington 99352

${ }^{1}$ Pacific States Marine Fisheries Commission

${ }^{2}$ University of Washington

${ }^{3}$ National Marine Fisheries Service 



\section{Executive Summary}

In 2007, the Portland District of the U.S. Army Corps of Engineers contracted with the Pacific Northwest National Laboratory (PNNL) to conduct an acoustic telemetry study to estimate the survival of juvenile Chinook salmon passing the spillway at Bonneville Dam. Fish longer than $95 \mathrm{~mm}$ were surgically implanted with Juvenile Acoustic Telemetry System (JSATS) and passive integrated transponder (PIT) tags, held overnight in tanks supplied with continuous flow of river water to allow time for recovery from surgery, and released between 1400 and 1700 hours on 16 days in spring and 14 days in summer. Some fish were released in the spillway forebay above the dam to create treatment-release groups that would pass through the spillway, and other fish were released $2 \mathrm{~km}$ downstream of the spillway in the tailrace to create reference-release groups that did not pass through the spillway. Reference releases in the tailrace began about 1 hour after the start of treatment releases in the forebay so that both groups would mix and pass through the common downstream tailwater about the same time of day. The common tailwater for our survival estimates was from the tailrace-release site $2 \mathrm{~km}$ downstream of the dam to the first or second of three tag-detection arrays located downstream of the dam. An array is a group of autonomous underwater receivers (nodes) deployed to listen for acoustic tags passing through an entire cross section of the river. Treatment fish were exposed to passage through $<76 \mathrm{~m}$ of spillway forebay, spill bays, and $2 \mathrm{~km}$ of tailrace that the reference-release groups avoided. Single-release estimates included survival from the point of release to the primary detection array or from the primary array to the secondary array and included losses of fish in the common tailwater. Paired-release survival estimates for spillway-passed fish to the tailrace-release site were calculated as the ratio of the survivals of treatment-release groups to the survivals of paired reference-release groups to remove effects of losses of fish in the common tailwater. The PNNL team released treatment fish in the forebay and a National Oceanic and Atmospheric Administration Fisheries team released reference fish in the tailrace. Some treatment fish were detected by spillway hydrophones and assigned a bay of passage based upon the location of the last of at least four detections of implanted acoustic tags. Detections of PIT tags in the Powerhouse 2 (B2) Corner Collector (B2CC) and B2 Juvenile Bypass System (B2 JBS) were used to assign non-spillway routes of passage. Routes of spillway passage included end bays 1 through 3 and 16

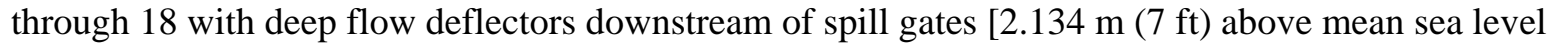
(MSL)], and middle bays 4 through 15 with shallow flow deflectors [4.267 m (14 ft) above MSL]. Single- and paired-release estimates of survival were calculated from detection histories for tagged fish by release location and route of passage based on subsequent detections on three tailwater survival arrays located approximately 25, 34.4, and $42.4 \mathrm{~km}$ downstream of the dam.

\section{Major Findings}

We only tagged fish longer than $95 \mathrm{~mm}$ to avoid overburdening small fish and inducing unnecessary tag effects. This 95-mm minimum length for tagging did not restrict the lengths of fish that could be tagged in spring because the length of almost all yearlings exceeded $95 \mathrm{~mm}$, and the frequencies of tagged and untagged yearling Chinook salmon in the JBS samples being of similar length were very similar. In contrast, the 95-mm minimum length to be eligible for tagging effectively eliminated about $39.5 \%$ of the run-of-river subyearlings from the tagging sample because they were too small. This percent exclusion was 15 to $20 \%$ less than that of previous radiotelemetry studies that used a 130 -mm-length-limit criterion, but it was still too high. Tagging would need to include 75-to-95-mm-long subyearlings to be fully representative of the population passing through the Bonneville Dam Juvenile Monitoring Facility in 
summer. Further miniaturization of JSATS acoustic tags will be required to allow tagging of 75-to-95mm subyearlings in the future.

Detection probabilities used for survival calculations were more than adequate to provide robust estimates for the entire spillway each season. We recorded no detection probabilities for single releases that were $<75 \%$, and the average for the primary array detection probability was $92.7 \%$ in spring and $98.8 \%$ in summer. The average detection probability for the secondary array was $87.5 \%$ in spring and $96.6 \%$ in summer. Detection probabilities were higher in summer than in spring because detection probabilities were inversely related to river discharge.

For spring, the weighted-average, paired-release estimate of survival of yearling Chinook salmon, corrected for tag life and a single dead-fish detection was 0.937 [95\% confidence interval (CI) $=0.911$, 0.964]. Uncorrected for the dead-fish detection, the weighted-average, paired-release estimate was 0.957 (95\% CI $=0.931,0.970)$. The tag-life correction was made for 2007 Sonic Concepts tags because a couple of fish did not pass survival arrays before there was a probability of tag failure, but the correction only increased survival in the third decimal place of the estimate. Survival adjusted for detecting a single dead fish was calculated assuming a dead-fish detection probability (ㅁ) of 0.0126 (2 out of 159 released dead fish detected over 3 years) and the following equation:

$$
E(\tilde{S} \mid \hat{D})=\frac{S_{1}+\left(1-S_{1}\right) \hat{D}-\frac{\hat{D}}{p}}{S_{2}\left(1-\frac{\hat{D}}{p}\right)}
$$

where

$S_{1}=$ survival of fish from upstream release $R_{1}$ to the first detection array

$S_{2}=$ survival of fish from downstream release $R_{2}$ to the first detection array

$p$ = probability of detecting a tagged fish at the first array

$D=$ probability a dead fish from release $R_{1}$ migrates and is detected at the first array

such that, if $D=0, \tilde{S}=\frac{S_{1}}{S_{2}}=S_{\text {Project }}$.

The variance of with respect to $\hat{D}$ can be estimated by the delta method to be

$$
\operatorname{Var}_{\hat{D}}[E(\tilde{S} \mid \hat{D})]=\frac{D(1-D)}{n}\left[\frac{\left[\left(1-S_{1}\right) p-1\right]}{S_{2}(p-D)}+\frac{\left[S_{1}^{2} p+S_{1}\left(1-S_{1}\right) D p-S_{1} D\right]}{S_{2}^{2}(p-D)}\right]
$$

where $n=$ number of dead tagged fish released below the dam. The contribution of estimating the dead-fish detection rate on the overall variance of a project survival estimate can be calculated. The square root of the equation for the variance with respect to $\hat{D}$ provides a rough approximate value of how much the standard error (SE) of a project survival estimate will increase because of dead-fish detections. 
We recommend releasing at least 50 dead tagged fish below the dam each season during future survival studies at Bonneville Dam to better quantify the dead-fish-detection probability. The single dead fish detected on two survival arrays also was subsequently detected on four other arrays, the last of which was $177 \mathrm{~km}$ below the dam and within $42 \mathrm{~km}$ of Astoria, Oregon. Consequently, relocating survival arrays $>100 \mathrm{~km}$ downstream would not have avoided the detection of a dead fish in 2007. To avoid sacrificing a lot of fish for future dead-fish releases, we recommend using dead specimens found before rigor mortis is obvious during routine smolt-monitoring operations as well as any fish that happen to die as a result of tagging (a common practice). Recently deceased fish also could be collected from the Bonneville Hatchery and refrigerated for 1 to 2 days until needed, although reasonable condition criteria would have to be established. If fish must be sacrificed, we recommend sacrificing individuals that would otherwise be rejected for tagging because of injury or descaling. These individuals would be much less likely to survive than healthy fish.

For spring, we found no effect of spill-bay deflector type on survival, because estimates were based on very small sample sizes of tracked fish (167 yearlings tracked to middle bays and 114 tracked to end bays), and 95\% CIs were very wide $\left(0.849 \leq\right.$ Relative Survival to Array $\left.1\left(\mathrm{RS}_{1}\right) \leq 1.089\right)$. The spring season was a valuable problem-solving exercise for sampling the noisy spillway environment at Bonneville Dam. We quickly discovered that very few tagged fish were being detected on star clusters, and we scrambled to deploy hydrophones on piers during the second week of operation. The performance of pier hydrophones also was poor until baffles were installed on individual hydrophones by the end of the third week to dampen noise emanating from the direction of spill gates. We recommend that the spring test be repeated, because by the end of summer the combination of baffled hydrophones, tuned detector software, and second-generation decoder software were detecting approximately $80 \%$ of all acoustic tags released in the forebay. Numbers of fish tracked to bays with the two deflector elevations must be high because suspect causal mechanisms (i.e., low discharge and low tailrace pool elevations) are less common in spring than they are in summer.

Across the 14 days of paired releases during summer, we estimated a weighted-average, pairedrelease survival of $\hat{s}_{\text {sinl }}=0.930(\widehat{\mathrm{SE}}=0.007)$ for subyearlings passing the spillway. The $95 \% \mathrm{CI}$ was $0.917 \leq \hat{s} \leq 0.945$. There was no need for tag-life or dead-fish detection adjustments in summer.

For summer, juvenile fish passing middle bays with shallow flow deflectors [4.267 m (14 ft) above MSL] had significantly lower survival $\left(t_{26}=-2.538, P=0.0087\right)$ through the first reach but not in the second reach $(P=0.9736)$ than did counterparts passing end bays with flow deflectors installed at 2.134 $\mathrm{m}(7 \mathrm{ft})$ above MSL. The first-reach result was expected under the alternative hypothesis that fish have higher passage survival in the deep deflector spill bays than in the shallow deflector spill bays. The lack of effect in the second reach may indicate that most mortality associated with bay passage had already occurred. For the shallow flow deflector releases, a weighted-average survival from Bonneville Dam to the primary downstream array was $0.936(\widehat{\mathrm{SE}}=0.008)$. For the deep flow deflector releases, the weighted-average survival for that same initial reach was $0.999(\widehat{\mathrm{SE}}=0.002)$. For both treatment groups, reach survival between primary and secondary arrays was estimated to be 1.0. Estimates of single-release survival were based on tracking 1105 summer Chinook salmon smolts to bays with shallow flow deflectors and another 892 to bays with deep flow deflectors.

Results were confirmed by examining estimates of relative survival (RS) based on a log-link, normal error structure and weighting by $1 / \mathrm{CV}^{2}\left(1 /\right.$ Coefficient of Variation $\left.{ }^{2}\right)$. Survival estimates for fish passing end bays and middle bays were significantly different from each other in the first reach $\left(t_{26}=2.505, P=\right.$ 
0.0188 ) but not in the second reach $\left(t_{26}=-0.650, P=0.5212\right)$. Using a weighted average of the individual RS estimates (deep and/or shallow) across trials produced an estimate of RS1 $=1.025$ ( $\widehat{\mathrm{SE}}=$ $0.009)$ from Bonneville Dam to the primary array $(\mathrm{CI}(1.006<\mathrm{RS} 1<1.044)=0.95$. These results also were consistent with the alternative hypothesis that survival through the deep flow deflectors would be better than through the shallow flow deflectors. For the reach between primary and secondary arrays, relative survival of deep-to-shallow deflector spill bay passage was estimated to be RS2 $=0.999$ ( $\widehat{\mathrm{SE}}=$ 0.001). For the first reach, 8 of 14 ratio estimates exceeded 1, 4 of 14 were close to 1, and only 2 were below 1 . For the second reach, the pattern of deviations did not have a positive or negative tendency.

The most likely environmental conditions reducing survival of subyearling Chinook salmon passing bays with shallow flow deflectors are below average project discharge and low-tailrace elevations in summer. Below-average project discharge resulted in low tailwater elevations that were often within $1 \mathrm{~m}$ of shallow flow deflectors in summer. In contrast, project discharge was similar to the 10-year average in spring, and tailrace elevations were mostly in the range of 6.1 to $7.0 \mathrm{~m}$ above MSL. The lowest tailrace elevations observed for about 4 days in spring were at least $5.5 \mathrm{~m}$ above MSL, and we observed no significant difference in survival of fish passing bays with shallow and deep flow deflectors, although statistical power was poor in spring.

Mechanisms for increased mortality when tailrace elevations are within $1 \mathrm{~m}$ of shallow flow deflectors at middle bays are unknown, but we can speculate that the proximity of fish to deflector surfaces decreases as the amount of water passing over deflectors decreases. In the early 1970s, Johnson and Dawley (1974) found that fall Chinook salmon passing bays without flow deflectors had higher survival (95.8\%) than subyearlings passing bays with flow deflectors (86.8\%). Any injury or loss of equilibrium associated with abrasion or shear could increase susceptibility of fish to predation or disease so there could be immediate or delayed mortality. For subyearlings in summer, we found that the mean travel time to the egress array located $9 \mathrm{~km}$ downstream of the dam was 20 minutes longer $(\mathrm{P}=0.0105)$ for fish passing middle bays with shallow flow deflectors (2.58 hours) than it was for fish passing end bays with deep deflectors (2.26 hours). 


\section{Preface}

The U.S. Army Corps of Engineers (USACE) Portland District (CENWP), contracted with the Pacific Northwest National Laboratory (PNNL), Richland, Washington, to conduct an acoustic telemetry survival study at the Bonneville Dam spillway in 2007. PNNL assembled a study team consisting of staff from PNNL, the Pacific States Marine Fisheries Commission (PSMFC), the University of Washington, and the National Marine Fisheries Service. The Portland District provided all funding and oversight. 



\section{Acknowledgments}

Many people made valuable contributions to this study and deserve acknowledgment. Mr. Dennis Schwartz served as the USACE Contracting Officers Technical Representative and provided valuable coordination between researchers and Bonneville Dam personnel. Mr. Brad Eppard contributed many valuable suggestions on study design and implementation, furnished dam operations data, and reviewed the draft report. Mr. Robert Johnson of the USACE Walla Walla District also reviewed the draft report.

Ben Hausman, with the Bonneville Project, provided pre-work safety orientations and he, Tim Darland, Tammy Mackey, and Jonathon Rerecich facilitated coordination between researchers and the Bonneville Project whenever needed. The project provided crane support to deploy star clusters in the spillway forebay, supplied electricity to trailers on the north and south ends of the spillway, and set up clearances on the electric bus line supplying power to cranes on the spillway when researchers needed pier access.

Many PNNL staff assisted in project management (Geoff McMichael and David Geist), surgery training (Rich Brown and Kate Deters), fish collection (Robin Durham), fish transport and release (Bob Fulton $^{1}$ ), tag-life monitoring (Rich Brown and Kathleen Carter), Juvenile Salmon Acoustic Telemetry System development (Eric Choi, Brian LaMarche, Daniel Deng, Thomas Seim, and Thomas Carlson), deployment and retrieval of spillway hydrophones (Fenton Kahn), deployment and retrieval of autonomous nodes (James Hearsey and Cherylyn Tunnicliffe), and database entry and management (Jessica Carter). Dr. David Geist was the Ecology Group Manager within PNNL, and Dr. Charlie Brandt was the Program Line Manager.

Staff from National Oceanic and Atmospheric Administration (NOAA) Fisheries coordinated activities (Lyle Gilbreath), participated on the fish tagging team (Lynn McComas, Jason Everett, and Dean Brege), and released fish in the Bonneville Dam tailrace (Jason Everett, Dean Brege, Steve Brewer, Jeff Mosher, and Galan Wolf).

The Pacific States Marine Fishery Commission (PSMFC) contributed many staff who worked on the fish-tagging team alongside NOAA Fisheries and PNNL personnel. These staff included Lila Charlton, Laura Leighton, Drew Guest, Sonna McComas, Eric Fischer, and Jina Kim. Dean Ballinger was the PSMFC supervisor at the Juvenile Monitoring Facility.

Sonic Concepts in Seattle, Washington, fabricated electronic tags for spring tagging and all receiving hydrophones and repaired broken hydrophones when needed. Advanced Telemetry Systems (ATS), Inc. made acoustic tags used in summer. Precision Acoustic Systems, also in Seattle, conducted node acceptance tests for PNNL. Cascade Aquatics, Inc. in Ellensberg, Washington, activated and delivered the acoustic tags. Schlosser Machine Shop fabricated anchors for autonomous nodes and frames for star clusters that were deployed in the spillway forebay.

\footnotetext{
${ }^{1}$ Sadly, Bob Fulton, who we believe is in the cover photo releasing fish, passed away in 2008.
} 



\section{Acronyms and Abbreviations}

\begin{tabular}{|c|c|}
\hline ANODEV & analysis of deviance \\
\hline ATS & Advanced Telemetry Systems ${ }^{\circledR}$ \\
\hline B1 & Bonneville Powerhouse 1 \\
\hline B2 & Bonneville Powerhouse 2 \\
\hline B2CC & Bonneville Powerhouse 2 Corner Collector \\
\hline B2 JBS & Bonneville Powerhouse 2 Juvenile Bypass System \\
\hline $\mathrm{BiOp}$ & Biological Opinion \\
\hline $\mathrm{BON}$ & Bonneville Dam \\
\hline BONO & egress survival array \\
\hline BON1 & primary survival array \\
\hline BON2 & secondary survival array \\
\hline BON4 & tertiary survival array \\
\hline BPA & Bonneville Power Administration \\
\hline${ }^{\circ} \mathrm{C}$ & degree(s) Celsius or Centigrade \\
\hline CENWP & Corps of Engineers, Northwest, Portland \\
\hline $\mathrm{CF}$ & CompactFlash (card) \\
\hline $\mathrm{cfs}$ & cubic feet per second \\
\hline CI & confidence interval (95\% unless specified otherwise) \\
\hline CJS & Cormack-Jolly-Seber model \\
\hline CL & confidence limit \\
\hline $\mathrm{cm}$ & centimeter(s) \\
\hline CSV & comma-separated variables \\
\hline $\mathrm{CV}^{2}$ & coefficient of variation squared \\
\hline $\mathrm{D}$ & dead-fish detection probability \\
\hline DART & Data Access in Real Time \\
\hline FCRPS & Federal Columbia River Power System \\
\hline $\mathrm{ft}$ & foot(feet) \\
\hline g & $\operatorname{gram}(\mathrm{s})$ \\
\hline gal & gallon(s) \\
\hline GB & gigabyte(s) \\
\hline GPS & global positioning system \\
\hline $\mathrm{hr}$ & hour(s) \\
\hline JBS & Juvenile Bypass System \\
\hline JMF & Juvenile Monitoring Facility below the Second Powerhouse (B2) \\
\hline JSATS & Juvenile Salmon Acoustic Telemetry System \\
\hline $\mathrm{km}$ & kilometer(s) \\
\hline
\end{tabular}




\begin{tabular}{ll} 
l & liter(s) \\
LED & light-emitting diode \\
$\mathrm{m}$ & meter \\
$\mathrm{mg} / \mathrm{l}$ & milligram(s) per liter \\
$\mathrm{ml}$ & milliliter(s) \\
$\mathrm{mm}$ & millimeter(s) \\
$\mathrm{m} / \mathrm{s}$ & meter(s) per second \\
MS-222 & tricaine methanesulfonate \\
MSL & mean sea level \\
NOAA & National Oceanic and Atmospheric Administration \\
$\mathrm{O}_{2}$ & oxygen \\
$\mathrm{p}_{1}, \mathrm{p}_{2}$ & mean detection probability \\
PAS & Precision Acoustic System \\
PIT & passive integrated transponder \\
PNNL & Pacific Northwest National Laboratory \\
PR & paired release \\
PSMFC & Pacific States Marine Fisheries Commission \\
PVC & polyvinyl chloride \\
rkm & river kilometer \\
RS & relative survival \\
s & second(s) \\
SAN & Location of nodes deployed near the Sandy River delta \\
SAS & Statistical Analysis System \\
SC & Sonic Concepts \\
SE & standard error \\
SYC & subyearling Chinook salmon \\
TDG & total dissolved gas \\
USACE & U.S. Army Corps of Engineers \\
UTM & Universal Transverse Mercator (a global positioning grid system) \\
YC & \\
& yearling Chinook salmon \\
\hline
\end{tabular}




\section{Contents}

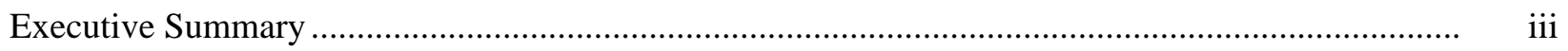

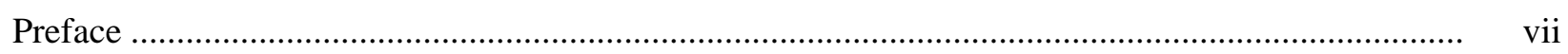

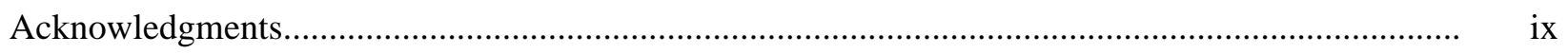

Acronyms and Abbreviations ................................................................................................

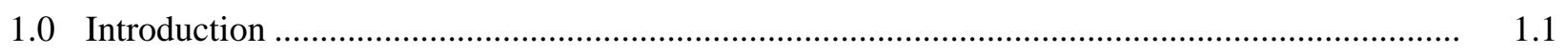

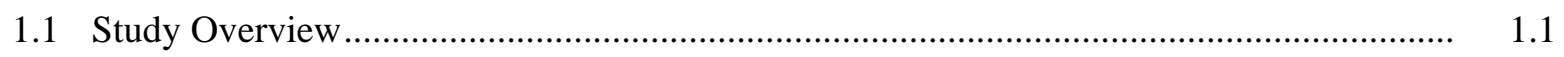

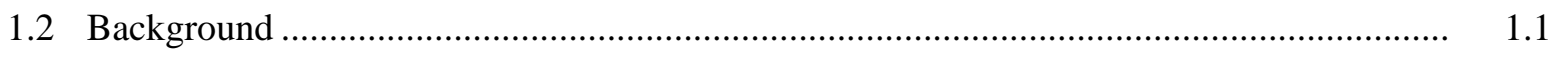

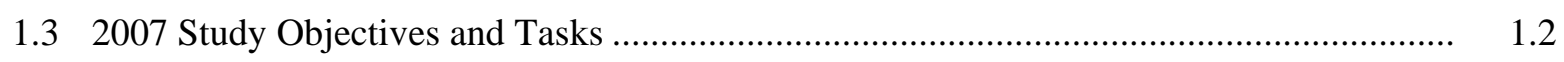

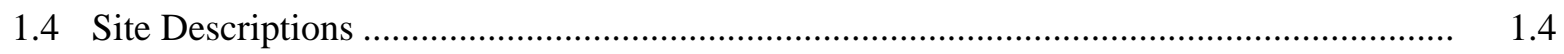

1.5 Report Contents and Organization .......................................................................... 1.5

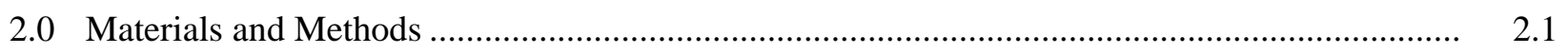

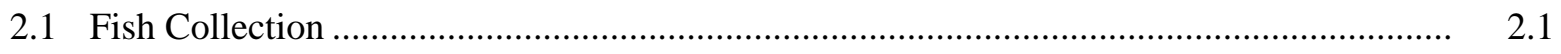

2.1.1 Site Description ........................................................................................... 2.1

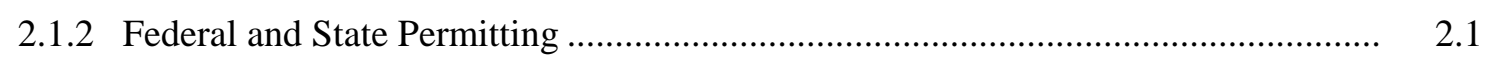

2.1.3 Sampling Methods........................................................................................ 2.2

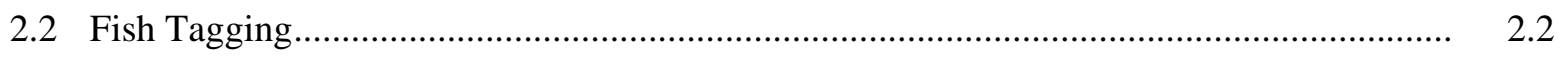

2.2.1 JSATS Acoustic Micro-Transmitter............................................................... 2.2

2.2.2 Tagging Procedure ............................................................................................ 2.3

2.2.3 Recovery and Holding................................................................................... 2.4

2.3 Transport and Release .................................................................................... 2.5

2.4 Steps Taken to Minimize Handling Impacts ................................................................... 2.9

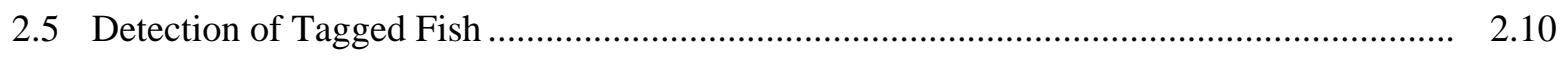

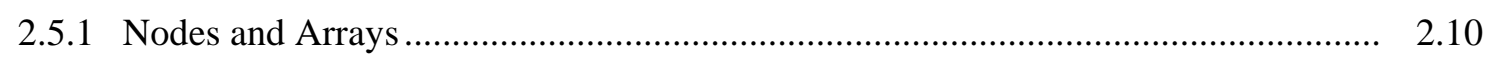

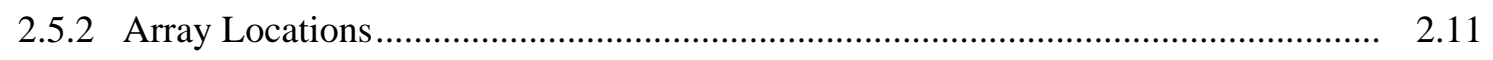

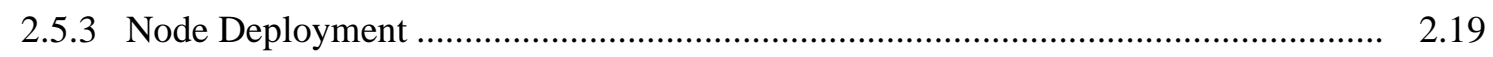

2.5.4 Node Retrieval, Servicing, and Redeployment ................................................. 2.19

2.6 Project Discharge and Water Temperature ................................................................... 2.20

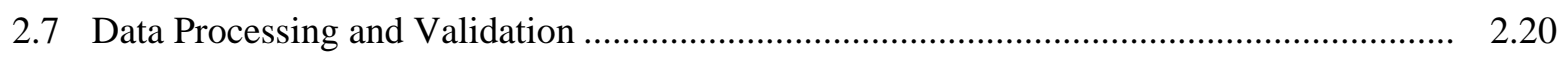

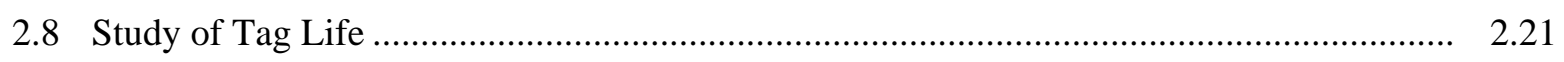

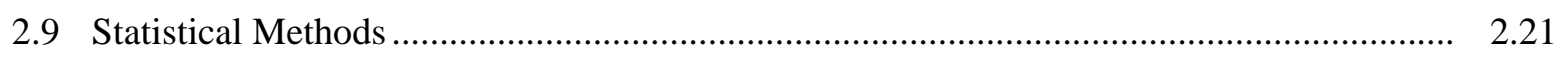

2.9.1 Defining Virtual Releases .............................................................................. 2.22

2.9.2 Estimation of Relative Survival for Shallow and Deep Deflector Bays.................... 2.23

2.9.3 Test of Spillway Survival Differences ................................................................. 2.25

2.9.4 Estimating Absolute Spillway Passage Survival ................................................. 2.26

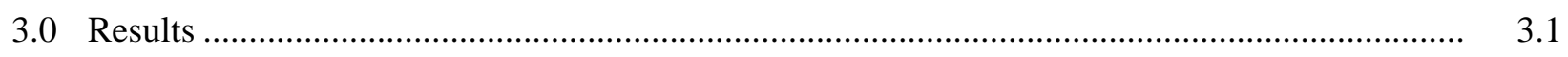

3.12007 Outmigration Conditions ................................................................................. 3.1 
3.1.1 Project Discharge, Temperature, and Tailrace Elevation ...................................... 3.1

3.1.2 Run Timing and Smolt Species Composition .................................................... 3.3

3.1.3 Fish Rejection Rates and Length Frequencies During Tagging ............................... 3.4

3.2 Detection of Dead Fish by Survival Arrays .................................................................... 3.6

3.3 Detection Performance of the Spillway Cabled Array ..................................................... 3.6

3.4 Detection Performance of Downstream Arrays ............................................................. 3.7

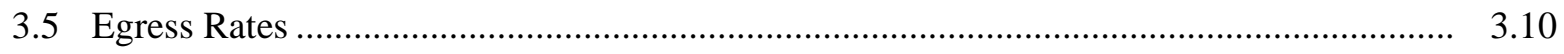

3.6 Detection and Survival of Yearling Chinook Salmon in Spring ...................................... 3.12

3.6.1 Tag-Life Study ............................................................................................. 3.12

3.6.2 Survival of Spillway-Passed Yearlings .............................................................. 3.13

3.6.3 Comparison of Deep Versus Shallow Flow Deflector Bays in Spring.................... 3.19

3.7 Detection and Survival of Subyearling Chinook Salmon in Summer ................................. 3.22

3.7.1 Tag-Life Study ............................................................................................... 3.22

3.7.2 Survival of Spillway-Passed Subyearlings ........................................................... 3.25

3.7.3 Comparison of Deep Versus Shallow Flow Deflector Bays in Summer.................. 3.29

3.8 Summary of Survival Results..................................................................................... 3.34

3.9 Tests of Survival-Model Assumptions …....................................................................... 3.34

3.9.1 Burnham Test Results ....................................................................................... 3.34

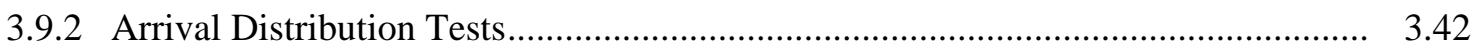

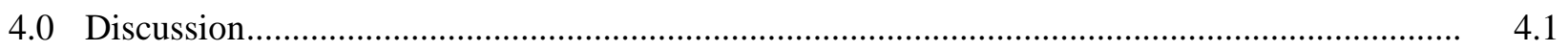

4.1 Environment and 2007 Outmigration Conditions .......................................................... 4.1

4.1.1 Project Discharge, Temperature, and Tailrace Elevation ...................................... 4.1

4.1.2 Run Timing and Smolt Species Composition ..................................................... 4.1

4.1.3 Length Frequencies ............................................................................................ 4.2

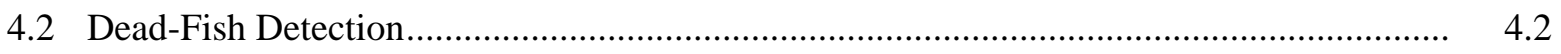

4.3 Detection Performance of the Spillway Cabled Array ....................................................... 4.4

4.4 Detection Performance of Downstream Arrays .............................................................. 4.5

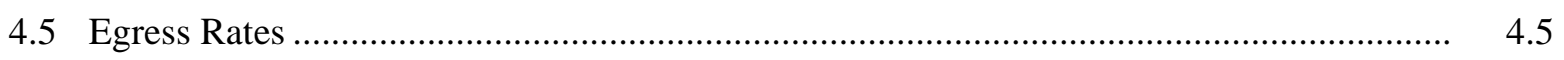

4.6 Detection and Survival of Yearling Chinook Salmon in Spring ..................................... 4.6

4.6.1 Tag-Life Study …............................................................................................ 4.6

4.6.2 Survival of Spillway-Passed Yearlings ............................................................. 4.7

4.6.3 Comparison of Deep Versus Shallow Flow Deflector Bays in Spring.................... 4.7

4.7 Detection and Survival of Subyearling Chinook Salmon in Summer ............................... 4.8

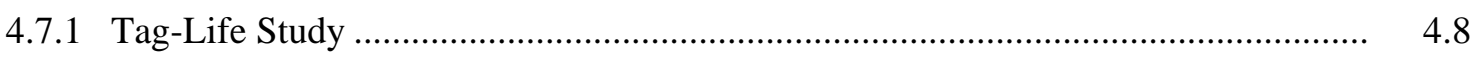

4.7.2 Survival of Spillway-Passed Subyearlings .......................................................... 4.8

4.7.3 Comparison of Deep Versus Shallow Flow Deflector Bays in Summer................... 4.8

4.8 Summary of 2007 Survival Results ..............................................................................

4.9 Tests of Survival-Model Assumptions …...................................................................... 4.10

4.9.1 Burnham Test Results ...................................................................................... 4.13 
4.9.2 Mixing of Spillway- and Tailrace-Released Fish.

5.0 Recommendations

6.0 References .

Appendix A - Tables of All Fish Tagging and Release Data.

A.1

Appendix B - Estimating the Additional Contribution of "Dead-Fish Releases" to the Overall Variance of Project Survival Estimates 


\section{Figures}

1.1 Study Area from Bonneville Dam Downstream to Camas, Washington...................................... 1.4

1.2 Aerial View of Bonneville Dam ................................................................................................

2.1 Sonic Concepts ${ }^{\circledR}$ JSATS Acoustic Micro-Transmitter ............................................................. 2.3

2.2 The ATS JSATS Acoustic Micro-Transmitter.......................................................................... 2.3

2.3 Insertion of a JSATS Acoustic Micro-Transmitter ....................................................................... 2.4

2.4 Transport Bucket and Insulated Holding Tanks .................................................................... 2.5

2.5 Plan View of the Bonneville Dam Spillway Showing Fish Release Sites and Locations of 16 Cabled Hydrophones and Beacons on Piers …........................................................................ 2.8

2.6 Side and Bottom View of a Node Top .................................................................................. 2.10

2.7 Array Locations in the Lower Columbia River in 2007 ..................................................... 2.12

2.8 Photograph of a Star Cluster of Four Hydrophones Being Lowered from the Roadway on the North Side of the Spillway Forebay to a Boat with a Crane ...................................................... 2.15

2.9 Photograph of a Hydrophone Baffled from the Direction of a Spill Gate ................................... 2.15

2.10 The Location of Autonomous Nodes in the Bonneville Dam Egress Array 9 km Downstream of the Dam

2.11 Locations of Autonomous Nodes in the Primary Array Near Rooster Rock State Park, and in the Secondary Array Near Reed Island.

2.12 Autonomous Node Locations in the Tertiary Array Near Lady Island and Camas, Washington approximately $42.4 \mathrm{~km}$ Downstream of Bonneville Dam

2.13 Node Rigging Without a 34-kg Anchor Shown from 0.3 to 1.8 m Below the Acoustic Release

2.14 Autonomous Node Retrieval.

2.15 Schematic of Spillway Survival Studies at Bonneville Dam in 2007, Showing Virtual Deep and Shallow Deflector Bay Releases and Corresponding Control Releases in the Tailrace.

3.1 Ten-Year Average Daily Project Discharge Versus 2007 Daily Project Discharge for the Bonneville Project.

3.2 Ten-Year Average Forebay Water Temperature Versus 2007 Water Temperature by Day at Bonneville Dam

3.3 Mean Tailrace Elevations in Meters Above MSL in Spring and Summer 2007

3.4 Smolt Monitoring Program Passage Index for March 1 through July 31, 2007, based on Data from the Bonneville Juvenile Monitoring Facility....

3.5 Length Frequency of 3000 Tagged and 1364 Untagged Run-of-River Yearling Chinook Salmon During Spring Tagging at the B2 JMF in 2007 .

3.6 Length Frequency of 2996 Tagged and 1301 Untagged Subyearling Chinook Salmon During Summer Tagging at the B2 JMF in 2007

3.7 Percent of Acoustic Tags in Spillway Forebay-Released Fish Detected and Decoded at Least Four Times in Two Minutes in Spring and Summer 2007

3.8 Percent of Acoustic Tag Detections on Autonomous Nodes Deployed in Arrays Downstream of Bonneville Dam in Spring and Summer. 
3.9 Frequency of Detections on Multiple Autonomous Nodes Within the Egress Array and Survival Arrays....

3.10 Detection Probabilities as a Function of Sampling Date and River Discharge.

3.11 Plot of Average Travel Time for Tagged Yearling Chinook Salmon Released in the Spillway Forebay and the Tailrace to Four Arrays of Autonomous Nodes Downstream.

3.12 Plot of Average Travel Time for Tagged Subyearling Chinook Salmon Released in the Spillway Forebay and the Tailrace to Four Arrays of Autonomous Nodes Downstream.

3.13 Estimated Acoustic Tag-Life Curves from the Tag-Life Study Run Concurrently with the Spring Chinook Survival Study at Bonneville Dam

3.14 Comparison of the Time of Activation of 2006 SC and 2007 SC Tags to the Time of Detection at Each of the Detection Arrays for Each Release Site ....

3.15 Relative Survival of Deep to Shallow Flow Deflector Bay-Passed Spring Chinook Salmon for the Bonneville Dam to BON1 Detection Array and BON1 to BON2 Detection Arrays ........

3.16 Estimated Acoustic-Tag Life of 2007 ATS Acoustic Tags in the Tag-Life Study that Ran Concurrently with the Summer Chinook Salmon Survival Study at Bonneville Dam

3.17 Estimated Acoustic-Tag Life of 2007 ATS Acoustic Tags from the Tag-Life Study and Percent of Released Tags in the Survival Study Detected at BON1

3.18 Estimated Acoustic-Tag Life of 2007 ATS Acoustic Tags from the Tag-Life Study and Percent of Released Tags in the Survival Study Detected at BON2.

3.19 Estimated Acoustic-Tag Life of 2007 ATS Acoustic Tags from the Tag-Life Study and Percent of Released Tags in the Survival Study Detected at BON2.

3.20 Summer Chinook Salmon Relative Survival Estimates by Trial for (a) Release to BON1 and (b) BON1 to BON2 Detection Arrays

3.21 Arrival Distributions at BON1, BON2, and BON3 Arrays for the Spring Chinook Salmon that Were Used in the Bonneville Dam Mid-Bay and End-Bay Spill Release Groups

3.22 Arrival Distributions at BON1, BON2, and BON3 Arrays for the Spring Chinook Salmon that Were Used in the Bonneville Dam Spillway and Tailrace Release Groups

3.23 Arrival Distributions at BON1, BON2, and BON3 Arrays for the Summer Chinook Salmon that Were Used in the Bonneville Dam Mid-Bay and End-Bay Spill Release Groups

3.24 Arrival Distributions at BON1, BON2, and BON3 Arrays for the Summer Chinook Salmon that Were Used in the Bonneville Dam Spillway and Tailrace Release Groups

4.1 Plot of Hour of Arrival Before, at, or After Midnight at Array BON1 for Fish Released in the Spillway Forebay and Tailrace in Spring and Summer 2007. 


\section{Tables}

2.1 Numbers of Tagged and Released Yearling Chinook Salmon in Spring 2007 ........................... 2.6

2.2 Numbers of Tagged and Released Subyearling Chinook Salmon in Summer 2007................... 2.7

2.3 Dilution of Poly-Aqua Used in Surgical Procedures .............................................................. 2.9

2.4 Global Positioning System Coordinates of Autonomous Nodes Deployed in 2007................... 2.13

2.5 Global Positioning System Coordinates of Cabled Hydrophones Deployed in the Forebay of the Bonneville Dam Spillway in 2007

2.6 Detection Histories and Expected Probabilities of Occurrences for Upstream $\left(R_{1}\right)$ and Downstream $\left(R_{2}\right)$ Releases in the Presence of Tag Failure......

3.1 Detection Sequence for a Dead Tagged Fish Released on May 25 in the Spillway Forebay .....

3.2 Detection Histories for All Spillway-Passed Spring Chinook Salmon Tagged with the SC 2006 Acoustic Tags

3.3 Detection Histories for All Spillway-Passed Spring Chinook Salmon Tagged with the SC 2007 Acoustic Tags

3.4 Detection Histories for All Tailrace-Released Spring Chinook Salmon Tagged with the SC 2006 Acoustic Tags

3.5 Detection Histories for All Tailrace-Released Spring Chinook Salmon Tagged with the SC 2007 Acoustic Tags

3.6 Cormack-Jolly-Seber Survival and Detection Probabilities for Spillway-Forebay-Released Yearling Chinook Salmon Bearing SC 2006 Tags and Traveling from Just Below Bonneville Dam to Array BON1 and from Arrays BON1 to BON2 by Virtual Release Date .

3.7 Cormack-Jolly-Seber Survival and Detection Probabilities, Adjusted for Estimated Tag Life, for Spillway-Forebay-Released Yearling Chinook Salmon Bearing SC 2007 Tags and Traveling from Bonneville Dam to Array BON1 and from Arrays BON1 to BON2 by Virtual Release Date

3.8 Cormack-Jolly-Seber Survival and Detection Probabilities for Tailrace-Released Yearling Chinook Salmon Bearing SC 2006 Tags and Traveling from Just Below Bonneville Dam to Array BON1 and from Arrays BON1 to BON2 by Virtual Release Date

3.9 Cormack-Jolly-Seber Survival and Detection Probabilities, Adjusted for Estimated Tag Life, for Tailrace-Released Yearling Chinook Salmon Bearing SC 2007 Tags and Traveling from Just Below Bonneville Dam to Array BON1 and from Arrays BON1 to BON2 by Virtual Release Date

3.10 Estimated Paired-Release Survival and Standard Errors for Spillway-Passed Yearling Chinook Salmon Bearing SC 2006 Acoustic Tags .

3.11 Estimated Paired-Release Survival and Standard Errors, Adjusted for Estimated Tag Life, for Spillway-Passed Yearling Chinook Salmon Bearing SC 2007 Acoustic Tags ....

3.12 Shallow Flow Deflector Spring Chinook Salmon Detection Histories at BON1, BON2, and BON3.....

3.13 Deep Flow Deflector Spring Chinook Salmon Detection Histories at BON1, BON2, and BON3.

3.14 Single-Release Survival and Detection Estimates for Yearling Chinook Salmon Passing Bays with Shallow Flow Deflectors and Traveling from Bonneville Dam to Array BON1 and from Array BON1 to BON2 by Virtual Release Date 
3.15 Single-Release Survival and Detection Estimates for Yearling Chinook Salmon Passing Bays with Deep Flow Deflectors and Traveling from Bonneville Dam to Array BON1 and from Array BON1 to BON2 by Virtual Release Date.

3.16 Estimated Relative Survival by Release Pair.

3.17 Detection Histories on Three Survival Arrays for Chinook Salmon Smolts Released in the Spillway Forebay in Summer.

3.18 Detection Histories on Three Survival Arrays for Chinook Salmon Smolts Released in the Tailrace on the Same Days as Forebay Releases in Summer

3.19 Detection Histories on Three Survival Arrays for Chinook Salmon Smolts Released in the Tailrace on Days Without Forebay Releases in Summer

3.20 Cormack-Jolly-Seber Survival and Detection Probabilities for Spillway-Forebay-Released Subyearling Chinook Salmon Traveling from Bonneville Dam to Array BON1 and from Arrays BON1 to BON2 by Virtual Release Date

3.21 Cormack-Jolly-Seber Survival and Detection Probabilities for Tailrace-Released Subyearling Chinook Salmon Traveling from Bonneville Dam to Array BON1 and from Arrays BON1 to BON2 by Virtual Release Date

3.22 Shallow Flow Deflector Summer Chinook Salmon Detection Histories at BON1, BON2, and BON3.

3.23 Deep Flow Deflector Summer Chinook Salmon Detection Histories at BON1, BON2, and BON3

3.24 Single-Release Estimates of Survival and Detection Probabilities for Subyearling Chinook Salmon that Passed Through Bays with Shallow Flow Deflectors Based on Detection Histories for Arrays BON1, BON2, and BON3.

3.25 Single-Release Estimates of Survival and Detection Probabilities for Subyearling Chinook Salmon that Passed Through Bays with Deep Flow Deflectors Based on Detection Histories for Arrays BON1, BON2, and BON3.

3.26 Relative Survival by Release Pair for the First and Second Reaches

3.27 Summary of Absolute and Relative Survival at Bonneville Spillway in 2007, Standard Errors, and 95\% Confidence Intervals ....

3.28 Results of Burnham et al. Tests 1.T2 and 1.T3 for Equal Detection and Survival Probabilities at Downriver Detection Sites for the Spring Chinook Salmon that Were Used in the Bonneville Dam Mid-Bay and End-Bay Spill Release Groups

3.29 Results of Burnham et al. Tests 2 and 3 for Goodness-of-Fit to the Single-Release-Recapture Assumptions for the Spring Chinook Salmon that Were Used in the Bonneville Dam MidBay and End-Bay Spill Release Groups

3.30 Results of Burnham et al. Tests 1.T2 and 1.T3 for Equal Detection and Survival Probabilities at Downriver Detection Sites for the Spring Chinook Salmon that Were Used in the Bonneville Dam Spillway and Tailrace Release Groups

3.31 Results of Burnham et al. Tests 2 and 3 for Goodness-of-Fit to the Single-Release-Recapture Assumptions for the Spring Chinook Salmon that Were Used in the Bonneville Dam Pooled Spillway and Tailrace Release Groups

3.32 Results of Burnham et al. Tests 1.T2 and 1.T3 for Equal Detection and Survival Probabilities at Downriver Detection Sites for the Summer Chinook Salmon that Were Used in the Bonneville Dam Mid-Bay and End-Bay Spill Release Groups . 
3.33 Results of Burnham et al. Tests 2 and 3 for Goodness-of-Fit to the Single-Release-Recapture Assumptions for the Summer Chinook Salmon that Were Used in the Bonneville Dam MidBay and End-Bay Spill Release Groups

3.34 Results of Burnham et al. Tests 1.T2 and 1.T3 for Equal Detection and Survival Probabilities at Downriver Detection Sites for the Summer Chinook Salmon that Were Used in the Bonneville Dam Spillway and Tailrace Release Groups

3.35 Results of Burnham et al. Tests 2 and 3 for Goodness-of-Fit to the Single-Release-Recapture Assumptions for the Summer Chinook Salmon that were Used in the Bonneville Dam Spillway and Tailrace Release Groups

4.1 Average Travel Times from Bonneville Tailrace to the Primary Array and from the Primary to the Secondary Array in 2006 and 2007

4.2 Survival Estimates from Previous Studies and this 2007 Study 


\subsection{Introduction}

In continually seeking to improve the conditions juvenile anadromous fish experience when passing through the dams that it operates on the Columbia River, the U.S. Army Corps of Engineers (USACE) Portland District (CENWP) has funded numerous evaluations of fish passage and survival. In 2007, the CENWP asked Pacific Northwest National Laboratory (PNNL) ${ }^{1}$ to conduct an acoustic telemetry study to estimate the survival of juvenile Chinook salmon passing the spillway at Bonneville Dam.

\subsection{Study Overview}

Under the 2007 acoustic telemetry study, fish longer than $95 \mathrm{~mm}$ were surgically implanted with Juvenile Acoustic Telemetry System (JSATS) and passive integrated transponder (PIT) tags and held overnight prior to their release. They were released between 1400 and 1700 hours on 16 days in spring and 14 days in summer by the PNNL team in the spillway forebay and by a National Oceanic and Atmospheric Administration (NOAA) Fisheries team in the tailrace to create treatment- and referencerelease groups, respectively. Some treatment fish were detected on spillway hydrophones and assigned a bay of passage based upon the location of the last of at least four detections of implanted acoustic tags. Detections of PIT tags in Powerhouse 2 (B2), the Corner Collector (B2CC), and the B2 Juvenile Bypass System (B2 JBS) were used to assign non-spillway routes of passage. Routes of spillway passage included end bays 1 through 3 and 16 through 18 with deep spill deflectors (2.134 m above mean sea level [MSL]), and middle bays 4 through 15 with shallow flow deflectors (4.267 m above MSL). Some fish were released in the spillway forebay above the dam to create treatment release groups that would pass through the spillway, and other fish were released $2 \mathrm{~km}$ downstream of the spillway in the tailrace to create reference-release groups that did not pass through the spillway. Reference releases in the tailrace began about 1 hour after the start of treatment releases in the forebay so that both groups would mix and pass through the common downstream tailwater about the same time of day. The common tailwater for our survival estimates was from the tailrace-release site $2 \mathrm{~km}$ downstream of the dam to the first or second of three tag-detection arrays located downstream of the dam. An array is a group of autonomous underwater receivers (nodes) deployed to listen for acoustic tags passing through a cross section of the river. We had three survival arrays located approximately 25, 34.4, and $42.4 \mathrm{~km}$ downstream of the dam. Treatment fish were exposed to passage through $<75 \mathrm{~m}$ of spillway forebay, spill bays, and $2 \mathrm{~km}$ of tailrace that the reference-release groups avoided. Single-release estimates included survival from the point of release to the primary detection array or from the primary array to the secondary array and included losses of fish in the common tailwater. Paired-release survival estimates for spillway-passed fish to the tailrace-release site were calculated as the ratio of the single-release survival of treatmentrelease groups to the single-release survival of reference-release groups.

\subsection{Background}

Several factors govern the discharge and pattern of spill at Bonneville Dam, including total dissolved gas (TDG) limitations and effects on adult and juvenile salmonid passage. The Biological Opinions (BiOps) for the Federal Columbia River Power System (FCRPS) issued in 2000 and 2004 called for

${ }^{1}$ PNNL is operated by Battelle Memorial Institute for the U.S. Department of Energy under Contract DE-AC0576RL01830. 
agencies to continue to provide spill for juvenile salmonid passage, because "spill is the option that provides dam passage with the least mortality.” The States of Oregon and Washington granted waterquality waivers to allow TDG levels in the tailwater to rise above $110 \%$ of saturation (state water-quality standards) to $120 \%$ of saturation over a maximum 12-hour daily average (a gas cap). Before the construction of additional spillway flow deflectors in 2002, the spillway at Bonneville Dam was recognized as being one of the biggest TDG producers on the Columbia River. During winter 20012002, six new spillway flow deflectors were constructed at Bonneville Dam to reduce the production of TDG during spillway discharge. The new flow deflectors in spill bays 1 through 3 and 16 through 18 were placed $2.134 \mathrm{~m}$ deeper than the existing flow deflectors located in spill bays 4 through 15 . A new spill pattern was implemented in conjunction with the addition of the new flow deflectors. A study was conducted throughout the 2002 spill season to determine the TDG exchange characteristics of spill operations at Bonneville Dam (Schneider et al. 2003). The study found that the addition of six new flow deflectors and the corresponding change in spill pattern significantly reduced the TDG saturation when compared to similar spill rates observed prior to the 2002 spill season. However, the degree of improvement over pre-2002 conditions declined with increasing discharge. The estimated reduction in TDG saturation for a spill discharge of $75,000 \mathrm{cfs}$ was $10 \%$ of saturation. For low tailwater elevations, ranging from 3.1 to $4.18 \mathrm{~m}$ above MSL, the new flow deflectors generated considerably lower TDG pressures than the old deflectors.

In terms of biological effects, Johnson and Dawley (1974) found that fall Chinook salmon passing bays without flow deflectors had higher survival (95.8\%) than subyearlings passing bays with flow deflectors (86.8\%). The effects of the two types of spillway deflectors have been evaluated in direct survival studies using balloon tags (Normandeau et al. 1996, 2003) and indirect survival studies using radiotelemetry (Counihan et al. 2006a, 2006b). In both cases, trends were apparent, although usually not significant, and further evaluations were needed to identify effects and confirm results. The 2002 balloon-tag data suggested that when tailwater surface elevations were low, injury increased and survival decreased. The survivals of fish released at bays with deflectors at the 4.267-m elevation were compared with survivals of fish released at bays with deflectors at the 2.134-m elevation, but estimates of precision were low (Normandeau et al. 2003). Radiotelemetry survival studies conducted in 2004 and 2005 showed a trend of decreasing survival with decreasing spill volumes, and bays equipped with the shallow flow deflectors usually had lower survival than bays with the deep flow deflectors. Most results were not statistically significant, but there was some consistency in trends. One operational explanation for reduced survival was a new spill pattern that used smaller gate openings and more spill bays for the 75,000-cfs day spill. In 2006, a total survival evaluation looked at 100,000-cfs spill for 24 hours/day in spring and a modified BiOp spill with larger gate openings in summer. Unfortunately, the effects of spill condition were confounded by a typical decline in the survival of subyearling Chinook salmon as summer progressed (Ploskey et al. 2007b). The need to better quantify the effects of the two types of spill deflectors on juvenile survival prompted this study.

\subsection{Study Objectives and Tasks}

The primary objective of the acoustic telemetry study reported here was to conduct spring and summer spillway survival studies, each with sufficient statistical power to test the null hypothesis that the survival of juvenile Chinook salmon passing through spill bays with deep flow deflectors-at an

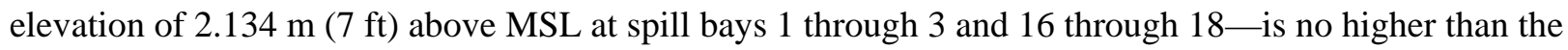


survival of fish passing bays with shallow flow deflectors (at $4.267 \mathrm{~m} \mathrm{[14} \mathrm{ft]} \mathrm{above} \mathrm{MSL} \mathrm{at} \mathrm{spill} \mathrm{bays}$ 4 through 15). We also estimated survival for juvenile Chinook salmon passing the entire spillway. Tasks undertaken to accomplish the objectives included the following:

1. Surgically implant 3000 yearling Chinook salmon (YC) in spring and 2999 subyearlings (SYC) in summer with JSATS acoustic and PIT tags and release them in the spillway forebay at Bonneville Dam. These treatment releases began at about 1400 hours and ended by 1700 hours on each of 16 days in spring and 14 days in summer.

2. Surgically implant 1040 YC and 1040 SYC with JSATS and PIT tags to be released by a NOAA Fisheries team into the tailrace of Bonneville Dam as reference release groups between 1500 and 1800 hours on the same days that treatment fish were released. The start of tailrace releases was delayed 1 hour after the start of forebay releases so that the first releases of treatment fish would have time to pass the spillway and tailrace and then mix with the first reference releases. There also were other releases of YC and SYC in the tailrace for a 2007 Estuary Survival Study, and some of these were not paired with the daily releases of treatment fish described above.

3. Deploy and maintain hydrophones on 16 of 19 spillway piers and in star configurations at five forebay locations to detect the passage of tagged fish. The hydrophone detections were used to assign a bay of passage for fish based upon the location of the last of at least four detections within 120 seconds. Fish released into the spillway forebay and not detected by PIT-tag detectors at B2, B2CC, and B2 JBS were assumed to have passed the spillway, and these fish were used to estimate survival of fish passing the spillway each day and season.

4. Deploy and maintain a primary tailwater survival array between Cape Horn, Washington, and Rooster Rock State Park, Oregon (25 km downstream of Bonneville Dam), a secondary array at Reed Island (34.4 km downstream), and a tertiary array at Lady Island (42.4 km downstream). Detections on these arrays were used to complete detection histories for route-specific survival estimates using single- and paired-release survival models.

5. Estimate distribution statistics associated with the time required for passage from the spillway forebay.

6. Estimate survival by route of passage based upon detection histories of treatment and reference fish at the primary, secondary, and tertiary tailwater arrays, using paired-release survival models. Routes were pooled by type (e.g., spill bays with deflectors at $2.134 \mathrm{~m}$ elevation above MSL; spill bays 1 through 3 and 16 through 18) and bays with deflectors at 4.267 m elevation above MSL (spill bays 4 through 15). All survival estimates were accompanied by an estimate of precision (a standard error [SE] or a one-half 95\% confidence interval [CI]).

7. Test the null hypothesis that the survival of YC and SYC passing through spill bays with deep flow deflectors (spill bays 1 through 3 and 16 through 18) was no higher than the survival of fish passing bays with shallow deflectors (spill bays 4 through 15 ).

8. Compare survival results with previous estimates based upon radiotelemetry studies. 


\subsection{Site Descriptions}

The study area covered about $45 \mathrm{~km}$ of the lower Columbia River from Bonneville Dam to Lady Island near Camas, Washington (Figure 1.1). Fish were released by boat in the spillway forebay and in the tailrace adjacent to a USACE boat launch. Cabled underwater hydrophones were deployed on 16 of 19 spillway piers and in the spillway forebay to detect the passage of tagged fish and assign the last detections of tags to the bay where fish passed the spillway. A tailrace egress array consisting of four autonomous acoustic telemetry receivers (hereafter referred to as nodes) was deployed about $9 \mathrm{~km}$ downstream adjacent to Skamania Landing, Washington. Three survival arrays also were deployed. A primary array with six autonomous nodes was located near Cape Horn, Washington, Sand Island, and Rooster Rock State Park, Oregon. A secondary array with five autonomous nodes was located near Reed Island, and detections by three backwater hydrophones located behind Chatham and Gary islands were included as secondary array detections. The backwater hydrophones were installed for a Bonneville Power Administration (BPA) study of the old Sandy River Delta. The tertiary survival array consisted of four hydrophones located across the Columbia River adjacent to Lady Island and one located north of the island.

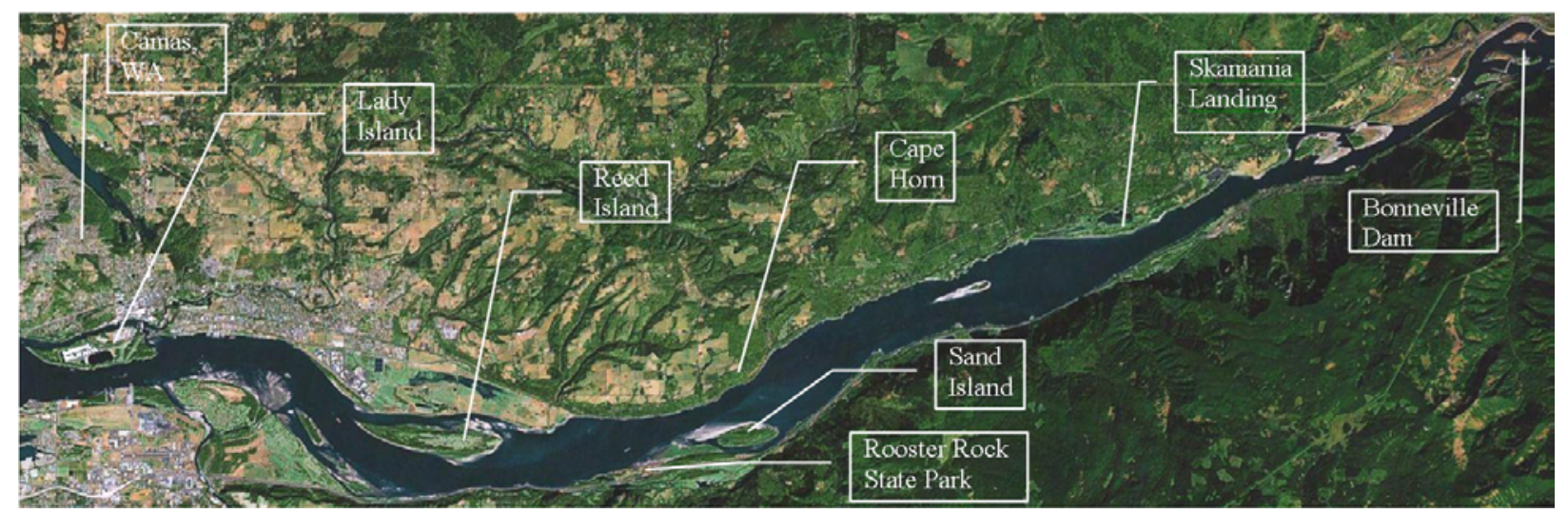

Figure 1.1. Study Area from Bonneville Dam Downstream to Camas, Washington. (The background image was derived from Google Maps.)

At the upstream end of the study area, Bonneville Lock and Dam consist of several structures that together span the Columbia River between Oregon and Washington near river kilometer (rkm) 234.3, about 64 km east of Portland, Oregon (Figure 1.2). From the Oregon shore north toward Washington, Bonneville Dam is composed of a navigation lock, 10-turbine Powerhouse 1 (B1), Bradford Island, an 18bay spillway, Cascades Island, and 8-turbine B2. The spillway and B1 were constructed between 1933 and 1937 without specific regard for protecting juvenile salmonids migrating downstream. Construction of B2 began in 1974 and was completed in 1982. The CENWP operates Bonneville Dam for hydroelectric power generation for the BPA and the Bonneville Lock for navigation by passing river traffic. 


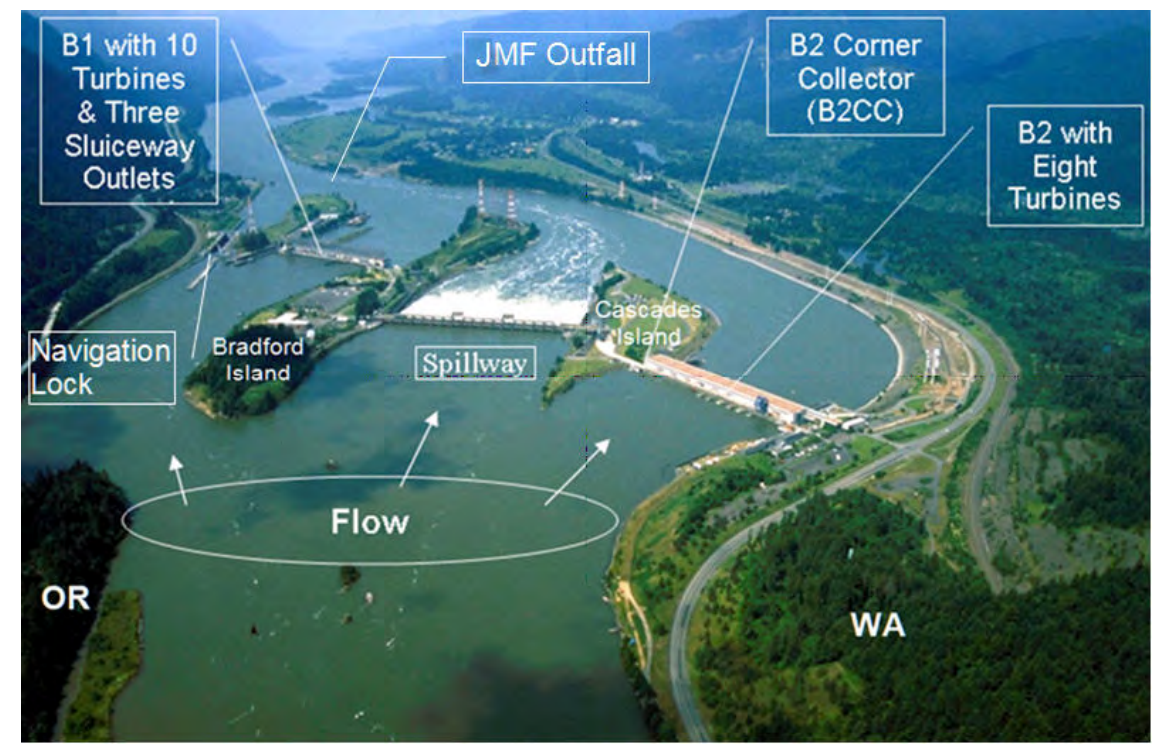

Figure 1.2. Aerial View of Bonneville Dam. JMF = Juvenile Monitoring Facility; B1 = Powerhouse 1; B2 $=$ Powerhouse 2

\subsection{Report Contents and Organization}

The ensuing sections of this report present the materials and methods used in conducting the acoustic telemetry survival study at the Bonneville spillway (Section 2.0) and the study results (Section 3.0). Section 4.0 describes the environment and 2007 outmigration conditions and discusses the results of the study, including dead-fish detection, detection performance, egress rates, detection and survival of yearling Chinook salmon in spring and subyearling Chinook salmon in summer, and tests of survivalmodel assumptions. Recommendations are provided in Section 5.0, followed by a reference list in Section 6.0. Finally, Appendixes A and B, respectively, contain tables of fish tagging and release data and a description of the method for estimating the additional contribution of dead-fish releases to the overall variance of project survival estimates. 



\subsection{Materials and Methods}

Estimating the survival of juvenile Chinook salmon passing the spillway at Bonneville Dam involved collecting, tagging, releasing, and detecting fish, while taking care to minimize the impacts of handling the fish. The associated materials and methods and data collection, processing, and validation methods are described in the following sections, along with a tag-life study and statistical methods.

\subsection{Fish Collection}

Fish were collected for this study in accordance with established permitting requirements using the sampling methods at the selected site, as described below.

\subsubsection{Site Description}

Outmigrating yearling and subyearling Chinook salmon were collected and tagged at the Hamilton Island Juvenile Monitoring Facility (JMF; Figure 1.2), which is located at the downstream end of the B2 JBS. Juvenile salmonids begin moving through the B2 JBS after they are screened from the upper third of 1 of 24 B2 turbine intakes and diverted into a gatewell slot located above each intake. From the gatewell slot, most smolts pass through a 0.305 -m-diameter orifice into a collection channel that runs through B2 toward the Washington shore. After dewatering to reduce JBS discharge, fish and remaining flow pass into a 1.22-m-diameter conveyance pipe that runs about $3.2 \mathrm{~km}$ from B2 to the JMF.

\subsubsection{Federal and State Permitting}

Records were kept on all smolts handled and collected (both target and non-target species) for permit accounting. Collections were conducted in conjunction with routine sampling at the JMF to minimize the impacts of handling. Surgical candidates collected from routine JMF target sample sizes were accounted for under permits issued to the JMF. Additional fish required to meet research needs (beyond JMF goals) were accounted for under separate federal and state permits.

A federal scientific take permit (SS-07 PNNL-40) was authorized for this study by the NOAA Fisheries Hydropower Division's FCRPS Branch and administered by the NOAA. This permit was authorized under the 2004 FCRPS BiOp.

A state scientific collection permit (\#07-191) was issued by the Washington Department of Fish and Wildlife for this study.

A transport permit was issued by the Oregon Department of Fish and Wildlife for trucking and transferring fish to boats located at the south side of the spillway for release into the spillway forebay. This permit was authorized under the 2004 FCRPS BiOp after consideration of the federal take permit.

All permit requirements and guidelines were met. Several amendments were made throughout the season to reflect variances in the numbers of in-stream migrants. Collection and release data were reported to all required agencies. 


\subsubsection{Sampling Methods}

Pacific States Marine Fisheries Commission (PSMFC) staff diverted fish from the JBS using detailed methods described by Martinson et al. (2006). Small batches of about 250 fish were anesthetized using a tricaine methanesulfonate (MS-222) solution prepared at a concentration of $44 \mathrm{mg} / \mathrm{l}$. Once fish were in the examination trough, MS-222 was added as necessary to maintain induction.

PNNL staff evaluated the candidate fish using the following specific acceptance and rejection criteria:

\section{Accept if the fish}

- adipose-fin is clipped or unclipped

- $\quad$ length is $>95 \mathrm{~mm}$.

\section{Reject if the fish}

- is a non-target species

- exhibits descaling greater than $20 \%$ on any one side

- shows signs of prior surgery (for instance: radio tags, sutures, or PIT-tag scars)

- indicates positive readings when put through a PIT-tag reader

- has physical injuries, such as to the head (injury on the head or in the eye); operculum damage (torn or folded); popeye; body injury; or fin hemorrhage

- $\quad$ shows evidence of infections or parasites, such as fungus (infection on the body surface); Bacterial Kidney Disease; Columnaris (yellow rimmed sores, ulcers, or open lesions on the body or fins); or trematodes (subdermal parasites)

- shows signs of predation, such as bird strikes or injuries inflicted by other fish or mammals that result in punctures or abrasions.

Non-target and rejected fish were released to the river through the JMF holding system after a 30minute recovery period. Accepted fish were counted into transfer buckets containing fresh river water, and moved to one of two, 511-l pre-surgical holding tanks. Fish were held in the tanks for 24 hours so that guts contents would be evacuated before surgery.

\subsection{Fish Tagging}

Acoustic tags were surgically implanted in the fish, which were held for recovery as described here, prior to their being released.

\subsubsection{JSATS Acoustic Micro-Transmitter}

The acoustic tags used in this study and in the Estuary Survival Study, which released fish into the Bonneville Dam tailrace, had a ping rate of 1 pulse every 5 seconds. Each pulse from a JSATS tag contains a complex phase-encoded signal that uniquely identifies the transmitting tag. Studies conducted on the Snake River used JSATS tags that transmitted once every 10 seconds. 
The acoustic tag used in spring was manufactured by Sonic Concepts ${ }^{\circledR}$ (SC) (Figure 2.1). It weighed $0.65 \mathrm{~g}$ in air, $0.37 \mathrm{~g}$ in water, and was $17 \mathrm{~mm}$ long and $5.5 \mathrm{~mm}$ wide. Prior to being inserted into the fish, each tag had to be activated using a dissecting microscope to solder battery leads. Activation was done by Cascade Aquatics, Inc. The time lapse from the time of activation until surgical implantation ranged from 1 to 6 days.

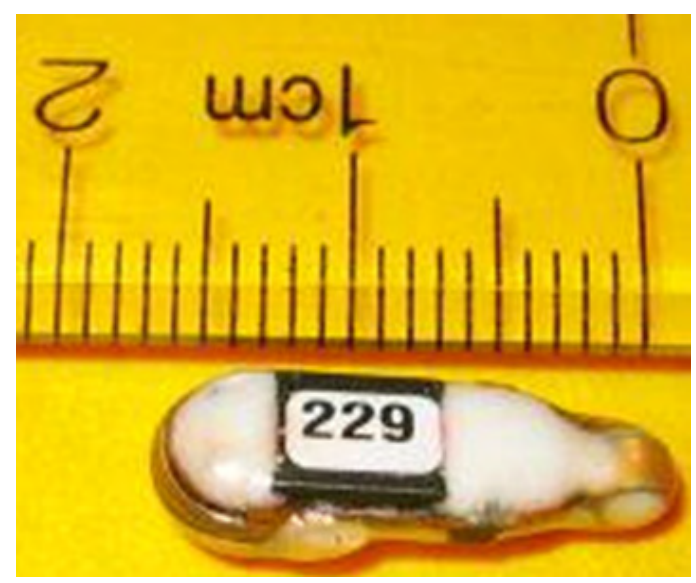

Figure 2.1. Sonic Concepts ${ }^{\circledR}$ JSATS Acoustic Micro-Transmitter

The acoustic tag used in summer was manufactured by Advanced Telemetry Systems ${ }^{\circledR}$ (ATS). The ATS transmitters were (mean \pm standard deviation) $5.6 \pm 0.2 \mathrm{~mm}$ wide, $15.8 \pm 0.2 \mathrm{~mm}$ long, and $4.2 \pm 0.2$ $\mathrm{mm}$ in height. Transmitters had a mean weight in air of $0.61 \pm 0.01 \mathrm{~g}$ (Figure 2.2). Prior to being inserted into the fish, each tag was activated by Cascade Aquatics, Inc., using an activation dish that uses acoustic signals to activate or deactivate tags.

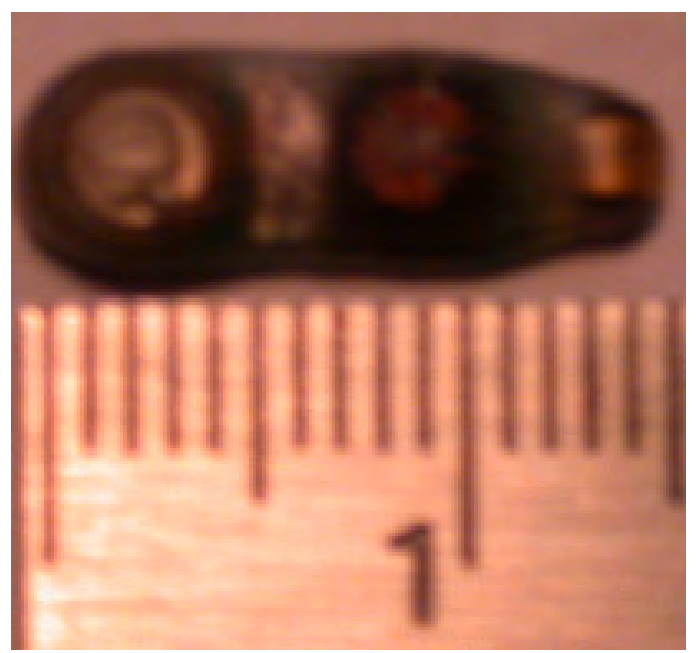

Figure 2.2. The ATS JSATS Acoustic Micro-Transmitter

\subsubsection{Tagging Procedure}

A team of 11 people participated in the tagging process to reduce the handling time from netting to post-surgery recovery. Fish were netted in small groups from 511-l holding tanks and anesthetized in a 18.93-1 "knockdown" bucket with fresh river water and MS-222 at a concentration between 80 and 
$100 \mathrm{mg} / \mathrm{l}$. Once a fish lost equilibrium, it was transferred to a processing table in a small container of knockdown solution. Each fish was measured (fork length $\pm 1 \mathrm{~mm}$ ), weighed ( $\pm 0.1 \mathrm{~g}$ ), and returned to the small transfer container along with an assigned PIT tag and an activated acoustic tag. Another biologist entered the fork length, weight, and tag numbers in Teknologic TekReader software, which input the data to an Excel database. The data entry system minimizes errors by reading PIT-tag numbers with a PIT-tag reader and acoustic tag codes with a mobile hydrophone system. A digitizing board and scale with a serial output cable facilitated accurate measurement of fish lengths and weights, respectively, and results were automatically fed into text files on a computer. The transfer container, fish, and tags were assigned a recovery bucket number and handed to a surgeon for tag implantation.

During surgery (Figure 2.3), each fish was placed ventral side up and a gravity-fed anesthesia supply line was placed into its mouth. The dilution of this "maintenance” line was $40 \mathrm{mg} / \mathrm{l}$. A 6- to 8-mm incision, using a \#10 or \#15 stainless-steel surgical blade, was made ventrally, $3 \mathrm{~mm}$ from and parallel to the mid-ventral line and equidistant from the pelvic girdle and pectoral fin. A PIT tag was inserted followed by an acoustic tag. Both tags were inserted toward the anterior end of the fish. Two interrupted sutures were made using 5-0 violet monofilament suture with a RB-1 needle. With the incision closed, fish were routed via a 10.16-cm polyvinyl chloride (PVC) pipe to a numbered recovery bucket.

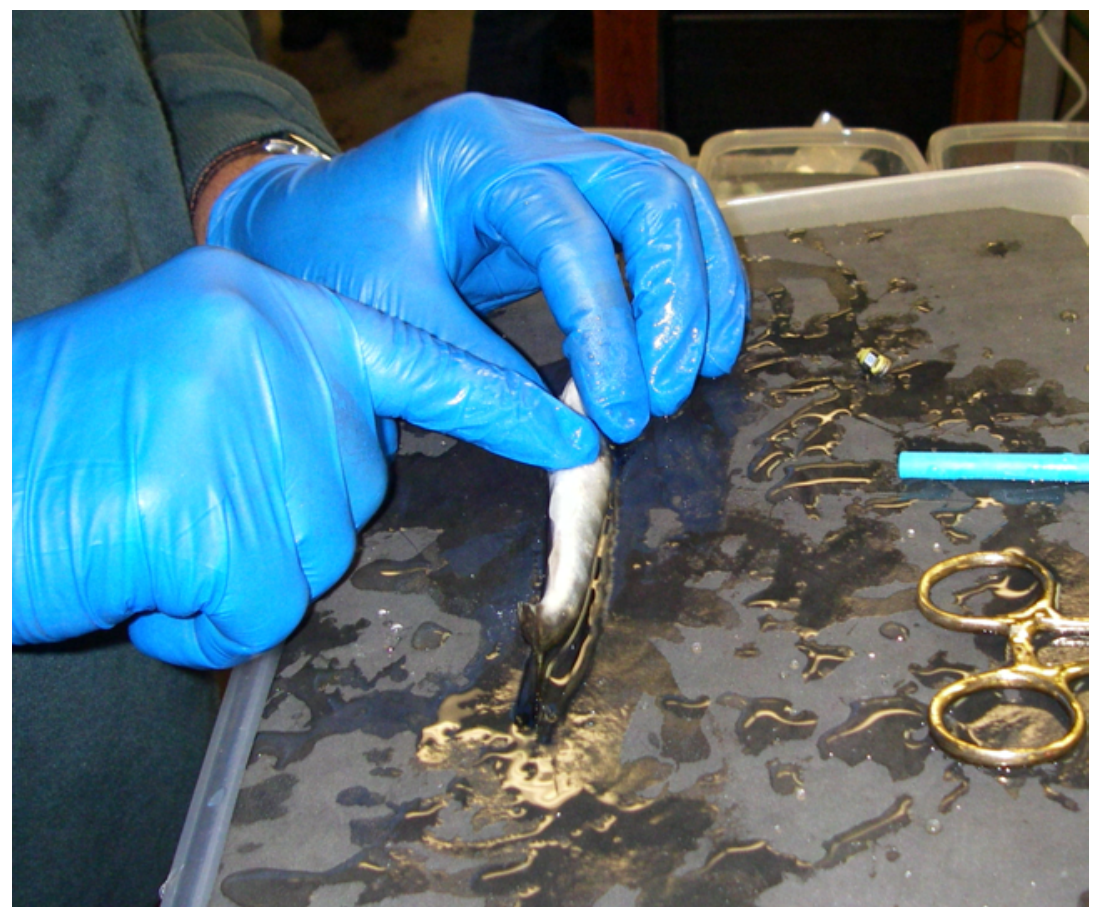

Figure 2.3. Insertion of a JSATS Acoustic Micro-Transmitter

\subsubsection{Recovery and Holding}

Each 18.9-l dark recovery and/or transport bucket (Figure 2.4) held 5 to 10 fish depending on the number of fish to be released at each site. Buckets were supplied with oxygen until fish recovered from the anesthesia. The buckets were then carried to and submerged in a larger holding tank with a continuous supply of river water (Figure 2.4). Fish were held and monitored for 24 hours prior to their release. The large holding tank was insulated to keep the water temperature within acceptable limits. 
A sensor for monitoring water level, temperature, and dissolved oxygen was installed and set up to automatically telephone staff if water-quality conditions were undesirable for fish. Alert limits were set to a maximum of $21.7^{\circ} \mathrm{C}$ and a minimum of $7 \mathrm{mg} / \mathrm{l}$ of oxygen.
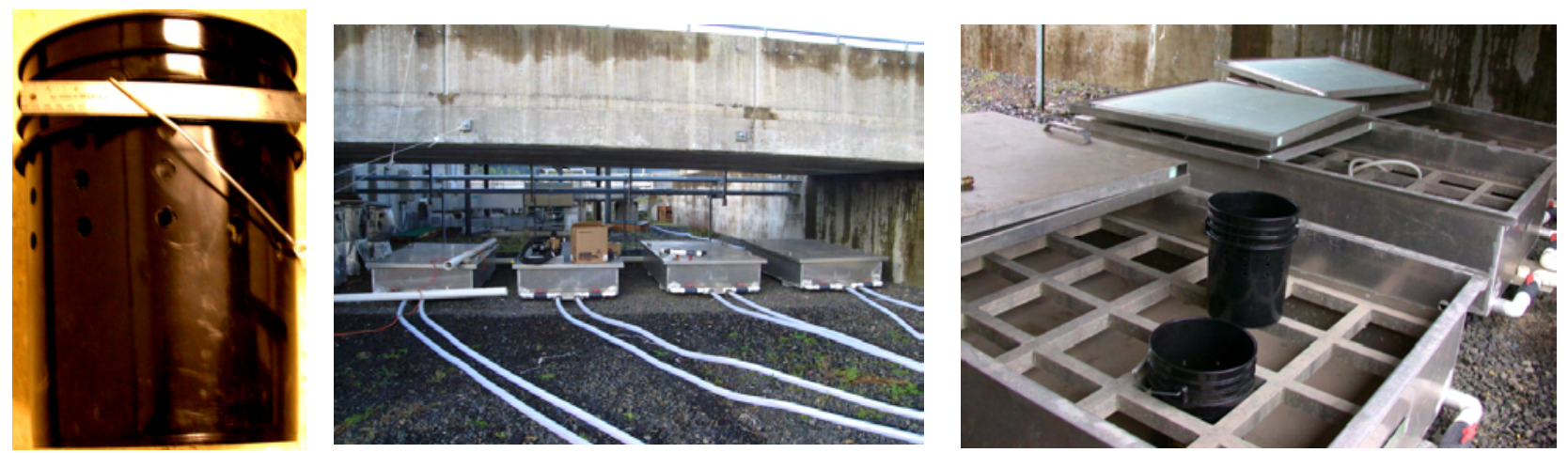

Figure 2.4. Transport Bucket (left) and Insulated Holding Tanks (middle and right). The upper half of the transport bucket had 0.95-cm-diameter holes to allow river water to flow through, and the bottom half lacked holes to provide a water-and-fish sanctuary whenever buckets were moved from one holding tank to another. Holding tanks were plumbed to allow flow-through river water around and through 32 transport buckets, which were stabilized by a rectangular aluminum grid (right picture).

\subsection{Transport and Release}

Fish were transported and released as described in the following sections.

To transport fish from the JMF to the release location in the spillway forebay of the Bonneville Dam, we secured 681- and 265-l Bonar insulated totes in the bed of a pickup truck. The 681-l tote held ten 18.9-l transport buckets and the 265-l tote held four buckets. Totes had snug-fitting lids and some extra space to accommodate a wood-frame separator so that ice could be added for cooling on hot days. A network of valves and plastic tubing was attached to oxygen $\left(\mathrm{O}_{2}\right)$ tanks for delivering oxygen to individual fish buckets from $2200 \mathrm{psi}_{2}$ tanks in the truck bed. Fish buckets were removed from the post-surgery holding tank, loaded into totes in the pickup truck, supplied with oxygen lines, and checked to make certain that each bucket was receiving $\mathrm{O}_{2}$. Total transport time was no longer than 15 minutes.

All survival estimates in this study were based on fish released in the spillway forebay (treatment fish) or in the tailrace (reference fish). Placing treatment fish directly into the forebay deviates from guidelines developed for estimating dam survival (Peven et al. 2005), but the goal in this study was to compare survival of fish passing through two types of spill bays. The CENWP opted for direct releases to reduce the number of fish that would have to be tagged and released by 50 percent. Many more fish would have been required to deliver the same numbers to the spillway if releases had been done below The Dalles Dam upstream, because Bonneville Dam has a spillway passage efficiency that averages about $41 \%$ and ranges from 16 to 65\% (Ploskey et al. 2007a). Fish released by other JSATS studies conducted on the Snake River upstream of Bonneville Dam were detected on autonomous and cabled hydrophones deployed in this study, but we did not use the detections to make survival estimates because diminished survival likely resulting from tag effects was evident by the time the released fish reached McNary Dam (Richard Brown, Personal Communication, 2007). Numbers of fish tagged by this study are listed in Table 2.1 and Table 2.2. 
Table 2.1. Numbers of Tagged and Released Yearling Chinook Salmon in Spring 2007. The number released included the number listed in the Mortalities column.

\begin{tabular}{|c|c|c|c|c|c|c|}
\hline Date & Age Class & $\begin{array}{c}\text { Number } \\
\text { Tagged }\end{array}$ & Release Date & Release Location & $\begin{array}{c}\text { Number } \\
\text { Released }\end{array}$ & Mortalities \\
\hline \multirow{2}{*}{$4 / 30 / 2007$} & \multirow{2}{*}{ Yearling } & \multirow{2}{*}{252} & \multirow{2}{*}{$5 / 1 / 2007$} & Forebay & 187 & 2 \\
\hline & & & & Tailrace & 65 & 0 \\
\hline \multirow{2}{*}{$5 / 1 / 2007$} & \multirow{2}{*}{ Yearling } & \multirow{2}{*}{252} & \multirow{2}{*}{$5 / 2 / 2007$} & Forebay & 187 & 0 \\
\hline & & & & Tailrace & 65 & 0 \\
\hline \multirow{2}{*}{$5 / 2 / 2007$} & \multirow{2}{*}{ Yearling } & \multirow{2}{*}{252} & \multirow{2}{*}{$5 / 3 / 2007$} & Forebay & 187 & 0 \\
\hline & & & & Tailrace & 65 & 0 \\
\hline \multirow{2}{*}{$5 / 3 / 2007$} & \multirow{2}{*}{ Yearling } & \multirow{2}{*}{252} & \multirow{2}{*}{$5 / 4 / 2007$} & Forebay & 187 & 2 \\
\hline & & & & Tailrace & 65 & 0 \\
\hline \multirow{2}{*}{$5 / 7 / 2007$} & \multirow{2}{*}{ Yearling } & \multirow{2}{*}{252} & \multirow{2}{*}{$5 / 8 / 2007$} & Forebay & 187 & 2 \\
\hline & & & & Tailrace & 65 & 1 \\
\hline \multirow{2}{*}{ 5/8/2007 } & \multirow{2}{*}{ Yearling } & \multirow{2}{*}{252} & \multirow{2}{*}{ 5/9/2007 } & Forebay & 187 & 0 \\
\hline & & & & Tailrace & 65 & 0 \\
\hline \multirow{2}{*}{ 5/9/2007 } & \multirow{2}{*}{ Yearling } & \multirow{2}{*}{252} & \multirow{2}{*}{$5 / 10 / 2007$} & Forebay & 187 & 0 \\
\hline & & & & Tailrace & 65 & 1 \\
\hline $5 / 10 / 2007$ & Yearlino & 252 & $5 / 11 / 2007$ & Forebay & 187 & 0 \\
\hline (3) & Y caining & 202 & / & Tailrace & 65 & 1 \\
\hline $5 / 14 / 2007$ & Yearlino & 254 & $5 / 17 / 2007$ & Forebay & 189 & 0 \\
\hline $5 / 14 / \angle 00 /$ & 1 canimg & 204 & 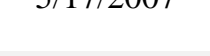 & Tailrace & 65 & 0 \\
\hline 5/15/2007 & Vourling & 252 & 5/16/2007 & Forebay & 187 & 0 \\
\hline $5 / 10 / 200 /$ & redming & 252 & $5 / 10 / 200 /$ & Tailrace & 65 & 0 \\
\hline $5 / 16 / 2007$ & Yearling & 253 & $5 / 17 / 2007$ & Forebay & 188 & 1 \\
\hline J/ $10 / \angle 00 /$ & Teanimg & 205 & J/1// & Tailrace & 65 & 0 \\
\hline 5/17/מم007 & Yearling & 253 & $5 / 18 / 2007$ & Forebay & 188 & 0 \\
\hline J/1//Z00 & Y Tanms & 203 & $3 / 10 / 200 /$ & Tailrace & 65 & 0 \\
\hline $5 / 21 / 2007$ & Yearling & 253 & $5 / 22007$ & Forebay & 188 & 0 \\
\hline$J / \angle 1 / \angle 007$ & Teanimg & 205 & $\mathrm{~J} / 2</ \angle 007$ & Tailrace & 65 & 0 \\
\hline 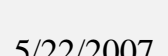 & Yearling & 253 & $5 / 23 / 2007$ & Forebay & 188 & 0 \\
\hline$J / \angle 2 / \angle 00 /$ & redming & 253 & $J / \angle 3 / \angle 00 /$ & Tailrace & 65 & 0 \\
\hline 7 & Yearling & 253 & $5 / 24007$ & Forebay & 188 & 0 \\
\hline 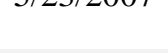 & Y Tanms & 203 & $J / 24 /<00 /$ & Tailrace & 65 & 0 \\
\hline $5 / 24 / 2007$ & Yearlino & 253 & $5 / 25 / 2007$ & Forebay & 188 & $10^{(a)}$ \\
\hline 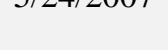 & К caining & 205 & 位 & Tailrace & 65 & 0 \\
\hline Totals & Yearlino & 4040 & Totals & Forebay & 3,000 & $17^{(\mathrm{b})}$ \\
\hline IVtals & I eanming & 4040 & IVtals & Tailrace & 1,040 & 3 \\
\hline
\end{tabular}

(a) These fish were intentionally sacrificed to reach a goal of tagging and releasing 20 dead fish in spring.

(b) Ten of these fish were intentionally sacrificed to reach a goal of tagging and releasing 20 dead fish in spring. 
Table 2.2. Numbers of Tagged and Released Subyearling Chinook Salmon in Summer 2007. The number released included the number listed in the Mortalities column.

\begin{tabular}{|c|c|c|c|c|c|c|}
\hline Date & Age Class & $\begin{array}{l}\text { Number } \\
\text { Tagged }\end{array}$ & Release Date & Release Location & $\begin{array}{l}\text { Number } \\
\text { Released }\end{array}$ & Mortalities \\
\hline \multirow{2}{*}{$6 / 20 / 2007$} & \multirow{2}{*}{$\begin{array}{l}\text { Sub- } \\
\text { Yearling }\end{array}$} & \multirow{2}{*}{289} & \multirow{2}{*}{$6 / 21 / 2007$} & Forebay & 215 & 0 \\
\hline & & & & Tailrace & 74 & 0 \\
\hline \multirow{2}{*}{$6 / 21 / 2007$} & \multirow{2}{*}{$\begin{array}{c}\text { Sub- } \\
\text { Yearling }\end{array}$} & \multirow{2}{*}{289} & \multirow{2}{*}{$6 / 22 / 2007$} & Forebay & 215 & 1 \\
\hline & & & & Tailrace & 74 & 0 \\
\hline \multirow{2}{*}{$6 / 25 / 2007$} & \multirow{2}{*}{$\begin{array}{c}\text { Sub- } \\
\text { Yearling }\end{array}$} & \multirow{2}{*}{289} & \multirow{2}{*}{ 6/26/2007 } & Forebay & 215 & 2 \\
\hline & & & & Tailrace & 74 & 0 \\
\hline \multirow{2}{*}{$6 / 26 / 2007$} & \multirow{2}{*}{$\begin{array}{c}\text { Sub- } \\
\text { Yearling }\end{array}$} & \multirow{2}{*}{288} & \multirow{2}{*}{$6 / 27 / 2007$} & Forebay & 214 & 1 \\
\hline & & & & Tailrace & 74 & 0 \\
\hline \multirow{2}{*}{ 6/27/2007 } & \multirow{2}{*}{$\begin{array}{c}\text { Sub- } \\
\text { Yearling }\end{array}$} & \multirow{2}{*}{288} & \multirow{2}{*}{$6 / 28 / 2007$} & Forebay & 214 & 0 \\
\hline & & & & Tailrace & 74 & 0 \\
\hline \multirow{2}{*}{$6 / 28 / 2007$} & \multirow{2}{*}{$\begin{array}{c}\text { Sub- } \\
\text { Yearling }\end{array}$} & \multirow{2}{*}{289} & \multirow{2}{*}{ 6/29/2007 } & Forebay & 215 & 1 \\
\hline & & & & Tailrace & 74 & 1 \\
\hline \multirow{2}{*}{ 7/2/2007 } & \multirow{2}{*}{$\begin{array}{l}\text { Sub- } \\
\text { Yearling }\end{array}$} & \multirow{2}{*}{288} & \multirow{2}{*}{$7 / 3 / 2007$} & Forebay & 214 & 0 \\
\hline & & & & Tailrace & 74 & 0 \\
\hline \multirow{2}{*}{ 7/3/2007 } & \multirow{2}{*}{$\begin{array}{c}\text { Sub- } \\
\text { Yearling }\end{array}$} & 288 & $7 / 4 / 2007$ & Forebay & 214 & 0 \\
\hline & & 200 & $/ / 4 / 200 /$ & Tailrace & 74 & 0 \\
\hline $7 / 4 / 2007$ & Sub- & 288 & $7 / 5 / 2007$ & Forebay & 214 & 0 \\
\hline $1 / 4 / \angle 00 /$ & Yearling & 200 & (1/ & Tailrace & 74 & 0 \\
\hline $7 / 5 / 2007$ & Sub- & 288 & $7 / 6 / 2007$ & Forebay & 214 & 0 \\
\hline //J/ $\angle 007$ & Yearling & 200 & $/ / 6 / 200 /$ & Tailrace & 74 & 0 \\
\hline $7 / 0 / 007$ & Sub- & 200 & 7000/10 & Forebay & 214 & 1 \\
\hline$/ / 9 / \angle 00 /$ & Yearling & 289 & $/ / 10 / \angle 00 /$ & Tailrace & 75 & 0 \\
\hline $7 / 10 / 2007$ & Sub- & 284 & $7 / 11 / 2007$ & Forebay & 214 & 2 \\
\hline 110 & Yearling & 207 & 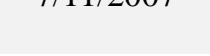 & Tailrace & 70 & 1 \\
\hline $7 / 11 / 2007$ & Sub- & 293 & 7000/1/7 & Forebay & 213 & 2 \\
\hline$/ 111 / \angle 007$ & Yearling & 250 & /1 $12<\angle 00$ & Tailrace & 80 & 0 \\
\hline $7 / 12 / 2007$ & Sub- & 289 & $7 / 13 / 2007$ & Forebay & 214 & $8^{(a)}$ \\
\hline & Yearling & & & Tailrace & 75 & 0 \\
\hline Total & Sub- & 4039 & Total & Forebay & 2,999 & $18^{(a)}$ \\
\hline 10tal & Yearling & 4005 & 10lal & Tailrace & 1,040 & 2 \\
\hline
\end{tabular}

(a) Six of these fish were intentionally sacrificed to reach a goal of tagging and releasing 20 dead fish in summer. 
Tagged treatment fish were transported from the JMF to the spillway forebay three times each afternoon. Each time, from 12 to 14 buckets of water and fish were removed from the transport totes in a pickup truck and loaded into the stern of a boat. Buckets were opened to check for dead fish. We scanned all dead fish with a BioMark portable transceiver PIT-tag scanner so that identities could be established and recorded. According to protocol, biologists pithed dead fish or cut through their gill arches. Fish in each transport group were distributed evenly among five locations from the Washington to Oregon shore (Figure 2.5). The first release location was $30.5 \mathrm{~m}$ upstream of pier 1, which by study naming convention was located just south of bay 1 . The second, third, and fourth locations were $45.7 \mathrm{~m}$ upstream of piers 7, 9, and 11, respectively. The fifth release location was $30.5 \mathrm{~m}$ upstream of pier 17. Boat operators used an onboard global positioning system (GPS) to move the boat to a specific latitude and longitude and put the motor in neutral while the crew gently poured fish into the river and recorded the location, bucket number, and time of release. Acoustic tags and PIT tags in each bucket were part of the tagging database, so records clearly indicate the exact release time of each fish.

Fisheries researchers with NOAA delivered three successive releases of fish into the tailrace of the Bonneville Dam spillway each afternoon, and those releases were coordinated to begin 1 hour after forebay releases. The goal was to have adequate temporal mixing of treatment- and reference-release groups in the tailwater so both groups would experience similar conditions related to flow, water quality, and predation. The three afternoon releases of tailrace fish were distributed among three locations along a line transect across the river $2 \mathrm{~km}$ downstream of the spillway.

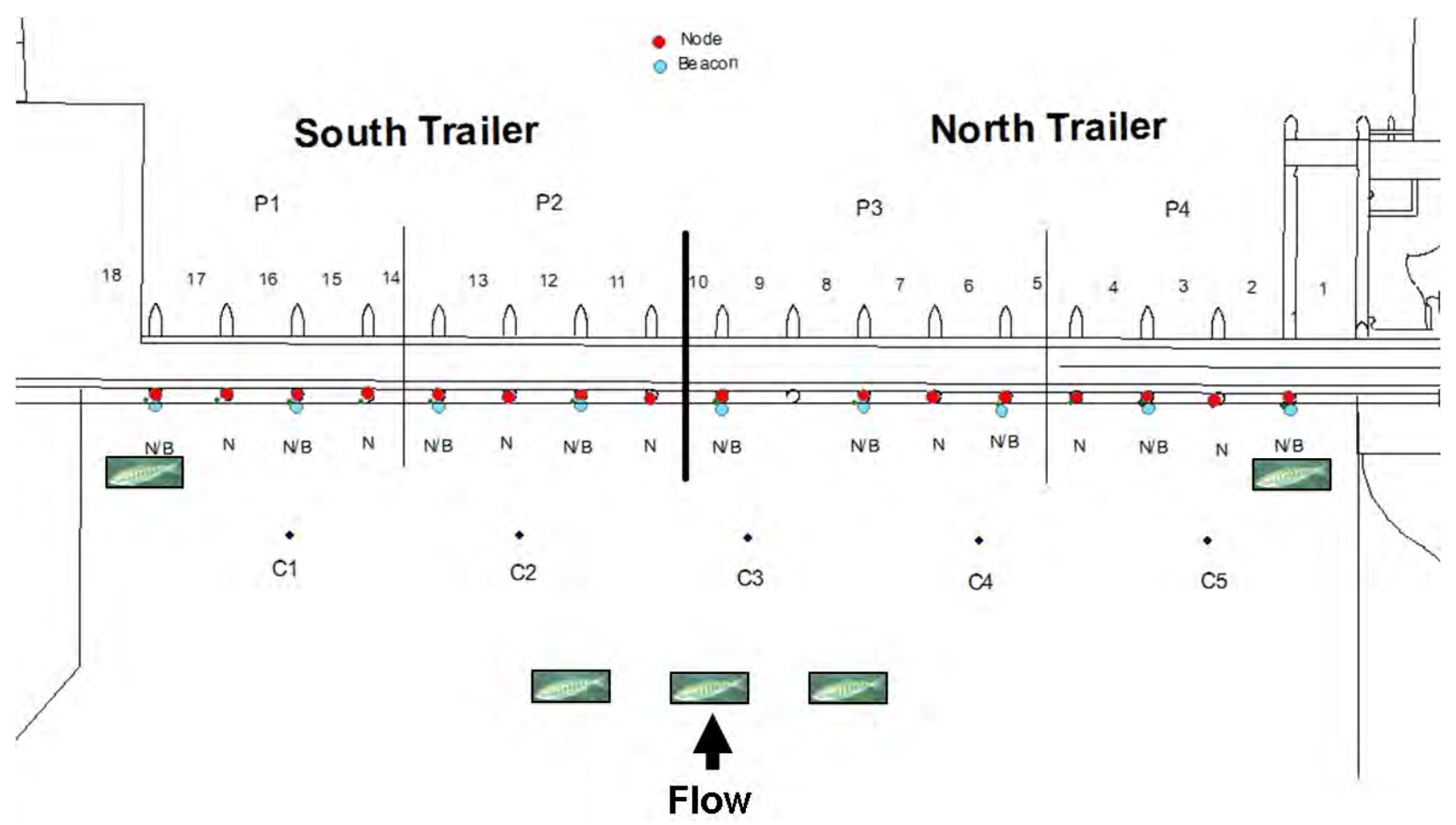

Figure 2.5. Plan View of the Bonneville Dam Spillway Showing Fish Release Sites (fish pictures) and Locations of 16 Cabled Hydrophones (red circles) and Beacons (blue circles) on Piers. The black spades labeled C1 through C5 indicate locations of star clusters. 


\subsection{Steps Taken to Minimize Handling Impacts}

Numerous steps were taken to minimize the handling impacts of collection and surgical procedures. Fish were collected in conjunction with routine JMF collections. The use of these already-collected fish allowed us to minimize the impact of having to collect more fish to meet our quota for the day.

The number of personnel on hand was the biggest contributor to ensuring that all tagged fish were handled in a manner that was least intrusive to their survivability. Overall handling time was a consideration that was met with enough personnel to tag the fish within a 4- or 5-hour period. On most days, 11 people participated. One individual collected fish and two were responsible for anesthetizing fish and delivering them to be weighed and measured. Two people weighed, measured, and recorded data; one delivered fish to surgeons; three surgically implanted fish with tags; and two continuously moved buckets containing water and fish from the post-surgery recovery location to the insulated holding tanks outside.

Several steps were used in the tagging process to minimize handling impacts. Sterilization of all surgical instruments was a continuous and emphasized protocol. Each surgeon used three to four complete sets of instruments. Once used, the instruments were placed in a $70 \%$ ethanol solution for approximately 10 minutes. All instruments were rotated into distilled water for 10 minutes to "wash" the residual ethanol off prior to their use during the next surgery. This procedure reduced the introduction of bacteria and other harmful particulates into the incision and suture site. A synthetic fish slime (Poly-Aqua) was liberally used on the surgical pad to counteract the disruption to mucus membranes during surgical procedures (Table 2.3). Local anesthetic was not used on the incision site because of its characteristic of further disrupting the mucus membrane.

Table 2.3. Dilution of Poly-Aqua Used in Surgical Procedures

\begin{tabular}{cc}
\hline Volume (l) & Poly-Aqua \\
\hline 1 & 0.15 \\
2 & 0.30 \\
3 & 0.45 \\
4 & 0.60 \\
5 & 0.75 \\
6 & 0.90 \\
10 & 1.50 \\
2 & 3.00 \\
5 & 7.50 \\
\hline
\end{tabular}

The surgical procedure was designed to minimize complications. The proximity of the incision to the midline was closely monitored to ensure that neither the incision nor the suture went through the midline.

Closely monitoring fish condition during anesthesia was a vital part of minimizing handling effects. Anesthesia buckets were refreshed regularly to maintain $\pm 2{ }^{\circ} \mathrm{C}$ of current river temperatures. Anesthesia solutions were either replaced or cooled with ice when temperatures exceeded protocols. Recovery buckets were monitored in the same manner. 
Handling impacts during transportation and release were minimized in several ways. Buckets were dark in color to reduce the stress induced by bright light and sudden movements. During load up from post-surgical holding to transport vehicles, each Bonar tote was flushed with river water before filling it to reduce heat transfer during transport. Shading was provided on the boat to reduce the heating effects from sunlight on dark surfaces.

\subsection{Detection of Tagged Fish}

The nodes and arrays, array locations, node deployment, retrieval, servicing, and redeployment practices are described in the following sections.

\subsubsection{Nodes and Arrays}

The SC autonomous acoustic telemetry receiver (node) used in this study consisted of two coupled parts. The top was made from Schedule 40 10.16-cm-diameter PVC pipe that was capped at the top and had a fitting with male threading at the bottom (Figure 2.6). The cap was modified for water-tight seating of a hydrophone, and the body below the cap housed the analog and digital boards for processing detected tag signals. A lubricated 10.16-cm-diameter rubber O-ring was fitted over the lower threaded end so that it would form a water-tight seal when the node top was screwed together with the bottom. The node bottom was made from approximately $1 \mathrm{~m}$ of 10.16-cm-diameter PVC pipe and the upper end had a fitting with female threads for coupling it to the node top. The lower end of the node bottom was capped and a stainless-steel harness was located just below the upper fitting so the node could be attached to an anchor system, which is described later. An acoustic beacon that transmitted a signal four times louder that acoustic tags once every 15 seconds was attached to the outside of the battery housing just below the threaded end of the housing. This beacon was used to determine the location of a node if it didn't surface after it was acoustically released from an anchor. Beacons also could be used to determine when an adjacent node disappeared. All autonomous nodes were received from SC with version 2006 software and were thoroughly tested by Precision Acoustic Systems (PAS) to ensure that nodes met acceptancetesting criteria. Functionality also was verified just before each deployment in the river.

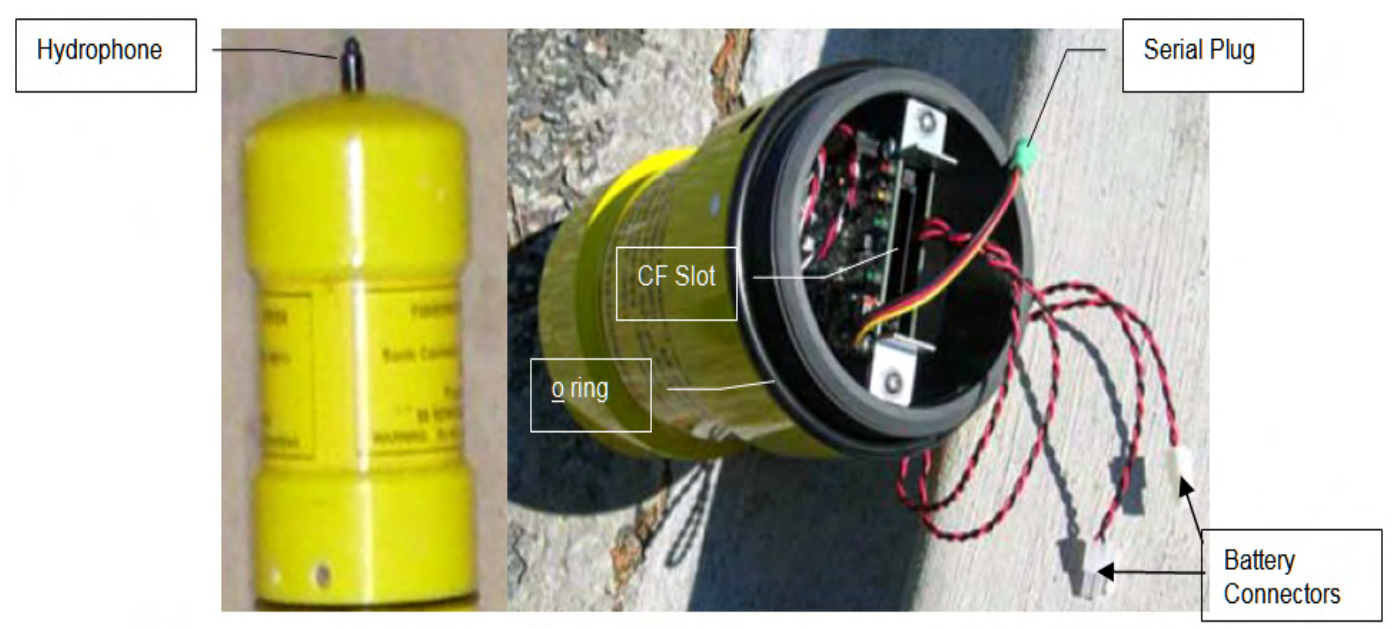

Figure 2.6. Side (left) and Bottom (right) View of a Node Top 
Before deployment, two 30-day lithium-ion batteries were gently lowered into the node bottom and secured in place with a battery-retention device. Wires from the batteries were attached to connectors from the analog board in the node top. One end of a serial cable was connected to a plug from the board set in the node top and the other end was plugged into a laptop computer so that staff could communicate with the node, set its date and time, and verify detection of a beacon tag. Next, a 1-GB SanDisk Extreme III CompactFlash (CF) card was mounted in a slot on the board set, and the node top and bottom were screwed together until beveled edges of each piece compressed the O-ring to form a watertight seal. Just before putting the node into the water, we verified that a light-emitting diode (LED) on the node top housing was flashing, which indicated that the node was functioning properly and data would be written to the CF card. In the water, air space within the sealed node provided positive buoyancy, while the batteries in the node bottom provided ballast to help keep the node upright.

An array is defined as a group of nodes deployed within $1 \mathrm{~km}$ of a specific river cross section to detect passing acoustically tagged fish. Nodes in line transects were deployed at distances $\leq 150 \mathrm{~m}$ from each other and $\leq 90 \mathrm{~m}$ from the shore. However, additional nodes sometimes had to be deployed in entrances to or exits from side channels formed by islands downstream of Bonneville Dam.

\subsubsection{Array Locations}

Figure 2.7 shows all autonomous node arrays deployed below Bonneville Dam in 2007. The Bonneville spillway study was one of several that deployed autonomous nodes in arrays. The Estuary Survival Study conducted in 2007 deployed two survival arrays at each of three locations along the lower Columbia River downstream of the Bonneville spillway study area (two arrays at Kalama, Washington, two at Oak Point, Oregon; one near Cathlamet, Washington; and two near the mouth of the Columbia River). Another study deployed 13 autonomous nodes to study the migration pathways of juvenile Chinook salmon through estuary islands downstream of Cathlamet, Washington.

Table 2.4 provides GPS coordinates of the locations of the cabled hydrophones deployed in the spillway forebay. These hydrophones were used to determine the bay of passage of juvenile Chinook salmon through the spillway. Coordinates for all of our deployments of autonomous nodes in the egress array and three survival arrays are presented in Table 2.5. 


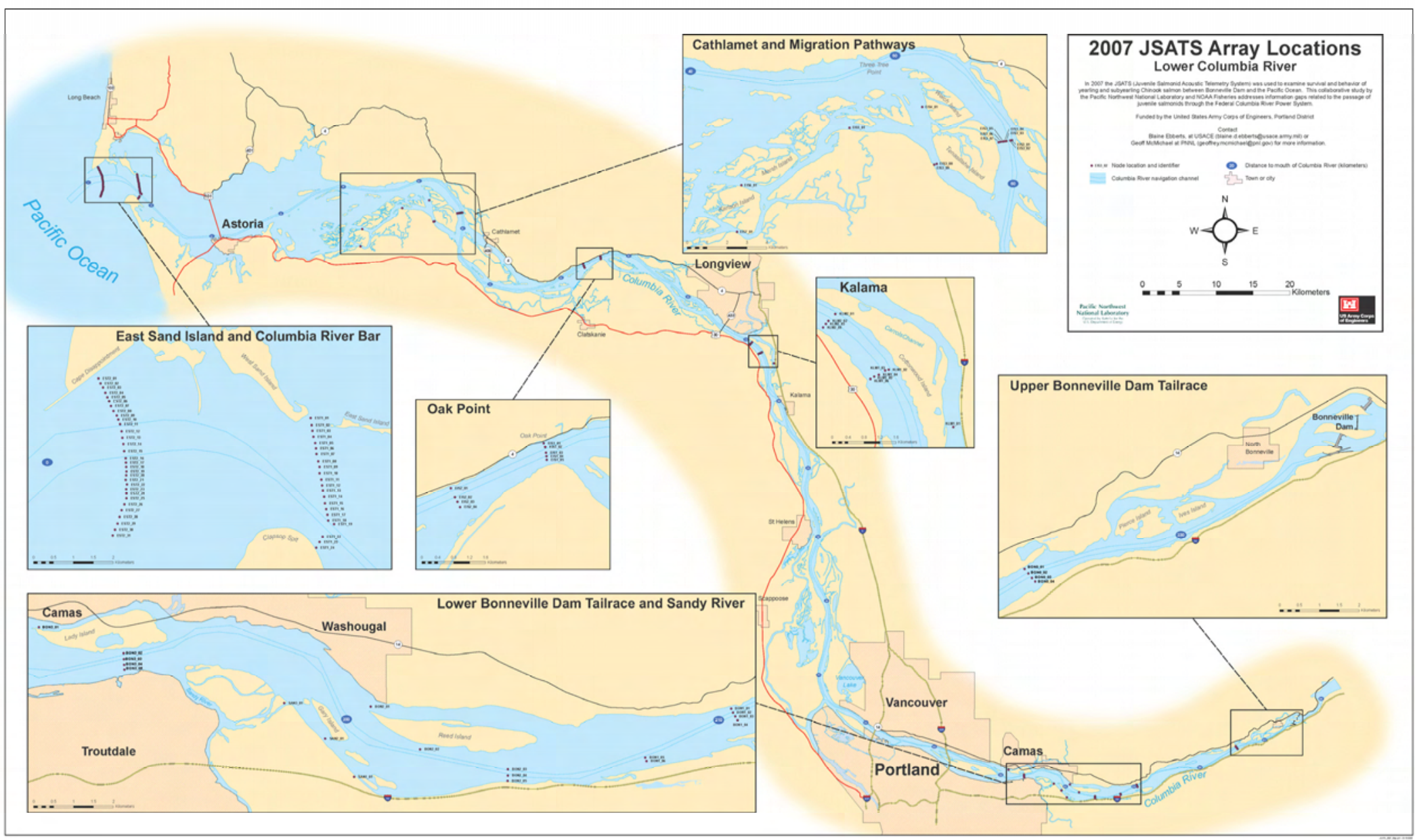

Figure 2.7. Array Locations in the Lower Columbia River in 2007. The upper Bonneville Dam tailrace panel shows the egress array and the lower Bonneville Dam tailrace and the Sandy River panel shows the primary, secondary, and tertiary survival arrays used in this study. 
Table 2.4. Global Positioning System Coordinates of Autonomous Nodes Deployed in 2007. The Universal Transverse Mercator (UTM) zone was 10T.

\begin{tabular}{lcrrrr}
\hline & Array & & & & \\
Array Name & Function & Latitude (Deg) & Longitude (Deg) & UTM Easting & UTM Northing \\
\hline BON01 & Egress & 45.6071079 & -122.0419787 & 574705.03 & 5050842.29 \\
BON02 & Egress & 45.6081507 & -122.0426989 & 574647.49 & 5050957.48 \\
BON03 & Egress & 45.6091935 & -122.0434706 & 574585.93 & 5051072.62 \\
BON04 & Egress & 45.6103443 & -122.0442422 & 574524.24 & 5051199.75 \\
BON11 & Primary & 45.5480142 & -122.2438989 & 559021.5 & 5044108.77 \\
BON12 & Primary & 45.5493797 & -122.2446189 & 558963.87 & 5044259.95 \\
BON13 & Primary & 45.5577501 & -122.2147775 & 561284.14 & 5045212.23 \\
BON14 & Primary & 45.5585767 & -122.2155491 & 561223.02 & 5045303.48 \\
BON15 & Primary & 45.5594393 & -122.2162693 & 561165.88 & 5045398.76 \\
BON16 & Primary & 45.5603737 & -122.2168866 & 561116.69 & 5045502.11 \\
BON21 & Secondary & 45.5428988 & -122.2884613 & 555547.99 & 5043508.65 \\
BON22 & Secondary & 45.5441311 & -122.2884581 & 555547.03 & 5043645.56 \\
BON23 & Secondary & 45.5455446 & -122.2885060 & 555541.89 & 5043802.57 \\
BON24 & Secondary & 45.5496636 & -122.3168160 & 553328.01 & 5044240.97 \\
BON25 & Secondary & 45.560055 & -122.3365157 & 551780.75 & 5045382.54 \\
SAN1 & Secondary & 45.5517531 & -122.3478056 & 550907.14 & 5044453 \\
SAN2 & Secondary & 45.5617378 & -122.3933985 & 547339.99 & 5045534.36 \\
SAN3 & Secondary & 45.5564201 & -122.3681832 & 549312.49 & 5044958.76 \\
BON31 & Tertiary & 45.566878 & -122.4057460 & 546372.16 & 5046098.22 \\
BON32 & Tertiary & 45.5681095 & -122.4058476 & 546363.21 & 5046234.98 \\
BON33 & Tertiary & 45.5693773 & -122.4057950 & 546366.28 & 5046375.86 \\
BON34 & Tertiary & 45.5706451 & -122.4057424 & 546369.34 & 5046516.74 \\
BON35 & Tertiary & 45.5752008 & -122.4340996 & 544153.08 & 5047006.88 \\
\hline & & & & & \\
\hline
\end{tabular}


Table 2.5. Global Positioning System Coordinates of Cabled Hydrophones Deployed in the Forebay of the Bonneville Dam Spillway in 2007. In location name, C stands for cluster, P stands for pier, and pier numbers indicate the spill bay north of the pier. The UTM zone was 10T.

\begin{tabular}{cccccc}
\hline Location Name & $\begin{array}{c}\text { Number of } \\
\text { Hydrophones }\end{array}$ & Latitude (Deg) & Longitude (Deg) & UTM Easting & $\begin{array}{c}\text { NTM } \\
\text { Northing }\end{array}$ \\
\hline C1 & 4 & 45.6433451 & -121.9401871 & 582589.33 & 5054968 \\
C3 & 4 & 45.6438712 & -121.9401874 & 582588.53 & 5055027 \\
C4 & 4 & 45.6443937 & -121.9401750 & 582588.73 & 5055085 \\
C5 & 4 & 45.6449225 & -121.9401658 & 582588.67 & 5055143 \\
P1 & 4 & 45.6454150 & -121.9401630 & 582588.16 & 5055198 \\
P3 & 1 & 45.6456004 & -121.9406103 & 582553.04 & 5055218 \\
P4 & 1 & 45.6452721 & -121.9406200 & 582552.76 & 5055182 \\
P5 & 1 & 45.6451067 & -121.9406252 & 582552.6 & 5055163 \\
P7 & 1 & 45.6449403 & -121.9406318 & 582552.33 & 5055145 \\
P9 & 1 & 45.6446120 & -121.9406405 & 582552.13 & 5055108 \\
P11 & 1 & 45.6442835 & -121.9406513 & 582551.78 & 5055072 \\
P13 & 1 & 45.6439544 & -121.9406602 & 582551.57 & 5055035 \\
P14 & 1 & 45.6436280 & -121.9406695 & 582551.32 & 5054999 \\
P15 & 1 & 45.6434621 & -121.9406756 & 582551.09 & 5054981 \\
P16 & 1 & 45.6432982 & -121.9406792 & 582551.05 & 5054962 \\
P17 & 1 & 45.6431337 & -121.9406846 & 582550.87 & 5054944 \\
\hline
\end{tabular}

\subsubsection{Bonneville Spillway Forebay and the Egress Array}

We installed five star clusters like the one shown in Figure 2.8 approximately $125 \mathrm{ft}$ upstream from the spillway and single hydrophones on 16 of 19 spillway piers, each at a depth of about $3.1 \mathrm{~m}$ or elevation $19.5 \mathrm{~m}$ above MSL (Figure 2.5). Individual hydrophones on piers were not baffled during the first 2 weeks of the spring season, but baffles (Figure 2.9) were added during the third week, and all pier hydrophones were baffled for the last 4 days of spring and all of summer. Baffles were lined with a sound-absorbing material to exclude loud noises emanating from spill gates downstream of hydrophones. Baffling greatly increased the ratio of approaching tag signals relative to background noise levels, and significantly increased the percentage of successful tag decodes. The forebay array was used to determine where treatment fish passed the spillway (i.e., via bays with deep or shallow spill deflectors).

We installed four autonomous nodes in an egress array about $9 \mathrm{~km}$ downstream of Bonneville Dam to assess egress rates during each season studied (Figure 2.10). It would have been desirable to have located the egress array closer to the dam, but entrained air from the spillway discharge reduces the detectability of acoustic tags. 


\subsubsection{Survival Arrays}

The primary survival array with six autonomous nodes was centered on rkm 209.2 near Rooster Rock State Park, Oregon, and the secondary array with nine nodes was centered on rkm 202.7 near the center of Reed Island (Figure 2.11). The tertiary array with five autonomous nodes was centered on rkm 192 near Lady Island and Camas, Washington (Figure 2.12).

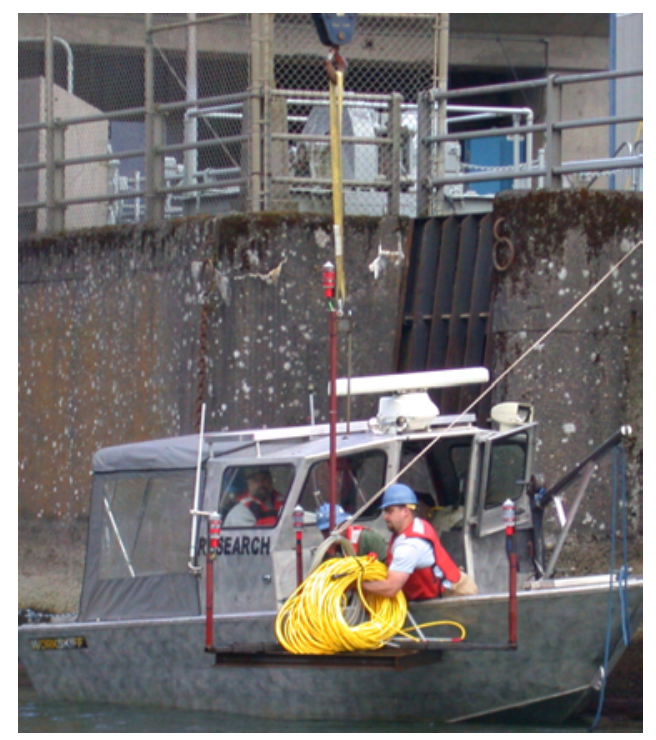

Figure 2.8. Photograph of a Star Cluster of Four Hydrophones Being Lowered from the Roadway on the North Side of the Spillway Forebay to a Boat with a Crane. The separation distance between each of the four hydrophones was $2 \mathrm{~m}$, and the design was intended to allow for out-of-baseline tracking of fish passing over the cluster.

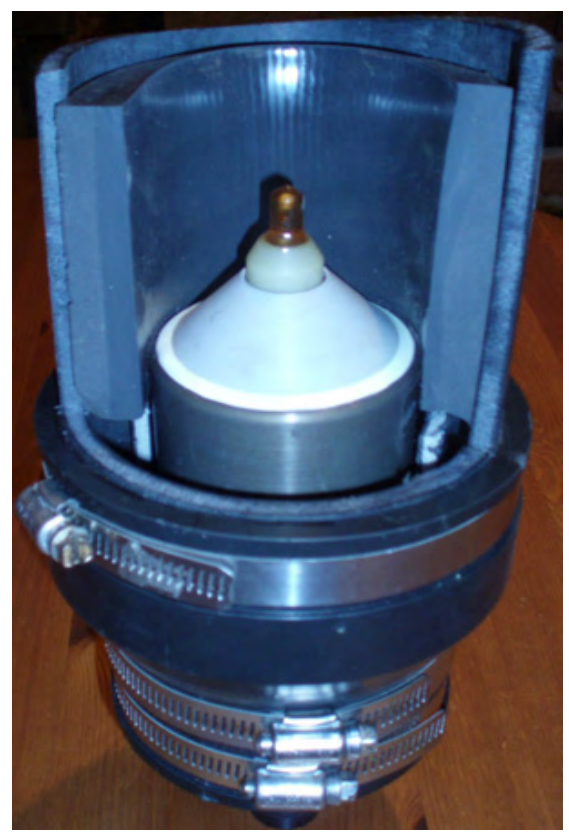

Figure 2.9. Photograph of a Hydrophone Baffled from the Direction of a Spill Gate 


\section{Upper Bonneville Dam Tailrace}

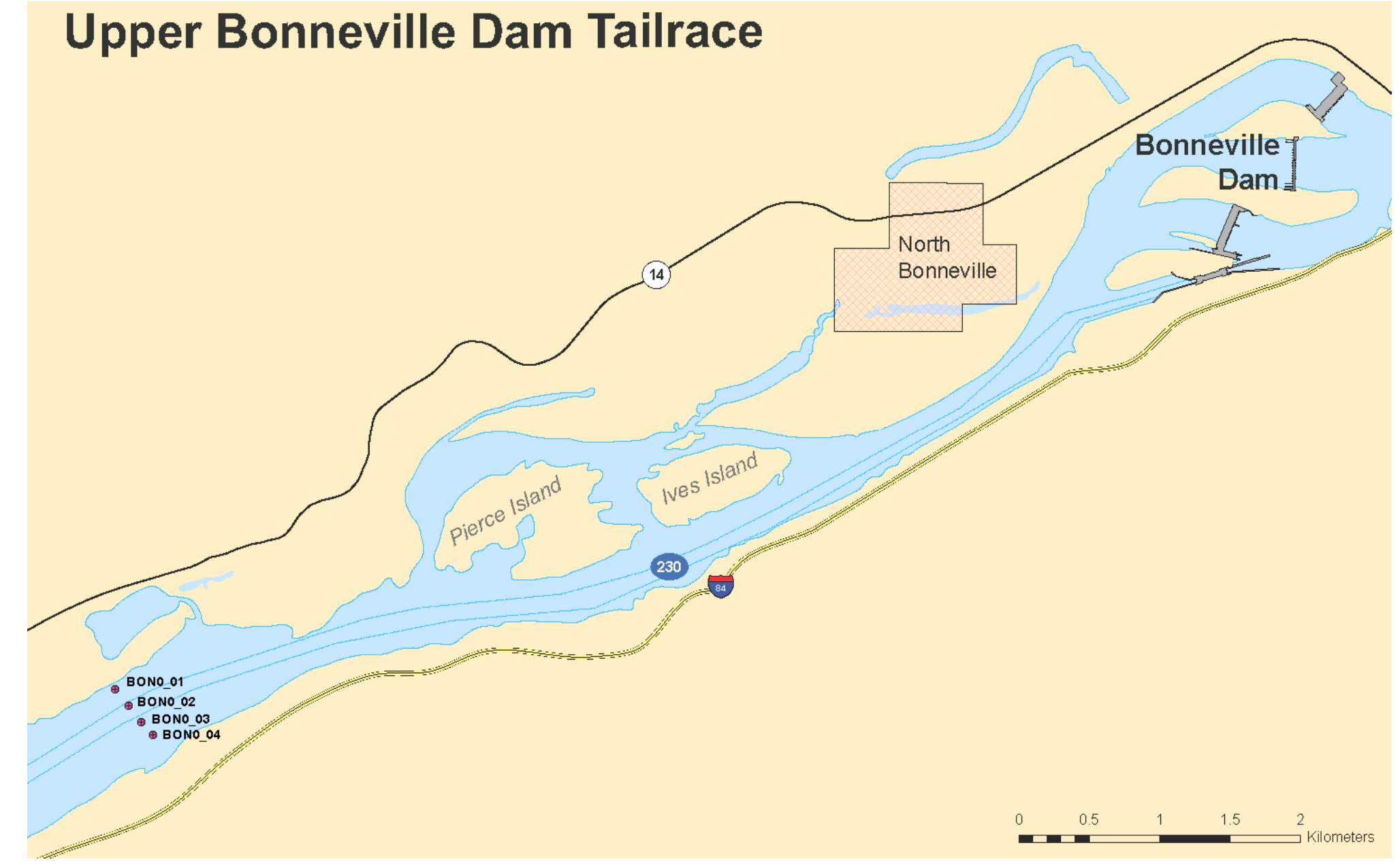

Figure 2.10. The Location of Autonomous Nodes in the Bonneville Dam Egress Array 9 km Downstream of the Dam 


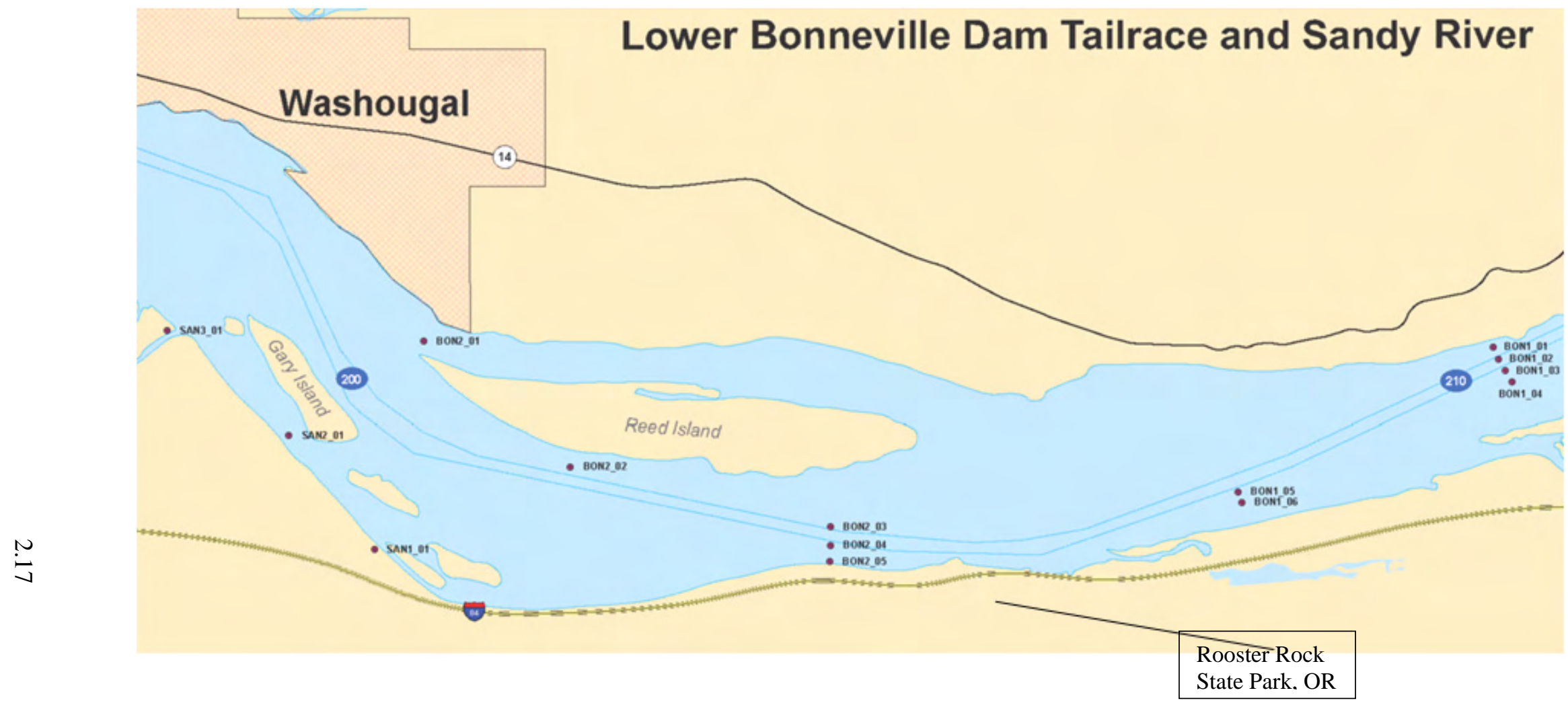

Figure 2.11. Locations of Autonomous Nodes in the Primary Array (BON1_01 through BON1_06) Near Rooster Rock State Park, and in the Secondary Array Near Reed Island (BON2_01 through BON2_05 and SAN1 through SAN3). The primary and secondary arrays were centered around locations that were 25 and $34.4 \mathrm{~km}$ downstream of Bonneville Dam, respectively. 


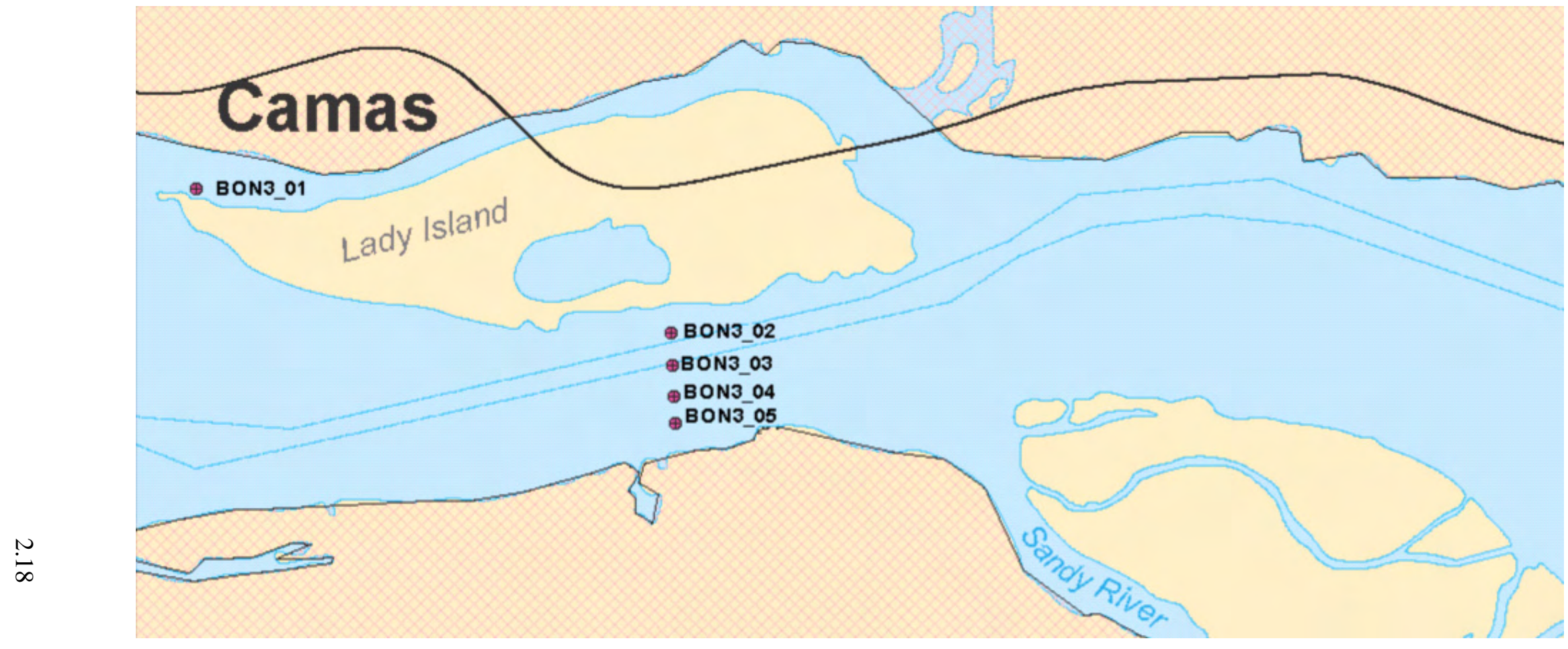

Figure 2.12. Autonomous Node Locations in the Tertiary Array Near Lady Island and Camas, Washington (Bon3_01 through BON 3_05) approximately $42.4 \mathrm{~km}$ Downstream of Bonneville Dam 


\subsubsection{Node Deployment}

All autonomous nodes were rigged similarly to the configuration shown in Figure 2.13. A 1.5-m section of line with three 2.72-kg buoyancy floats was attached to a strap half way between the node tip and the battery housing bottom. An InterOcean Systems Model 11 acoustic release was attached to the other end of the 1.5-m line. Depending on water depth, 0.48-cm-diameter wire rope from 0.3- to 2-m long and was attached to the bottom of the acoustic release device, and the other end of the wire rope was shackled to a 34-kg anchor. In water $<5.5 \mathrm{~m}$ deep, we bound the node, float line, and acoustic release together with zip-ties and used a 0.3-m wire-rope lead to keep the entire package $<1.5 \mathrm{~m}$ long.

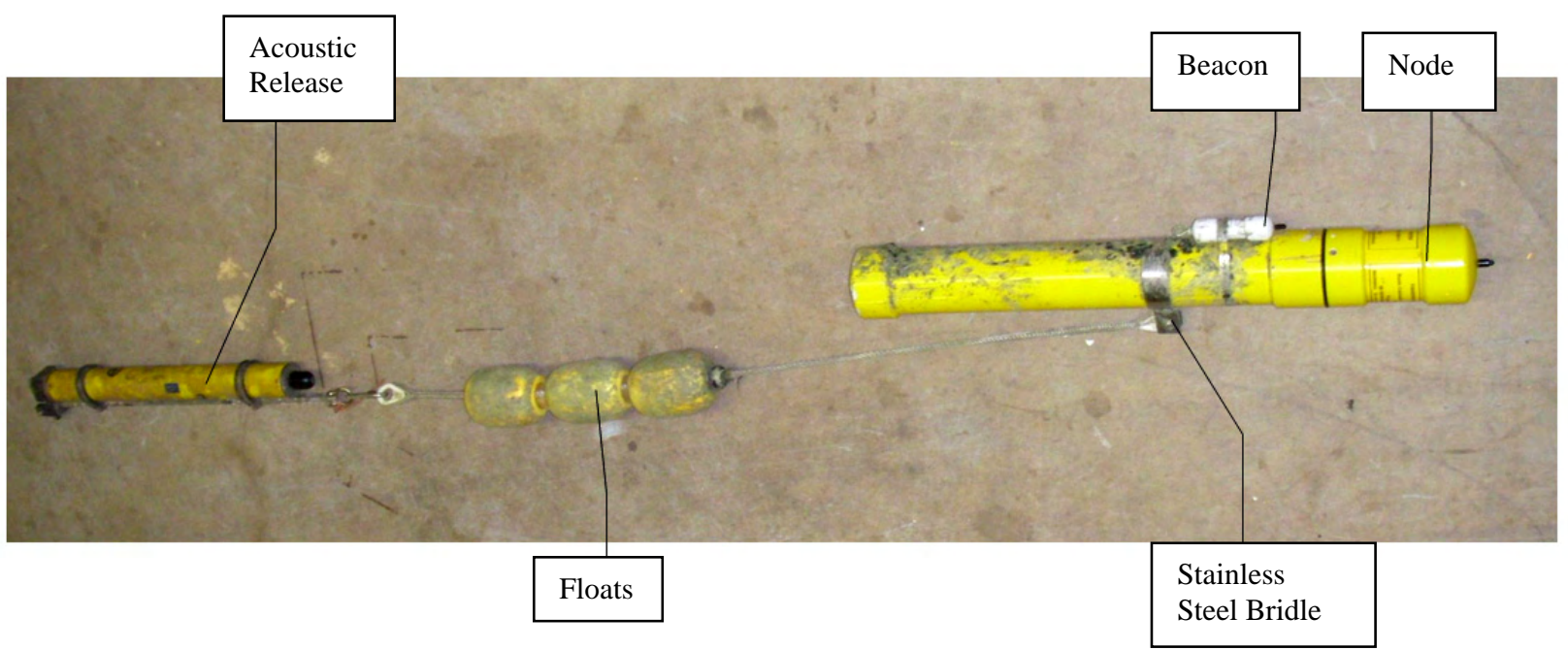

Figure 2.13. Node Rigging Without a 34-kg Anchor Shown from 0.3 to $1.8 \mathrm{~m}$ Below the Acoustic Release

\subsubsection{Node Retrieval, Servicing, and Redeployment}

We retrieved most nodes and downloaded data every week. The first step in servicing a node was to trigger its acoustic release by entering a release-specific code into a transceiver that transmitted an electrical signal to an underwater transducer, which in turn converted the electrical signal into codespecific acoustic transmissions to activate the release mechanism. Once the node, floats, and acoustic release surfaced, they were retrieved by boat (Figure 2.14). The next step was to dry the node with a towel, open it, eject the CF card, and download data from the card to a laptop computer. We checked the data file to verify that the node collected data throughout its last deployment, records were continuous, and records included time stamps and tag detections. We replaced the CF card every time nodes were retrieved and batteries at about 28-day intervals. When the data were corrupt, the node top was replaced with a new one and the faulty top was sent to SC for repair. The most common problem was damage to the hydrophone tip. Nodes were serviced and redeployed until August 30, 2007. 


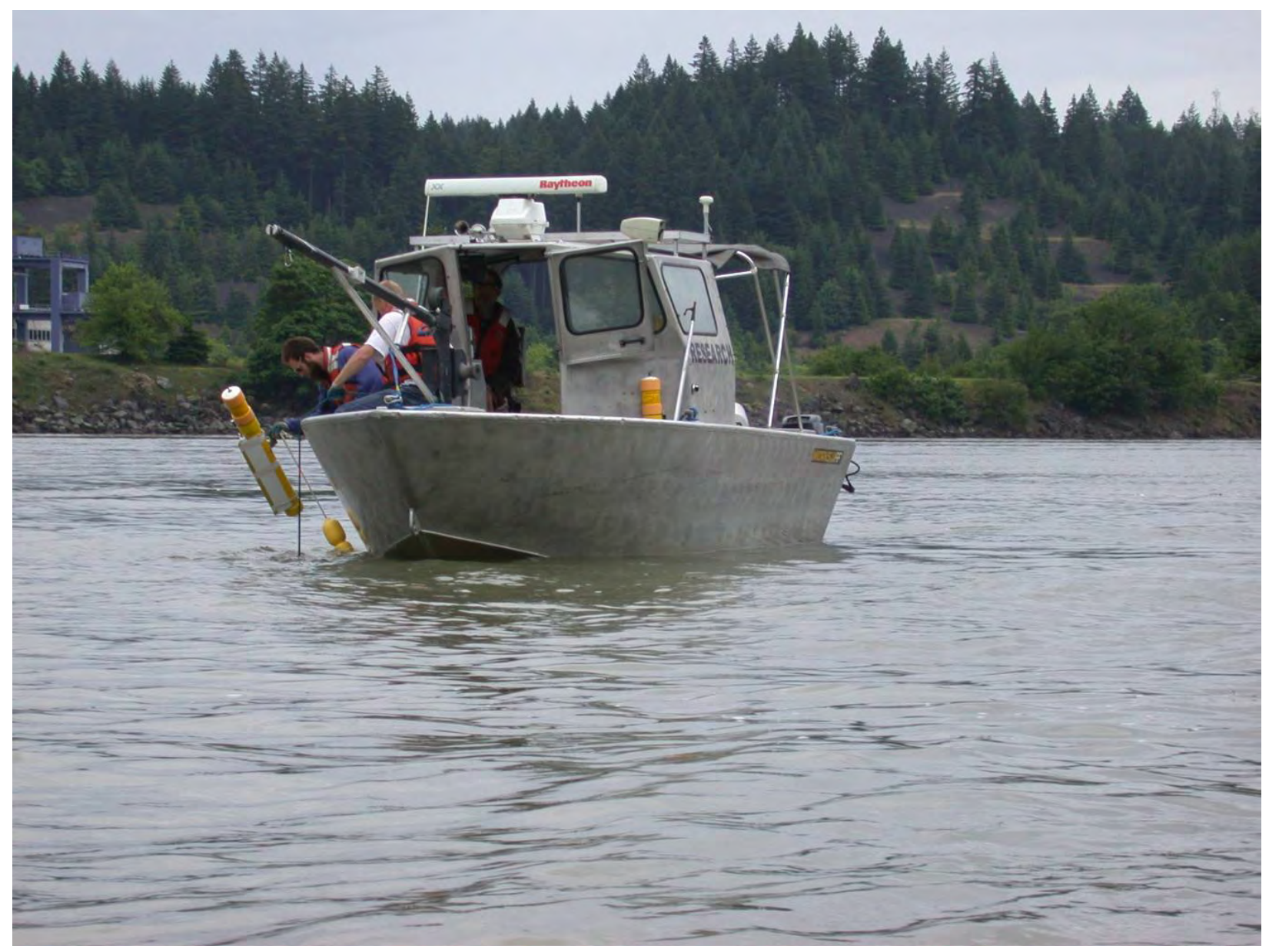

Figure 2.14. Autonomous Node Retrieval

\subsection{Project Discharge and Water Temperature}

Project discharge data by spill bay and turbine unit and forebay and tailwater elevations were acquired in 5-minute increments by the automated data-acquisition systems at Bonneville Dam and provided to us by the CENWD. Average discharge and forebay water temperature data from 1997 through 2007 were downloaded from the DART (Data Access in Real Time) website (http://www.cbr.washington.edu/dart). Five-minute discharges for the entire project and spillway were averaged by day and plotted along with 10 -year averages. Tailrace elevation data acquired between 1400 and 1900 hours were plotted by date so that seasonal trends would be visible.

\subsection{Data Processing and Validation}

As in 2006 (Ploskey et al. 2007b), tag-detection data from JSATS autonomous nodes were processed in two ways as a quality-control measure, and we found no significant difference in detection and survival estimates based upon detection histories. One method involved using TagViz software, and the other involved processing data with programs written in the Statistical Analysis System (SAS) code. 
Regardless of the method, tag, release, and detection data were merged into a single dataset, and the same rules were applied to detection data to identify array detection and generate detection histories for every tag. The rules included the following:

1. Tag codes detected were downstream of the release site.

2. Tag codes were detected after the release date and time.

3. Decode intervals were from 3 to 22 seconds for tags transmitting once every 5 seconds. Tags transmitting once every 10 seconds (Snake River tags) were ignored.

4. For 5-second tags, we required at least four identical decodes in 60 seconds from any node in an array before we counted an acoustically tagged fish as detected by an array.

For identifying a series of unique tag detections by cabled hydrophones deployed in the spillway forebay, a signal-to-noise ratio of 3:1 also was required, and the detection rate was reduced from 4 in 60 seconds to 4 in 120 seconds. Rules for cabled nodes were as follows:

1. Tag codes detected were downstream of the release site.

2. Tag codes were detected after the release date and time.

3. Decode intervals were from 3 to 22 seconds for tags transmitting once every 5 seconds. Tags transmitting once every 10 seconds (Snake River tags) were ignored.

4. The signal-to-noise ratio of decoded signals was at least 3:1.

5. We required at least four identical decoded signals in 120 seconds from a 5 -second tag to identify a detection series in the spillway forebay.

\subsection{Study of Tag Life}

As part of the 2007 Tag Effects Study, Dr. Richard Brown and colleagues implanted tags subsampled from all tags used in this study into juvenile Chinook salmon from Priest Rapids Hatchery and monitored transmissions from those tags until every tag quit transmitting. When a tagged fish died, the tag was re-implanted in another fish until the tag died. A JSATS mobile node was used to listen for tags daily and tag-life history data were compiled to produce tag-life curves, which indicate the percent of each tag type transmitting as a function of days since activation. There were 29 SC 2006 tags, 66 SC 2007 tags, and 52 ATS 2007 tags. The SC tags were released in spring, and ATS tags were released in summer. We describe the use of tag-life study results in Section 2.9.5 below.

\subsection{Statistical Methods}

In this report, we define estimates of single-release reach survival by the upstream and downstream boundaries of the reach of interest. Some additional definitions are needed to clarify paired-release survival metrics discussed in the following sections: 
Forebay is the reach of river immediately upstream of the dam where operations at the dam are the primary contributing factor to the velocity and direction of water flow. The upstream boundary of a forebay is where a significant alteration in water-flow allocation through dam operational changes affects water velocity or direction. The downstream boundary is the upstream face of the dam. The location of the spillway forebay array was on or within about $45 \mathrm{~m}$ of the concrete and there was no upstream forebay entrance array in this study.

Tailrace is the reach of river immediately downstream of the dam where dam operations are the primary factor affecting the velocity and direction of water flow. The upstream boundary of the tailrace is the downstream face of the dam and the downstream boundary is where operational changes at the dam no longer affect the direction of water flow, and mixing from the spillway and powerhouse is complete. The NOAA Fisheries release site was about $2 \mathrm{~km}$ downstream of the spillway adjacent to the USACE boat launch and near the downstream boundary of the tailrace.

Tailwater in this study is the reach of river downstream of the tailrace to the point where salt-water mixing occurs. Tailwater is synonymous with reservoir or pool when it lies between two dams, but Bonneville Dam is the last dam on the lower Columbia River.

Passage-route survival is the probability of survival for fish passing through any individual route (e.g., spillway, turbine, bypass) to the downstream boundary of the tailrace (release location of a tailrace reference group). In this study, passage route survival was estimated for fish passing through spill bays with deep flow deflectors (end bays 1 through 3 and 16 through 18) and bays with shallow flow deflectors (bays 4 through 15). Numbers of fish tracked to individual bays were too low to warrant calculation of survival by individual spill bay. Estimates of bay-specific survival lacked the precision required to detect significant differences in survival among individual spill bays.

\subsubsection{Defining Virtual Releases}

For both the spring and summer Chinook salmon studies, intentional forebay releases of acoustictagged fish were used to construct treatment groups of fish known to have passed through spill bays containing either shallow or deep flow deflectors. The bay of passage was assigned by the location of the last four detections in the last series of detections.

During spring, 16 replicate trials were formed from these virtual releases through the spill bays, while in summer, 14 replicate groups were formed for the comparison of spill bay treatments. Paired tailrace releases of about 65 fish over a 4-hour period began about 1 hour after treatment releases began. In the forebay of Bonneville Dam, a cabled array of hydrophones was used to detect, track, and assign a bay of passage for as many tagged smolts as possible. These fish with known passage history through either deep flow deflector (i.e., bays 1 through 3 or 16 through 18) or shallow flow deflector spill bays (i.e., bays 4 through 15) were the treatment-release groups (Figure 2.15). 


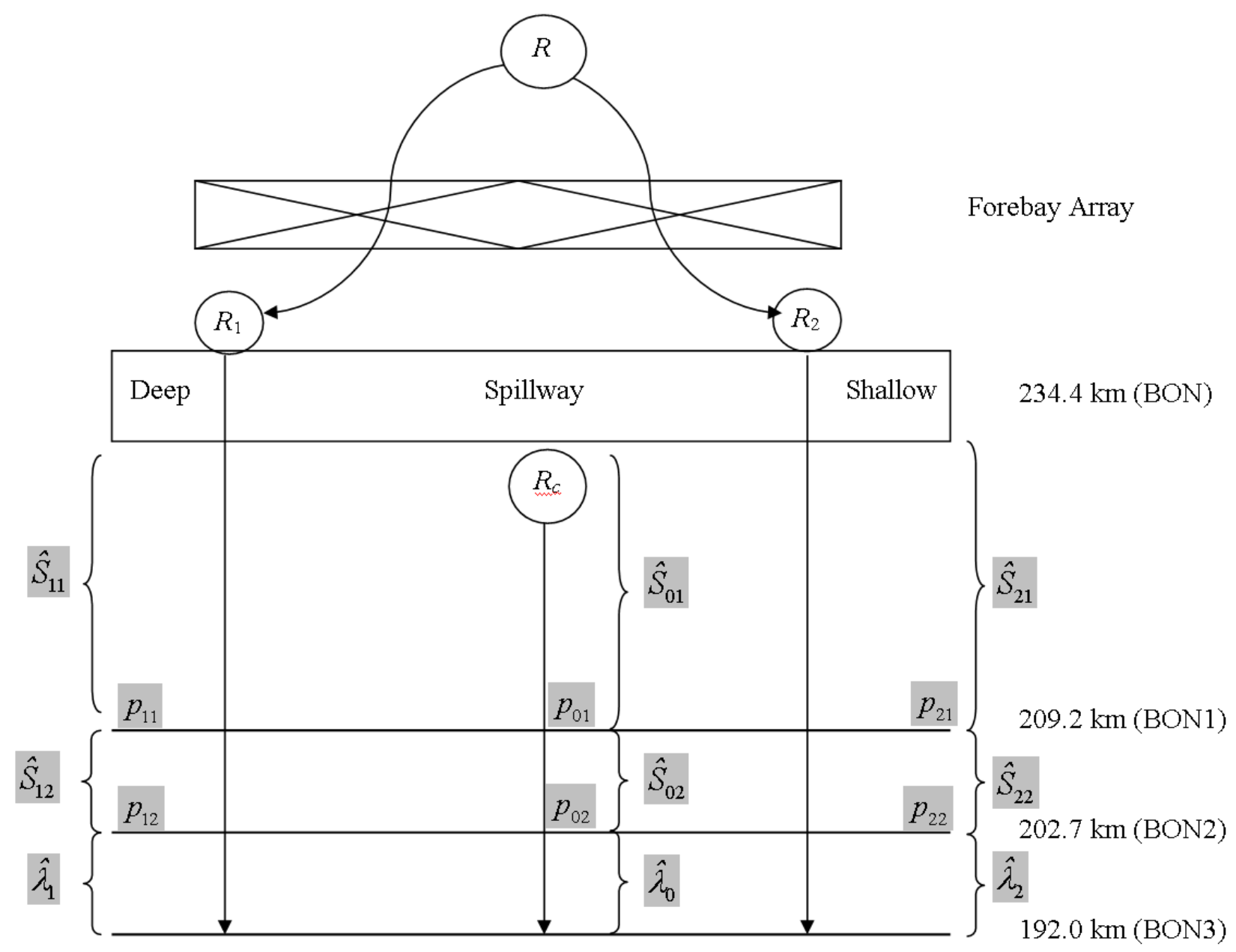

Figure 2.15. Schematic of Spillway Survival Studies at Bonneville Dam in 2007, Showing Virtual Deep and Shallow Deflector Bay Releases and Corresponding Control Releases in the Tailrace. (Terms are defined in Section 2.9.2.)

\subsubsection{Estimation of Relative Survival for Shallow and Deep Deflector Bays}

Within each trial, smolts known to have passed through shallow versus deep flow deflector spill bays were compared using the paired-release (PR) models of Burnham et al. (1987). For each trial, the RS of smolt passage through deep to shallow flow deflectors was estimated as follows:

$$
\mathrm{RS}_{\text {Deep } / \text { Shallow }}=\frac{\hat{S}_{\text {Deep }}}{\hat{S}_{\text {Shallow }}}
$$

The estimates of RS were calculated for the first downstream reach between Bonneville Dam and the primary array and for the second reach between the primary and secondary arrays (Figure 2.15). With three detector locations, there were eight $\left(2^{3}\right)$ possible capture histories used in modeling the release-recapture data from each release group. The release-recapture model had the following parameters: 
$S_{1 j}=$ survival in the first reach for the $j$ th treatment group $(j=1,2)$

$p_{1 j}=$ probability of being detected at the first downstream detection array, given that fish survived to that location for the $j$ th treatment group $(j=1,2)$

$S_{2 j}=$ conditional probability of survival to the second reach, given that fish survived the first reach for the $j$ th treatment group $(j=1,2)$

$p_{2 j}=$ probability of being detected at the second downstream detection array, given that fish survived to that location for the $j$ th treatment group $(j=1,2)$

$\lambda_{j}=$ joint probability of a fish surviving to and being detected at the third downstream detection array, given that fish survived to the second detection array for the $j$ th treatment group $(j=1,2)$.

A joint likelihood model was used to estimate these parameters and estimate the relative survival of fish through the deep flow $\left(\hat{S}_{i 1}\right)$ versus shallow flow deflector $\left(\hat{S}_{i 2}\right)$ spill bays, i.e.,

$$
\widehat{\mathrm{RS}}_{1}=\frac{\hat{S}_{11}}{\hat{S}_{12}}
$$

for reach 1 and

$$
\widehat{\mathrm{RS}}_{2}=\frac{\hat{S}_{21}}{\hat{S}_{22}}
$$

for reach 2.

The variance of the RS can be estimated by the expression

$$
\begin{aligned}
\widehat{\operatorname{Var}}\left(\widehat{\mathrm{RS}}_{i}\right) & =\left(\frac{\hat{S}_{i 1}}{\hat{S}_{i 2}}\right)^{2}\left[\frac{\widehat{\operatorname{Var}}\left(\hat{S}_{i 1}\right)}{\hat{S}_{i 1}^{2}}+\frac{\widehat{\operatorname{Var}}\left(\hat{S}_{i 2}\right)}{\hat{S}_{i 2}^{2}}\right] \\
& =\widehat{\mathrm{RS}}_{i}^{2}\left[\widehat{\mathrm{CV}}\left(\hat{S}_{i 1}\right)^{2}+\widehat{\mathrm{CV}}\left(\hat{S}_{i 2}\right)^{2}\right]
\end{aligned}
$$

and where

$$
\widehat{\mathrm{CV}}(\hat{\theta})=\frac{\sqrt{\widehat{\operatorname{Var}}(\hat{\theta})}}{\hat{\theta}}
$$


Across $n$ trials, a weighted average of the trial-specific relative survival estimates was calculated of the form

$$
\widehat{\mathrm{RS}}_{i}=\frac{\sum_{j=1}^{n} w_{j} \widehat{\mathrm{RS}}_{i j}}{\sum_{j=1}^{n} w_{j}}
$$

where the weights were calculated as

$$
w_{j}=\frac{1}{\left[\frac{\operatorname{Var}\left(\widehat{\mathrm{RS}}_{i j}\right)}{\left(\widehat{\mathrm{RS}}_{i j}\right)^{2}}\right]}=\frac{1}{\mathrm{CV}\left(\widehat{\mathrm{RS}}_{i j}\right)^{2}}
$$

Using the weights based on the inverse of the $\mathrm{CV}^{2}$ eliminates the correlation between the estimates of $\mathrm{RS}$ and their variance estimates. The variance of the weighted average was calculated as

$$
\operatorname{Var}\left(\widehat{\mathrm{RS}_{i}}\right)=\frac{\sum_{j=1}^{n} w_{j}\left(\mathrm{RS}_{i j}-\widehat{\mathrm{RS}}_{i}\right)^{2}}{\sum_{j=1}^{n} w_{j}(n-1)}
$$

\subsubsection{Test of Spillway Survival Differences}

Analysis of deviance (ANODEV) procedures (McCullagh and Nelder 1989) were used to test the null hypothesis that survival through the deep flow deflector spill bays $\left(S_{D F}\right)$ was less than or equal to survival through the shallow flow deflector $\left(S_{S F}\right)$ spill bays:

$$
\mathrm{H}_{\mathrm{o}}: \mathrm{S}_{\mathrm{DF}} \leq \mathrm{S}_{\mathrm{SF}}
$$

versus the alternative hypothesis

$$
\mathrm{H}_{\mathrm{a}}: \mathrm{S}_{\mathrm{DF}}>\mathrm{S}_{\mathrm{SF}}
$$

at $\alpha=0.05$, one-tailed. The ANODEV was used because it took into account the variation in response between replicate release groups conducted over the season. The ANODEV was used to assess whether spill-bay effects persisted through not only the first downriver reach but also through the second reach. Separate analyses were performed for the yearling and subyearling Chinook salmon trials. Note that testing for spill deflector bay differences in survival, did not require reference-release groups. Reference releases are only required for estimating absolute passage survival. 


\subsubsection{Estimating Absolute Spillway Passage Survival}

The tailrace releases below Bonneville Dam were used in conjunction with spill-bay releases to estimate absolute spillway passage survival (Figure 2.15). The ratio of reach survivals for known spillbay-passed fish to tailrace-released fish were used to estimate survival through the spillway.

The same PR model described in Section 2.9.2 also was used in estimating absolute spillway survival. Passage survival was estimated on a per-trial basis and a weighted average (Equation 2.3) was calculated across trials with an associated variance estimator (Equation 2.4).

A PR design was used to estimate spillway passage survival at BON2. The three downstream arrays (Figure 2.15) produced eight $\left(2^{3}\right)$ possible capture histories. The joint likelihood for the model was formulated as follows:

$$
\begin{aligned}
L= & \left(\begin{array}{c}
R_{1} \\
\underset{\sim}{n}
\end{array}\right)\left(S_{11} p_{11} S_{12} p_{12}\right)^{n_{111}}\left(S_{11}\left(1-p_{11}\right) S_{12} p_{12} \lambda_{1}\right)^{n_{011}} \\
& \cdot\left(S_{11} p_{11} S_{12}\left(1-p_{12}\right) \lambda_{1}\right)^{n_{101}}\left(S_{11}\left(1-p_{11}\right) S_{12}\left(1-p_{12}\right) \lambda_{1}\right)^{n_{011}} \\
& \cdot\left(S_{11} p_{11} S_{12} p_{12}\left(1-\lambda_{1}\right)\right)^{n_{110}}\left(S_{11}\left(1-p_{11}\right) S_{12} p_{12}\left(1-\lambda_{1}\right)\right)^{n_{010}} \\
& \cdot\left(S_{11} p_{11}\left(\left(1-S_{12}\right)+S_{12}\left(1-p_{12}\right)\left(1-\lambda_{1}\right)\right)\right)^{n_{100}} \\
& \cdot\left(\left(1-S_{11}\right)+S_{11}\left(1-p_{11}\right)\left(\left(1-S_{12}\right)+S_{12}\left(1-p_{12}\right)\left(1-\lambda_{1}\right)\right)\right)^{n_{000}} \\
& \cdot\left(R_{2}\right)\left(S_{21} p_{21} S_{22} p_{22} \lambda_{2}\right)^{m_{111}}\left(S_{21}\left(1-p_{21}\right) S_{22} p_{22} \lambda_{2}\right)^{m_{011}} \\
& \cdot\left(S_{21} p_{21} S_{22}\left(1-p_{22}\right) \lambda_{2}\right)^{m_{101}}\left(S_{21}\left(1-p_{21}\right) S_{22}\left(1-p_{22}\right) \lambda_{2}\right)^{m_{011}} \\
& \cdot\left(S_{21} p_{21} S_{22} p_{22}\left(1-\lambda_{2}\right)\right)^{m_{110}}\left(S_{21}\left(1-p_{21}\right) S_{22} p_{22}\left(1-\lambda_{2}\right)\right)^{m_{010}} \\
& \cdot\left(S_{21} p_{21}\left(\left(1-S_{22}\right)+S_{22}\left(1-p_{22}\right)\left(1-\lambda_{2}\right)\right)\right)^{m_{100}} \\
& \cdot\left(\left(1-S_{21}\right)+S_{21}\left(1-p_{21}\right)\left(\left(1-S_{22}\right)+S_{22}\left(1-p_{22}\right)\left(1-\lambda_{2}\right)\right)\right)^{m_{000}},
\end{aligned}
$$

where $\underset{\sim}{n}$ and $\underset{\sim}{m}$ are the vector of counts associated with the downstream capture histories of releases $R_{1}$ and $R_{2}$, respectively. For example, $n_{101}$ would be the number of $R_{1}$ fish detected at BON1, not detected at BON2, and subsequently detected at BON3 (Figure 2.15).

Spillway survival was estimated as the ratio

$$
\hat{S}_{\text {Spill }}=\frac{\hat{S}_{11}}{\hat{S}_{21}}
$$


with associated variance estimator

$$
\widehat{\operatorname{Var}}\left(\hat{S}_{\text {Spill }}\right)=\hat{S}_{\text {Spill }}^{2}\left[\frac{\widehat{\operatorname{Var}}\left(\hat{S}_{11}\right)}{\hat{S}_{11}^{2}}+\frac{\widehat{\operatorname{Var}}\left(\hat{S}_{21}\right)}{\hat{S}_{21}^{2}}\right]
$$

Based on tag-life studies, the tag-life data were fit to a Weibull distribution of the form

$$
f(x)=e^{-\left(\frac{x-\gamma}{\eta}\right)^{\beta}}\left(\frac{\beta}{\eta^{\beta}}\right)(x-\gamma)^{\beta-1}
$$

to model tag life. Based on the results of the tag-life study, the need for a tag-life correction to the survival estimates was determined. If all study fish exited the study (i.e., passed BON3) prior to the time of the first tag failure, no tag-life correction was performed. Otherwise, an adjustment to the survival estimates was performed.

In the case of potential tag failure, additional parameters were added to the above model (Equation 2.6) based on methods of Townsend et al. (2006). Table 2.6 presents the expected probabilities of occurrence for each of the possible capture histories under tag failure where:

$L_{11}=$ probability a tag from release $R_{1}$ survived the first reach

$L_{12}=$ probability a tag from release $R_{1}$ survived both reach 1 and reach 2

$L_{13}=$ probability a tag from release $R_{1}$ survived reaches 1 through 3

$L_{21}=$ probability a tag from release $R_{2}$ survived the first reach

$L_{22}=$ probability a tag from release $R_{2}$ survived both reach 1 and reach 2

$L_{23}=$ probability a tag from release $R_{1}$ survived reaches 1 through 3 .

The joint likelihood was expressed as

$$
L=L\left(S_{11}, p_{11}, S_{12}, p_{12}, \lambda_{1} \mid R_{1}, \underset{\sim}{n} \underset{\sim 1}{L}\right) \cdot L\left(S_{21}, p_{21}, S_{22}, \underset{p_{22}}{\lambda_{2}} \mid R_{2}, \underset{\sim}{m} \underset{\sim 2}{L_{2}}\right)
$$

The estimates of survival derived from the likelihood model (Equation 2.10) should be more reliable because they took into account tag failure and tag-life probabilities less than one.

The estimates of the survival and capture parameters in the likelihood model (Equation 2.10) were calculated, treating the estimates of tag life (i.e., $\hat{L}_{11}, \hat{L}_{12}, \hat{L}_{21}$, and $\hat{L}_{22}$ ) as known constants. However, to calculate a realistic variance estimator for the survival parameters, the error in the estimation of the taglife probabilities was incorporated into an overall variance calculation. The variance of the survival estimates was calculated using the total variance formula 


$$
\operatorname{Var}\left(\hat{S}_{P R}\right)=\operatorname{Var}_{\hat{\underline{L}}}\left[E\left(\hat{S}_{P R} \mid \hat{L}\right)\right]+E_{\hat{\sim}}\left[\operatorname{Var}\left(\hat{S}_{P R} \mid \hat{L}\right)\right]
$$

The above variance was therefore estimated in stages using the expression

$$
\operatorname{Var}\left(\hat{S}_{P R}\right)=s_{\hat{S}_{P R} \mid \hat{\sim}}^{2}+\operatorname{Var}\left(\hat{S}_{P R} \mid \underset{\sim}{\hat{L}}\right)
$$

The second term in Equation 2.12 was derived from the maximum likelihood model (Equation 2.10) conditioning on the tag-life probabilities (i.e., $\underset{\sim}{\sim}$ ). The first variance component in Equation 2.12 was calculated using bootstrap resampling techniques (Efron and Tibshirani 1993). Alternative estimates of $\hat{L}$ were computed by bootstrapping both the observed tag-life data and travel-time data. For each estimated vector of tag-life parameters, survival was estimated using the likelihood model (Equation 2.12). One thousand bootstrap estimates of the tag-life parameters were calculated along with the corresponding conditional maximum likelihood estimates of survival.

The first variance component in Equation 2.12 was then estimated by the quantity

$$
s_{\hat{S}_{P R} \mid \hat{L}}^{2}=\frac{\sum_{b=1}^{1000}\left(\hat{S}_{b}-\hat{\bar{S}}\right)^{2}}{(1000-1)}
$$

where $\hat{S}_{b}=$ the $b$ th bootstrap estimate of survival $(b=1, \ldots, 1000)$

$$
\hat{\bar{S}}=\frac{\sum_{b=1}^{1000} \hat{S}_{b}}{1000}
$$

Table 2.6. Detection Histories and Expected Probabilities of Occurrences for Upstream $\left(R_{1}\right)$ and Downstream $\left(R_{2}\right)$ Releases in the Presence of Tag Failure

\begin{tabular}{ccc} 
Release & $\begin{array}{c}\text { Detection } \\
\text { History }\end{array}$ & Expected Probabilities \\
\hline$R_{1}$ & 111 & $S_{11} p_{11} S_{12} p_{12} \lambda_{1} L_{13}$ \\
& 011 & $S_{11}\left(1-p_{11}\right) S_{12} p_{12} \lambda_{1} L_{13}$ \\
& 101 & $S_{11} p_{11} S_{12}\left(1-p_{12}\right) \lambda_{1} L_{13}$ \\
& & $S_{11}\left(1-p_{11}\right) S_{12}\left(1-p_{12}\right) \lambda_{1} L_{13}$ \\
& 110 & $S_{11} p_{11} S_{12} p_{12}\left(L_{12}-L_{13} \lambda_{1}\right)$ \\
\hline
\end{tabular}


Table 2.6. (contd)

\begin{tabular}{lll} 
Release & $\begin{array}{c}\text { Detection } \\
\text { History }\end{array}$ & \multicolumn{1}{c}{ Expected Probabilities } \\
\hline 010 & $S_{11}\left(1-p_{11}\right) S_{12} p_{12}\left(L_{12}-L_{13} \lambda_{1}\right)$ \\
& 100 & $S_{11} p_{11}\left[\left(L_{11}-L_{12} S_{12}\right)+S_{12}\left(1-p_{12}\right)\left(L_{12}-L_{13} \lambda_{1}\right)\right]$ \\
& 000 & $\left(1-L_{11} S_{11}\right)+S_{11}\left(1-p_{11}\right)\left[\left(L_{11}-L_{12} S_{12}\right)+S_{12}\left(1-p_{12}\right)\left(L_{12}-L_{13} \lambda_{1}\right)\right]$ \\
$R_{2}$ & 111 & $S_{21} p_{21} S_{22} p_{22} \lambda_{2} L_{23}$ \\
& 011 & $S_{21}\left(1-p_{21}\right) S_{22} p_{22} \lambda_{2} L_{23}$ \\
& 101 & $S_{21} p_{21} S_{22}\left(1-p_{22}\right) \lambda_{2} L_{23}$ \\
001 & $S_{21}\left(1-p_{21}\right) S_{22}\left(1-p_{22}\right) \lambda_{2} L_{23}$ \\
110 & $S_{21} p_{21} S_{22} p_{22}\left(L_{22}-L_{23} \lambda_{2}\right)$ \\
010 & $S_{21}\left(1-p_{21}\right) S_{22} p_{22}\left(L_{22}-L_{23} \lambda_{2}\right)$ \\
100 & $S_{21} p_{21}\left[\left(L_{21}-L_{22} S_{22}\right)+S_{22}\left(1-p_{22}\right)\left(L_{22}-L_{23} \lambda_{2}\right)\right]$ \\
000 & $\left(1-L_{21} S_{21}\right)+S_{21}\left(1-p_{21}\right)\left[\left(L_{21}-L_{22} S_{22}\right)+S_{22}\left(1-p_{22}\right)\left(L_{22}-L_{23} \lambda_{2}\right)\right]$ \\
&
\end{tabular}

Unless otherwise noted, straight lines and curves on graphs are linear and quadratic fits using ordinary least-squares regression. We only considered the use of the next higher-order polynomials when $\mathrm{r}^{2}$ increased by $\geq 0.05$. 



\subsection{Results}

The 2007 outmigration conditions described below precede the discussion of study results, which include the detection of dead fish by survival arrays, detection performance of the spillway cabled array, downstream arrays, egress rates, detection and survival of yearling Chinook salmon in spring and subyearling Chinook salmon in summer. Tests of survival-model assumptions are also described in this section.

\subsection{Outmigration Conditions}

The description of environmental conditions during the 2007 study provided here includes seasonal changes in river and spill discharge, water temperature, and tailrace elevation. Seasonal trends in discharge and temperature were plotted alongside averages for the previous 10 years. We also looked at the species composition of all juvenile salmonids in B2 JMF samples, and plotted length frequencies of tagged and un-tagged juvenile Chinook salmon.

\subsubsection{Project Discharge, Temperature, and Tailrace Elevation}

The 10-year (1997 to 2006) average project and spill discharges were plotted alongside the 2007 discharge from Bonneville Dam by day (Figure 3.1). During spring, most tagged fish were released when total project and spill discharge were similar to the 10-year average, except during the last week when 2007 values were lower than the 10-year average. When fish were released in summer, total discharge was below the 10 -year average, but spill discharge was slightly above it.

Forebay water temperatures in 2007 were within one degree of the 10-year average when fish were released in spring and most of summer (Figure 3.2). During the last three days of summer 2007, water temperatures ranged from 1.1 to 1.2 degrees higher than the 10-year average. The highest temperature observed during fish releases was $20.5^{\circ} \mathrm{C}$.

Tailrace elevations were mostly more than $5.5 \mathrm{~m}$ above MSL throughout spring but averaged closer to $4.9 \mathrm{~m}$ above MSL in summer (Figure 3.3). This means that the depth of water over shallow flow deflectors exceeded $1.23 \mathrm{~m}$ in spring but often was $0.63 \mathrm{~m}$ or less in summer. In contrast, water depths over deep flow deflectors averaged $3.37 \mathrm{~m}$ in spring and $2.77 \mathrm{~m}$ in summer. 


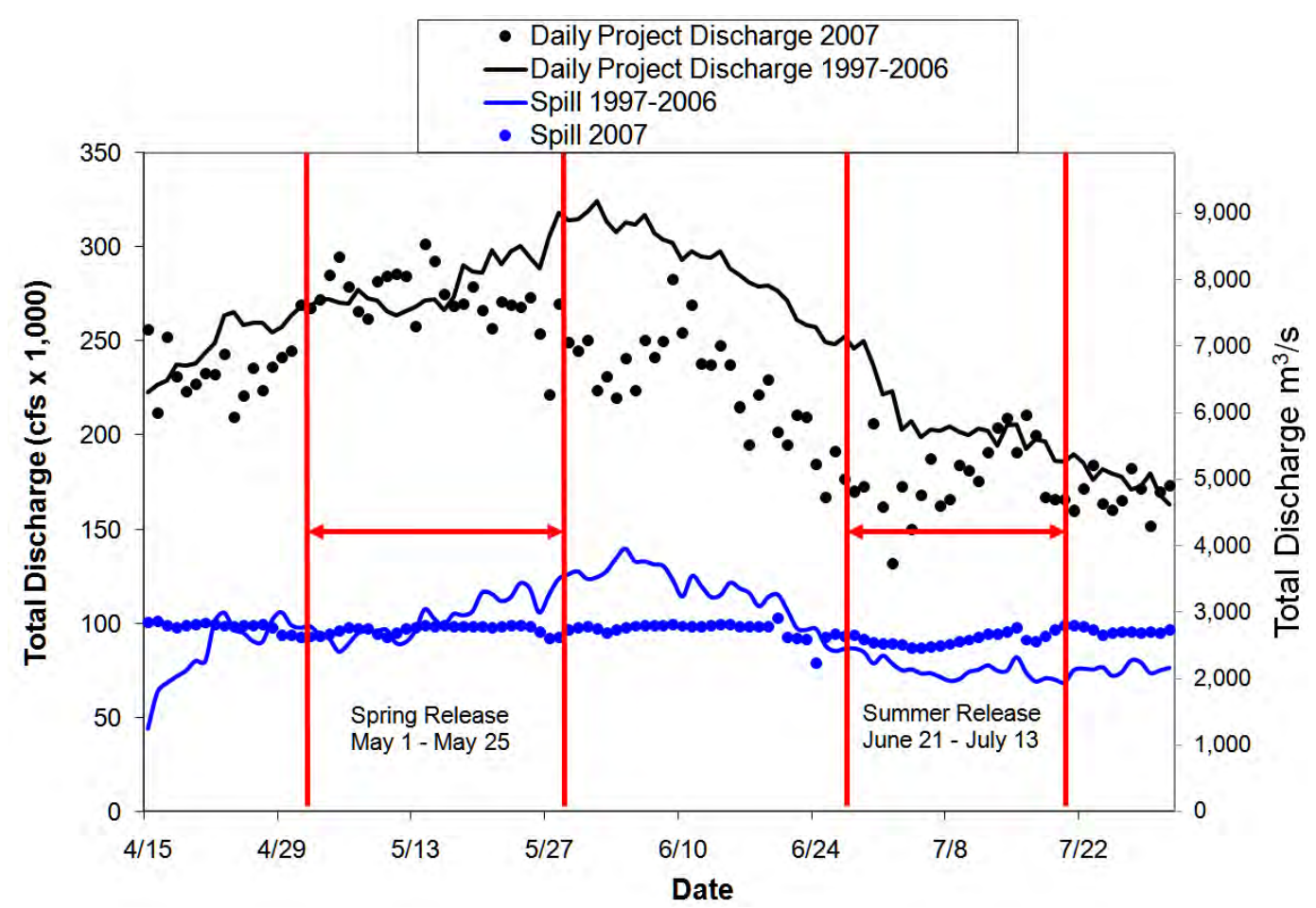

Figure 3.1. Ten-Year Average Daily Project Discharge (1997-2006) Versus 2007 Daily Project Discharge for the Bonneville Project. Discharge units are in English units on the primary vertical axis and in metric units on the secondary vertical axis.

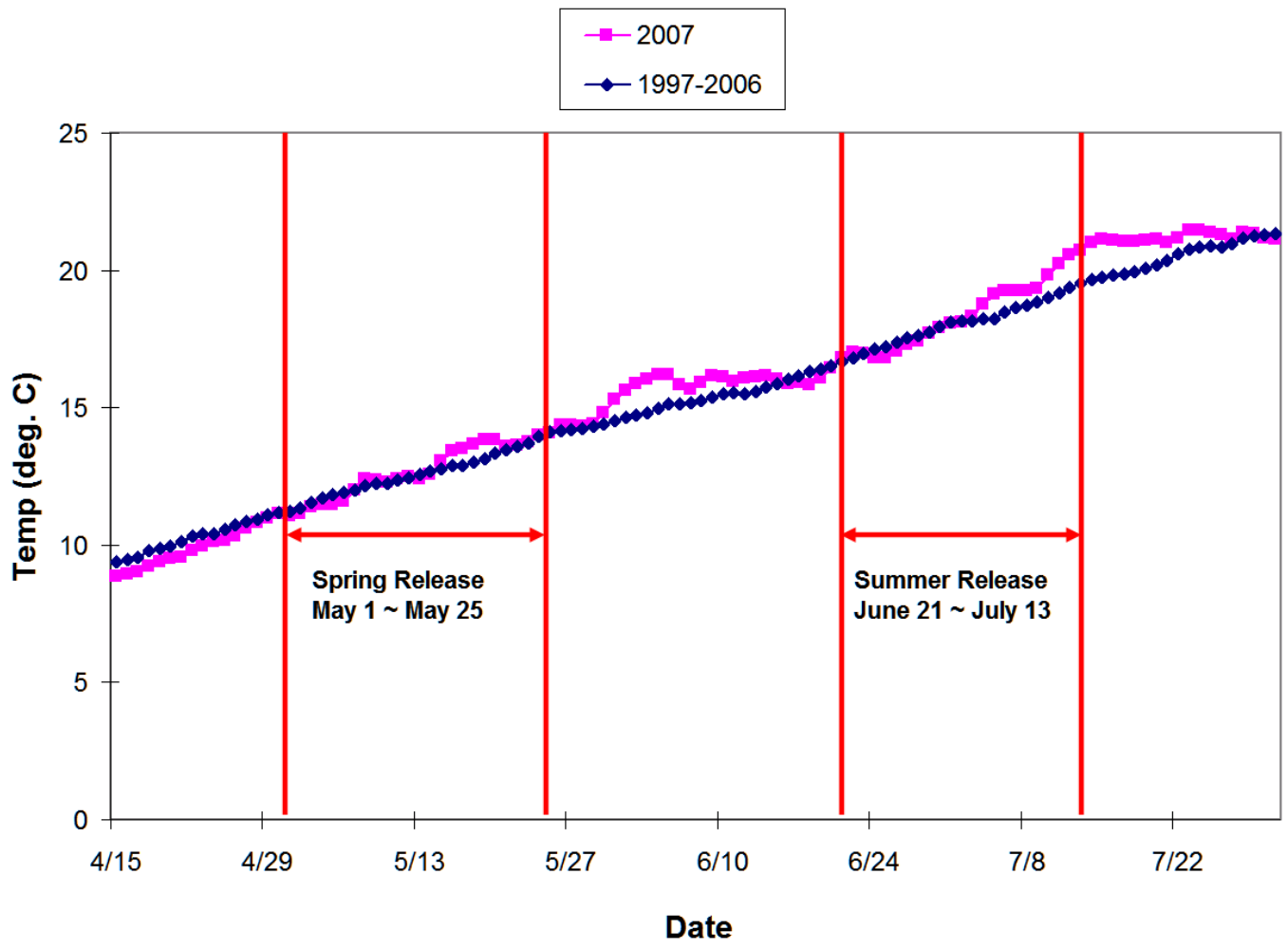

Figure 3.2. Ten-Year Average Forebay Water Temperature $\left({ }^{\circ} \mathrm{C}\right)$ Versus 2007 Water Temperature by Day (April 15 through July 31) at Bonneville Dam 


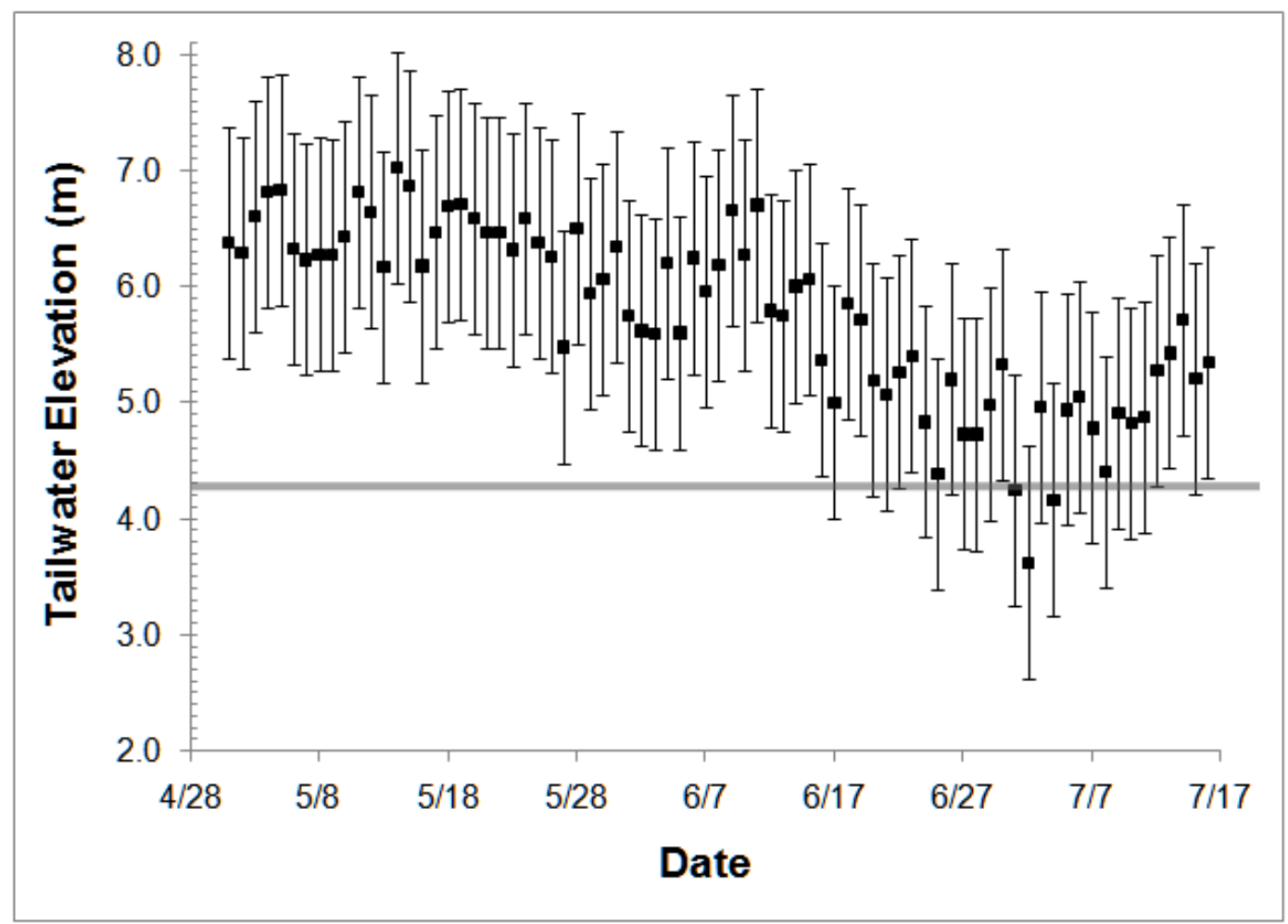

Figure 3.3. Mean Tailrace Elevations in Meters Above MSL in Spring and Summer 2007. The horizontal reference line at $4.267 \mathrm{~m}$ above MSL marks the elevation of shallow flow deflectors. Error bars indicate the daily range.

\subsubsection{Run Timing and Smolt Species Composition}

The species composition of all downstream migrants arriving at Bonneville Dam was calculated using data obtained from the B2 JMF and reported at the DART website (Figure 3.4). Both hatchery and wild stock were combined to display total salmonid run composition for 2007. Spring collection for this study was conducted at the B2 JMF from 29 April through to 23 May, 2007. The composition of species arriving at the juvenile bypass during our collection period was inclusive of the major migration peak in spring for all downstream migrants. Juvenile salmonids arriving at the B2 JMF in spring included 50\% yearling Chinook salmon (Oncorhynchus tshawytscha), 16\% coho salmon (O. kisutch), 3\% sockeye salmon (O. nerka), 6\% steelhead (O. mykiss), and 25\% subyearling Chinook Salmon. Summer collection was from June 19 to July 11, 2006. For summer, subyearling Chinook salmon was the dominant migrant. The peak of the subyearling Chinook salmon migration occurred during the middle of our collection period. Although specific data were not available from DART, over $54 \%$ of the collected subyearlings used as treatment fish, both hatchery and wild stock, were unclipped. 


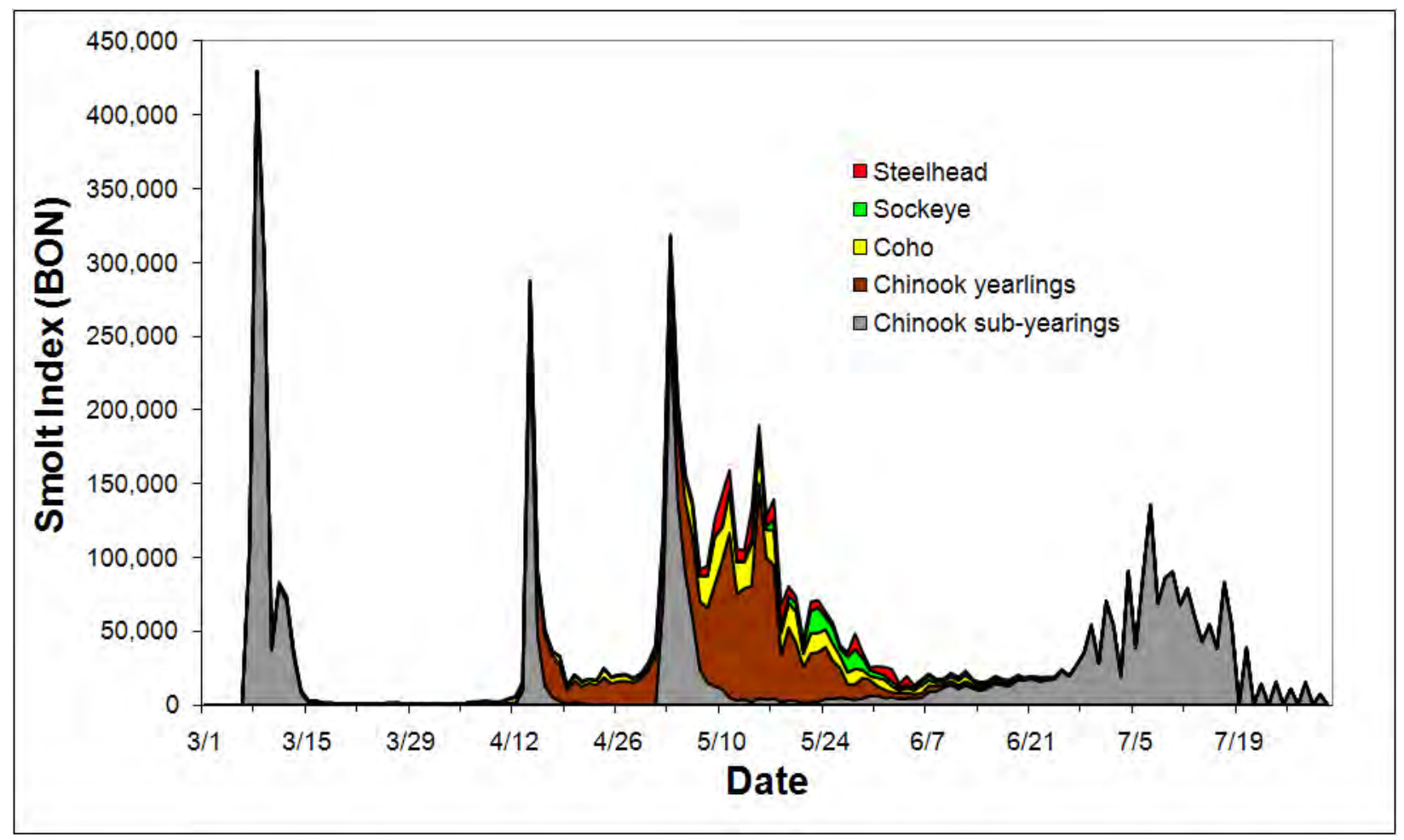

Figure 3.4. Smolt Monitoring Program Passage Index for March 1 through July 31, 2007, based on Data from the Bonneville Juvenile Monitoring Facility. Data were obtained from the Fish Passage Center Web Site: (http://www.fpc.org/smolt/historicsmpsubmitdata.html).

\subsubsection{Fish Rejection Rates and Length Frequencies During Tagging}

We rejected a low percentage of sampled fish for tagging based on condition criteria described in Section 2.0 (Methods). The daily average rejection rate was 3\% $\pm 0.3 \%$ SE in spring (totaling 151 out of 4994 yearlings) and $3.6 \% \pm 0.64 \%$ SE in summer (totaling 210 out of 5882 subyearlings). No yearlings were excluded from tagging based on the 95-mm minimum length criterion. In contrast, the 95-mm minimum length excluded $39.5 \%$ of subyearlings from tagging.

We compared the frequency of lengths of 3000 tagged yearling Chinook salmon with those of fish sampled at the B2 JMF in spring, and yearlings of all lengths were tagged in proportion to their relative abundance in the sampled run (Figure 3.5). The mean and median lengths of yearling Chinook tagged in spring (144 and $142 \mathrm{~mm}$, respectively) were within $1 \mathrm{~mm}$ of respective estimates for fish sampled at the JMF. 


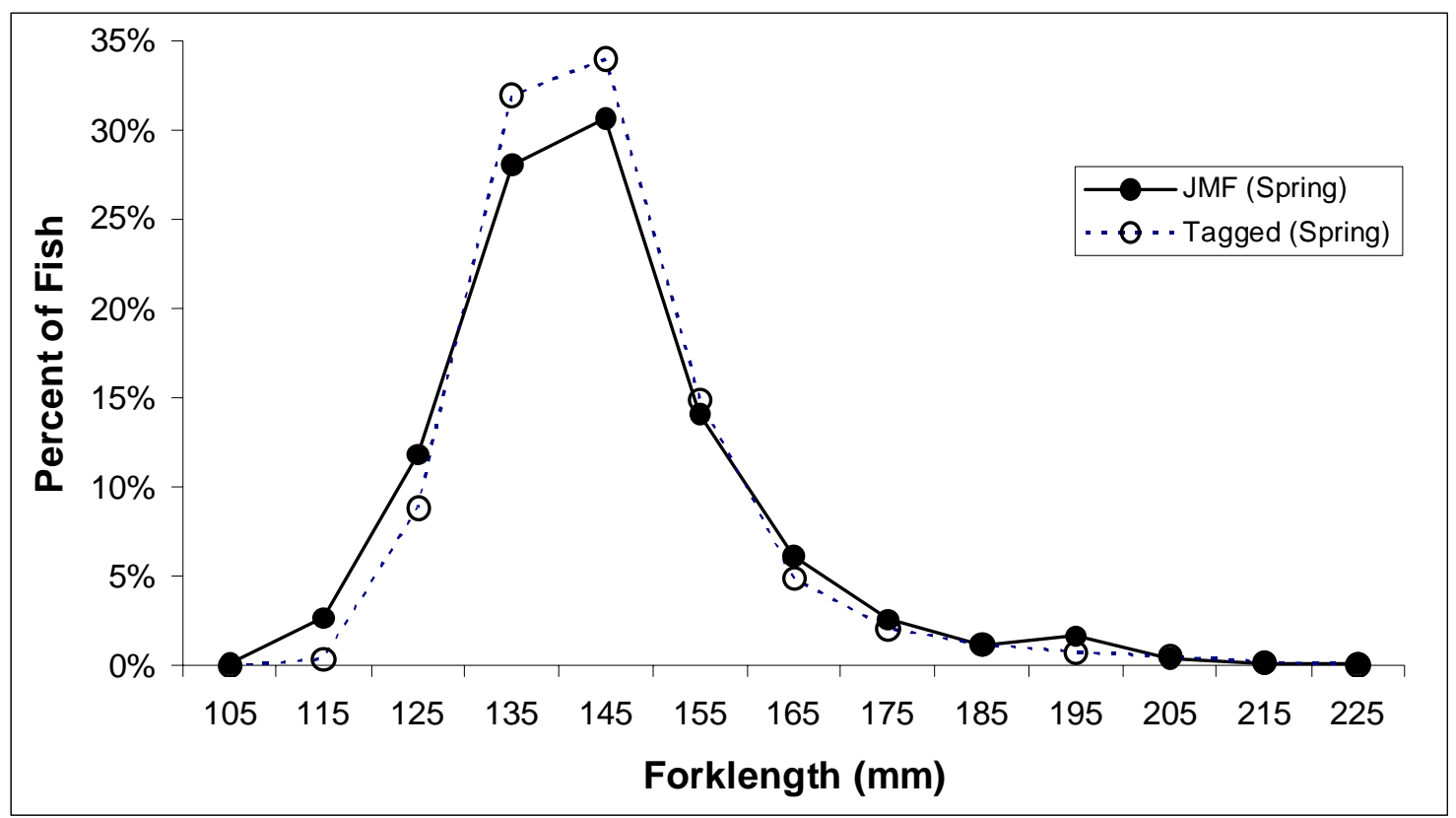

Figure 3.5. Length Frequency of 3000 Tagged and 1364 Untagged Run-of-River Yearling Chinook Salmon During Spring Tagging (4/30-5/24) at the B2 JMF in 2007

The lower end of the distribution of length frequencies of 2996 tagged subyearling Chinook salmon was truncated at $95 \mathrm{~mm}$ relative to the length frequency distribution of subyearlings handled at the B2 JMF in summer (Figure 3.6). Only 3.4\% of the untagged population was $<80 \mathrm{~mm}$ long, but 39.5\% of the subyearling run was between $80 \mathrm{~mm}$ and $95 \mathrm{~mm}$ and was not tagged.

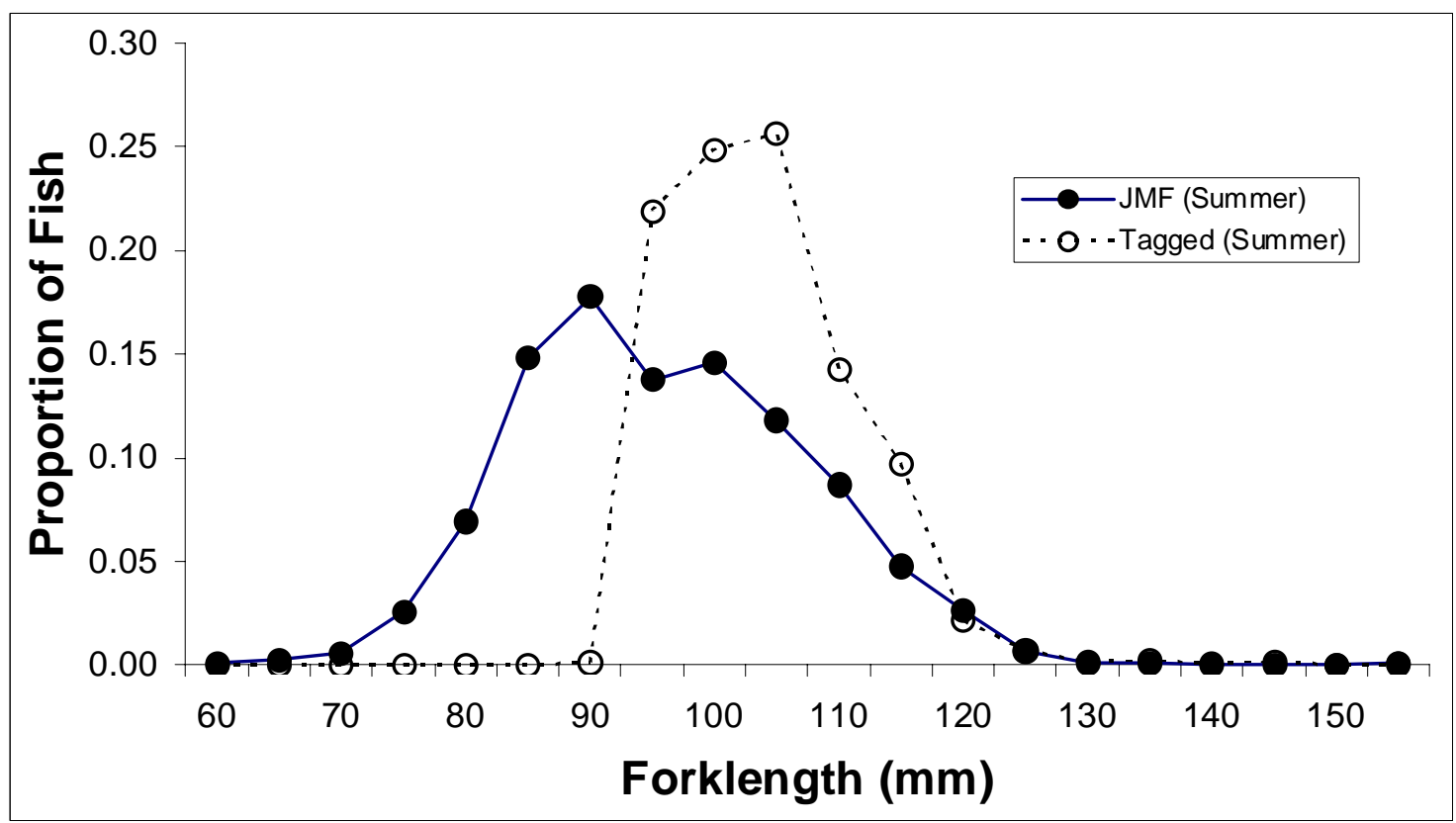

Figure 3.6. Length Frequency of 2996 Tagged and 1301 Untagged Subyearling Chinook Salmon During Summer Tagging (6/20-7/12) at the B2 JMF in 2007 
Additional information on fish, tag codes, release locations, release times, and dam operations is provided in Appendix A. Tables A.1 and A.2 include a summary of numbers and percentages of tagged fish released alive and dead (including numbers intentionally sacrificed) by date in spring and summer, respectively. Tables A.3 and A.4 describe comma-separated variable (CSV) files for spring and summer that are on a CD that accompanies printed versions of this report. The CSV files contain detailed data associated with every fish that was tagged and released at or below John Day Dam including season, release date, release time, PIT-tag code, acoustic-tag code, acoustic-tag activation date, fork length, weight, mortality status, and release location, as well as all dam operations at the time of release.

\subsection{Detection of Dead Fish by Survival Arrays}

We detected one dead tagged fish released in the spillway forebay on the primary and secondary survival arrays, as well as on four other arrays downstream to within $42 \mathrm{~km}$ of Astoria, Oregon, in spring 2007. We believe the fish was dead because a slow egress rate $(0.01 \mathrm{~m} / \mathrm{s})$ produced a 252-hour travel time to the egress array $9 \mathrm{~km}$ below Bonneville Dam and was followed by much faster rates ranging from 0.71 to $1.81 \mathrm{~m} / \mathrm{s}$ in subsequent reaches (Table 3.1). For live fish, the median travel time from the dam to the egress array was 1.4 hours and from the dam to the primary array it was just 7.4 hours.

Table 3.1. Detection Sequence for a Dead Tagged Fish Released on May 25 in the Spillway Forebay

\begin{tabular}{cccccc}
\hline Dam/Array & River $(\mathrm{km})$ & $\begin{array}{c}\text { Kilometer from } \\
\text { Previous Location }\end{array}$ & $\begin{array}{c}\text { Elapsed } \\
\text { Time }(\mathrm{hr})\end{array}$ & $\begin{array}{c}\text { Mean Rate } \\
(\mathrm{m} / \mathrm{s})\end{array}$ & $\begin{array}{c}\text { Number of Tag } \\
\text { Decodes }\end{array}$ \\
\hline BON & 234.0 & & & & \\
Egress & 225.0 & 9.0 & 252.0 & 0.01 & 31 \\
Primary & 209.2 & 15.8 & 4.0 & 1.10 & 4 \\
Secondary & 202.7 & 6.5 & 1.0 & 1.81 & 0 \\
Tertiary & 192.0 & 10.7 & & & 5 \\
Kalama & 120.7 & 71.3 & 28.0 & 0.71 & 21 \\
Oak Point 1 & 86.6 & 34.1 & 6.5 & 1.46 & 41 \\
Oak Point 2 & 83.7 & 2.9 & 1.0 & 0.81 & 4 \\
Cathlamet & 57.0 & 26.7 & 5.0 & 1.48 & 4 \\
\hline
\end{tabular}

\subsection{Detection Performance of the Spillway Cabled Array}

The cabled array in the spillway forebay detected no tags during the first two weeks of spring, but detection began to increase during the third week because fabricated baffles were added to individual hydrophones on piers to reduce noise coming from the direction of spill gates downstream of hydrophones, and detection rates gradually increased from late spring through summer (Figure 3.7). Star clusters of hydrophones were the only systems deployed during the first week, but we added hydrophones 
to 16 of 18 piers during the second week. Background sound levels originating from spill gates were detected by all hydrophones and were very high throughout spring and summer. Two versions of acoustic tag decoder software were used during the study, and the second version (TDOA6) that was first available in spring 2008, decoded 1.7 times more tag signals from archived waveform data than the original version (TDAO2; see Figure 3.7). Processing of over 55 terabytes of waveform data collected in spring and summer took about 3 months for each version of the decoder, even with 12 fast microcomputers.

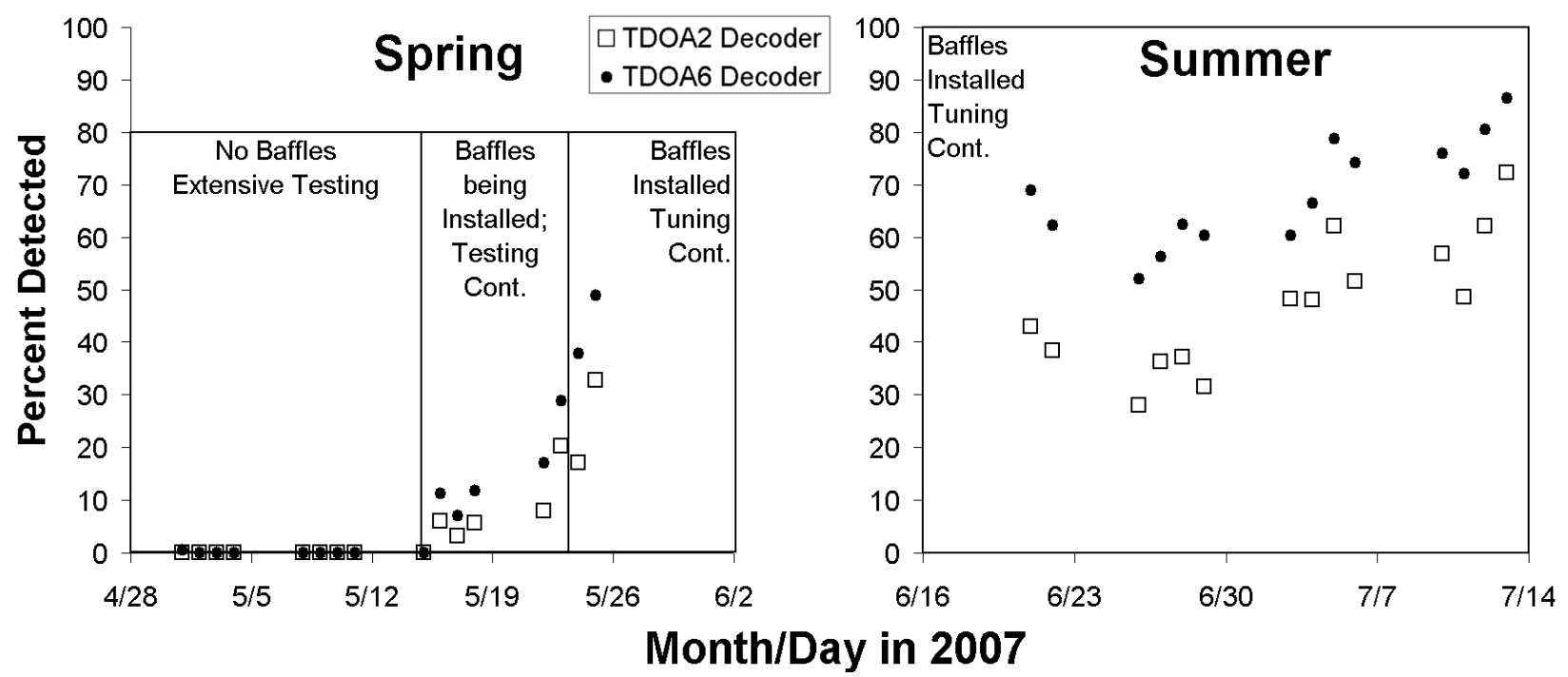

Figure 3.7. Percent of Acoustic Tags in Spillway Forebay-Released Fish Detected and Decoded at Least Four Times in Two Minutes in Spring and Summer 2007. The TDOA2 and TDOA6 versions of decoder software were completed and used to process waveform data in fall 2007 and spring 2008, respectively.

\subsection{Detection Performance of Downstream Arrays}

We examined the distribution of detections among autonomous nodes deployed in each array (Figure 3.8). Mid-river nodes or those near the navigation channel usually detected more acoustic tags in yearling and subyearling Chinook salmon than nodes in shallow areas away from the navigation channel or in backwater areas. The deepest and usually fastest part of the river channel was closest to nodes 1 and 2 on the egress array, nodes 2,3 , and 4 on the primary array, nodes 3,4 , and 5 on the secondary array, and nodes 3 and 4 on the tertiary array.

Another indicator of autonomous node performance is the frequency of multi-node detections within arrays. The egress array (BON0) and primary survival array (BON1) had more tag detections on multiple nodes than did the secondary (BON2) or tertiary (BON3) arrays (Figure 3.9). The percent of tag detections on two or more nodes was $95.8 \%$ in spring and $76.9 \%$ in summer for the egress array. For the primary array, $60.7 \%$ of spring tags and $87 \%$ of summer tags were detected on two or more nodes. In contrast, percent detections on two or more nodes were $<21.3 \%$ in spring and $<54 \%$ in summer at arrays BON2 and BON3. 


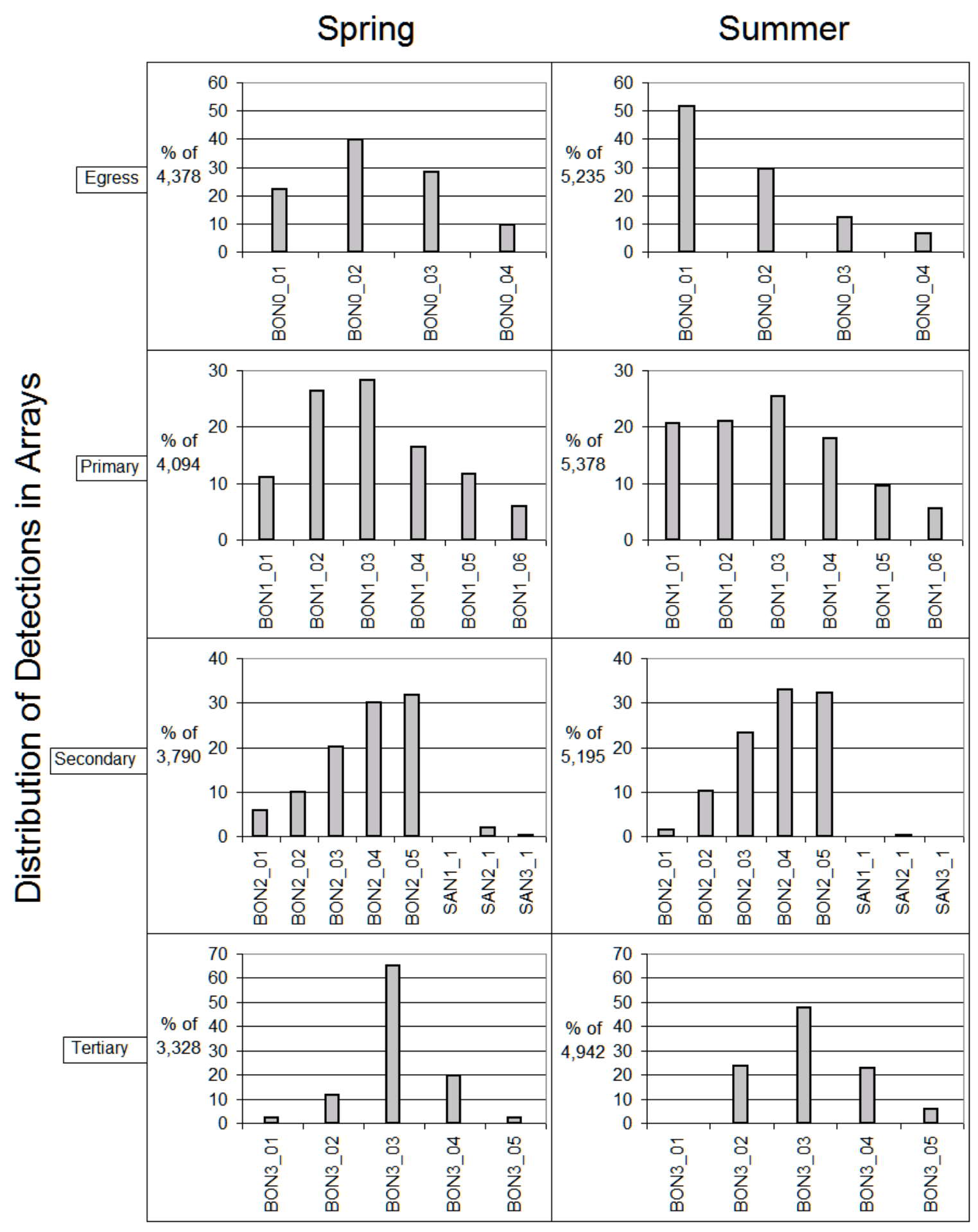

\section{Autonomous Node}

Figure 3.8. Percent of Acoustic Tag Detections on Autonomous Nodes Deployed in Arrays Downstream of Bonneville Dam in Spring and Summer. Primary, secondary, and tertiary arrays were used to estimate survival. In general, the Washington shore would be on the left side of each panel and the Oregon shore on the right, although all three Sandy River nodes were near the Oregon shore. (See Figures 2.10, 2.11, and 2.12 for exact locations of autonomous nodes.) 


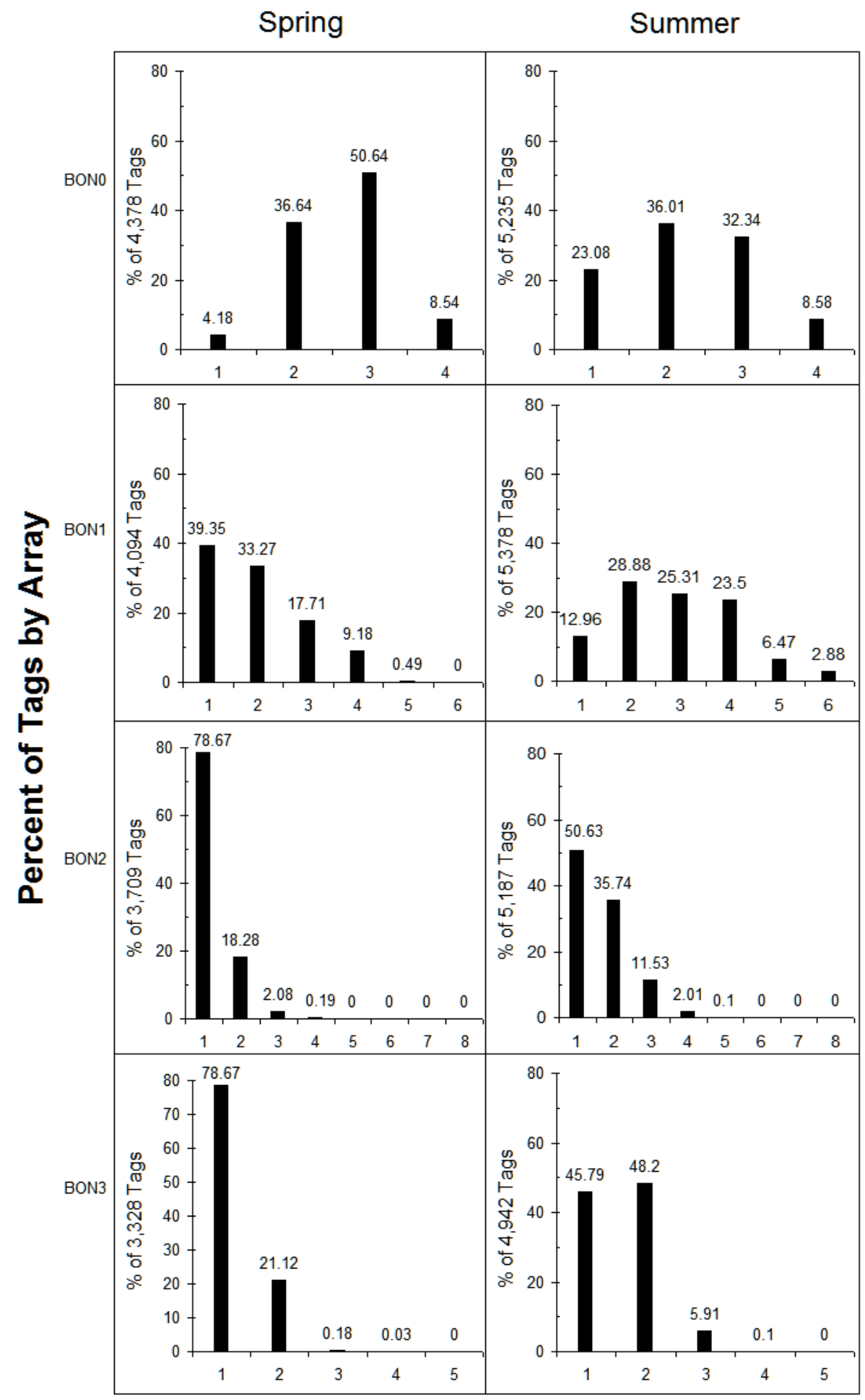

Number of Nodes Detecting Tags

Figure 3.9. Frequency of Detections on Multiple Autonomous Nodes Within the Egress Array (BON0) and Survival Arrays (BON1, BON2, and BON3) 
The probability of implanted acoustic tags being detected by survival arrays BON1and BON2 was very high throughout 2007 and varied through time largely because of changes in river discharge (Figure 3.10). For the BON1 array near Rooster Rock State Park, Oregon, the mean detection probability $\left(\mathrm{p}_{1}\right)$ was $92.7 \%$ (95\% CI: $\left.90.0 \leq \mathrm{p}_{1} \leq 94.4\right)$ in spring and 98.8\% (95\% CI: $\left.98.1 \leq \mathrm{p}_{1} \leq 98.8\right)$ in summer. For the BON2 array near Reed Island, mean detection probability $\left(\mathrm{p}_{2}\right)$ was $87.5 \%$

(95\% CI: $\left.85.7 \leq \mathrm{p}_{2} \leq 89.2\right)$ in spring and $96.6 \%$ (95\% CI: $95.5 \leq \mathrm{p}_{2} \leq 97.3$ ) in summer. Detectability of both arrays tended to decline in spring as river discharge increased and was usually was highest in summer when river discharge was low.

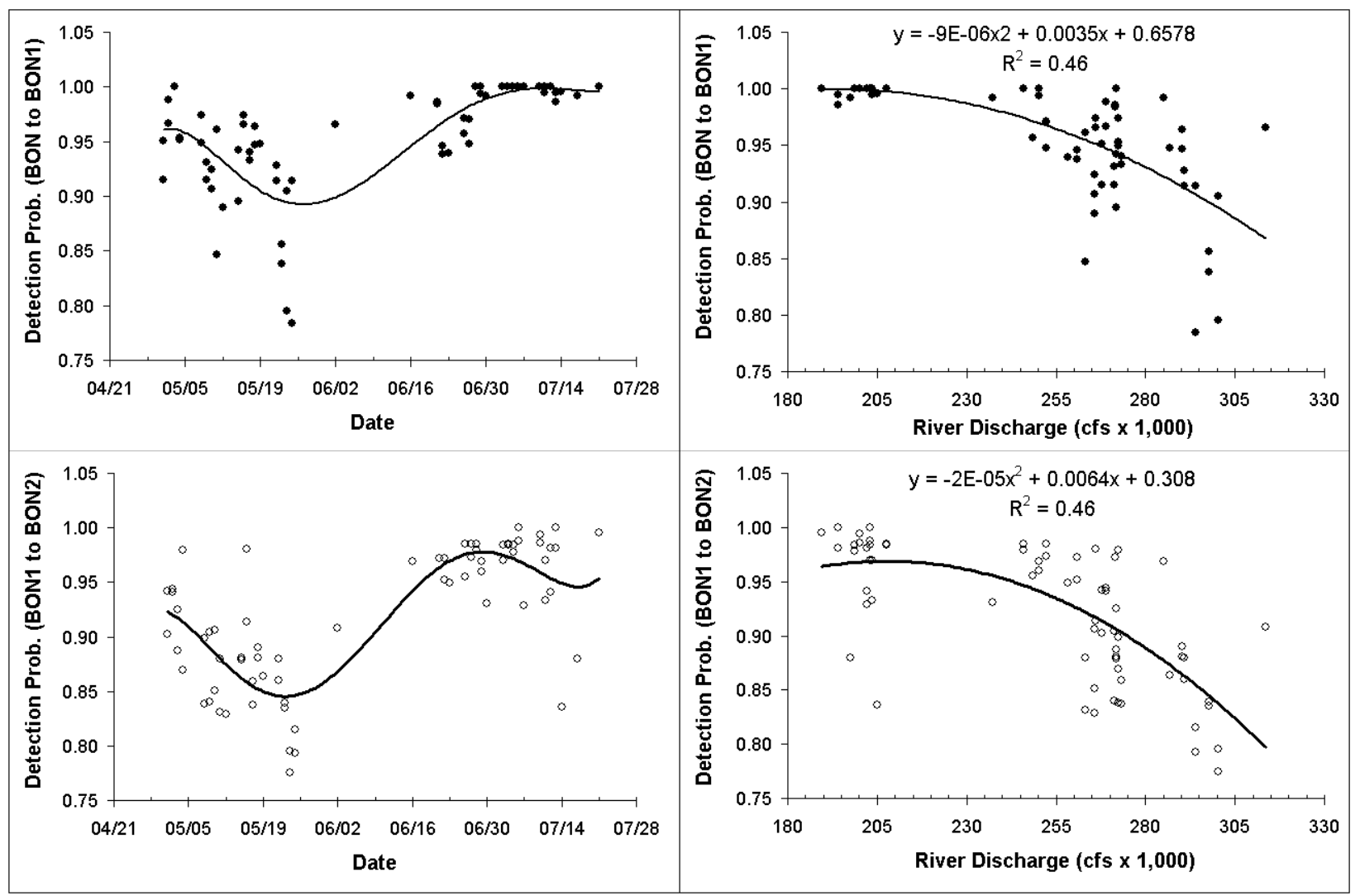

Figure 3.10. Detection Probabilities as a Function of Sampling Date (Left) and River Discharge (Right). Points in the upper plots are of means for individual releases in the forebay and tailrace on array BON1, and points in lower plots are means for individual forebay and tailrace releases on array BON2.

\subsection{Egress Rates}

Average travel time for fish to passing all downstream survival arrays (a distance of $42.4 \mathrm{~km}$ ) was less than 24 hours each season, and mean egress rates were similar in spring (Figure 3.11) and summer (Figure 3.12). In spring, yearlings released in the tailrace took an average of 1.3 hours to reach the egress array (BON0) located $7.5 \mathrm{~km}$ downstream from the tailrace release site. This rate was about 1.4 to 2.2 hours faster than the average time required for fish released in the spillway forebay (2.7 to 3.5 hours) to travel $9 \mathrm{~km}$ downstream. In summer, subyearling travel time from the tailrace release location to the egress array averaged 1.6 hours, and this was 1.4 to 2.4 hours faster than the average travel time for most fish released in the spillway forebay (3.0 to 4.0 hours). For subyearlings in summer, we found that the 
mean travel time from the time of spillway passage to the egress array located $9 \mathrm{~km}$ downstream of the dam was 20 minutes longer ( $\mathrm{P}=0.0105$ ) for fish passing middle bays with shallow flow deflectors (2.58 hours) than it was for fish passing end bays with deep deflectors (2.26 hours). On average, it took yearlings 8.2 to 11.0 hours (mean $=9.6$ hours) to reach the primary array (BON1), 11.3 to 14.0 hours (mean $=12.65$ hours) to reach the secondary array (BON2), and 15.7 to 19.1 hours to reach the tertiary array (BON3) (Figure 3.11). Subyearlings took an average of 9.1 to 11.4 hours to reach the primary array, 11.5 to 14 hours to reach the secondary array, and 15.2 to 17.6 hours to reach the tertiary array (Figure 3.12). Of the tagged fish released alive in the spillway forebay each season, only 2 yearlings $(0.1 \%)$ and 58 subyearlings (1.95\%) were detected passing B2 by PIT detection systems in the JBS and B2CC.

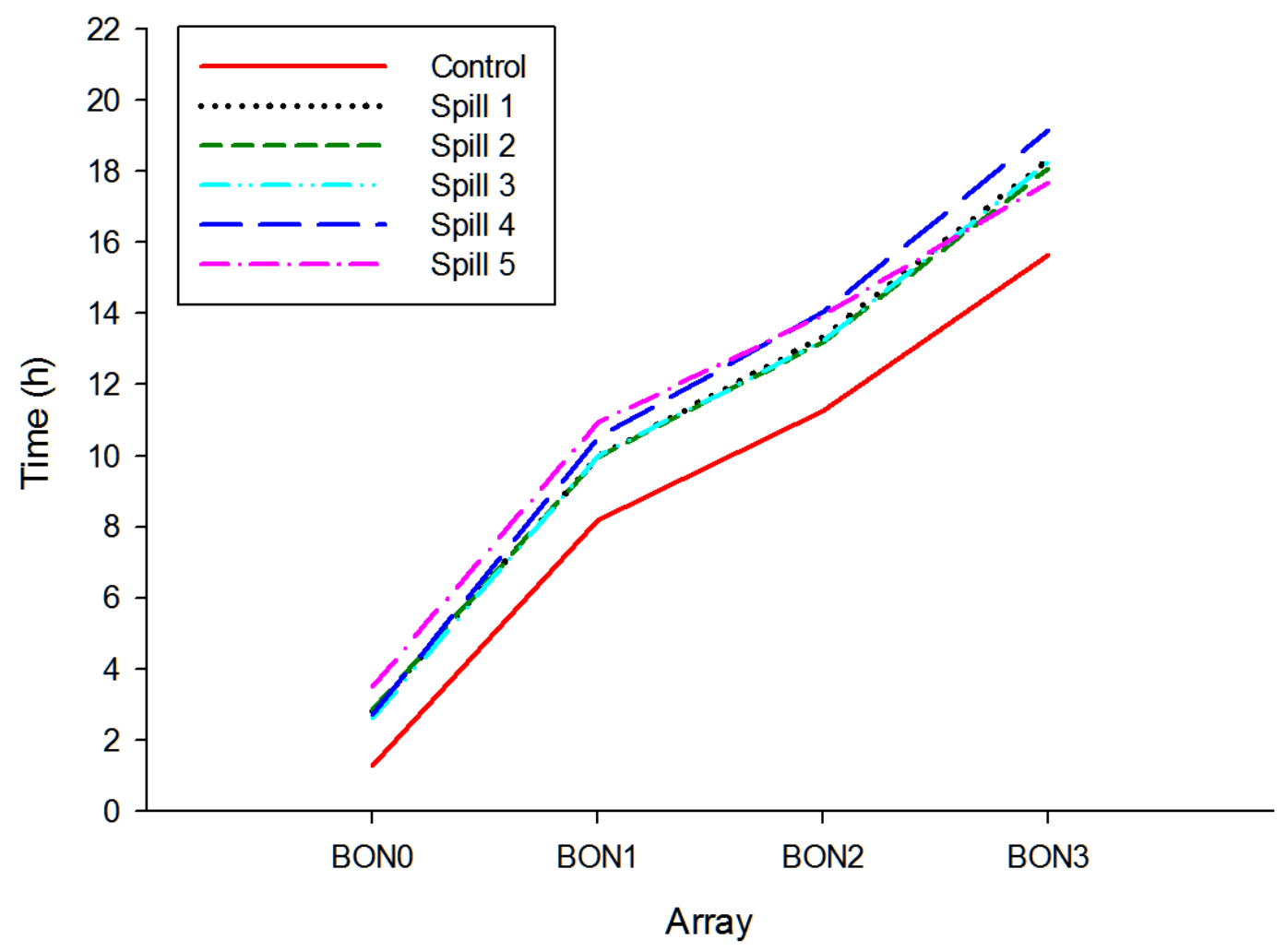

Figure 3.11. Plot of Average Travel Time for Tagged Yearling Chinook Salmon Released in the Spillway Forebay (Spill 1 Through 5) and the Tailrace (Control) to Four Arrays of Autonomous Nodes Downstream. Mean distance below the dam was $9 \mathrm{~km}$ for the egress array (BON0), $25 \mathrm{~km}$ for the primary array (BON1), $34.4 \mathrm{~km}$ for the secondary array (BON2), and $42.4 \mathrm{~km}$ for the tertiary array (BON3). 


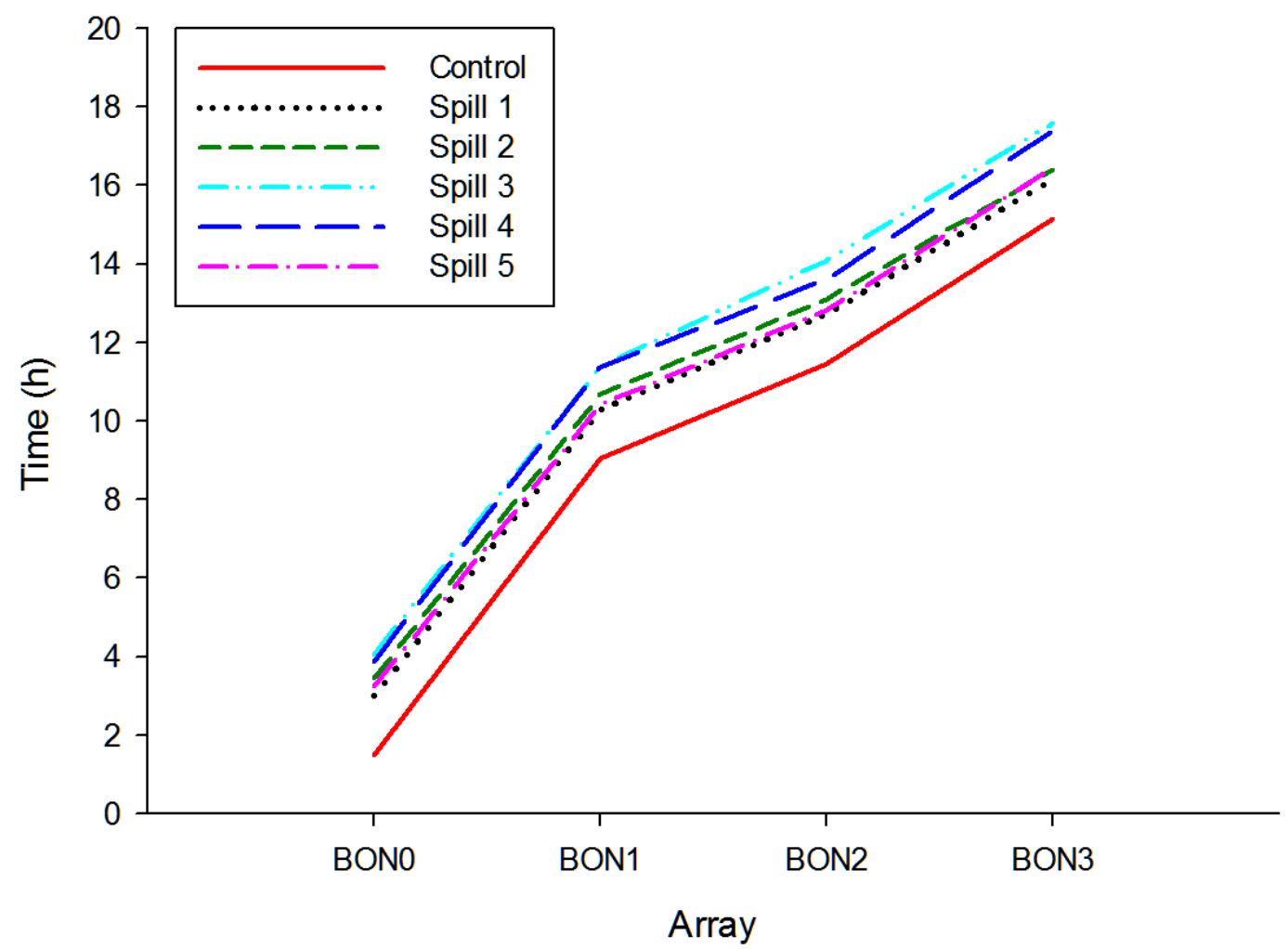

Figure 3.12. Plot of Average Travel Time for Tagged Subyearling Chinook Salmon Released in the Spillway Forebay (Spill 1 Through 5) and the Tailrace (Control) to Four Arrays of Autonomous Nodes Downstream. Mean distance below the dam was $9 \mathrm{~km}$ for the egress array (BON0), $25 \mathrm{~km}$ for the primary array (BON1), $34.4 \mathrm{~km}$ for the secondary array (BON2), and $42.4 \mathrm{~km}$ for the tertiary array (BON3).

\subsection{Detection and Survival of Yearling Chinook Salmon in Spring}

The tag-life study conducted in the spring, the survival of spill-way passed yearlings, and the comparison of spill bays using deep and shallow flow deflectors in the spring are described in the following sections.

\subsubsection{Tag-Life Study}

During the spring study, two different batches of SC acoustic tags were used; some were manufactured in 2006, others in 2007. Appreciably different mean tag lives were observed between manufacturing batches with an average tag life of 36.5 days ( $\widehat{\mathrm{SE}}=8.2)$ for the 2006 tags, and 53.1 days $(\widehat{\mathrm{SE}}=13.4)$ for the 2007 tags. Both tag groups reasonably followed a Weibull survivorship curve (Figure 3.13). Fish tagged with the 2006 manufacturing lot (i.e., releases on May 22 and 25, 2007) successfully traversed the study area before tag failures began (Figure 3.14). For these groups, no tag-life correction was necessary. For fish tagged with the 2007 tag lot, some minor tag-life correction was performed, even though the correction was in the third decimal place of the estimated survival probabilities. 
a. $2006 \mathrm{SC}$ Acoustic Tags

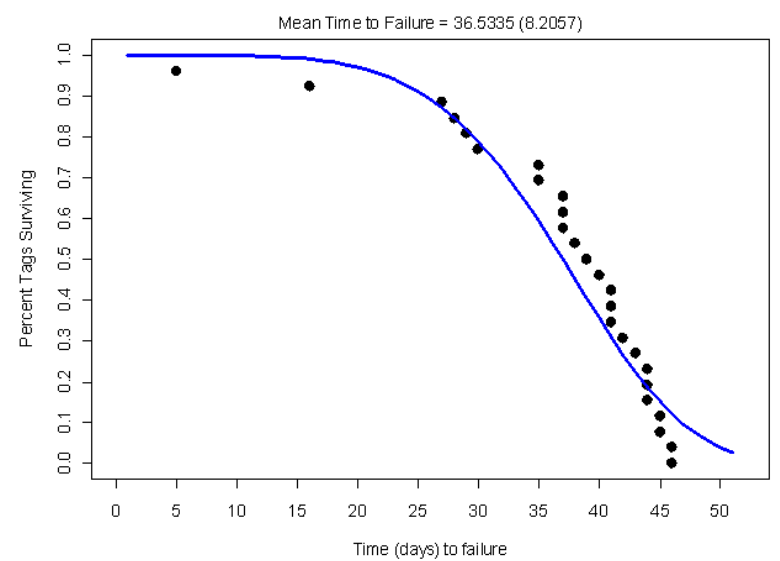

b. $2007 \mathrm{SC}$ Acoustic Tags

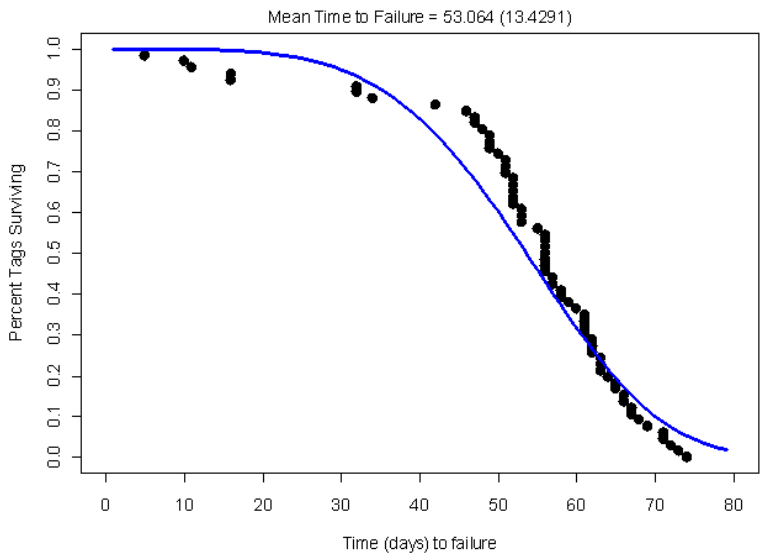

Figure 3.13. Estimated Acoustic Tag-Life Curves from the Tag-Life Study Run Concurrently with the Spring Chinook Survival Study at Bonneville Dam. Tags used were the (a) 2006 SC and (b) 2007 SC acoustic tags.

\subsubsection{Survival of Spillway-Passed Yearlings}

Yearling Chinook salmon released in the spillway forebay and not detected passing at non-spillway routes were identified and their downstream capture probabilities were recorded (Table 3.2, Table 3.3). Capture histories were differentiated between 2006 and 2007 tag lots. Similarly, capture histories were generated for tailrace releases differentiated by tag lot (Table 3.4, Table 3.5). Tag-life-corrected Cormack (1964), Jolly (1965), Seber (1965) (CJS) estimates of reach survival were calculated for each spillway release (Table 3.6; Table 3.7) and tailrace release (Table 3.8, Table 3.9). For each daily release pair, estimates of spillway passage survival were calculated using the fully parameterized CJS model (Table 3.11). Across the 16 paired-release trials, we estimated a weighted-average spillway survival of $\hat{s}_{\text {spin }}=$ 0.957 ( $\widehat{\mathrm{SE}}=0.013)$. A 95\% confidence interval would be $(0.931 \leq S \leq 0.983)$.

Table 3.2. Detection Histories for All Spillway-Passed Spring Chinook Salmon Tagged with the SC 2006 Acoustic Tags. Headings of columns 2 through 9 have three digits and each digit represents a detection (1) or non-detection (0) on each of three successive survival arrays (BON1, BON2, and BON3, respectively). A test for homogeneity was not significant ( $\mathrm{P}=$ 0.1517).

\begin{tabular}{cccccccccc}
\hline Virtual Release Date & 111 & 011 & 101 & 001 & 110 & 010 & 100 & 000 & Total \\
\hline 22 May 2007 & 37 & 3 & 6 & 0 & 14 & 0 & 1 & 5 & 66 \\
25 May 2007 & 21 & 2 & 8 & 0 & 3 & 0 & 3 & 5 & 42 \\
Pooled & 58 & 5 & 14 & 0 & 17 & 0 & 4 & 10 & 108 \\
\hline
\end{tabular}




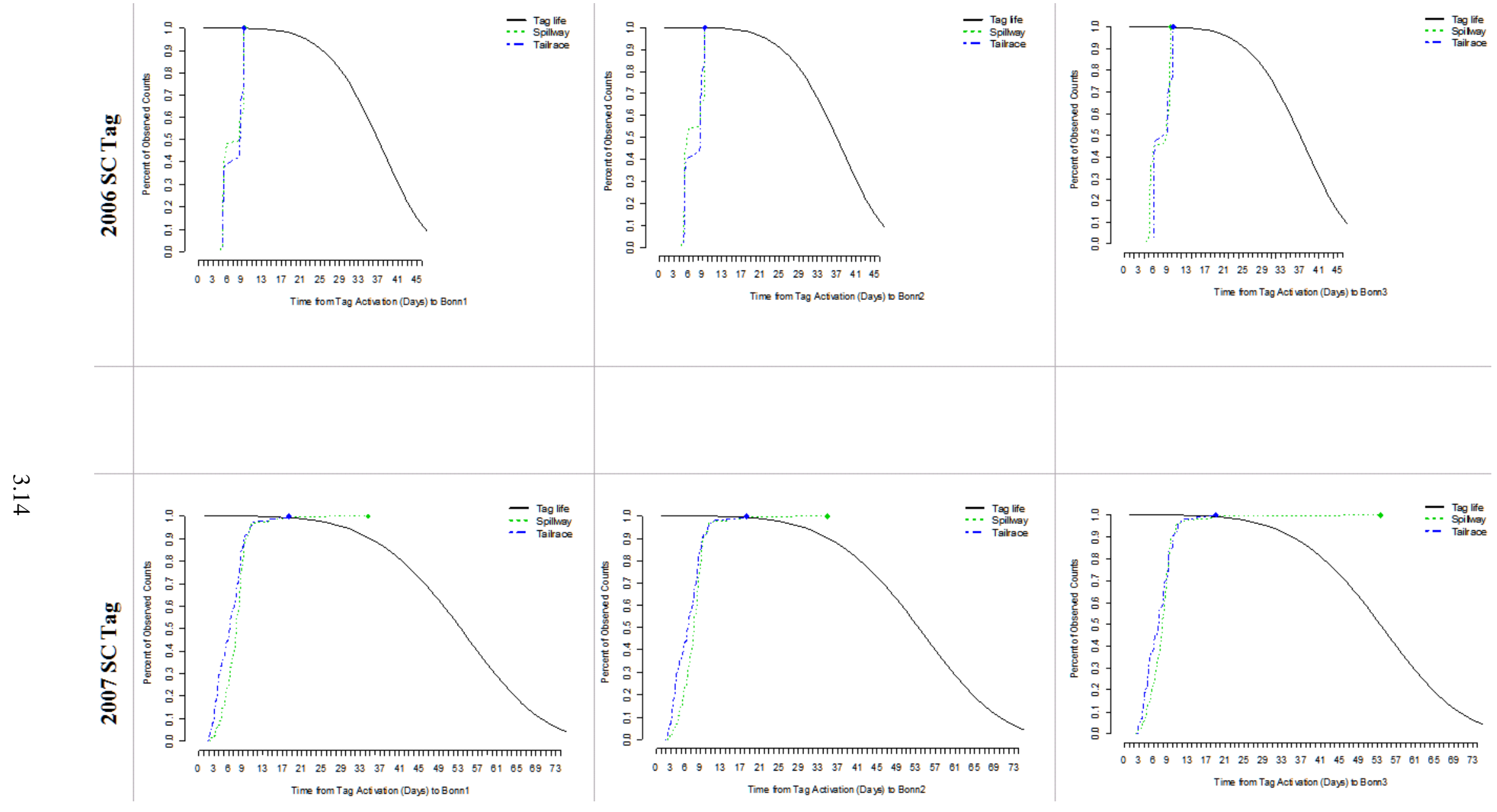

Figure 3.14. Comparison of the the Time of Activation of 2006 SC and 2007 SC Tags to the Time of Detection at Each of the Detection Arrays (BON1, BON2, and BON3) for Each Release Site (Spillway Forebay and Tailrace) 
Table 3.3. Detection Histories for All Spillway-Passed Spring Chinook Salmon Tagged with the SC 2007 Acoustic Tags. Headings of columns 2 through 9 have three digits and each digit represents a detection (1) or non-detection (0) on each of three successive survival arrays (BON1, BON2, and BON3, respectively). A test for homogeneity was very significant $(\mathrm{P}<0.0001)$.

\begin{tabular}{cccccccccc}
\hline Virtual Release Date & 111 & 011 & 101 & 001 & 110 & 010 & 100 & 000 & Total \\
\hline 1 May 2007 & 110 & 4 & 11 & 3 & 21 & 6 & 1 & 27 & 183 \\
2 May 2007 & 135 & 1 & 8 & 0 & 26 & 1 & 2 & 13 & 186 \\
3 May 2007 & 125 & 0 & 16 & 0 & 27 & 0 & 4 & 15 & 187 \\
4 May 2007 & 102 & 4 & 16 & 0 & 24 & 3 & 6 & 30 & 185 \\
8 May 2007 & 91 & 2 & 17 & 1 & 40 & 1 & 10 & 23 & 185 \\
9 May 2007 & 100 & 3 & 11 & 0 & 37 & 8 & 8 & 20 & 187 \\
10 May 2007 & 109 & 7 & 10 & 2 & 26 & 3 & 6 & 23 & 186 \\
11 May 2007 & 100 & 3 & 19 & 2 & 28 & 1 & 11 & 23 & 187 \\
15 May 2007 & 118 & 6 & 16 & 1 & 28 & 3 & 9 & 8 & 189 \\
16 May 2007 & 114 & 3 & 11 & 0 & 26 & 1 & 11 & 17 & 183 \\
17 May 2007 & 112 & 4 & 16 & 3 & 29 & 3 & 5 & 13 & 185 \\
18 May 2007 & 111 & 2 & 14 & 0 & 35 & 4 & 9 & 11 & 186 \\
22 May 2007 & 73 & 7 & 13 & 0 & 17 & 1 & 9 & 2 & 122 \\
23 May 2007 & 85 & 11 & 12 & 7 & 32 & 7 & 12 & 22 & 188 \\
24 May 2007 & 87 & 6 & 25 & 2 & 31 & 7 & 12 & 18 & 188 \\
25 May 2007 & 69 & 6 & 15 & 2 & 22 & 2 & 9 & 10 & 135 \\
Pooled & 1641 & 69 & 230 & 23 & 449 & 51 & 124 & 275 & 2862 \\
\hline
\end{tabular}

Table 3.4. Detection Histories for All Tailrace-Released Spring Chinook Salmon Tagged with the SC 2006 Acoustic Tags. Headings of columns 2 through 9 have three digits and each digit represents a detection (1) or non-detection (0) on each of three successive survival arrays (BON1, BON2, and BON3, respectively). A test for homogeneity was not significant $(\mathrm{P}=0.9026)$.

\begin{tabular}{cccccccccc}
\hline Virtual Release Date & 111 & 011 & 101 & 001 & 110 & 010 & 100 & 000 & Total \\
\hline 22 May 2007 & 11 & 1 & 5 & 0 & 4 & 1 & 1 & 2 & 25 \\
25 May 2007 & 8 & 1 & 3 & 0 & 6 & 0 & 1 & 1 & 20 \\
Pooled & 19 & 2 & 8 & 0 & 10 & 1 & 2 & 3 & 45 \\
\hline
\end{tabular}


Table 3.5. Detection Histories for All Tailrace-Released Spring Chinook Salmon Tagged with the SC 2007 Acoustic Tags. Headings of columns 2 through 9 have three digits and each digit represents a detection (1) or non-detection (0) on each of three successive survival arrays (BON1, BON2, and BON3, respectively). A test for homogeneity was very significant $(P<0.0001)$.

\begin{tabular}{lccccccccc}
\hline Virtual Release Date & 111 & 011 & 101 & 001 & 110 & 010 & 100 & 000 & Total \\
\hline 1 May 2007 & 48 & 1 & 3 & 0 & 7 & 2 & 2 & 2 & 65 \\
2 May 2007 & 47 & 1 & 3 & 0 & 9 & 1 & 1 & 3 & 65 \\
3 May 2007 & 49 & 0 & 4 & 0 & 5 & 0 & 1 & 5 & 64 \\
4 May 2007 & 45 & 1 & 1 & 0 & 13 & 2 & 2 & 1 & 65 \\
8 May 2007 & 40 & 0 & 5 & 0 & 11 & 3 & 1 & 4 & 64 \\
9 May 2007 & 39 & 3 & 7 & 1 & 8 & 1 & 2 & 4 & 65 \\
10 May 2007 & 40 & 0 & 4 & 3 & 5 & 2 & 3 & 7 & 64 \\
11 May 2007 & 39 & 5 & 5 & 1 & 6 & 3 & 3 & 2 & 64 \\
12 May 2007 & 149 & 12 & 27 & 9 & 37 & 5 & 5 & 6 & 250 \\
15 May 2007 & 33 & 4 & 5 & 0 & 13 & 2 & 4 & 4 & 65 \\
16 May 2007 & 47 & 1 & 1 & 0 & 9 & 1 & 1 & 3 & 63 \\
17 May 2007 & 38 & 3 & 7 & 1 & 11 & 0 & 3 & 2 & 65 \\
18 May 2007 & 34 & 3 & 5 & 0 & 15 & 0 & 5 & 3 & 65 \\
19 May 2007 & 143 & 9 & 22 & 2 & 52 & 1 & 11 & 10 & 250 \\
22 May 2007 & 20 & 2 & 3 & 0 & 9 & 1 & 2 & 3 & 40 \\
23 May 2007 & 26 & 7 & 7 & 0 & 15 & 1 & 2 & 7 & 65 \\
24 May 2007 & 29 & 7 & 6 & 4 & 12 & 1 & 2 & 4 & 65 \\
25 May 2007 & 19 & 4 & 3 & 3 & 7 & 1 & 4 & 4 & 45 \\
2 June 2007 & 177 & 1 & 17 & 1 & 31 & 6 & 9 & 8 & 250 \\
Pooled & 1062 & 64 & 135 & 25 & 275 & 33 & 63 & 82 & 1739 \\
\hline
\end{tabular}

Table 3.6. Cormack-Jolly-Seber Survival and Detection Probabilities (Single-Release Estimates) for Spillway-Forebay-Released Yearling Chinook Salmon Bearing SC 2006 Tags and Traveling from Just Below Bonneville Dam (BON) to Array BON1 and from Arrays BON1 to BON2 by Virtual Release Date. The last column shows the product of survival and detection probabilities $(\lambda)$ for the tertiary array. Numbers in parentheses are standard errors on probabilities.

\begin{tabular}{cccccc}
\hline & \multicolumn{2}{c}{ Survival } & \multicolumn{2}{c}{ Detection } & $\begin{array}{c}\text { Combination of } \\
\text { Sirtual Release } \\
\text { Date }\end{array}$ \\
\cline { 2 - 6 } & BON to BON1 & BON1 to BON2 & BON1 & BON2 & $\begin{array}{c}\text { Detection at } \\
\text { BON3 }\end{array}$ \\
\hline 22 May 2007 & $0.926(0.033)$ & $1.000(<0.001)$ & $0.949(0.028)$ & $0.884(0.041)$ & $0.753(0.055)$ \\
25 May 2007 & $0.886(0.051)$ & $0.942(0.052)$ & $0.941(0.040)$ & $0.742(0.079)$ & $0.885(0.063)$ \\
Pooled & $0.909(0.028)$ & $0.995(0.026)$ & & & \\
\hline
\end{tabular}


Table 3.7. Cormack-Jolly-Seber Survival and Detection Probabilities (Single-Release Estimates), Adjusted for Estimated Tag Life, for Spillway-Forebay-Released Yearling Chinook Salmon Bearing SC 2007 Tags and Traveling from Bonneville Dam (BON) to Array BON1 and from Arrays BON1 to BON2 by Virtual Release Date. The last column shows the product of survival and detection probabilities $(\lambda)$ for the tertiary array. Numbers in parentheses are standard errors on probabilities.

\begin{tabular}{rccccc}
\hline \multirow{2}{*}{$\begin{array}{c}\text { Virtual Release } \\
\text { Date }\end{array}$} & \multicolumn{2}{c}{ Survival } & \multicolumn{2}{c}{ Detection } & $\begin{array}{c}\text { Combination of } \\
\text { Survival to and } \\
\text { Detection at BON3 }\end{array}$ \\
\cline { 2 - 6 } & BON to BON1 & BON1 to BON2 & BON1 & BON2 & $0.819(0.031)$ \\
\hline 1 May 2007 & $0.854(0.026)$ & $1.000(<0.001)$ & $0.915(0.022)$ & $0.902(0.024)$ & $0.834(0.029)$ \\
2 May 2007 & $0.930(0.019)$ & $0.997(0.009)$ & $0.988(0.008)$ & $0.944(0.019)$ & $0.822(0.031)$ \\
3 May 2007 & $0.920(0.020)$ & $0.997(0.013)$ & $1.000(<0.001)$ & $0.887(0.027)$ & $0.797(0.035)$ \\
4 May 2007 & $0.840(0.027)$ & $0.986(0.019)$ & $0.953(0.017)$ & $0.869(0.031)$ & $0.694(0.040)$ \\
8 May 2007 & $0.878(0.024)$ & $0.986(0.025)$ & $0.974(0.013)$ & $0.838(0.035)$ & $0.696(0.038)$ \\
9 May 2007 & $0.896(0.023)$ & $0.977(0.021)$ & $0.931(0.020)$ & $0.904(0.028)$ & $0.800(0.033)$ \\
10 May 2007 & $0.879(0.024)$ & $0.979(0.017)$ & $0.924(0.021)$ & $0.906(0.026)$ & $0.780(0.036)$ \\
11 May 2007 & $0.879(0.024)$ & $0.966(0.024)$ & $0.961(0.016)$ & $0.831(0.034)$ & $0.800(0.032)$ \\
15 May 2007 & $0.961(0.015)$ & $0.971(0.019)$ & $0.942(0.018)$ & $0.879(0.027)$ & $0.813(0.033)$ \\
16 May 2007 & $0.909(0.022)$ & $0.947(0.021)$ & $0.974(0.013)$ & $0.914(0.025)$ & $0.784(0.036)$ \\
17 May 2007 & $0.932(0.019)$ & $1.000(0.027)$ & $0.940(0.018)$ & $0.859(0.033)$ & $0.743(0.035)$ \\
18 May 2007 & $0.943(0.017)$ & $0.974(0.020)$ & $0.964(0.014)$ & $0.890(0.028)$ & $0.816(0.039)$ \\
22 May 2007 & $0.989(0.012)$ & $0.944(0.028)$ & $0.928(0.025)$ & $0.860(0.036)$ & $0.711(0.039)$ \\
23 May 2007 & $0.895(0.024)$ & $0.961(0.028)$ & $0.838(0.030)$ & $0.835(0.035)$ & $0.710(0.040)$ \\
24 May 2007 & $0.911(0.022)$ & $0.987(0.028)$ & $0.905(0.023)$ & $0.775(0.038)$ & $0.758(0.043)$ \\
25 May 2007 & $0.933(0.023)$ & $0.965(0.030)$ & $0.914(0.260)$ & $0.815(0.040)$ & \\
Weighted Avg. & $0.930(0.011)$ & $0.999(0.001)$ & & & \\
\hline
\end{tabular}

Table 3.8. Cormack-Jolly-Seber Survival and Detection Probabilities (Single-Release Estimates) for Tailrace-Released Yearling Chinook Salmon Bearing SC 2006 Tags and Traveling from Just Below Bonneville Dam (BON) to Array BON1 and from Arrays BON1 to BON2 by Virtual Release Date. The last column shows the product of survival and detection probabilities $(\lambda)$ for the tertiary array. Numbers in parentheses are standard errors on probabilities.

\begin{tabular}{|c|c|c|c|c|c|}
\hline \multirow[b]{2}{*}{ Virtual Release Date } & \multicolumn{2}{|c|}{ Survival } & \multicolumn{2}{|c|}{ Detection } & \multirow{2}{*}{$\begin{array}{c}\text { Combination of } \\
\text { Survival to and } \\
\text { Detection at BON3 }\end{array}$} \\
\hline & BON to BON1 & BON1 to BON2 & BON1 & BON2 & \\
\hline 22 May 2007 & $0.924(0.055)$ & $1.000(0.017)$ & $0.907(0.062)$ & $0.734(0.093)$ & $0.734(0.093)$ \\
\hline 25 May 2007 & $0.953(0.049)$ & $1.000(<0.001)$ & $0.943(0.055)$ & $0.786(0.095)$ & $0.629(0.111)$ \\
\hline Pooled & 0.937 (0.037) & $1.000(<0.001)$ & & & \\
\hline
\end{tabular}


Table 3.9. Cormack-Jolly-Seber Survival and Detection Probabilities (Single-Release Estimates), Adjusted for Estimated Tag Life, for Tailrace-Released Yearling Chinook Salmon Bearing SC 2007 Tags and Traveling from Just Below Bonneville Dam (BON) to Array BON1 and from Arrays BON1 to BON2 by Virtual Release Date. The last column shows the product of survival and detection probabilities $(\lambda)$ for the tertiary array. Numbers in parentheses are standard errors on probabilities.

\begin{tabular}{cccccc}
\hline \multirow{2}{*}{$\begin{array}{c}\text { Virtual Release } \\
\text { Date }\end{array}$} & \multicolumn{2}{c}{ Survival } & Detection & $\begin{array}{c}\text { Combination of } \\
\text { Survival to and } \\
\text { Detection at BON3 }\end{array}$ \\
\cline { 2 - 5 } 1 May 2007 & BON to BON1 & BON1 to BON2 & BON1 & BON2 & $0.845(0.048)$ \\
\cline { 2 - 5 } 2 May 2007 & $0.971(0.021)$ & $0.975(0.024)$ & $0.951(0.028)$ & $0.942(0.032)$ & $0.828(0.050)$ \\
3 May 2007 & $0.922(0.034)$ & $0.990(0.018)$ & $1.000(<0.001)$ & $0.925(0.036)$ & $0.907(0.039)$ \\
4 May 2007 & $0.986(0.015)$ & $0.972(0.024)$ & $0.952(0.027)$ & $0.979(0.021)$ & $0.754(0.055)$ \\
8 May 2007 & $0.939(0.030)$ & $1.000(0.010)$ & $0.949(0.029)$ & $0.899(0.039)$ & $0.749(0.056)$ \\
9 May 2007 & $0.941(0.030)$ & $0.992(0.029)$ & $0.915(0.036)$ & $0.840(0.052)$ & $0.824(0.053)$ \\
10 May 2007 & $0.895(0.039)$ & $0.964(0.035)$ & $0.907(0.039)$ & $0.851(0.052)$ & $0.851(0.052)$ \\
11 May 2007 & $0.977(0.023)$ & $0.963(0.034)$ & $0.847(0.047)$ & $0.880(0.046)$ & $0.830(0.052)$ \\
12 May 2007 & $0.980(0.010)$ & $1.000(<0.001)$ & $0.890(0.020)$ & $0.829(0.024)$ & $0.804(0.026)$ \\
15 May 2007 & $0.946(0.030)$ & $0.960(0.040)$ & $0.895(0.041)$ & $0.881(0.050)$ & $0.712(0.063)$ \\
16 May 2007 & $0.953(0.027)$ & $0.986(0.018$ & $0.966(0.024)$ & $0.980(0.020)$ & $0.828(0.050)$ \\
17 May 2007 & $0.973(0.022)$ & $0.983(0.034)$ & $0.933(0.032)$ & $0.837(0.053)$ & $0.788(0.057)$ \\
18 May 2007 & $0.958(0.026)$ & $0.948(0.041)$ & $0.947(0.030)$ & $0.881(0.050)$ & $0.712(0.063)$ \\
19 May 2007 & $0.962(0.012)$ & $0.987(0.017)$ & $0.948(0.015)$ & $0.864(0.026)$ & $0.741(0.031)$ \\
22 May 2007 & $0.930(0.042)$ & $0.978(0.049)$ & $0.914(0.047)$ & $0.880(0.065)$ & $0.687(0.082)$ \\
23 May 2007 & $0.899(0.039)$ & $1.000(0.013)$ & $0.856(0.047)$ & $0.839(0.049)$ & $0.685(0.061)$ \\
24 May 2007 & $0.949(0.031)$ & $1.000(0.013)$ & $0.795(0.053)$ & $0.795(0.053)$ & $0.746(0.057)$ \\
25 May 2007 & $0.937(0.046)$ & $0.928(0.066)$ & $0.784(0.068)$ & $0.793(0.075)$ & $0.742(0.079)$ \\
2 June 2007 & $0.969(0.011)$ & $0.977(0.014)$ & $0.966(0.012)$ & $0.908(0.021)$ & $0.828(0.026)$ \\
Weighted Ave. & $0.966(0.004)$ & $1.000(0.001)$ & & & \\
\hline
\end{tabular}

Table 3.10. Estimated Paired-Release Survival and Standard Errors for Spillway-Passed Yearling Chinook Salmon Bearing SC 2006 Acoustic Tags

\begin{tabular}{cc}
\hline Virtual Release Date & $\hat{S}(\widehat{\mathrm{SE}})$ \\
\hline 22 May 2007 & $1.000(0.043)$ \\
25 May 2007 & $0.930(0.076)$ \\
Pooled & $0.970(0.059)$ \\
\hline
\end{tabular}


Table 3.11. Estimated Paired-Release Survival and Standard Errors, Adjusted for Estimated Tag Life, for Spillway-Passed Yearling Chinook Salmon Bearing SC 2007 Acoustic Tags. Numbers in parentheses are standard errors on survival.

\begin{tabular}{cc}
\hline Virtual Release Date & $\hat{S}(\widehat{\mathrm{SE}})$ \\
\hline 1 May 2007 & $0.879(0.033)$ \\
2 May 2007 & $0.975(0.033)$ \\
3 May 2007 & $0.998(0.043)$ \\
4 May 2007 & $0.852(0.030)$ \\
8 May 2007 & $0.935(0.039)$ \\
9 May 2007 & $0.952(0.039)$ \\
10 May 2007 & $0.982(0.051)$ \\
11 May 2007 & $0.900(0.032)$ \\
15 May 2007 & $1.016(0.036)$ \\
16 May 2007 & $0.954(0.035)$ \\
17 May 2007 & $0.958(0.029)$ \\
18 May 2007 & $0.984(0.032)$ \\
22 May 2007 & $1.063(0.050)$ \\
23 May 2007 & $0.996(0.051)$ \\
24 May 2007 & $0.960(0.039)$ \\
25 May 2007 & $0.996(0.055)$ \\
Weighted Ave. & $0.957(0.013)$ \\
\hline
\end{tabular}

\subsubsection{Comparison of Deep Versus Shallow Flow Deflector Bays in Spring}

During six spring trials, 165 spring Chinook salmon smolts were identified going through the shallow flow deflector bays (i.e., bays 4 through 15) (Table 3.12) and 114 through the deep flow deflector bays (i.e., bays 1 through 3 and 16 through 18) (Table 3.13). Chi-square tests of homogeneity found the survival and detection processes for the replicate trials not to be significantly different over the season $(\mathrm{P}<0.10)$. By necessity and lack of statistical power, releases 1 through 4 (i.e., May 16 through 23, 2007) were pooled because of extremely small sample sizes. However, the three groups for May 16 through 23, May24, and May 25 were treated distinctly in the analysis to provide an estimate of betweenreplicate variability. Using the single release-recapture model, reach survival estimates were calculated for each of the shallow (Table 3.14) and deep flow (Table 3.15) deflector virtual releases. For the shallow flow deflector releases, average weighted survival from Bonneville Dam to BON1 was 0.999 ( = 0.013) while it was 0.970 ( $=0.017$ ) for fish passing bays with deep flow deflectors.

Combining results of paired releases (Table 3.16), relative survival of deep-to-shallow deflector bay passage fish had a weighted average across replicate trials of $0.969(=0.028)$. An associated $95 \%$ confidence interval would be CI $0.849 \leq \mathrm{RS} 1 \leq 1.089=0.95$, which is very wide because of only two degrees of freedom. Survival through the deep flow deflector bays was not significantly greater 
(t2 $=-1.090, \mathrm{P}=0.805$ ) than passage survival through the shallow flow deflector bays. Figure 3.15 plots the relative survival for spring Chinook salmon by replicate trial. To assess the robustness of these results, the data also were pooled over the study. The relative survival of fish passing the deep versus shallow flow deflector was estimated to be RS $=0.982$ ( $=0.026)$, also indicating no significant improvement in survival through the deep flow deflector bays $(\mathrm{P}=0.752)$.

Relative survivals in the second reach between BON1 and BON2 were not significantly different from a value of 1 ( $\mathrm{t} 2=0.974, \mathrm{P}=0.216)$, indicating no difference in Reach 2 survival for fish passing deep and shallow flow deflectors (Table 3.16).

Table 3.12. Shallow Flow Deflector (i.e., bays 4 through 15 with deflectors at elevation $4.267 \mathrm{~m}$ above MSL) Spring Chinook Salmon Detection Histories at BON1, BON2, and BON3. Headings of columns 2 through 9 have three digits and each digit represents a detection (1) or non-detection (0) on each of three successive survival arrays (BON1, BON2, and BON3, respectively). A test for homogeneity across all release groups was not significant $(\mathrm{P}=0.797)$.

\begin{tabular}{cccccccccc}
\hline Virtual Release Date & 111 & 011 & 101 & 001 & 110 & 010 & 100 & 000 & Total \\
\hline 16 May 2007 & 13 & 0 & 0 & 0 & 1 & 0 & 0 & 0 & 14 \\
17 May 2007 & 7 & 0 & 0 & 0 & 1 & 0 & 0 & 0 & 8 \\
22 May 2007 & 19 & 2 & 3 & 0 & 6 & 0 & 2 & 0 & 32 \\
23 May 2007 & 28 & 1 & 3 & 1 & 12 & 1 & 2 & 5 & 53 \\
24 May 2007 & 11 & 1 & 2 & 0 & 6 & 0 & 3 & 0 & 23 \\
25 May 2007 & 21 & 1 & 4 & 1 & 5 & 0 & 2 & 1 & 35 \\
Pooled & 99 & 5 & 12 & 2 & 31 & 1 & 9 & 6 & 165 \\
\hline
\end{tabular}

Table 3.13. Deep Flow Deflector (i.e., bays 1 through 3 and 16 through 18 with deflectors at $2.134 \mathrm{~m}$ above MSL) Spring Chinook Salmon Detection Histories at BON1, BON2, and BON3. Headings of columns 2 through 9 have three digits and each digit represents a detection (1) or non-detection (0) on each of three successive survival arrays (BON1, BON2, and BON3, respectively). A test for homogeneity across all release groups was not significant $(\mathrm{P}=0.103)$.

\begin{tabular}{crrrrrrrrr}
\hline Virtual Release Date & 111 & 011 & 101 & 001 & 110 & 010 & 100 & 000 & Total \\
\hline 01 May 2007 & 1 & 0 & 0 & 0 & 0 & 0 & 0 & 0 & 1 \\
16 May 2007 & 5 & 0 & 0 & 0 & 0 & 0 & 0 & 2 & 7 \\
17 May 2007 & 5 & 0 & 0 & 0 & 0 & 0 & 0 & 0 & 5 \\
23 May 2007 & 0 & 0 & 0 & 0 & 0 & 0 & 1 & 0 & 1 \\
24 May 2007 & 26 & 1 & 6 & 0 & 9 & 1 & 2 & 3 & 48 \\
25 May 2007 & 29 & 2 & 8 & 1 & 9 & 1 & 1 & 1 & 52 \\
Pooled & 66 & 3 & 14 & 1 & 18 & 2 & 4 & 6 & 114 \\
\hline
\end{tabular}


Table 3.14. Single-Release Survival and Detection Estimates for Yearling Chinook Salmon Passing Bays with Shallow Flow Deflectors and Traveling from Bonneville Dam (BON) to Array BON1 and from Array BON1 to BON2 by Virtual Release Date. The last column shows the product of survival and detection probabilities $(\lambda)$ for the tertiary array. Numbers in parentheses are standard errors on probabilities.

\begin{tabular}{|c|c|c|c|c|c|}
\hline \multirow{2}{*}{$\begin{array}{c}\text { Virtual Release } \\
\text { Date }\end{array}$} & \multicolumn{2}{|c|}{ Survival } & \multicolumn{2}{|c|}{ Detection } & \multirow{2}{*}{$\begin{array}{l}\text { Combination of } \\
\text { Survival to and } \\
\text { Detection at } \\
\text { BON3 }\end{array}$} \\
\hline & $\mathrm{BON}$ to BON1 & BON1 to BON2 & BON1 & BON2 & \\
\hline 16-23 May 2007 & $0.955(0.020)$ & $0.979(0.023)$ & $0.949(0.022)$ & $0.909(0.033)$ & $0.769(0.044)$ \\
\hline 24 May 2007 & 1.007 (0.008) & $0.907(0.085)$ & $0.950(0.049)$ & $0.857(0.094)$ & $0.667(0.111)$ \\
\hline 25 May 2007 & $0.975(0.029)$ & $0.971(0.049)$ & $0.938(0.043)$ & $0.815(0.075)$ & $0.815(0.075)$ \\
\hline Weighted Avg. & 0.999 (0.029) & $0.974(0.011)$ & & & \\
\hline
\end{tabular}

Table 3.15. Single-Release Survival and Detection Estimates for Yearling Chinook Salmon Passing Bays with Deep Flow Deflectors and Traveling from Bonneville Dam (BON) to Array BON1 and from Array BON1 to BON2 by Virtual Release Date. The last column shows the product of survival and detection probabilities $(\lambda)$ for the tertiary array. Numbers in parentheses are standard errors on probabilities.

\begin{tabular}{cccccc}
\hline & \multicolumn{2}{c}{ Survival } & \multicolumn{2}{c}{ Detection } & $\begin{array}{c}\text { Combination of } \\
\text { Survival to and } \\
\text { Virtual Release } \\
\text { Date }\end{array}$ \\
\cline { 2 - 6 } & BON to BON1 & BON1 to BON2 & BON1 & BON2 & BON3 \\
\hline 16-23 May 2007 & $0.857(0.094)$ & $0.917(0.080)$ & $1.000(<0.001)$ & $1.000(<0.001)$ & $1.000(<0.001)$ \\
24 May 2007 & $0.940(0.035)$ & $1.003(0.043)$ & $0.953(0.032)$ & $0.818(0.067)$ & $0.730(0.073)$ \\
25 May 2007 & $0.982(0.019)$ & $1.036(0.035)$ & $0.920(0.038)$ & $0.775(0.066)$ & $0.756(0.067)$ \\
Weighted Avg. & $0.970(0.017)$ & $1.014(0.024)$ & & & \\
\hline
\end{tabular}

Table 3.16. Estimated Relative Survival (deep and shallow from Tables 3.15 and 3.14, respectively) by Release Pair. Numbers in parentheses are standard errors on survival.

\begin{tabular}{ccc}
\hline & \multicolumn{2}{c}{ Relative Survival } \\
\cline { 2 - 3 } Virtual Release Date & BON to BON1 & BON1 to BON2 \\
\hline 23 May 2007 & $0.897(0.100)$ & $0.937(0.085)$ \\
24 May 2007 & $0.934(0.036)$ & $1.106(0.114)$ \\
25 May 2007 & $1.007(0.036)$ & $1.067(0.065)$ \\
Weighted Avg. & $0.969(0.028)$ & $1.042(0.044)$ \\
\hline
\end{tabular}




\subsection{Detection and Survival of Subyearling Chinook Salmon in Summer}

The tag-life study conducted during the summer and the comparison of survivals for subyearling Chinook salmon passing through spill bays containing the deep and shallow flow deflectors during the summer are described in the following sections.

\subsubsection{Tag-Life Study}

In summer, the mean time until failure of ATS acoustic tags was about 86.4 days and the data were well fit by a Weibull survivorship curve (Figure 3.16). Smolts passed through the survival arrays before corrections in tag life were necessary (Figure 3.17; Figure 3.18; Figure 3.19). Therefore, unadjusted CJS estimates of survival could be directly calculated and did not require a tag-life correction.

Relative Survival, Release to BON1

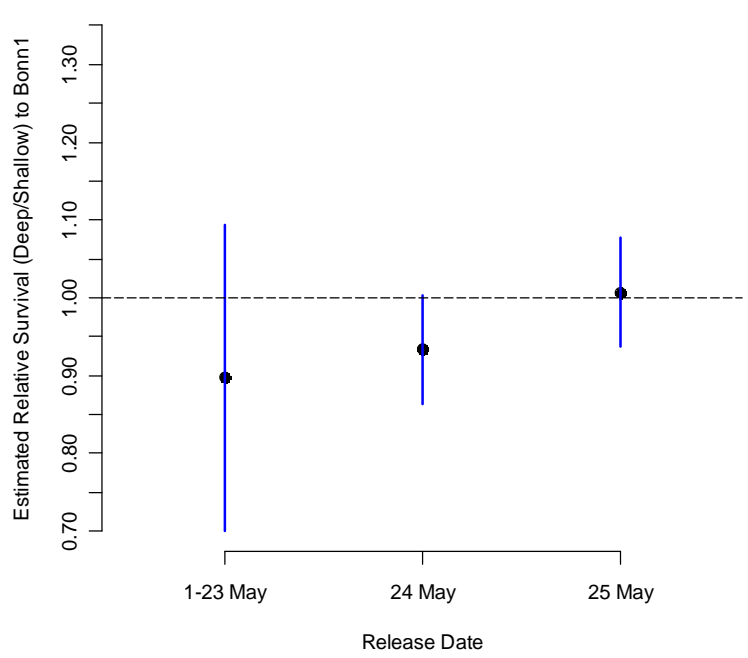

Relative Survival, BON1 to BON2

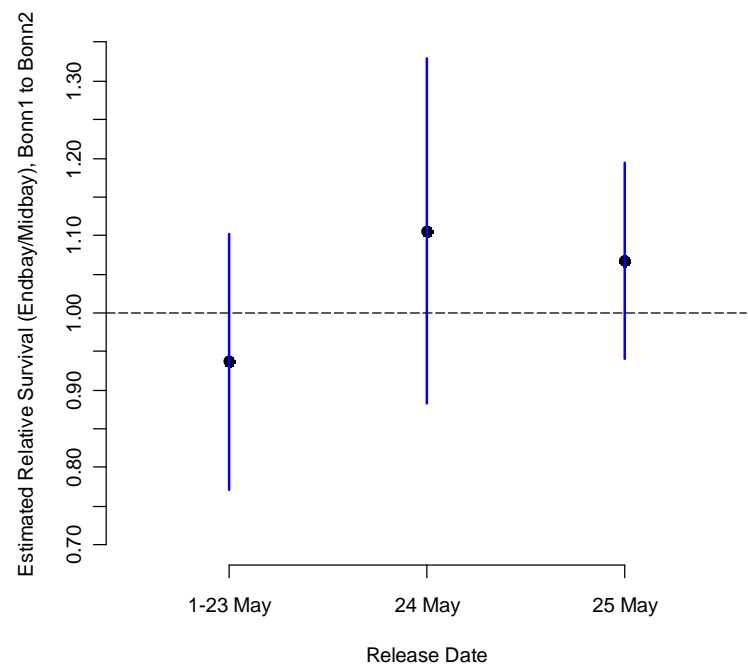

Figure 3.15. Relative Survival of Deep to Shallow Flow Deflector Bay-Passed Spring Chinook Salmon for the (a) Bonneville Dam to BON1 Detection Array and (b) BON1 to BON2 Detection Arrays. Vertical lines indicate 95\% confidence intervals 


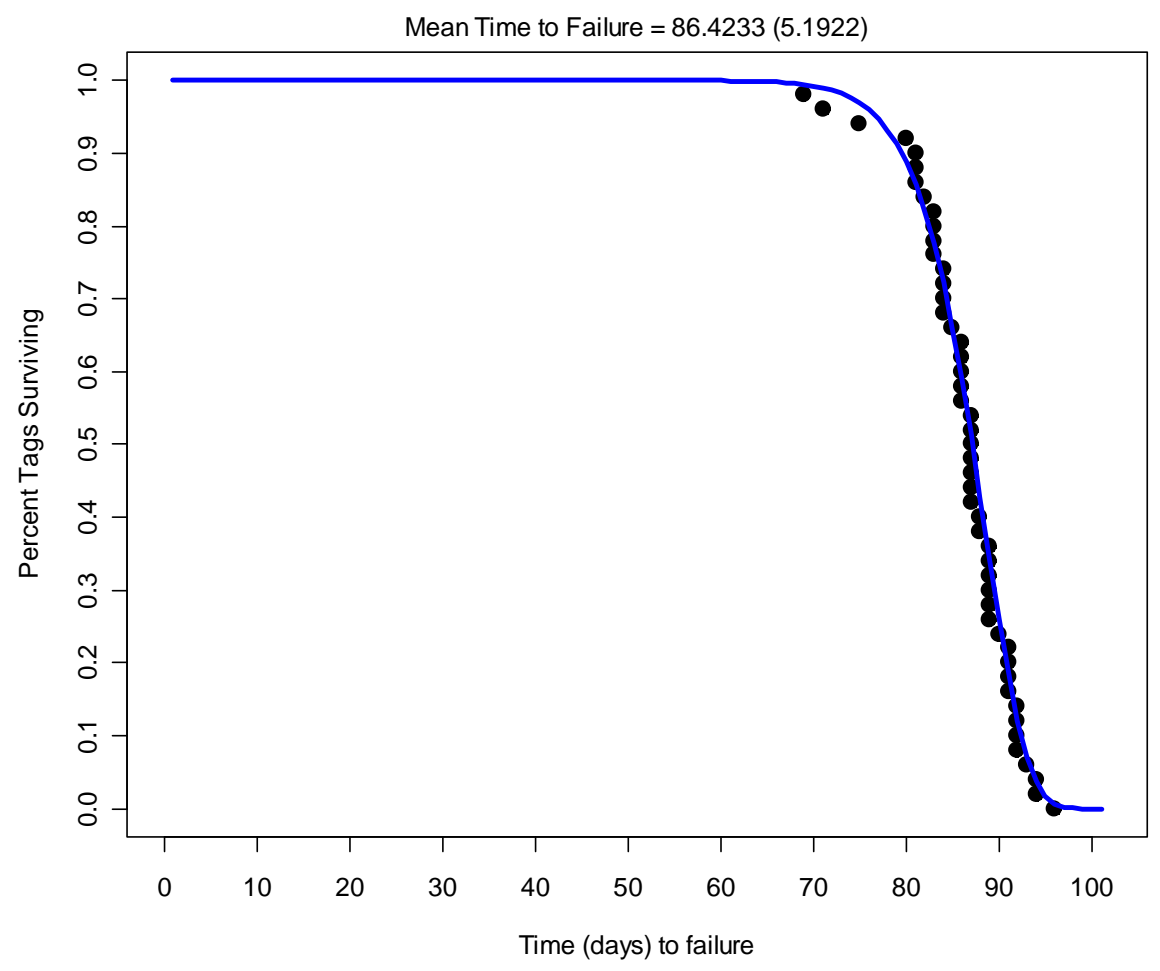

Figure 3.16. Estimated Acoustic-Tag Life of 2007 ATS Acoustic Tags in the Tag-Life Study that Ran Concurrently with the Summer Chinook Salmon Survival Study at Bonneville Dam

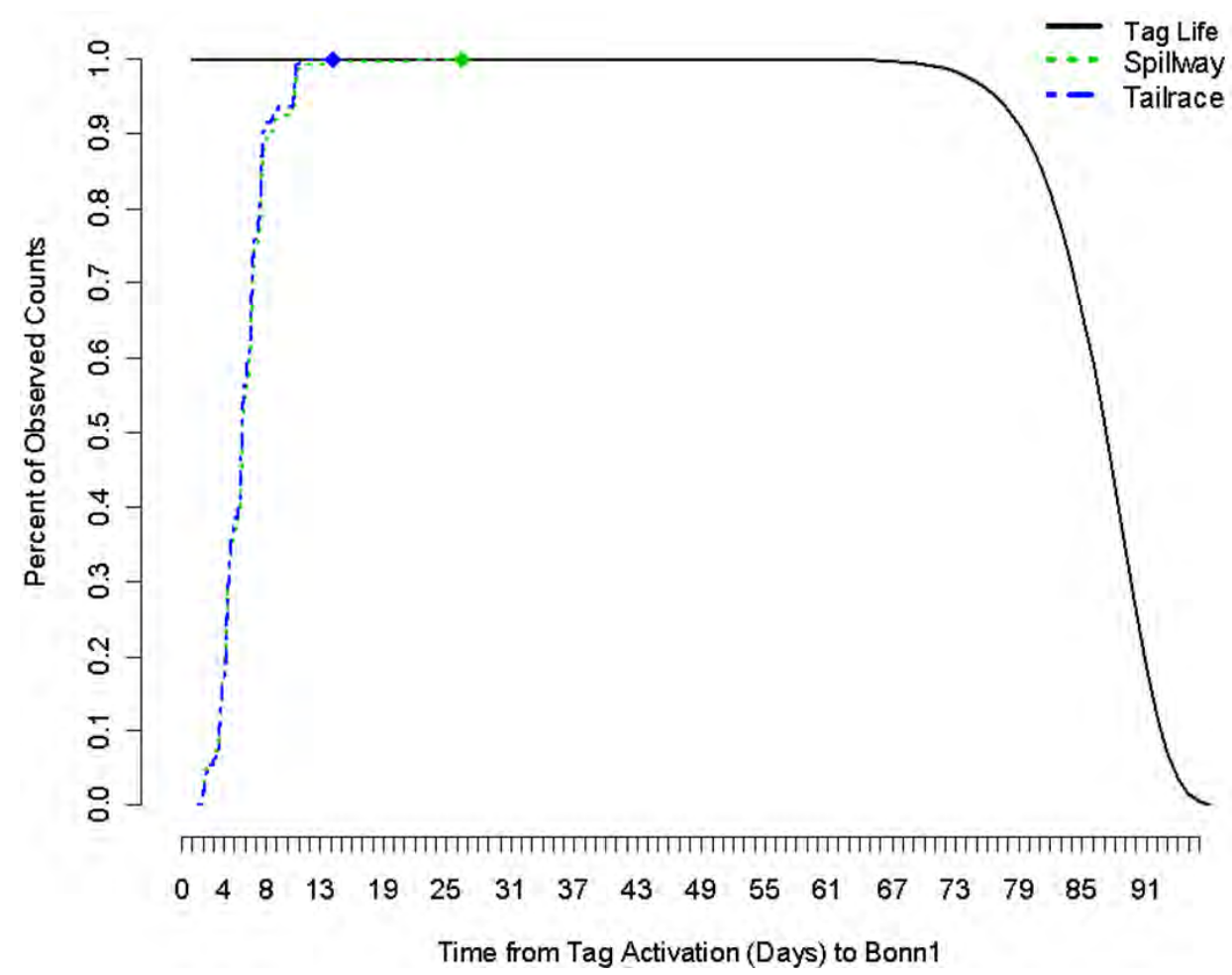

Figure 3.17. Estimated Acoustic-Tag Life of 2007 ATS Acoustic Tags from the Tag-Life Study (black line) and Percent of Released Tags in the Survival Study Detected at BON1 (green and blue lines) 


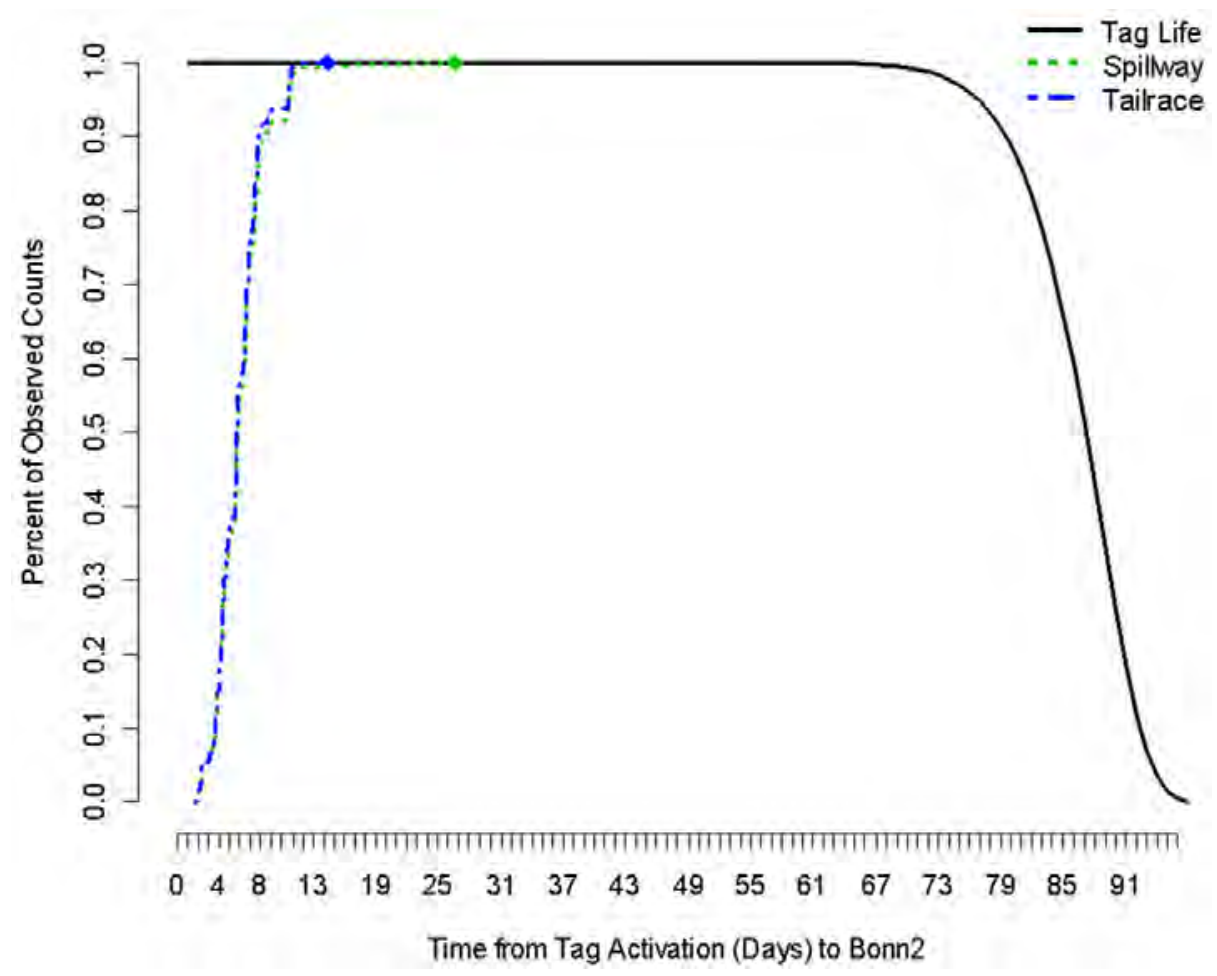

Figure 3.18. Estimated Acoustic-Tag Life of 2007 ATS Acoustic Tags from the Tag-Life Study (black line) and Percent of Released Tags in the Survival Study Detected at BON2 (green and blue lines)

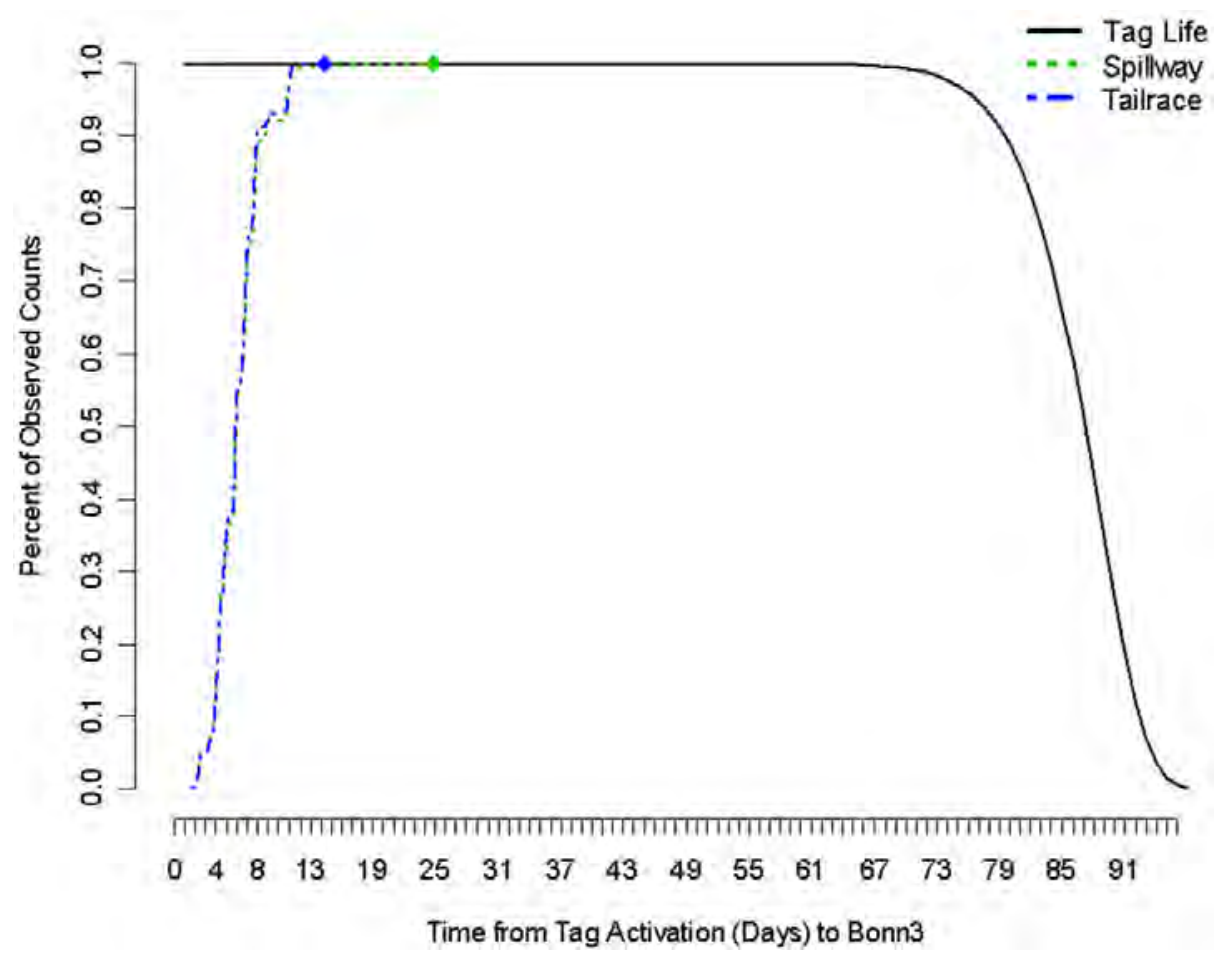

Figure 3.19. Estimated Acoustic-Tag Life of 2007 ATS Acoustic Tags from the Tag-Life Study (black line) and Percent of Released Tags in the Survival Study Detected at BON2 (green and blue lines) 


\subsubsection{Survival of Spillway-Passed Subyearlings}

During 14 releases of smolts, 2921 acoustic-tagged summer Chinook salmon smolts were identified as passing through the spillway at Bonneville Dam in summer (Table 3.17). These 14 releases of smolts were paired daily with 14 releases in the tailrace totaling 1037 fish (Table 3.18). Another seven releases (1751 additional fish into the tailrace as part of the Estuary Survival Study) were not paired by day with forebay releases (Table 3.19).

Table 3.17. Detection Histories on Three Survival Arrays (BON1, BON2, and BON3) for Chinook Salmon Smolts Released in the Spillway Forebay in Summer. Headings of columns 2 through 9 have three digits and each digit represents a detection (1) or non-detection (0) on each of three successive survival arrays (BON1, BON2, and BON3, respectively). A chi-square test for homogeneity of detection histories was highly significant $(\mathrm{P}<0.001)$.

\begin{tabular}{ccccccccccc}
\hline Virtual Release Date & 111 & 011 & 101 & 001 & 110 & 010 & 100 & 000 & Total \\
\hline 21 June 2007 & 173 & 2 & 4 & 1 & 3 & 0 & 2 & 27 & 212 \\
22 June 2007 & 167 & 10 & 8 & 1 & 5 & 1 & 1 & 19 & 212 \\
26 June 2007 & 165 & 6 & 7 & 1 & 8 & 1 & 0 & 19 & 207 \\
27 June 2007 & 173 & 10 & 5 & 0 & 6 & 0 & 0 & 14 & 208 \\
28 June 2007 & 184 & 0 & 4 & 0 & 2 & 0 & 2 & 18 & 210 \\
29 June 2007 & 168 & 1 & 7 & 0 & 5 & 0 & 1 & 22 & 204 \\
3 July 2007 & 187 & 0 & 3 & 0 & 9 & 0 & 0 & 10 & 209 \\
4 July 2007 & 187 & 0 & 3 & 0 & 9 & 0 & 1 & 12 & 212 \\
5 July 2007 & 179 & 0 & 4 & 0 & 15 & 0 & 1 & 9 & 208 \\
6 July 2007 & 170 & 0 & 2 & 0 & 5 & 0 & 1 & 20 & 198 \\
10 July 2007 & 180 & 0 & 1 & 0 & 20 & 0 & 1 & 10 & 212 \\
11 July 2007 & 162 & 1 & 5 & 0 & 29 & 0 & 2 & 13 & 212 \\
12 July 2007 & 158 & 0 & 3 & 0 & 24 & 0 & 8 & 18 & 211 \\
13 July 2007 & 152 & 1 & 3 & 0 & 29 & 0 & 1 & 20 & 206 \\
Pooled & 2405 & 31 & 59 & 3 & 169 & 2 & 21 & 231 & 2921 \\
\hline
\end{tabular}


Table 3.18. Detection Histories on Three Survival Arrays (BON1, BON2, and BON3) for Chinook Salmon Smolts Released in the Tailrace on the Same Days as Forebay Releases in Summer. Headings of columns 2 through 9 have three digits and each digit represents a detection (1) or non-detection (0) on each of three successive survival arrays (BON1, BON2, and BON3, respectively). After eliminating columns with all zero counts, a chi-square test for homogeneity was significant $(\mathrm{P}=0.024)$.

\begin{tabular}{cccccccccc}
\hline Virtual Release Date & 111 & 011 & 101 & 001 & 110 & 010 & 100 & 000 & Total \\
\hline 21 June 2007 & 68 & 1 & 2 & 0 & 2 & 0 & 0 & 1 & 74 \\
22 June 2007 & 66 & 4 & 2 & 0 & 2 & 0 & 0 & 0 & 74 \\
26 June 2007 & 65 & 2 & 1 & 0 & 2 & 0 & 1 & 3 & 74 \\
27 June 2007 & 62 & 2 & 1 & 0 & 2 & 0 & 2 & 5 & 74 \\
28 June 2007 & 66 & 0 & 1 & 0 & 4 & 0 & 1 & 2 & 74 \\
29 June 2007 & 63 & 0 & 2 & 0 & 5 & 0 & 2 & 1 & 73 \\
3 July 2007 & 64 & 0 & 2 & 0 & 6 & 0 & 0 & 2 & 74 \\
4 July 2007 & 67 & 0 & 1 & 0 & 3 & 0 & 1 & 2 & 74 \\
5 July 2007 & 60 & 0 & 1 & 0 & 9 & 0 & 0 & 4 & 74 \\
6 July 2007 & 67 & 0 & 0 & 0 & 2 & 0 & 1 & 3 & 73 \\
10 July 2007 & 68 & 0 & 1 & 0 & 2 & 0 & 2 & 2 & 75 \\
11 July 2007 & 56 & 0 & 4 & 0 & 7 & 0 & 1 & 1 & 69 \\
12 July 2007 & 64 & 0 & 4 & 0 & 10 & 0 & 2 & 0 & 80 \\
13 July 2007 & 64 & 1 & 0 & 0 & 9 & 0 & 1 & 0 & 75 \\
Pooled & 900 & 10 & 22 & 0 & 65 & 0 & 14 & 26 & 1037 \\
\hline
\end{tabular}

Table 3.19. Detection Histories on Three Survival Arrays (BON1, BON2, and BON3) for Chinook Salmon Smolts Released in the Tailrace on Days Without Forebay Releases in Summer. Headings of columns 2 through 9 have three digits and each digit represents a detection (1) or non-detection (0) on each of three successive survival arrays (BON1, BON2, and BON3, respectively).

\begin{tabular}{cccccccccc}
\hline Virtual Release Date & 111 & 011 & 101 & 001 & 110 & 010 & 100 & 000 & Total \\
\hline 16 June 2007 & 219 & 2 & 7 & 0 & 14 & 0 & 0 & 9 & 251 \\
23 June 2007 & 211 & 12 & 10 & 2 & 9 & 1 & 1 & 4 & 250 \\
30 June 2007 & 214 & 2 & 16 & 0 & 15 & 0 & 1 & 2 & 250 \\
7 July 2007 & 209 & 0 & 16 & 0 & 15 & 0 & 0 & 10 & 250 \\
14 July 2007 & 152 & 1 & 30 & 0 & 48 & 0 & 14 & 5 & 250 \\
17 July 2007 & 160 & 1 & 21 & 1 & 53 & 0 & 10 & 4 & 250 \\
21 July 2007 & 196 & 0 & 1 & 0 & 42 & 0 & 4 & 7 & 250 \\
Pooled & 2261 & 28 & 123 & 3 & 261 & 1 & 44 & 67 & 1751 \\
\hline
\end{tabular}


Making use of all capture history data (Table 3.16, Table 3.17, and Table 3.18) violated the assumption of homogeneity of arrivals of treatment and reference released fish at the three survival arrays, but greatly increased the sample size of reference releases. For each replicate release group, separate CJS estimates of survival were computed for spillway (Table 3.20) and tailrace (Table 3.21) releases.

Table 3.20. Cormack-Jolly-Seber Survival and Detection Probabilities (Single Release Estimates) for Spillway-Forebay-Released Subyearling Chinook Salmon Traveling from Bonneville Dam (BON) to Array BON1 and from Arrays BON1 to BON2 by Virtual Release Date. The last column shows $\lambda$, which is the product of survival and detection probabilities for the tertiary array. Numbers in parentheses are standard errors on probabilities.

\begin{tabular}{cccccc}
\hline \multirow{2}{*}{$\begin{array}{c}\text { Virtual Release } \\
\text { Date }\end{array}$} & \multicolumn{2}{c}{ Survival } & \multicolumn{2}{c}{ Detection } & $\begin{array}{c}\text { Combination of } \\
\text { Survival to and } \\
\text { Detection at } \\
\text { BON3 }\end{array}$ \\
\cline { 2 - 4 } 21 June 2007 & $0.873(0.023)$ & $0.989(0.008)$ & $0.984(0.009)$ & $0.972(0.012)$ & $0.983(0.010)$ \\
\hline 22 June 2007 & $0.911(0.020)$ & $0.996(0.006)$ & $0.938(0.017)$ & $0.952(0.016)$ & $0.967(0.013)$ \\
\hline 26 June 2007 & $0.908(0.020)$ & $1.002(0.001)$ & $0.957(0.015)$ & $0.955(0.015)$ & $0.950(0.016)$ \\
27 June 2007 & $0.933(0.017)$ & $1.001(0.001)$ & $0.948(0.016)$ & $0.973(0.012)$ & $0.968(0.013)$ \\
\hline 28 June 2007 & $0.914(0.019)$ & $0.990(0.007)$ & $1.000(<0.001)$ & $0.979(0.011)$ & $0.989(0.008)$ \\
\hline 29 June 2007 & $0.892(0.022)$ & $0.996(0.006)$ & $0.994(0.006)$ & $0.960(0.015)$ & $0.971(0.013)$ \\
\hline 3 July 2007 & $0.952(0.015)$ & $1.001(<0.001)$ & $1.000(<0.001)$ & $0.984(0.009)$ & $0.954(0.015)$ \\
\hline 4 July 2007 & $0.943(0.016)$ & $0.996(0.005)$ & $1.000(<0.001)$ & $0.984(0.009)$ & $0.954(0.015)$ \\
\hline 5 July 2007 & $0.957(0.014)$ & $0.997(0.005)$ & $1.000(<0.001)$ & $0.978(0.011)$ & $0.923(0.019)$ \\
\hline 6 July 2007 & $0.899(0.021)$ & $0.995(0.006)$ & $1.000(<0.001)$ & $0.988(0.008)$ & $0.971(0.013)$ \\
\hline 10 July 2007 & $0.953(0.015)$ & $0.996(0.005)$ & $1.000(<0.001)$ & $0.994(0.006)$ & $0.900(0.021)$ \\
\hline 11 July 2007 & $0.939(0.016)$ & $0.994(0.007)$ & $0.995(0.005)$ & $0.970(0.013)$ & $0.849(0.026)$ \\
12 July 2007 & $0.915(0.019)$ & $0.961(0.014)$ & $1.000(<0.001)$ & $0.981(0.011)$ & $0.868(0.025)$ \\
\hline 13 July 2007 & $0.903(0.021)$ & $0.998(0.006)$ & $0.995(0.005)$ & $0.981(0.011)$ & $0.841(0.027)$ \\
\hline Weighted Avg. & $0.930(0.007)$ & $1.001(0.001)$ & & & \\
\hline
\end{tabular}


The spillway and tailrace releases were not always synchronized in time when all data were included, so we estimated spillway survival based on the quotient of weighted-average survival estimates for the season, as follows:

$$
\hat{S}_{\text {Spill }}=\frac{\left[\frac{\Sigma w_{i} \hat{S}_{\text {Forebay }, i}}{\Sigma w_{i}}\right]}{\left[\frac{\Sigma w_{i} \hat{S}_{\text {Tailrace }}}{\Sigma w_{i}}\right]}
$$

where $w_{i}$ is the number of fish released each day and $\hat{s}$ is survival. Using all available data (Table 3.20, Table 3.21), PR survival was estimated to be $\hat{s}_{\text {spul }}=0.930(\widehat{\mathrm{sE}}=0.007)$ in summer.

Using only the forebay and tailrace releases that could be paired on a daily basis during the common period of June 21 to July 13, the quotient of weighted-average survivals produced an estimate of $\hat{s}_{\text {Spill }}=0.930(\widehat{\mathrm{SE}}=0.007)$. Regardless of the range of releases, a 95\% confidence interval for spillway passage survival would be approximately 0.917-0.945.

Table 3.21. Cormack-Jolly-Seber Survival and Detection Probabilities (Single-Release Estimates) for Tailrace-Released Subyearling Chinook Salmon Traveling from Bonneville Dam (BON) to Array BON1 and from Arrays BON1 to BON2 by Virtual Release Date. The last column shows $\lambda$, which is the product of survival and detection probabilities for the tertiary array. Numbers in parentheses are standard errors on probabilities.

\begin{tabular}{|c|c|c|c|c|c|}
\hline \multirow{2}{*}{$\begin{array}{c}\text { Virtual Release } \\
\text { Date }\end{array}$} & \multicolumn{2}{|c|}{ Survival } & \multicolumn{2}{|c|}{ Detection } & \multirow{2}{*}{$\begin{array}{l}\text { Combination of } \\
\text { Survival to and } \\
\text { Detection at } \\
\text { BON3 }\end{array}$} \\
\hline & BON to BON1 & BON1 to BON2 & BON to BON1 & BON1 to BON2 & \\
\hline 16 June 2007 & $0.964(0.012)$ & $1.002(0.001)$ & $0.992(0.006)$ & $0.969(0.011)$ & $0.940(0.015)$ \\
\hline 21 June 2007 & $0.986(0.013)$ & $1.001(0.001)$ & $0.986(0.014)$ & $0.972(0.020)$ & $0.972(0.020)$ \\
\hline 22 June 2007 & $1.000(<0.001)$ & $1.001(0.001)$ & $0.946(0.026)$ & $0.972(0.019)$ & 0.972 (0.019) \\
\hline 23 June 2007 & $0.984(0.008)$ & $0.998(0.004)$ & $0.939(0.015)$ & $0.949(0.014)$ & $0.957(0.013)$ \\
\hline 26 June 2007 & $0.960(0.023)$ & $0.986(0.014)$ & $0.971(0.020)$ & $0.985(0.015)$ & $0.971(0.020)$ \\
\hline 27 June 2007 & $0.933(0.029)$ & $0.971(0.021)$ & $0.970(0.021)$ & $0.985(0.015)$ & $0.970(0.021)$ \\
\hline 28 June 2007 & $0.973(0.019)$ & $0.987(0.014)$ & $1.000(<0.001)$ & $0.985(0.015)$ & $0.943(0.028)$ \\
\hline 29 June 2007 & $0.986(0.014)$ & $0.974(0.019)$ & $1.000(<0.001)$ & $0.969(0.021)$ & $0.926(0.032)$ \\
\hline 30 June 2007 & $0.992(0.006)$ & $1.000(0.004)$ & $0.992(0.006)$ & $0.931(0.017)$ & $0.935(0.016)$ \\
\hline 3 July 2007 & $0.973(0.019)$ & $1.003(0.002)$ & $1.000(<0.001)$ & $0.970(0.021)$ & $0.914(0.033)$ \\
\hline
\end{tabular}


Table 3.21. (contd)

\begin{tabular}{|c|c|c|c|c|c|}
\hline \multirow{2}{*}{$\begin{array}{c}\text { Virtual Release } \\
\text { Date }\end{array}$} & \multicolumn{2}{|c|}{ Survival } & \multicolumn{2}{|c|}{ Detection } & \multirow{2}{*}{$\begin{array}{c}\text { Combination o } \\
\text { Survival to anc } \\
\text { Detection at } \\
\text { BON3 }\end{array}$} \\
\hline & BON to BON1 & BON1 to BON2 & BON to BON1 & BON1 to BON2 & \\
\hline 4 July 2007 & $0.973(0.019)$ & $0.987(0.014)$ & $1.000(<0.001)$ & $0.985(0.015)$ & $0.957(0.024)$ \\
\hline 5 July 2007 & $0.946(0.026)$ & $1.002(0.002)$ & $1.000(<0.001)$ & $0.984(0.016)$ & $0.870(0.041)$ \\
\hline 6 July 2007 & $0.959(0.023)$ & $0.986(0.014)$ & $1.000(<0.001)$ & $1.000(<0.001)$ & $0.971(0.020)$ \\
\hline 7 July 2007 & $0.960(0.012)$ & $1.005(0.002)$ & $1.000(<0.001)$ & 0.929 (0.017) & $0.933(0.017)$ \\
\hline 10 July 2007 & $0.973(0.019)$ & 0.973 (0.019) & $1.000(<0.001)$ & $0.986(0.014)$ & $0.971(0.020)$ \\
\hline 11 July 2007 & $0.986(0.014)$ & $0.993(0.015)$ & $1.000(<0.001)$ & $0.933(0.032)$ & $0.889(0.040)$ \\
\hline 12 July 2007 & $1.000(<0.001)$ & $0.983(0.018)$ & $1.000(<0.001)$ & $0.941(0.029)$ & $0.865(0.040)$ \\
\hline 13 July 2007 & $1.000(<0.001)$ & $0.986(0.013)$ & $0.986(0.013)$ & $1.000(<0.001)$ & $0.878(0.038)$ \\
\hline 14 July 2007 & $0.980(0.009)$ & $0.981(0.018)$ & $0.996(0.004)$ & $0.836(0.027)$ & $0.761(0.030)$ \\
\hline 17 July 2007 & $0.984(0.008)$ & $0.988(0.015)$ & $0.992(0.006)$ & $0.880(0.024)$ & $0.752(0.030)$ \\
\hline 21 July 2007 & $0.972(0.010)$ & $0.984(0.008)$ & $1.000(<0.001)$ & $0.995(0.005)$ & $0.824(0.025)$ \\
\hline Weighted Avg. & $0.999(0.001)$ & $1.001(0.001)$ & & & \\
\hline
\end{tabular}

\subsubsection{Comparison of Deep Versus Shallow Flow Deflector Bays in Summer}

During 14 summer trials, 1105 summer Chinook salmon smolts were identified going through shallow flow deflector bays (Table 3.22) and 892 were identified going through deep flow deflector spill bays (Table 3.23). Chi-square tests of homogeneity found the survival and detection processes for the replicate trials to be significantly different $(\mathrm{P}<0.001)$, precluding pooling of the data over the season. Using the single-release-recapture model, reach survival estimates were calculated for each of the shallow flow deflector (Table 3.24) and deep flow deflector (Table 3.25) virtual releases. For the shallow flow deflector releases, a weighted-average survival from Bonneville Dam to the primary downstream array was $0.936(\widehat{\mathrm{SE}}=0.008)$. For the deep flow deflector releases, the weighted-average survival for that same initial reach was $0.999(\widehat{\mathrm{SE}}=0.002)$. For both treatment groups, reach survival between primary and secondary arrays was estimated to be 1.0. Combining the results that could be paired (Table 3.24 and Table 3.25), relative survivals for deep-to-shallow deflector spill bay passage were estimated by replicate trials (Table 3.26). Using a weighted average of the individual relative survival estimates across trials produced an estimate of RS1 $=1.025(\widehat{\mathrm{SE}}=0.009)$ from Bonneville Dam to the primary array (CI [1.006 $<$ RS1 < 1.044] = 0.95). These results are consistent with the alternative hypothesis (Equation 2.5) that survival through spill bays containing the deep flow deflectors would be better than through those containing shallow flow deflectors. For the reach between primary and secondary arrays, relative survival of fish passing through spill bays containing of deep to shallow flow deflectors was estimated to be 
RS2 $=0.999(\widehat{\mathrm{SE}}=0.001$; Table 3.26). Figure 3.20 plots the individual estimates of relative survival by trial for the first and second reaches below Bonneville Dam. For the first reach, 8 of 14 ratio estimates exceeded 1, 4 of 14 were close to 1 , and only 2 were below 1 . For the second reach, the pattern of deviations did not have a positive or negative tendency.

Table 3.22. Shallow Flow Deflector (i.e., bays 4 through 15 with deflectors at elevation 4.267 m above MSL) Summer Chinook Salmon Detection Histories at BON1, BON2, and BON3.

Headings of columns 2 through 9 have three digits and each digit represents a detection (1) or non-detection (0) on each of three successive survival arrays (BON1, BON2, and BON3, respectively).

\begin{tabular}{cccccccccc}
\hline Virtual Release Date & 111 & 011 & 101 & 001 & 110 & 010 & 100 & 000 & Total \\
\hline 21 June 2007 & 40 & 1 & 2 & 0 & 0 & 0 & 1 & 6 & 50 \\
22 June 2007 & 35 & 3 & 2 & 0 & 3 & 0 & 0 & 4 & 47 \\
26 June 2007 & 34 & 0 & 3 & 0 & 2 & 0 & 0 & 5 & 44 \\
27 June 2007 & 37 & 2 & 0 & 0 & 0 & 0 & 0 & 4 & 43 \\
28 June 2007 & 33 & 0 & 0 & 0 & 0 & 0 & 0 & 6 & 39 \\
29 June 2007 & 37 & 0 & 1 & 0 & 0 & 0 & 0 & 4 & 42 \\
3 July 2007 & 62 & 0 & 1 & 0 & 4 & 0 & 0 & 2 & 69 \\
4 July 2007 & 83 & 0 & 0 & 0 & 0 & 0 & 0 & 5 & 88 \\
5 July 2007 & 97 & 0 & 2 & 0 & 9 & 0 & 1 & 5 & 114 \\
6 July 2007 & 53 & 0 & 0 & 0 & 0 & 0 & 0 & 6 & 59 \\
10 July 2007 & 89 & 0 & 1 & 0 & 10 & 0 & 0 & 5 & 105 \\
11 July 2007 & 84 & 0 & 3 & 0 & 15 & 0 & 1 & 6 & 109 \\
12 July 2007 & 113 & 0 & 2 & 0 & 16 & 0 & 3 & 12 & 146 \\
13 July 2007 & 110 & 1 & 0 & 0 & 22 & 0 & 1 & 16 & 150 \\
Pooled & 907 & 7 & 17 & 0 & 81 & 0 & 7 & 86 & 1105 \\
\hline
\end{tabular}

Table 3.23. Deep Flow Deflector (i.e., bays 1 through 3 and 16 through 18 with deflectors at elevation 2.134 m above MSL) Summer Chinook Salmon Detection Histories at BON1, BON2, and BON3. Headings of columns 2 through 9 have three digits and each digit represents a detection (1) or non-detection (0) on each of three successive survival arrays (BON1, BON2, and BON3, respectively).

\begin{tabular}{cccccccccc}
\hline Virtual Release Date & 111 & 011 & 101 & 001 & 110 & 010 & 100 & 000 & Total \\
\hline 21 June 2007 & 76 & 1 & 2 & 1 & 2 & 0 & 1 & 13 & 96 \\
22 June 2007 & 71 & 2 & 3 & 1 & 1 & 0 & 0 & 7 & 85 \\
26 June 2007 & 51 & 3 & 2 & 0 & 2 & 0 & 0 & 6 & 64 \\
27 June 2007 & 59 & 3 & 2 & 0 & 6 & 0 & 0 & 4 & 74 \\
\hline
\end{tabular}


Table 3.23. (contd)

\begin{tabular}{cccccccccc}
\hline Virtual Release Date & 111 & 011 & 101 & 001 & 110 & 010 & 100 & 000 & Total \\
\hline 28 June 2007 & 85 & 0 & 2 & 0 & 0 & 0 & 1 & 4 & 92 \\
29 June 2007 & 67 & 1 & 2 & 0 & 2 & 0 & 1 & 8 & 81 \\
3 July 2007 & 52 & 0 & 0 & 0 & 2 & 0 & 0 & 3 & 57 \\
4 July 2007 & 42 & 0 & 1 & 0 & 7 & 0 & 1 & 2 & 53 \\
5 July 2007 & 45 & 0 & 1 & 0 & 3 & 0 & 0 & 1 & 50 \\
6 July 2007 & 76 & 0 & 1 & 0 & 2 & 0 & 1 & 8 & 88 \\
10 July 2007 & 47 & 0 & 0 & 0 & 6 & 0 & 1 & 2 & 56 \\
11 July 2007 & 36 & 1 & 0 & 0 & 7 & 0 & 0 & 0 & 44 \\
12 July 2007 & 17 & 0 & 1 & 0 & 3 & 0 & 1 & 2 & 24 \\
13 July 2007 & 17 & 0 & 3 & 0 & 5 & 0 & 0 & 3 & 28 \\
Pooled & 741 & 11 & 20 & 2 & 48 & 0 & 7 & 63 & 892 \\
\hline
\end{tabular}

Table 3.24. Single-Release Estimates of Survival and Detection Probabilities for Subyearling Chinook Salmon that Passed Through Bays with Shallow Flow Deflectors Based on Detection Histories for Arrays BON1, BON2, and BON3. These were spill bays 4 through 5 that had deflectors at elevation $4.267 \mathrm{~m}$ above MSL. Numbers in parentheses are standard errors.

\begin{tabular}{|c|c|c|c|c|c|}
\hline \multirow{2}{*}{$\begin{array}{c}\text { Virtual Release } \\
\text { Date }\end{array}$} & \multicolumn{2}{|c|}{ Survival } & \multicolumn{2}{|c|}{ Detection } & \multirow{2}{*}{$\begin{array}{c}\text { Combination of } \\
\text { Survival to and } \\
\text { Detection at } \\
\text { BON3 }\end{array}$} \\
\hline & BON to BON1 & BON1 to BON2 & BON1 & BON2 & \\
\hline 21 June 2007 & $0.880(0.046)$ & $0.977(0.023)$ & $0.977(0.023)$ & $0.953(0.032)$ & $1.000(<0.001)$ \\
\hline 22 June 2007 & $0.915(0.041)$ & $1.004(0.003)$ & $0.930(0.039)$ & $0.950(0.034)$ & $0.927(0.041)$ \\
\hline 26 June 2007 & $0.886(0.048)$ & $1.005(0.004)$ & $1.000(<0.001)$ & $0.919(0.045)$ & $0.944(0.038)$ \\
\hline 27 June 2007 & $0.907(0.044)$ & $1.000(<0.001)$ & $0.949(0.035)$ & $1.000(<0.001)$ & $1.000(<0.001)$ \\
\hline 28 June 2007 & $0.846(0.058)$ & $1.000(<0.001)$ & $1.000(<0.001)$ & $1.000(<0.001)$ & $1.000(<0.001)$ \\
\hline 29 June 2007 & $0.905(0.045)$ & $1.000(<0.001)$ & $1.000(<0.001)$ & $0.974(0.026)$ & $1.000(<0.001)$ \\
\hline 3 July 2007 & $0.971(0.020)$ & $1.001(0.001)$ & $1.000(<0.001)$ & $0.984(0.016)$ & $0.939(0.029)$ \\
\hline 4 July 2007 & $0.943(0.025)$ & $1.000(<0.001)$ & $1.000(<0.001)$ & $1.000(<0.001)$ & $1.000(<0.001)$ \\
\hline 5 July 2007 & $0.956(0.019)$ & $0.993(0.009)$ & $1.000(<0.001)$ & $0.980(0.014)$ & $0.915(0.027)$ \\
\hline 6 July 2007 & $0.898(0.039)$ & $1.000(<0.001)$ & $1.000(<0.001)$ & $1.000(<0.001)$ & $1.000(<0.001)$ \\
\hline 10 July 2007 & $0.952(0.021)$ & $1.001(0.001)$ & $1.000(<0.001)$ & $0.989(0.011)$ & $0.899(0.030)$ \\
\hline 11 July 2007 & $0.945(0.022)$ & $0.995(0.010)$ & $1.000(<0.001)$ & $0.966(0.020)$ & $0.848(0.036)$ \\
\hline 12 July 2007 & $0.918(0.023)$ & $0.980(0.013)$ & $1.000(<0.001)$ & $0.983(0.012)$ & $0.876(0.029)$ \\
\hline 13 July 2007 & $0.893(0.025)$ & $0.992(0.007)$ & $0.992(0.007)$ & $1.000(<0.001)$ & $0.835(0.032)$ \\
\hline Weighted Avg. & $0.936(0.008)$ & $1.000(<0.001)$ & & & \\
\hline
\end{tabular}


Table 3.25. Single-Release Estimates of Survival and Detection Probabilities for Subyearling Chinook Salmon that Passed Through Bays with Deep Flow Deflectors Based on Detection Histories for Arrays BON1, BON2, and BON3. These were spill bays 1 through 3 and 16 through 18 that had deflectors at elevation $2.134 \mathrm{~m} \mathrm{ft}$ above MSL. Numbers in parentheses are standard errors.

\begin{tabular}{clllll}
\hline \multirow{2}{*}{\begin{tabular}{c} 
Virtual Release $\begin{array}{c}\text { Survival } \\
\text { Date }\end{array}$ \\
\cline { 2 - 6 }
\end{tabular}} & BON to BON1 & $\begin{array}{c}\text { BON1 to } \\
\text { BON2 }\end{array}$ & BON1 & BON2 & $\begin{array}{c}\text { Combination of } \\
\text { Survival to and } \\
\text { Detection at } \\
\text { BON3 }\end{array}$ \\
\hline 21 June 2007 & $0.865(0.035)$ & $0.989(0.012)$ & $0.976(0.017)$ & $0.963(0.021)$ & $0.975(0.018)$ \\
22 June 2007 & $0.918(0.030)$ & $1.001(0.001)$ & $0.962(0.022)$ & $0.948(0.025)$ & $0.986(0.013)$ \\
26 June 2007 & $0.906(0.036)$ & $1.001(0.001)$ & $0.948(0.029)$ & $0.964(0.025)$ & $0.964(0.025)$ \\
27 June 2007 & $0.946(0.026)$ & $1.003(0.002)$ & $0.957(0.024)$ & $0.969(0.022)$ & $0.912(0.034)$ \\
28 June 2007 & $0.957(0.021)$ & $0.989(0.011)$ & $1.000(<0.001)$ & $0.977(0.016)$ & $1.000(<0.001)$ \\
29 June 2007 & $0.901(0.033)$ & $0.987(0.014)$ & $0.986(0.014)$ & $0.971(0.020)$ & $0.971(0.020)$ \\
3 July 2007 & $0.947(0.030)$ & $1.000(<0.001)$ & $1.000(<0.001)$ & $1.000(<0.001)$ & $0.963(0.026)$ \\
4 July 2007 & $0.962(0.026)$ & $0.984(0.020)$ & $1.000(<0.001)$ & $0.977(0.023)$ & $0.857(0.050)$ \\
5 July 2007 & $0.980(0.020)$ & $1.001(0.002)$ & $1.000(<0.001)$ & $0.978(0.022)$ & $0.938(0.035)$ \\
6 July 2007 & $0.909(0.031)$ & $0.988(0.012)$ & $1.000(<0.001)$ & $0.987(0.013)$ & $0.974(0.018)$ \\
10 July 2007 & $0.964(0.025)$ & $0.981(0.018)$ & $1.000(<0.001)$ & $1.000(<0.001)$ & $0.887(0.044)$ \\
11 July 2007 & $1.000(<0.001)$ & $1.000(<0.001)$ & $0.977(0.022)$ & $1.000(<0.001)$ & $0.841(0.055)$ \\
12 July 2007 & $0.917(0.056)$ & $0.963(0.046)$ & $1.000(<0.001)$ & $0.944(0.054)$ & $0.850(0.080)$ \\
13 July 2007 & $0.893(0.058)$ & $1.035(0.026)$ & $1.000(<0.001)$ & $0.850(0.080)$ & $0.773(0.089)$ \\
Weighted Avg. & $0.999(0.002)$ & $1.001(<0.001)$ & & & \\
\hline
\end{tabular}

Table 3.26. Relative Survival (Deep/Shallow) by Release Pair for the First and Second Reaches

\begin{tabular}{ccc}
\hline & \multicolumn{2}{c}{ Relative Survival } \\
\cline { 2 - 3 } Virtual Release Date & BON to BON1 & BON1 to BON2 \\
\hline 21 June 2007 & $0.983(0.065)$ & $1.012(0.027)$ \\
22 June 2007 & $1.003(0.056)$ & $0.997(0.003)$ \\
26 June 2007 & $1.023(0.069)$ & $0.996(0.004)$ \\
27 June 2007 & $1.043(0.058)$ & $1.003(0.002)$ \\
28 June 2007 & $1.131(0.081)$ & $0.989(0.011)$ \\
29 June 2007 & $0.996(0.062)$ & $0.987(0.014)$ \\
3 July 2007 & $0.975(0.037)$ & $0.999(0.001)$ \\
4 July 2007 & $1.020(0.039)$ & $0.984(0.020)$ \\
\hline
\end{tabular}


Table 3.26. (contd)

\begin{tabular}{ccc}
\hline & \multicolumn{2}{c}{ Relative Survival } \\
\cline { 2 - 3 } Virtual Release Date & BON to BON1 & BON1 to BON2 \\
\hline 5 July 2007 & $1.025(0.029)$ & $1.008(0.009)$ \\
6 July 2007 & $1.012(0.056)$ & $0.988(0.012)$ \\
10 July 2007 & $1.013(0.035)$ & $0.980(0.018)$ \\
11 July 2007 & $1.058(0.025)$ & $1.005(0.010)$ \\
12 July 2007 & $0.999(0.066)$ & $0.983(0.049)$ \\
13 July 2007 & $1.000(0.071)$ & $1.043(0.027)$ \\
Weighted Average & $1.025(0.009)$ & $0.999(0.001)$ \\
\hline
\end{tabular}

Using an ANODEV based on the reach survival estimates (Table 3.24, Table 3.25) and a log-link, normal error structure and unweighted analysis, differences in survival between shallow and deep flow deflector passage routes were compared. An unweighted analysis was performed because the weights were poorly estimated as a result of small sample sizes in some cases. The shallow flow deflector spill bays had a significantly lower passage survival than the deep flow deflector spill bays in the first reach ( $\left.t_{26}=-2.538, P=0.0087\right)$. This result is expected under the alternative hypothesis where deep flow deflector spill bays have higher passage survival. In the second reach, deep flow deflector spill bays did not have a significant increase in survival compared to shallow flow deflector spill bays $(P=0.9736)$.

These ANODEV results were confirmed using the estimates of relative survival (Table 3.26) based on a log-link, normal error structure and weighting by $1 / \mathrm{CV}^{2}$. Survivals were significantly different in the first reach $\left(t_{26}=2.505, P=0.0188\right)$ but not in the second reach $\left(t_{26}=-0.650, P=0.5212\right)$. Again, spill bays containing deep flow deflectors had higher passage survival in the first reach than those containing shallow flow deflectors.

a. Relative Survival, Release to BON1

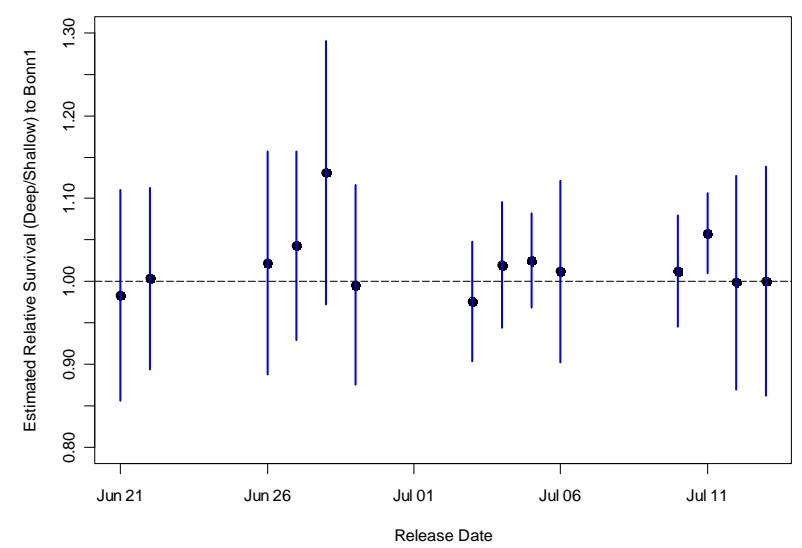

b. Relative Survival, BON1 to BON2

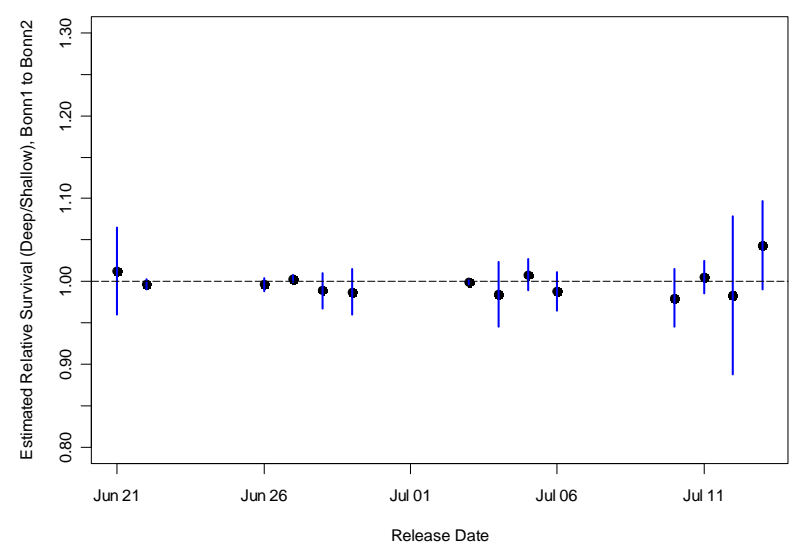

Figure 3.20. Summer Chinook Salmon Relative Survival Estimates by Trial (Deep/Shallow) for (a) Release to BON1 and (b) BON1 to BON2 Detection Arrays. Vertical lines indicate the 95\% confidence intervals. 


\subsection{Summary of Survival Results}

The 2007 project provided estimates of absolute spillway passage survival and relative survival for deep versus shallow flow deflector bays (Table 3.27). Survival was about $3 \%$ higher in spring than it was in summer, and in summer, when tailrace elevations were lower, survival for subyearling Chinook salmon passing through end bays with deep flow deflectors was higher than survival of subyearlings passing through bays with shallow flow deflectors.

Table 3.27. Summary of Absolute (Paired Release) and Relative (i.e., Deep/Shallow) Survival at Bonneville Spillway in 2007, Standard Errors (SEs), and 95\% Confidence Intervals (CIs)

\begin{tabular}{ccc}
\hline Response & Spring & Summer \\
\hline $\begin{array}{c}\text { Spillway } \\
\text { Survival }\end{array}$ & $0.944(\widehat{\mathrm{SE}}=0.013)^{(\mathrm{a})} \mathrm{CI}(0.918 \leq S \leq 0.959)=0.95$ & $0.930(\widehat{\mathrm{SE}}=0.007)$ \\
& $0.957(\widehat{\mathrm{SE}}=0.012)^{(\mathrm{b})} \mathrm{CI}(0.931 \leq S \leq 0.983)=0.95$ & $\mathrm{CI}(0.917 \leq S \leq 0.945)=0.95$ \\
$\begin{array}{l}\text { Relative } \\
\begin{array}{l}\text { Survival } \\
(\text { Deep/shallow })\end{array}\end{array}$ & $0.969(\widehat{\mathrm{SE}}=0.028) \mathrm{CI}\left(0.849 \leq R S_{1} \leq 1.089\right)=0.95$ & $1.025(\widehat{\mathrm{SE}}=0.009) \mathrm{CI}(1.006 \leq S \leq 1.044)=0.95$ \\
\hline
\end{tabular}

(a) Adjusted for tag life of 2007 SC tag lots and one dead-fish detection.

(b) Adjusted for tag life of 2007 SC tag lots only.

\subsection{Tests of Survival-Model Assumptions}

Results from Burnham and arrival distribution tests are described in the following sections.

\subsubsection{Burnham Test Results}

The following tables (Table 3.28 through Table 3.35) display the $P$-values from the Burnham tests that could be estimated under the 2007 study design, grouped by run (spring or summer Chinook salmon). Spring Chinook salmon were tagged with acoustic tags that had different expected tag lives, and consequently, tag-life corrections were required. Burnham tests were thus further split by tag year (2006 or 2007). For the most part, the Burnham tests indicated that the study assumptions were not violated. However, a number of spring Chinook salmon release groups using the 2007 SC acoustic tag rejected the Burnham 2.2 (5 groups) and 3.1 (8 groups) tests. A large number of tests could not be conducted, especially on the summer Chinook salmon data because of the high detection rates observed at BON1 and BON2 acoustic arrays. 
Table 3.28. Results (i.e., P-values) of Burnham et al. (1987) Tests 1.T2 and 1.T3 for Equal Detection and Survival Probabilities at Downriver Detection Sites for the Spring Chinook Salmon that Were Used in the Bonneville Dam Mid-Bay and End-Bay Spill Release Groups

\begin{tabular}{ccc}
\hline & \multicolumn{2}{c}{$P$-values } \\
\cline { 2 - 3 } Release Date & BON1 (1.T2) & BON2 (1.T3) \\
\hline 16-23 May & 0.969 & 0.789 \\
24 May & 0.545 & 0.974 \\
25 May & 0.931 & 0.982 \\
\hline
\end{tabular}

Table 3.29. Results (i.e., $P$-values) of Burnham et al. (1987) Tests 2 and 3 for Goodness-of-Fit to the Single-Release-Recapture Assumptions for the Spring Chinook Salmon that Were Used in the Bonneville Dam Mid-Bay and End-Bay Spill Release Groups. NA indicates that a $P$-value could not be estimated

\begin{tabular}{cccccc}
\hline & Burnham Tests & \multicolumn{3}{c}{ Burnham Tests } \\
\hline Middle Bay & 2.2 & 3.1 & End Bay & 2.2 & 3.1 \\
\hline 16-23 May & 0.799 & 0.608 & $16-23$ May & NA & NA \\
24 May & 0.171 & 0.716 & 24 May & 0.644 & 0.947 \\
25 May & 0.706 & 0.409 & 25 May & 0.765 & 0.746 \\
\hline
\end{tabular}

Table 3.30. Results (i.e., P-values) of Burnham et al. (1987) Tests 1.T2 and 1.T3 for Equal Detection and Survival Probabilities at Downriver Detection Sites for the Spring Chinook Salmon that Were Used in the Bonneville Dam Spillway and Tailrace Release Groups. Shaded cells indicate rejected homogeneous capture and survival rates at or below BON1 or BON2 arrays at $\alpha=0.10$. NA indicates that the P-value could not be estimated.

\begin{tabular}{rcc}
\hline & \multicolumn{2}{c}{$P$-values } \\
\cline { 2 - 3 } Release Date & BON1 (1.T2) & BON2 (1.T3) \\
\hline & SC 2006 Tags & \\
22 May 2007 & 0.713 & 0.142 \\
25 May 2007 & 0.546 & 0.826 \\
\hline
\end{tabular}


Table 3.30. (contd)

\begin{tabular}{lcl}
\hline & \multicolumn{2}{c}{$P$-values } \\
\cline { 2 - 3 } Release Date & BON1 (1.T2) & BON2 (1.T3) \\
\hline & SC 2007 Tags & 0.465 \\
1 May 2007 & 0.527 & 0.783 \\
2 May 2007 & 0.611 & 0.734 \\
3 May 2007 & NA & 0.052 \\
4 May 2007 & 0.764 & 0.647 \\
8 May 2007 & 0.599 & 0.203 \\
9 May 2007 & 0.898 & 0.367 \\
10 May 2007 & 0.956 & 0.641 \\
11 May 2007 & 0.009 & 0.990 \\
15 May 2007 & 0.764 & 0.229 \\
16 May 2007 & 0.931 & 0.866 \\
17 May 2007 & 0.875 & 0.845 \\
18 May 2007 & 0.910 & 0.723 \\
22 May 2007 & 0.757 & 0.837 \\
23 May 2007 & 0.985 & 0.858 \\
24 May 2007 & 0.042 & \\
25 May 2007 & 0.191 & \\
\hline
\end{tabular}

Table 3.31. Results (i.e., P-values) of Burnham et al. (1987) Tests 2 and 3 for Goodness-of-Fit to the Single-Release-Recapture Assumptions for the Spring Chinook Salmon that Were Used in the Bonneville Dam Pooled Spillway and Tailrace Release Groups. Shaded cells indicate rejected homogeneous capture and survival rates at or below BON1 or BON2 arrays at $\alpha=0.10$. NA indicates that the P-value could not be estimated.

\begin{tabular}{crrrrrr}
\hline \multicolumn{2}{c}{ Burnham Tests } & \multicolumn{2}{c}{ Burnham Tests } \\
\hline Spillway & 2.2 & 3.1 & Tailrace & 2.2 & 3.1 \\
\hline & \multicolumn{3}{c}{ SC 2006 Tags } \\
22 May 2007 & 0.693 & 0.706 & 22 May 2007 & 0.936 & 0.884 \\
25 May 2007 & 0.960 & 0.535 & 25 May 2007 & 0.357 & 0.833 \\
\hline
\end{tabular}


Table 3.31. (contd)

\begin{tabular}{|c|c|c|c|c|c|}
\hline \multicolumn{4}{|c|}{ Burnham Tests } & \multicolumn{2}{|c|}{ Burnham Tests } \\
\hline Spillway & 2.2 & 3.1 & Tailrace & 2.2 & 3.1 \\
\hline \multicolumn{6}{|c|}{ SC 2007 Tags } \\
\hline 1 May 2007 & 0.180 & 0.003 & 1 May 2007 & 0.335 & 0.090 \\
\hline 2 May 2007 & 0.171 & 0.747 & 2 May 2007 & 0.182 & 0.768 \\
\hline 3 May 2007 & NA & NA & 3 May 2007 & NA & NA \\
\hline 4 May 2007 & 0.753 & 0.298 & 4 May 2007 & 0.034 & 0.295 \\
\hline 8 May 2007 & 0.967 & 0.596 & 8 May 2007 & 0.601 & 0.020 \\
\hline 9 May 2007 & 0.748 & 0.005 & 9 May 2007 & 0.808 & 0.778 \\
\hline 10 May 2007 & 0.510 & 0.682 & 10 May 2007 & 0.010 & 0.015 \\
\hline \multirow[t]{2}{*}{11 May 2007} & 0.413 & 0.642 & 11 May 2007 & 0.619 & 0.243 \\
\hline & & & 12 May 2007 & 0.008 & 0.539 \\
\hline 15 May 2007 & 0.594 & 0.548 & 15 May 2007 & 0.968 & 0.825 \\
\hline 16 May 2007 & 0.670 & 0.745 & 16 May 2007 & 0.009 & 0.768 \\
\hline 17 May 2007 & 0.162 & 0.353 & 17 May 2007 & 0.960 & 0.845 \\
\hline \multirow[t]{2}{*}{18 May 2007} & 0.993 & 0.062 & 18 May 2007 & 0.619 & 0.631 \\
\hline & & & 19 May 2007 & 0.814 & 0.422 \\
\hline 22 May 2007 & 0.474 & 0.531 & 22 May 2007 & 0.786 & 0.975 \\
\hline 23 May 2007 & 0.023 & 0.468 & 23 May 2007 & 0.564 & 0.359 \\
\hline 24 May 2007 & 0.964 & 0.079 & 24 May 2007 & 0.206 & 0.586 \\
\hline \multirow[t]{2}{*}{25 May 2007} & 0.786 & 0.966 & 25 May 2007 & 0.311 & 0.756 \\
\hline & & & 2 June 2007 & 0.874 & $<0.001$ \\
\hline
\end{tabular}


Table 3.32. Results (i.e., P-values) of Burnham et al. (1987) Tests 1.T2 and 1.T3 for Equal Detection and Survival Probabilities at Downriver Detection Sites for the Summer Chinook Salmon that Were Used in the Bonneville Dam Mid-Bay and End-Bay Spill Release Groups. Shaded cells indicate rejected homogeneous capture and survival rates at or below BON1 or BON2 arrays at $\alpha=0.10$. NA indicates that the P-value could not be estimated.

\begin{tabular}{lcc}
\hline & & P-values \\
\cline { 2 - 3 } Release Date & BON1 (1.T2) & BON2 (1.T3) \\
\hline 21 June & 0.572 & 0.833 \\
22 June & 0.748 & 0.748 \\
26 June & 0.398 & 0.647 \\
27 June & 0.783 & 0.748 \\
28 June & NA & 0.936 \\
29 June & 0.739 & 0.568 \\
3 July & NA & 0.914 \\
4 July & NA & 0.797 \\
5 July & NA & 0.583 \\
6 July & NA & 0.840 \\
10 July & NA & 0.746 \\
11 July & 0.660 & 0.607 \\
12 July & NA & 0.885 \\
13 July & 0.345 & 0.001 \\
\hline
\end{tabular}


Table 3.33. Results (i.e., P-values) of Burnham et al. (1987) Tests 2 and 3 for Goodness-of-Fit to the Single-Release-Recapture Assumptions for the Summer Chinook Salmon that Were Used in the Bonneville Dam Mid-Bay and End-Bay Spill Release Groups. Shaded cells indicate rejected homogeneous capture and survival rates at or below BON1 or BON2 arrays at $\alpha=0.10$. NA indicates that a P-value could not be estimated.

\begin{tabular}{|c|c|c|c|c|c|}
\hline \multicolumn{3}{|c|}{ Burnham Tests } & \multicolumn{3}{|c|}{ Burnham Tests } \\
\hline Middle Bay & 2.2 & 3.1 & End Bay & 2.2 & 3.1 \\
\hline 21 June & 0.029 & NA & 21 June & 0.104 & 0.002 \\
\hline 22 June & 0.306 & 0.518 & 22 June & 0.355 & 0.003 \\
\hline 26 June & NA & NA & 26 June & 0.198 & 0.209 \\
\hline 27 June & NA & NA & 27 June & 0.142 & 0.624 \\
\hline 28 June & NA & NA & 28 June & NA & NA \\
\hline 29 June & NA & NA & 29 June & 0.004 & 0.004 \\
\hline 3 July & NA & NA & 3 July & NA & NA \\
\hline 4 July & NA & NA & 4 July & NA & NA \\
\hline 5 July & NA & NA & 5 July & NA & NA \\
\hline 6 July & NA & NA & 6 July & NA & NA \\
\hline 10 July & NA & NA & 10 July & NA & NA \\
\hline 11 July & NA & NA & 11 July & NA & 0.346 \\
\hline 12 July & NA & NA & 12 July & NA & NA \\
\hline 13 July & NA & 0.366 & 13 July & NA & NA \\
\hline
\end{tabular}


Table 3.34. Results (i.e., P-values) of Burnham et al. (1987) Tests 1.T2 and 1.T3 for Equal Detection and Survival Probabilities at Downriver Detection Sites for the Summer Chinook Salmon that Were Used in the Bonneville Dam Spillway and Tailrace Release Groups (Same Day). NA indicates that the P-value could not be estimated.

\begin{tabular}{lll}
\hline & & P-values \\
\cline { 2 - 3 } Release Date & BON1 (1.T2) & BON2 (1.T3) \\
\hline 21 June & 0.680 & 0.674 \\
22 June & 0.970 & 0.700 \\
\hline 26 June & 0.861 & 0.472 \\
27 June & 0.663 & 0.970 \\
28 June & NA & 0.887 \\
29 June & 0.630 & 0.994 \\
3 July & NA & 0.861 \\
4 July & NA & 0.608 \\
5 July & NA & 0.842 \\
6 July & NA & 0.923 \\
10 July & NA & 0.972 \\
11 July & NA & 0.646 \\
12 July & 0.907 & 0.343 \\
\hline 13uly & & 0.573 \\
\hline
\end{tabular}


Table 3.35. Results (i.e., P-values) of Burnham et al. (1987) Tests 2 and 3 for Goodness-of-Fit to the Single-Release-Recapture Assumptions for the Summer Chinook Salmon that were Used in the Bonneville Dam Spillway and Tailrace Release Groups. Shaded cells indicate rejected homogeneous capture and survival rates at or below BON1 or BON2 arrays at $\alpha=0.10$. NA indicates that a P-value could not be estimated.

\begin{tabular}{|c|c|c|c|c|c|}
\hline \multicolumn{3}{|c|}{ Burnham Tests } & \multicolumn{3}{|c|}{ Burnham Tests } \\
\hline Spillway & 2.2 & 3.1 & Tailrace & 2.2 & 3.1 \\
\hline & & & 16 June & 0.061 & 0.253 \\
\hline 21 June & 0.135 & 0.010 & 21 June & 0.004 & 0.004 \\
\hline \multirow[t]{2}{*}{22 June } & 0.930 & 0.808 & 22 June & 0.214 & 0.223 \\
\hline & & & 23 June & 0.345 & 0.935 \\
\hline 26 June & 0.775 & 0.791 & 26 June & 0.004 & 0.059 \\
\hline 27 June & 0.620 & 0.735 & 27 June & 0.005 & 0.066 \\
\hline 28 June & NA & NA & 28 June & NA & NA \\
\hline \multirow[t]{2}{*}{29 June } & 0.016 & 0.005 & 29 June & NA & NA \\
\hline & & & 30 June & 0.285 & 0.286 \\
\hline 3 July & NA & NA & 3 July & NA & NA \\
\hline 4 July & NA & NA & 4 July & NA & NA \\
\hline 5 July & NA & NA & 5 July & NA & NA \\
\hline \multirow[t]{2}{*}{6 July } & NA & NA & 6 July & NA & NA \\
\hline & & & 7 July & NA & NA \\
\hline 10 July & NA & NA & 10 July & NA & NA \\
\hline 11 July & 0.002 & 0.329 & 11 July & NA & NA \\
\hline 12 July & NA & NA & 12 July & NA & NA \\
\hline \multirow[t]{4}{*}{13 July } & $<0.001$ & 0.351 & 13 July & NA & 0.244 \\
\hline & & & 14 July & 0.270 & 0.539 \\
\hline & & & 17 July & 0.444 & 0.558 \\
\hline & & & 21 July & NA & NA \\
\hline
\end{tabular}




\subsubsection{Arrival Distribution Tests}

Detection counts from each release were grouped according to travel time to each array, in 4-hour time blocks. Releases used in the deep versus shallow flow spill bay passage study were released at approximately the same time. Releases in the tailrace were delayed an hour after the forebay release groups to better synchronize passage for the spillway absolute survival study. Both runs of Chinook salmon displayed very similar arrival distributions to each array for each release site comparison (yearlings in Figure 3.21 and Figure 3.22 and subyearlings in Figure 3.23 and Figure 3.24).
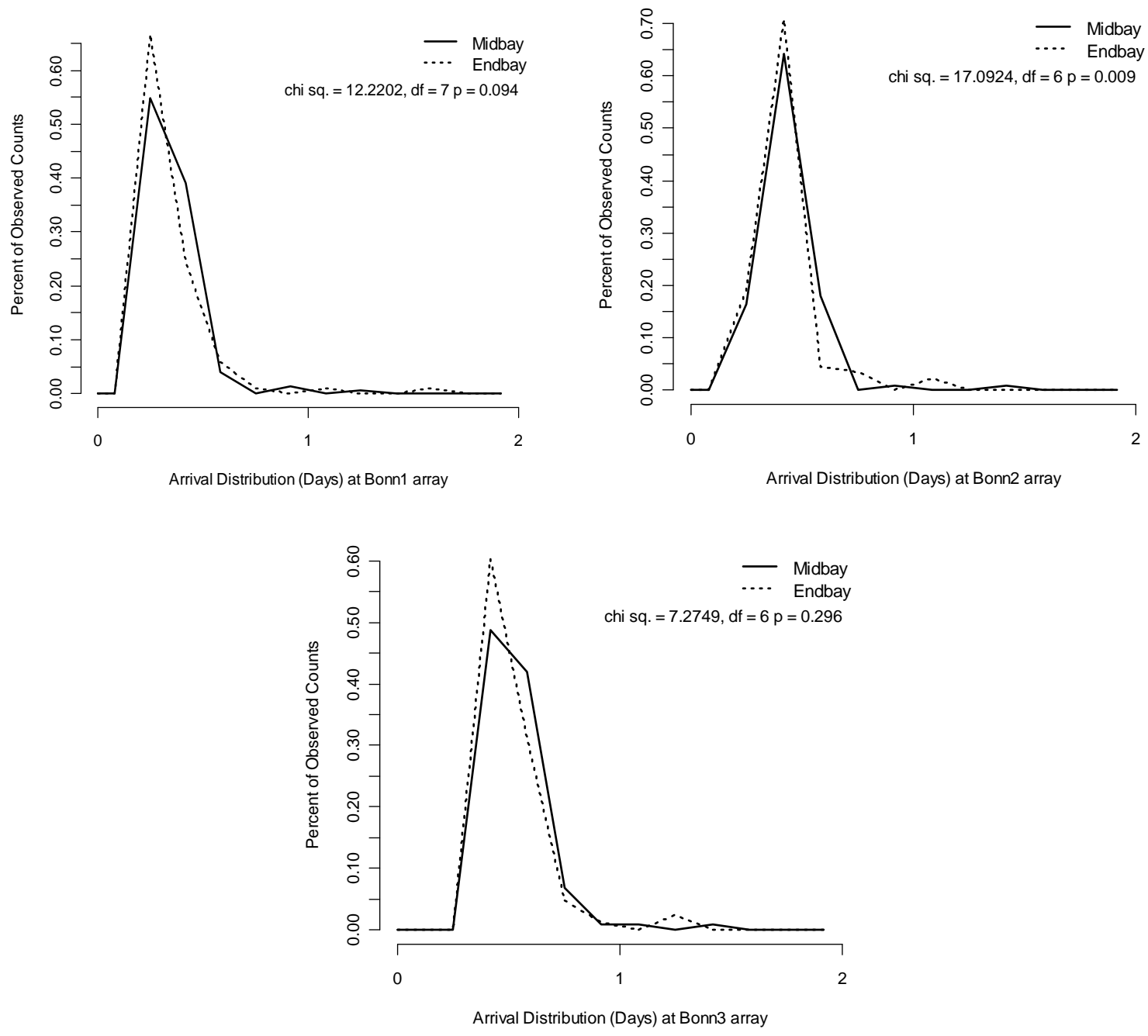

Figure 3.21. Arrival Distributions at BON1, BON2, and BON3 Arrays for the Spring Chinook Salmon that Were Used in the Bonneville Dam Mid-Bay and End-Bay Spill Release Groups. Arrival distributions were based on travel times. 

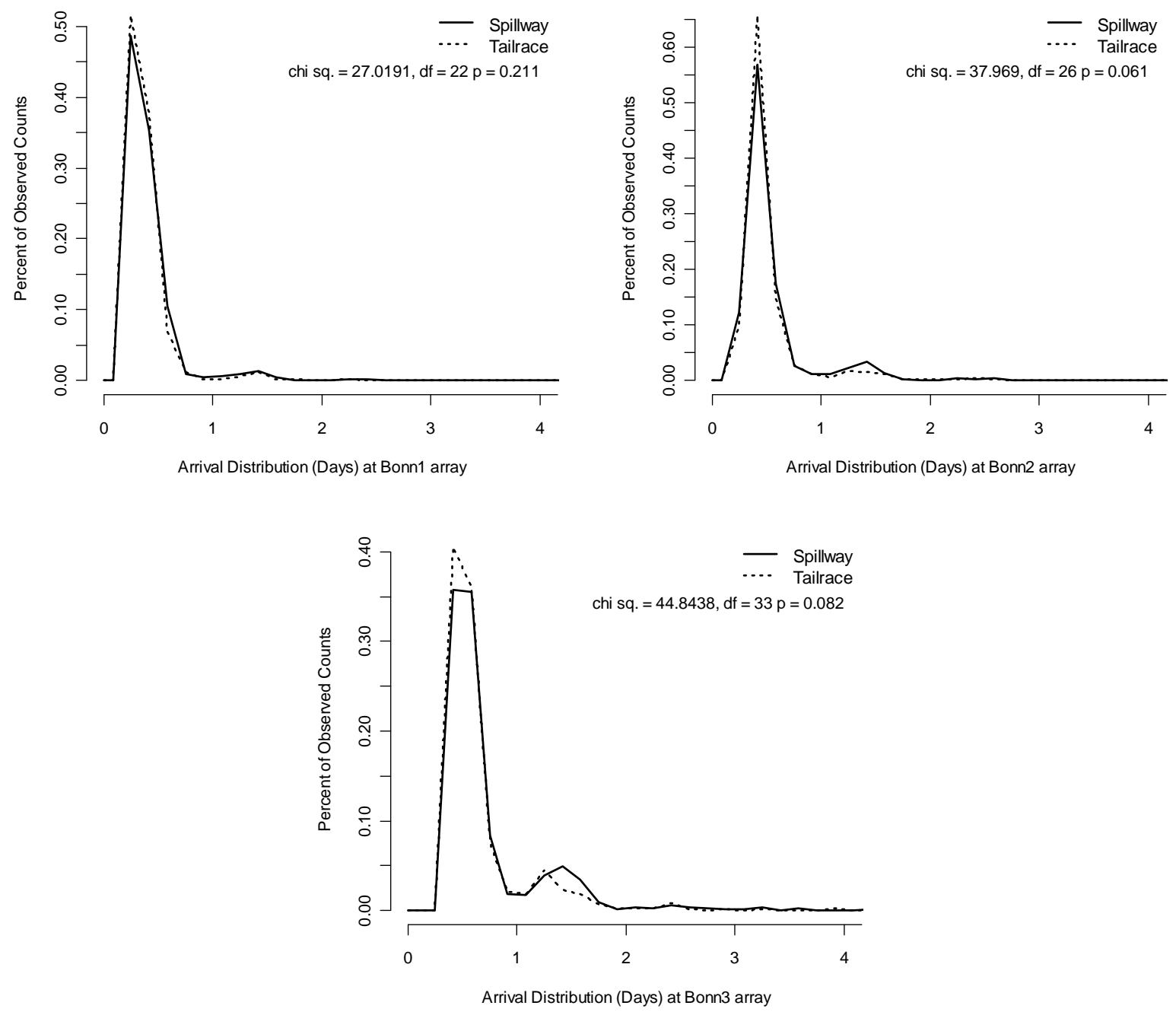

Figure 3.22. Arrival Distributions at BON1, BON2, and BON3 Arrays for the Spring Chinook Salmon that Were Used in the Bonneville Dam Spillway and Tailrace Release Groups. Arrival distributions were based on travel times, and only tailrace release groups that were paired with a spillway release were used in this comparison. 

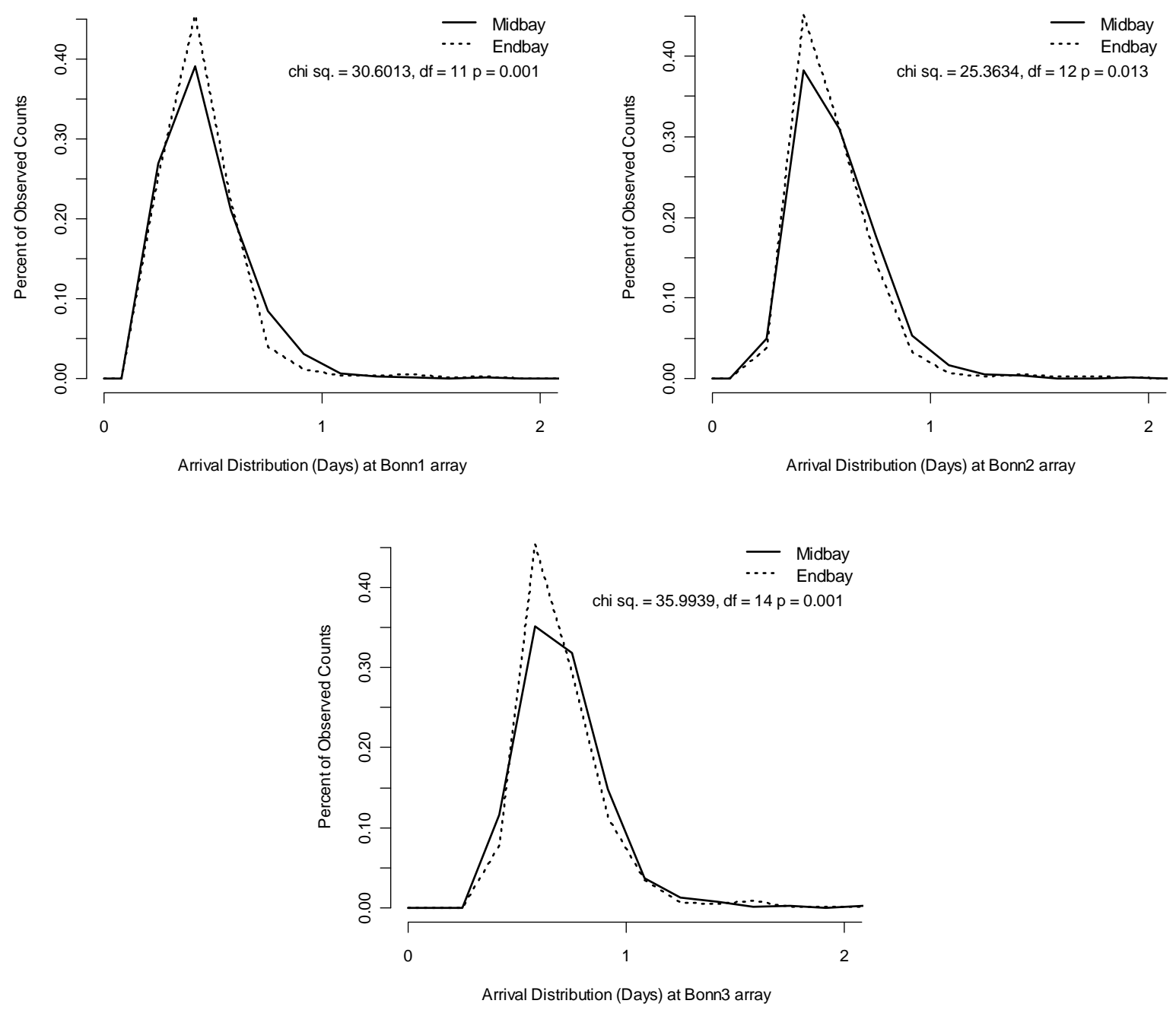

Figure 3.23. Arrival Distributions at BON1, BON2, and BON3 Arrays for the Summer Chinook Salmon that Were Used in the Bonneville Dam Mid-Bay and End-Bay Spill Release Groups. Arrival distributions were based on travel times. 

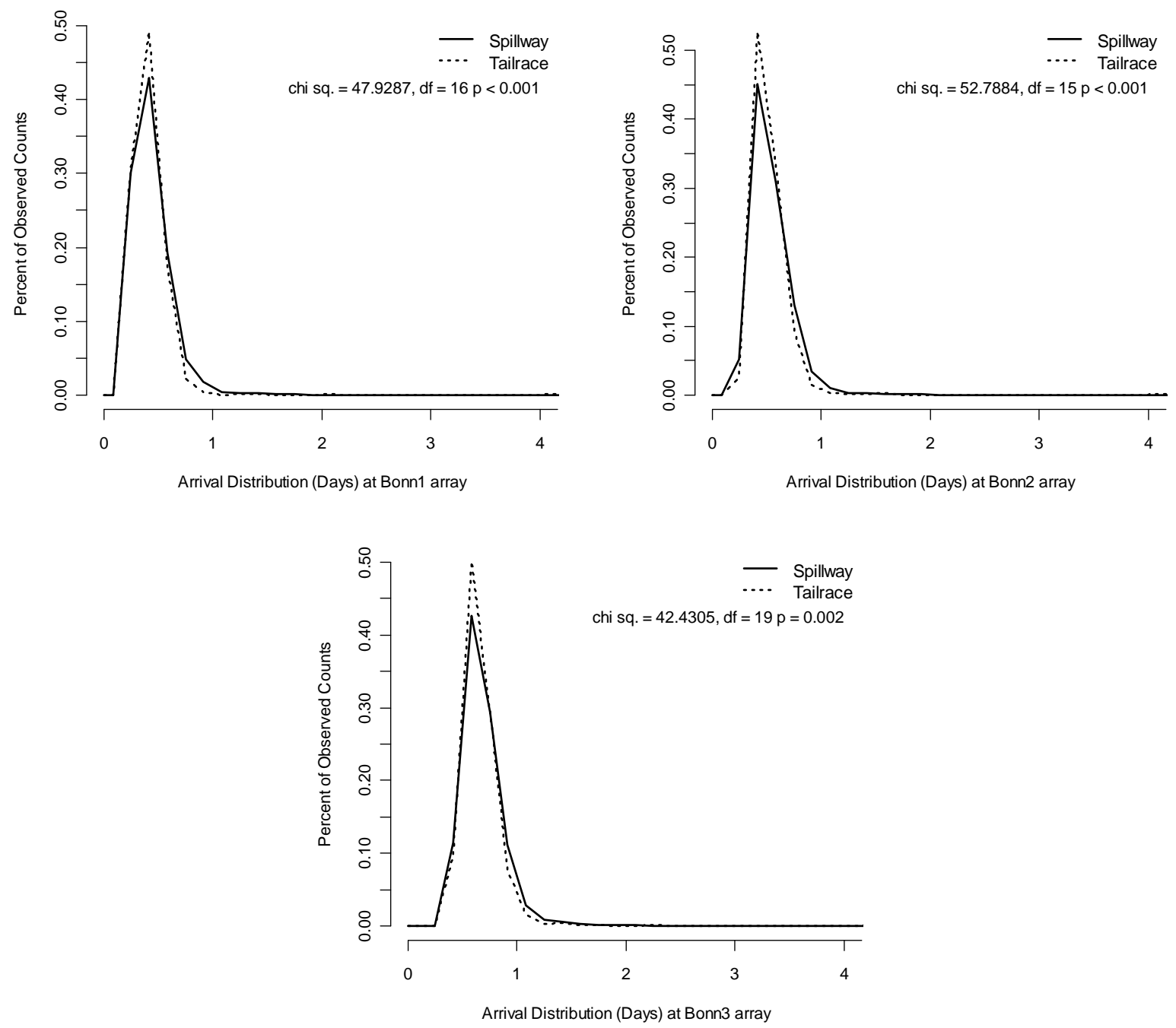

Figure 3.24. Arrival Distributions at BON1, BON2, and BON3 Arrays for the Summer Chinook Salmon that Were Used in the Bonneville Dam Spillway and Tailrace Release Groups. Arrival distributions were based on travel times, and only tailrace release groups that were paired with a spillway release were used in this comparison. 



\subsection{Discussion}

The environment and 2007 outmigration conditions are discussed first in this section, followed by sections on single dead-fish detection, the detection performance of the spillway cabled array, the detection performance of the downstream array, the fish egress rates, the detection and survival of yearling and subyearling Chinook in the spring and summer, respectively, the summary results of 2007 survivals, and the tests of survival model assumptions.

\subsection{Environment and 2007 Outmigration Conditions}

Environmental conditions, including discharge, temperature and tailrace elevation, and 2007 outmigration conditions, including run timing, smolt species composition, and length frequencies, are discussed here.

\subsubsection{Project Discharge, Temperature, and Tailrace Elevation}

The most likely environmental conditions reducing survival of subyearling Chinook salmon passing bays with shallow flow deflectors are below-average project discharge and low-tailrace elevations in summer (see Figure 3.1 and Figure 3.3). Below-average project discharge resulted in low-tailwater elevations that were often within $1 \mathrm{~m}$ of shallow flow deflectors in summer (Figure 3.3). In contrast, project discharge was similar to the 10-year average in spring, and tailrace elevations were mostly in the range of 6.1 to $7.01 \mathrm{~m}$ above MSL. The lowest tailrace elevations observed for about 4 days in spring were at least $5.5 \mathrm{~m}$ above MSL, and we observed no significant difference in survival of fish passing bays with shallow and deep flow deflectors, although statistical power was poor during spring.

Mechanisms for increased mortality when tailrace elevations are within $1 \mathrm{~m}$ of shallow flow deflectors at middle bays are unknown, but we can speculate that the proximity of fish to deflector surfaces decreases as the amount of water passing over deflectors decreases. Any injury or loss of equilibrium associated with abrasion or shear could increase the susceptibility of fish to predation or disease so there could be immediate or delayed mortality.

Observed water temperatures were below critical levels for juvenile Chinook salmon (Brett 1952). Higher water temperatures may increase susceptibility to disease (Tiffan et al. 2000) and may be an additional stressor on young Chinook salmon, particularly those that are not well fed (Cobleigh 2003), but not if exposure and assessment times are short. We released treatment fish directly into the spillway forebay, and all fish passed the dam and survival arrays in $<24$ hours. Water temperatures probably had less effect on survival in 2007 than in some years because temperatures were within $1{ }^{\circ} \mathrm{C}$ of the 10 -year average in spring and most of summer and did not reach $20.5{ }^{\circ} \mathrm{C}$ until the last couple of days of summer releases.

\subsubsection{Run Timing and Smolt Species Composition}

Tagging and release seasons occurred when more than $70 \%$ of the spring run of juvenile Chinook salmon and more than $61 \%$ of the summer run were passing Bonneville Dam. The spring release season ran from May 1 to May 25, 2007, and yearling Chinook salmon releases began when about 20\% of the 
run had passed the dam and ended when $93.6 \%$ of the run had passed. The summer release season ran from June 21 to July 13, 2007. Excluding spring hatchery releases of subyearlings before May 18, the summer run began when about 14\% of the fish had passed Bonneville Dam and ended after about $75 \%$ had passed. The 2007 study exceeded its goal of releasing fish during at least the central $50 \%$ of each run.

Yearling Chinook salmon made up just 50\% of all juvenile salmonids migrating in spring 2007 and $67 \%$ of juvenile salmonids if we ignore the $25 \%$ contributed by hatchery-released subyearling Chinook salmon. Either way, this study provides no inference about the survival of a sizable percentage of the migrating juvenile salmon in spring.

\subsubsection{Length Frequencies}

No yearlings were rejected from tagging based on length because all yearlings exceeded the 95-mm minimum length requirement, and the distributions of lengths of yearling fish that were tagged and that were routinely sampled for smolt monitoring were very similar.

In contrast, the 95-mm minimum tagging length effectively eliminated about $40 \%$ of the run-of-river subyearlings from the tagging sample because they were too small to be eligible for tagging. This is less than the percentage excluded by a 130-mm-length-limit criterion, which excluded 55 to $60 \%$ of the runof-river subyearlings from tagging in a 2005 radiotelemetry study, but it is still too high. Tagging would need to include 75- to 95-mm-long subyearlings to be fully representative of the population passing through the B2 JMF in summer 2007. Tagging subyearlings $75 \mathrm{~mm}$ long will require further miniaturization of tags and reduction in tag weight, according to results of a 2007 tag-effects study (Richard Brown, Personal Communication, 2007). The summer length limitation for tagging restricted our statistical inference to the larger subyearlings in the JMF samples. Length-related detection biases associated with acoustic telemetry have not yet been documented like those for PIT-tag detection systems (Zabel et al. 2005), although this bias should not be large, if it exists at all, because detection probabilities like those observed for releases down to the primary array below Bonneville Dam were very high (mean probability $=92.7 \%$ ). The detection probability to the secondary array averaged $87.5 \%$.

Collection of fish exclusively from the B2 JMF also could limit inference about survival to the population of bypassed fish, which may or may not be representative of the entire run migrating seaward. According to previous route-specific survival studies, the percentage of yearling Chinook salmon passing Bonneville Dam through the B2 JMF was just 12.4\% in spring 2004 (Reagan et al. 2006) and 15\% in spring 2005 (Adams et al. 2006). For subyearlings, only 8.4\% passed through the B2 JMF in summer 2004 (Evans et al. 2006), and only 6.7\% passed there in 2005 (Adams et al. 2006).

\subsection{Dead-Fish Detection}

Trends in the rate of travel of the single dead fish detected on the egress, primary, secondary, and four subsequent arrays (Table 3.1) suggest that it was hung up before reaching the egress array but then floated and travelled about the speed of the current to within $47 \mathrm{~km}$ of Astoria, Oregon. The last detection on the Cathlamet, Washington Array, which was located $177 \mathrm{~km}$ downstream of Bonneville Dam, indicates that relocating study survival arrays much farther downstream than $42 \mathrm{~km}$ would not have prevented this detection. 
The problem with correcting overall spillway survival estimates for detection of dead tagged fish is that adequate numbers of dead fish had not been released to precisely quantify the dead-fish-detection probability (D). Based on releases of yearling dead fish in 2007, D would be 0.05 (1/20), but that very likely is inflated by the low number of dead fish released. If we assume that dead-fish detection probability is independent of fish age for all of 2007, then $D=0.025(1 / 40)$. If we pool all acoustically tagged dead fish released in 2006 and 2007 studies, D would be 0.017 (1/60), and there is reason to believe that $\underline{\mathrm{D}}$ may be even lower than 0.017 . Reprocessing spillway hydrophone data with the nextgeneration JSATS decoder delayed this report long enough that we can add dead fish release and detection data for 2008 to improve our estimate of D. In 2008, one dead fish was detected out of 99 released in spring and summer of what turned out to be a year of very high river discharge. Pooling all data from 2006, 2007, and 2008, there have been two dead-fish detections out of 159 releases $(\mathrm{D}=0.0126)$.

Previous radiotelemetry studies also detected dead fish on survival arrays below Bonneville Dam (Counihan et al. 2006a and 2006b), and, although detection rates for dead radio-tagged fish may differ from those of acoustically tagged fish, those detection probabilities are interesting. Counihan et al. (2006b) estimated a dead-fish-detection probability of 0.0206 for yearling Chinook salmon, and approximately 0.0103 for dead steelhead, and 0.0102 for dead subyearling Chinook salmon. The average of those estimates, assuming that the species of dead fish does not matter, was 0.014 , and this is within 1.4\% of our estimate based on all dead-fish releases and detections from 2006 through 2008.

One approach to handling the dead-fish-detection problem in 2004 (Counihan et al. 2006a) was to exclude data for fish with long egress times (> 99.7 percentile) from survival calculations. A second approach involved recalculating survival after removing release and detection data for all releases of fish that happened to have dead-fish detections (Counihan et al. 2006b). The latter approach assumes that conditions during some releases may increase the probability of detecting dead fish on survival arrays. These conditions could include river discharge and water temperature as well as population levels of scavengers (avian and fish) and time of day, which could affect the probability of birds or fish seeing and removing a body before it reached survival arrays.

According to Equations 3 and 4 in Appendix B, assuming D $=0.0126$, the average spring survival for yearling Chinook salmon would be $0.937[0.911 \leq \mathrm{S} \leq 0.964=0.95]$ instead of a weighted average of 0.957 for 2007 SC tags. Our weighted-mean estimate of survival for yearlings passing the spillway from 1600 to 1900 hours (0.957) was biased upward by about $2 \%$, because it did not account for $\mathrm{D}$. The paired-release, weighted-average survival for yearlings with 2007 SC tags (Table 3.10) only decreased by 0.01 , from $0.957(\mathrm{SE}=0.013)$ to $0.956(\mathrm{SE}=0.014)$, after we dropped the release that had the dead-fish detection (after Counihan et al. 2006b).

The choice of adjustment depends on how you view the mechanisms that result in dead-fish detections and how confident you are in the estimate of $\mathrm{D}$. We are not certain that dropping releases with dead-fish detections is enough. Releases of fish the day before or after a day that included a dead-fish detection likely would have had similar environmental conditions. In 2008, only one dead fish was detected out of 99 released in spite of very high river flows that should have greatly increased $\mathrm{D}$. This indicates that river discharge may not be the primary factor influencing the probability that a dead fish will float to the water's surface and then travel $>42 \mathrm{~km}$ downstream undetected by scavengers. The probability is so low that it appears to occur by chance alone and as such, probably should be corrected by using a cumulative estimate of D. 
To better quantify the rate of dead-fish detections for acoustic tags, we recommend releasing at least 50 dead fish each season during future survival studies conducted at Bonneville Dam. We arrived at this sample size based upon a preliminary dead-fish-detection probability of 0.0126 , and calculations provided to us by Drs. John Skalski and Rebecca Buchanan (see Appendix B). At about $\$ 185$ per tag, releasing 50 dead fish per season (100 total) would cost about $\$ 25,000$. To avoid sacrificing a lot of fish for future dead-fish releases, we recommend using dead specimens found before rigor mortis is obvious during routine smolt-monitoring operations as well as any fish that happen to die as a result of tagging (a common practice). Recently deceased fish also could be collected from the Bonneville Hatchery and refrigerated for 1 to 2 days until needed, although reasonable condition criteria would have to be established. If fish must be sacrificed, we recommend sacrificing individuals that would otherwise be rejected for tagging because of injury or descaling. These individuals would be much less likely to survive than healthy fish.

Since preliminary reporting on this study, several regional fish managers have expressed concern about moving survival arrays a lot further downstream from current locations and said that they preferred making corrections to survival estimates in the future. The managers worried about the survival effects of having a much longer tailwater and a loss of continuity with methods used in previous studies. Moving the first survival array $177 \mathrm{~km}$ downstream in 2007 would not have prevented the detection of the single dead tagged fish in 2007.

\subsection{Detection Performance of the Spillway Cabled Array}

The performance of acoustic receiving systems in the spillway forebay increased significantly after baffles were added to individual hydrophones, and development of a second-generation waveform decoder in spring 2008 decoded 1.7 times more tag signals than the original decoder available in 2007 (Figure 3.7). Star clusters of hydrophones were the only part of the cabled array deployed in time for the spring sampling season because of delays in receipt of equipment. We quickly discovered that very few released tags were being detected on star clusters, and we scrambled to deploy hydrophones on piers during the second week of study. The performance of pier hydrophones also was very poor until baffles were installed by the end of the third week to reduce noise coming from the direction of spill gates downstream of hydrophones. We did not baffle star clusters of hydrophones in the forebay because of safety issues related to retrieving and redeploying them (Figure 2.8) during spill. It also would not be desirable to baffle star clusters, because they are designed to detect and allow tracking of fish $360^{\circ}$ around the cluster. Another problem with star clusters was the narrow $22^{\circ}$ receiving angle of hydrophones, which were adapted from autonomous nodes. These narrow receiving angles function very well in autonomous nodes, because the highly sensitive hydrophones are constantly moving in the flow, whereas the hydrophones were in a fixed position when mounted on star clusters. Star clusters have great potential for out-of-baseline tracking of fish through areas with low background noise levels where hydrophone baffling is not required, and we recommend their continued development.

Tuning of detection software from late spring through summer and falling river discharge increased detection performance through the end of summer. The second version of the decoder software was significantly better than the first version at extracting acoustic tag codes from waveform data. By the end of summer 2007, the detector and second-generation decoder software were detecting and decoding about $80 \%$ of all acoustic tags released in the forebay. This would not have been possible without baffling individual hydrophones to reduce impulsive noise generated by vibrating spill-gates. 


\subsection{Detection Performance of Downstream Arrays}

Detection probabilities used for survival calculations were more than adequate to provide robust survival estimates for the entire spillway each season. We recorded no detection probabilities $<75 \%$ for single releases, and the average for the primary array was $92.7 \%$ in spring and $98.8 \%$ in summer. The average for the secondary array was $87.5 \%$ in spring and $96.6 \%$ in summer. Detection probabilities were higher in summer than in spring, because detection probabilities were inversely related to river discharge (Figure 3.10). River discharge determined the rate at which fish passed the autonomous hydrophone arrays. For example, the lowest detection probabilities were recorded around 20 May, when river discharge peaked in 2007. Given the relationship between detectability and river discharge, which is a surrogate for the rate at which fish pass through an array, we believe that it logically follows that tags with faster transmission rates would maintain high detection probabilities when river discharge peaks. Of course, the choice of tag transmission rate depends on study objectives. Based on improvements in JSATS acoustic tags in 2007 alone, pulse repetition rates can be cut in half and still provide for acceptable tag life for a study like this one. The 5-second ATS tags for JSATS in 2007 had a tag life of nearly 80 days (Figure 3.16), which was double that of 5-second tags used in 2006 (Ploskey et al. 2007b) and in spring 2007.

We examined the distribution of detections among autonomous nodes and the frequency of multiple detections of the same tag by different nodes within arrays to understand the detection performance of arrays. Cross-channel distributions indicated that most fish were traveling through main channel areas, but that detections outside the main channel could be significant and could not be ignored. For example the node north of Reed Island had $7 \%$ of secondary array detections in spring. Multiple detections of the same tag by different nodes within arrays provided a clear picture of why some arrays (e.g., the egress and primary arrays) performed much better than the others. Bottom morphology, including relatively shallow depths, sand bars, and islands in the secondary and tertiary arrays make acoustic detection more challenging. The best arrays, like the egress and the upper part of the primary array, were located at relatively deep constricted cross sections and had a lot of bottom scoured by flow to expose rock, which can reflect sound.

\subsection{Egress Rates}

Yearling and subyearling Chinook salmon passing through the spillway steadily egress to an array located $9 \mathrm{~km}$ downstream of the dam (Figures 3.11 and 3.12). For spring, travel times translated into rates of $1.6 \mathrm{~m} / \mathrm{s}$ for tailrace-released fish and 0.7 to $0.9 \mathrm{~m} / \mathrm{s}$ for spill-forebay released fish. Rates for spillway-passed fish are lower because of spillway-passage delays and the time it took to travel from the spillway to the tailrace release site $1.5 \mathrm{~km}$ downstream. For summer, travel times translated into average rates of $1.3 \mathrm{~m} / \mathrm{s}$ for tailrace-released fish and 0.6 to $0.8 \mathrm{~m} / \mathrm{s}$ for spillway-released fish. Again, rates for spillway-passed fish were depressed by average delays of 1.5 hours for spillway passage and travel to the tailrace-release site. The rates of movement of tailrace-released fish are similar to rates of river flow. We found that the mean travel time from the time of spillway passage to the egress array located $9 \mathrm{~km}$ downstream of the dam was 20 minutes longer $(\mathrm{P}=0.0105)$ for fish passing middle bays with shallow flow deflectors (2.58 hours) than it was for fish passing end bays with deep deflectors (2.26 hours).

The egress array was not part of the scope of work for 2007, nor did it have a counterpart array in previous years, so we compared average travel times from the tailrace release site to the primary array and 
from the primary to the secondary array in 2007 with those observed in 2006 (Table 4.1). Mean times were slightly slower in 2007 than in 2006, but this would be expected given that discharge was above the previous 10 -year average in spring and early summer in 2006, and it was similar to the 10 -year average in spring 2007 and below it in summer.

Table 4.1. Average Travel Times from Bonneville Tailrace to the Primary Array (BON1) and from the Primary to the Secondary Array (BON2) in 2006 and 2007. Values after the \pm signs are one-half of $95 \%$ confidence limits.

\begin{tabular}{cccc}
\hline Year / Season & Reach & Time (hours) & N \\
\hline 2006 / Spring & BON to BON1 & $7.8 \pm 0.7$ & 628 \\
2007 / Spring & BON to BON1 & $8.2 \pm 0.4$ & 887 \\
& & & 1,525 \\
2006 / Summer & BON to BON1 & $8.4 \pm 0.1$ & 1,002 \\
2007 / Summer & BON to BON1 & $9.1 \pm 0.3$ & 470 \\
& & & 764 \\
2006 / Spring & BON1 to BON2 & $1.4 \pm 0.3$ & \\
2007 / Spring & BON1 to BON2 & $3.1 \pm 0.4$ & 1,236 \\
2007 / Summer & BON1 to BON2 & $1.5 \pm 0.1$ & 964 \\
\hline
\end{tabular}

\subsection{Detection and Survival of Yearling Chinook Salmon in Spring}

Activities related to detection and survival of yearling Chinook salmon in spring involved the spring tag-life study, estimating the survival of spillway-passed yearlings, and comparison of deep-versus shallow flow deflector bays in spring, as discussed briefly in the following sections.

\subsubsection{Tag-Life Study}

The tag-life study verified that most tags lasted about as long as expected, although 1-year-old tags from 2006 lasted just $69 \%$ as long as 2007 tags from the same manufacturer. If tag life is marginal for a proposed study, the use of year-old tags could present a problem. The number of tags in the tag-life study should be standardized to 100 tags from each tag manufacturer and tag year so that the premature demise of a few tags does not have too much weight. There were only 292006 tags in this year's study, so each of those tags was worth about $3.5 \%$ of the total. Specifying single-year shelf-life criteria in tag procurements might allow manufacturers to reduce battery size and tag weight from what is required to meet a two-year shelf-life criterion. It also would assure that only fresh tags were used in survival studies. 


\subsubsection{Survival of Spillway-Passed Yearlings}

Our weighted-average estimate of survival of yearling Chinook salmon passing the spillway in spring, adjusted for dead-fish detection, had 95\% confidence limits that overlapped with those of six estimates from previous radiotelemetry studies (Table 4.2). Our estimates tended to be lower than previous estimates that included nighttime spill conditions, but that result would be expected because fish in the 2007 study were released during daylight hours.

Table 4.2. Survival Estimates from Previous Studies and this 2007 Study

\begin{tabular}{|c|c|c|c|c|c|c|}
\hline Species / Study & Condition & Study Year & Survival & $\begin{array}{l}\text { Lower } \\
95 \% \mathrm{CL}^{(\mathrm{a})}\end{array}$ & $\begin{array}{l}\text { Upper } \\
95 \% \mathrm{CL}^{(\mathrm{a})}\end{array}$ & $\begin{array}{l}\text { Over- } \\
\text { lap }^{(\mathrm{b})}\end{array}$ \\
\hline \multicolumn{7}{|c|}{ Yearling Chinook Salmon } \\
\hline $\begin{array}{l}\text { Counihan et al. } \\
2003\end{array}$ & $\begin{array}{l}\text { Spillway under all conditions; route } \\
\text { specific }\end{array}$ & 2002 & 0.977 & 0.951 & 1.004 & $=$ \\
\hline \multirow[t]{4}{*}{$\begin{array}{l}\text { Counihan et al. } \\
\text { 2006a }\end{array}$} & 56 kcfs daytime; route specific & 2004 & 0.891 & 0.840 & 0.936 & $=$ \\
\hline & 56 kcfs daytime; deep deflector bays & 2004 & 0.937 & 0.818 & 1.036 & $=$ \\
\hline & 56 kcfs daytime; shallow deflector bays & 2004 & 0.773 & 0.650 & 1.050 & $=$ \\
\hline & Ratio deep/shallow & 2004 & 1.212 & & & \\
\hline \multirow[t]{2}{*}{$\begin{array}{l}\text { Counihan et al. } \\
\text { 2006b }\end{array}$} & All conditions; route specific & 2005 & 0.930 & 0.912 & 0.947 & $=$ \\
\hline & 75 kcfs spill; & 2005 & 0.897 & 0.872 & 0.921 & $=$ \\
\hline \multirow[t]{2}{*}{ This study } & Daytime release; entire spillway & 2007 & $0.937^{(\mathrm{c})}$ & 0.911 & 0.964 & \\
\hline & $\begin{array}{l}\text { Ratio deep/shallow (ratio of single } \\
\text { releases) }\end{array}$ & 2007 & 0.969 & & & \\
\hline \multicolumn{7}{|c|}{ Subyearlings } \\
\hline \multirow[t]{2}{*}{$\begin{array}{l}\text { Counihan et al. } \\
\text { 2006a }\end{array}$} & $\begin{array}{l}56 \text { kcfs daytime \& gas cap night; deep } \\
\text { deflector bays }\end{array}$ & 2004 & 0.920 & 0.899 & 0.941 & $=$ \\
\hline & $\begin{array}{l}56 \text { kcfs daytime \& gas cap night; } \\
\text { shallow deflector bays }\end{array}$ & 2004 & 0.803 & 0.749 & 0.857 & $<$ \\
\hline \multirow[t]{2}{*}{$\begin{array}{l}\text { Counihan et al. } \\
\text { 2006b }\end{array}$} & All Conditions; entire spillway & 2005 & 0.911 & 0.893 & 0.929 & $=$ \\
\hline & 75 kcfs daytime; route specific & 2005 & 0.870 & 0.847 & 0.892 & $<$ \\
\hline \multirow[t]{2}{*}{ This study } & Daytime release; entire spillway & 2007 & 0.930 & 0.917 & 0.947 & \\
\hline & $\begin{array}{l}\text { Ratio deep/shallow (ratio of single } \\
\text { releases) }\end{array}$ & 2007 & 1.025 & 1.007 & 1.043 & \\
\hline
\end{tabular}

(a) $\mathrm{CL}=$ confidence limit.

(b) Overlap refers to overlapping 95\% CIs; Estimates followed by an equal symbol had 95\% CIs that overlapped with those of 2007 estimates, and estimates followed by a < symbol were less than 2007 estimates based on non-overlap of 95\% CIs.

(c) Adjustment for one dead-fish detection applied; 0.957 [0.931, 0.970; 95\% CL] without the adjustment.

\subsubsection{Comparison of Deep Versus Shallow Flow Deflector Bays in Spring}

We found no effect of spill-bay deflector type on survival in spring, because estimates were based on small numbers of tracked fish (167 yearlings tracked to middle bays and 114 tracked to end bays), poor 
precision $\left(0.849 \leq \mathrm{RS}_{1} \leq 1.089 ; 95 \% \mathrm{CI}\right)$, and inadequate statistical power. We recommend that the spring test be repeated because summer results clearly showed the benefits of baffling individual of hydrophones and tuning detection and decoding software (see Figure 3.7). Even though the spring test for 2007 lacked power to reject the null hypothesis, mean tailrace elevations that probably influence relative survival were about $1 \mathrm{~m}$ higher in spring 2007 (mean = 6.44 $\mathrm{m}$ above MSL; Figure 3.3) than they were in 2004 when Counihan et al. (2006a) found significant differences.

\subsection{Detection and Survival of Subyearling Chinook Salmon in Summer}

Activities related to the detection and survival of subyearling Chinook salmon during the summer involved the tag-life study, spillway-passed subyearlings, and comparison of the fish passage survivals of fish passing through spill bays containing deep and shallow flow deflectors as described briefly in the following sections

\subsubsection{Tag-Life Study}

All subyearlings passed survival arrays before there was a significant probability of tag failure so no tag-life adjustments were made in summer. Tag-life studies are a critical part of all survival studies that rely on active tags.

\subsubsection{Survival of Spillway-Passed Subyearlings}

Our weighted-average estimate of survival of subyearling Chinook salmon passing the spillway in summer was 0.930 and had $95 \%$ confidence limits that overlapped with those of two estimates from previous radiotelemetry studies and that were higher than estimates from two other studies (Table 4.2). Our paired-release estimates tended to be higher than previous estimates for subyearlings passing bays with shallow flow deflectors in 2004 and higher than daytime estimates under $75 \mathrm{kcfs}$ spill in 2005 . The 56 kcfs spill condition in summer 2004 and low tailrace elevations reduced survival estimates for fish passing bays with shallow spill deflectors. Higher subyearling survival under daytime spill in 2007 over rates observed in 2005 may be explained by differences in spill patterns between the 2 years. After 2005, spill consisted of 100,000-cfs spill for 24 hours/day in spring and a modified BiOp spill that provided larger gate openings in summer than had been used in prior years. Smaller gate openings used in 2005 likely increased mortality.

\subsubsection{Comparison of Deep Versus Shallow Flow Deflector Bays in Summer}

Statistical tests on 2007 data showed that deep flow deflector spill bays had 6.3\% higher passage survival in the first reach than shallow flow deflector spill bays, and this result was consistent with findings in summer 2004 by Counihan et al. (2006a). Conditions in summer 2004 were exacerbated by low spill discharge during the day (56,000 cfs compared to 80,000 cfs in 2007) and low tailrace elevations that averaged just $4.24 \mathrm{~m}$ above MSL. In contrast, mean tailrace elevations in summer 2007 were closer to $5.34 \mathrm{~m}$ above MSL (Figure 3.3). Low tailrace elevations and spill discharge in 2004 probably explain why the deep-to-shallow ratio of survival for subyearlings was much higher in 2004 than it was in 2007 (Table 4.2). Nevertheless, high precision associated with estimates in 2007 provided adequate power to 
reject the null hypothesis and support the alternative that survival of fish passing deep flow deflector bays was higher than that for fish passing bays with shallow flow deflectors.

The most likely environmental conditions reducing survival of subyearling Chinook salmon passing bays with shallow flow deflectors are below-average project discharge and low-tailrace elevations in summer. Below-average project discharge resulted in low tailwater elevations that were often within $1 \mathrm{~m}$ of shallow flow deflectors in summer. In contrast, project discharge was similar to the 10-year average in spring, and tailrace elevations were mostly in the range of 6.1 to $7.0 \mathrm{~m}$ above MSL. The lowest tailrace elevations observed for about 4 days in spring were at least $5.5 \mathrm{~m}$ above MSL, and we observed no significant difference in survival of fish passing bays with shallow and deep flow deflectors, although statistical power was poor in spring.

Mechanisms for increased mortality when tailrace elevations are within $1 \mathrm{~m}$ of shallow flow deflectors at middle bays are unknown, but we can speculate that the proximity of fish to deflector surfaces decreases as the amount of water passing over deflectors decreases. In the early 1970s, Johnson and Dawley (1974) found that fall Chinook salmon passing bays without flow deflectors had higher survival (95.8\%) than subyearlings passing bays with flow deflectors (86.8\%). Any injury or loss of equilibrium associated with abrasion or shear could increase susceptibility of fish to predation or disease so there could be immediate or delayed mortality. For subyearlings in summer, we found that the mean travel time to the egress array located $9 \mathrm{~km}$ downstream of the dam was 20 minutes longer $(\mathrm{P}=0.0105)$ for fish passing middle bays with shallow flow deflectors (2.58 hours) than it was for fish passing end bays with deep deflectors (2.26 hours). It is impossible to say whether the 20-minute delay for fish passing middle bays is related to flow deflectors or bay locations, but clearly a 20-minute delay increases the time that fish are exposed to predators.

We found a significant effect of passage through bays with shallow and deep flow deflectors on survival in the first reach between the dam and the primary array in summer 2007, but no effect on survival in the second reach between the primary and secondary array. Results suggest that most mortality associated with bay of passage was complete by the time fish arrived at the primary array. The first reach from the dam to the primary array $(24.8 \mathrm{~km})$ is 3.8 times longer than the second reach from the primary to the secondary array $(6.5 \mathrm{~km})$.

\subsection{Summary of 2007 Survival Results}

We found significantly higher survival for juvenile Chinook salmon passing bays with deep flow deflectors than for those passing bays with shallow flow deflectors in summer $(\mathrm{P}<0.001)$ but not in spring $(P=0.805)$. Spring estimates were plagued by low numbers of tracked fish that reduced precision and statistical power. Tailrace-elevation conditions that might have influenced relative survival among deflector bay types were clearly evident in summer but not in spring.

Finding similar rates of survival in spring and summer was a little surprising; we would have expected a larger downward trend during summer if not for our local release of treatment fish directly in the spillway forebay instead of in the tailrace of The Dalles Dam $72 \mathrm{~km}$ upstream. Spillway survival of 0.937 (corrected for a dead-fish detection) or 0.956 (uncorrected) for spring 2007 or 0.930 for summer were based on daytime releases. Therefore, it was not too surprising that those estimates tended to be lower than expected for fish passing the spillway at night when spill often is ramped up to the gas cap. 


\subsection{Tests of Survival-Model Assumptions}

Each release group (i.e., middle bay, end bay, pooled spillway, and tailrace) provides the data to estimate reach survival based on the single release-recapture model (Skalski et al. 1998). Assumptions of the single release-recapture model are as follows:

A1. Individuals marked for the study are a representative sample from the population of interest.

A2. Survival and capture probabilities are not affected by tagging or sampling. That is, tagged animals have the same detection and survival probabilities as untagged animals.

A3. All sampling events are "instantaneous." That is, sampling occurs over a negligible distance relative to the length of the intervals between sampling events.

A4. The fate of each tagged individual is independent of the fate of all others.

A5. All tagged individuals alive at a sampling location have the same probability of surviving until the end of that event.

A6. All tagged individuals alive at a sampling location have the same probability of being detected during that event.

A7. All tags are correctly identified and the status of smolts (i.e., alive or dead) is correctly assessed.

The first assumption (A1) concerns making inferences from the sampled population to the target population. For example, if inferences are sought to yearling Chinook salmon smolts, then the sample of tagged fish should be drawn from that class of fish. Otherwise, nonstatistical inferences are necessary, justifying the similarity between the target population and the representatives of acoustic-tagged fish. These assumptions also could be violated if smolts selected for tagging were, on the average, larger than the population of smolts in general. This certainly was true in summer 2007, because of limitations of the 95-mm minimum length of smolts that could be tagged but not in spring (see Figures 3.5 and 3.6). Until miniaturization of acoustic tags reaches a point where $75-\mathrm{mm}$ smolts can be tagged, the length bias in summer will remain. This also could be true if fish collected in the B2 JMF (8 to 15\% of all juvenile Chinook passing the dam) had different lengths or conditions than fish passing by non-JMF routes.

Assumption (A2) again relates to making inferences to the population of interest (i.e., untagged fish). If tagging has a detrimental effect on survival, then estimates of survival from the single-release model will tend to be negatively biased (i.e., underestimated). Tag effects have been observed for fish implanted with JSATS tags on the Snake River at least by the time they reached McNary Dam and points downstream (Richard Brown, Personal Communication, 2007), but there was no evidence of effects for lesser distances and times. Based on JSATS tag-effect studies conducted to date, we would expect only minor effects for fish tagged, released, and detected within 48 hours.

The third assumption (A3) specifies that mortality is negligible immediately in the vicinity of the sampling stations, so that the estimated mortality is related to the river reaches in question and not to the sampling event. In the case of acoustic-tagged outmigrating smolts, the time they spend in the vicinity of a hydrophone array is brief and narrow, relative to the size of the river reaches in question. This assumption should be fulfilled by the nature of the outmigration dynamics and deployment of hydrophone arrays. 
The assumption of independence (A4) implies that the survival or death of one smolt has no effect on the fates of others. In the larger river system with tens of thousands of smolts, this is likely true. Furthermore, this assumption is common to all tag analyses with little or no evidence collected to suggest that it is not generally true. Nevertheless, violations of assumption (A4) have little effect on the point estimate, but might bias the variance estimate with precision being less than calculated.

Assumption (A5) specifies that a smolt's prior detection history has no effect on subsequent survival. This could be violated if some smolts were self-trained to repeatedly go through turbine or spill routes or, alternatively, avoid routes because of prior experience. This occurrence is unlikely and can be assessed from the detection histories of the individual smolts. For acoustic-tagged smolts, the lack of handling following initial release further minimizes the risk that subsequent detections influence survival. Similarly, assumption (A6) could be violated if downstream detections were influenced by upstream passage routes taken by the smolts. This assumption is minimized by placing hydrophone arrays across the breadth of the river or below the mixing zones for smolts following different passage routes at the dam.

Assumption (A7) implies that the smolts do not lose their tags and are subsequently misidentified as dead or not captured, nor are dead fish falsely recorded as alive at detection locations. Tag loss or tag failure would tend to result in a negative bias (i.e., underestimation) of smolt survival. Tag failure will depend on travel times relative to battery life. Acoustic-tag survival rates are adjusted for tag failure rates using a separate tag-life study. Acoustically tagged dead fish drifting downstream could result in false-positive detections and upwardly bias survival estimates.

We adjusted spring estimates for yearlings bearing 2007 SC tags to adjust for tag-life effects, and we also adjusted those estimates for the detection of a single dead fish on May 25, 2007. There is a definite need to better estimate the probability of detecting dead fish on survival arrays, as discussed earlier in this section, and this can be done in future studies by releasing more dead fish implanted with acoustic transmitters.

To estimate survival components from the paired releases, two additional assumptions for valid survival estimates are necessary. These assumptions are as follows:

A8. Survival in the lower river reaches is conditionally independent of survival in the upper river reaches.

A9. Releases in the spillway and tailrace experience the same survival probabilities in the lower river reaches they share in common.

Assumption (A8) implies that there is no synergistic relationship between survival processes in the two river reaches. In other words, smolts that survive the first river reach are no more or less susceptible to mortality in the second river reach than smolts released in the second river reach. Assumption (A9) is satisfied by the in-river mixing of the release groups, but also can be satisfied if the survival processes are stable over the course of smolt passage by the releases. A stable survival process might well be expected for one to a few days under similar flow and spill conditions, which is exactly what occurred in this study. 
The valid estimation of Bonneville Dam spillway survivals using the paired-release detection data from the acoustic-tag studies depends upon the data conforming to model assumptions. These requirements include fulfilling the assumptions of the single-release-recapture model for each release and the paired-release-recapture model for each pair of releases.

For the single-release-recapture model to be valid, certain data patterns should be evident from the capture histories. For each release group, a series of tests of assumptions was performed to determine the validity of the model (i.e., goodness of fit). The data from a single release can be summarized by an m-array matrix of the form shown below:

\begin{tabular}{cccc}
\hline & \multicolumn{3}{c}{ Detection Site } \\
\cline { 2 - 4 } Release Site & BON1 (2) & BON2 (3) & BON3(4) \\
\hline Initial (1) & $m_{12}$ & $m_{13}$ & $m_{14}$ \\
BON1 (2) & & $m_{23}$ & $m_{24}$ \\
BON2 (3) & & $m_{34}$ \\
\hline
\end{tabular}

The value of $m_{i j}$ is the number of smolts detected at site $i$ that are next detected at site $j$. There were several instances where detection history data were not homogeneous and we had to rely on weighted-average estimates instead of pooling data over a season. In general, we were conservative and used weighted-average estimates whenever a Chi-square test of significant at $\alpha=0.10$.

Burnham et al. (1987; p. 65, pp.71-74) also present a series of tests of assumptions called Test 2, which examine whether upstream detections affect downstream survival and/or detection. For each release, a contingency table test can be performed, as follows:

Test 2.2

\begin{tabular}{|l|l|}
\hline$m_{13}$ & $m_{14}$ \\
\hline$m_{23}$ & $m_{24}$ \\
\hline
\end{tabular}

Tests were performed at $\alpha=0.10$. 
Burnham et al. (1987; p. 65, pp.74-77) also present a series of tests of assumptions called Test 3, which examines whether upstream capture histories affect downstream survival and/or capture. For each release, a contingency table of the following form was constructed:

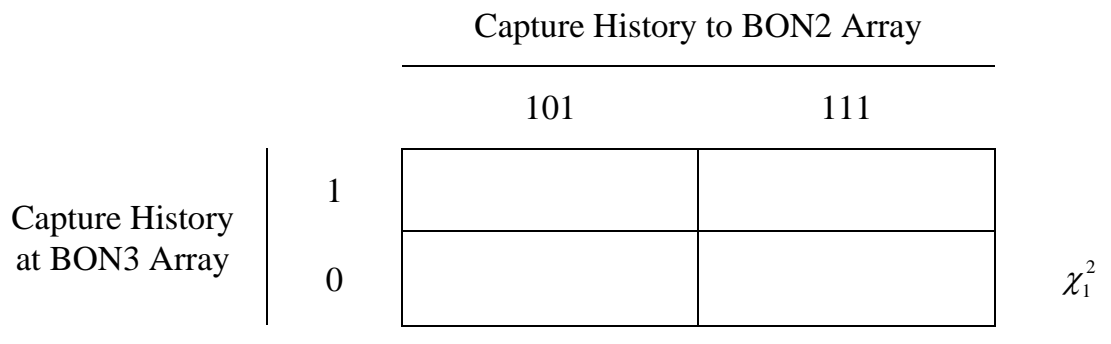

This contingency table tested whether detection at the BON2 array has a subsequent effect on the detection history at the BON3 array.

Arrival distributions at each acoustic array were tested for homogeneity using an $\mathrm{R} x \mathrm{C}$ contingency table of the following form:

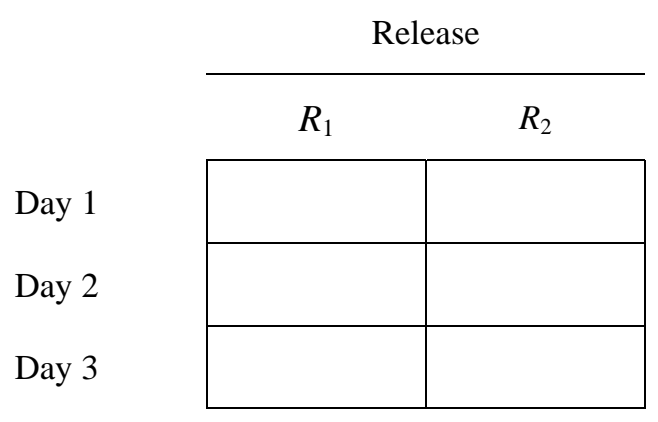

The purpose of this test was to determine whether releases were timed so that each release group would be traveling through the same area at the same time to more closely match influences on survival of the two groups being compared (i.e., middle bay versus end bay, spillway versus tailrace).

\subsubsection{Burnham Test Results}

For the most part, the Burnham tests indicated that study assumptions were not violated. A number of spring Chinook salmon release groups using the 2007 SC acoustic tag rejected the Burnham 2.2 (5 out of 30 testable groups) and 3.1 (8 out of 36 testable groups) tests (Table 3.31), indicating that the null hypothesis that upstream detection did not affect downstream survival may not be true. Although it is unlikely that the act of detection affected the downstream survival of these fish, a violation may indicate that either the tag life of the acoustic tag had a larger effect on survival than the tag-life test would suggest, or the fish detected upriver were more likely to travel through a part of the river that had greater affect on their survival than those fish not detected at the same array. These possible explanations for violations of assumptions are only reasonable if the explanations are plausible. We have no evidence of a greater tag effect than the minor one we observed or that survival mechanisms differ between arrays. It could be that the arrays are not far enough apart to be completely independent, although it is true fish that cannot be simultaneously detected on any of the survival arrays below Bonneville Dam because they are 
too far apart. Counihan et al. (2002) noted that the utility of these tests seemed to be affected by high capture probabilities at radiotelemetry arrays, and if true, that would also be the case for tests on pooled data in this study. High detection rates and lack of a mechanism for model violations appear to make the violations artifacts of previous technologies.

A large number of tests could not be conducted, especially on the summer Chinook salmon data because of the high detection rates observed at BON1 and BON2 acoustic arrays. Burnham tests use the fish that pass a site undetected as a virtual release and compare their common downriver survival to those that were detected at that site. At high detection rates, this removes the "comparison" group and renders the test meaningless. A double-whammy occurs in studies with acoustic tags, because there are fewer fish in the study to begin with, thereby increasing the possibility that there will be no virtual release group to test against.

\subsubsection{Mixing of Spillway- and Tailrace-Released Fish}

Visual inspection of Figures 3.21 through Figure 3.24 is adequate to discern that arrival distributions of treatment and reference releases within 4-hour blocks had means that did not differ significantly. Nevertheless, the majority of the chi-square tests performed on arrival times within 4-hour blocks resulted in $P$-values less than 0.10 ( 4 of 6 for the spring Chinook - Figures 3.21 and 3.22; 6 of 6 for the summer Chinook salmon - Figures 3.23 and 3.24). Chi-square tests are very unreliable when a number of cells have counts with less than five observations, as is the case in all of these comparisons.

Comparing standardized hours of arrival relative to midnight (i.e., before, at, or after midnight) clearly indicated that the mean hour of arrival at the primary array did not differ significantly for releases in the forebay and tailrace each season (Figure 1.1). On average, tailrace fish arrived $\leq 1$ hour earlier than forebay fish during each paired release in 2007 and standard errors ranged from 1 to 3 hours. 


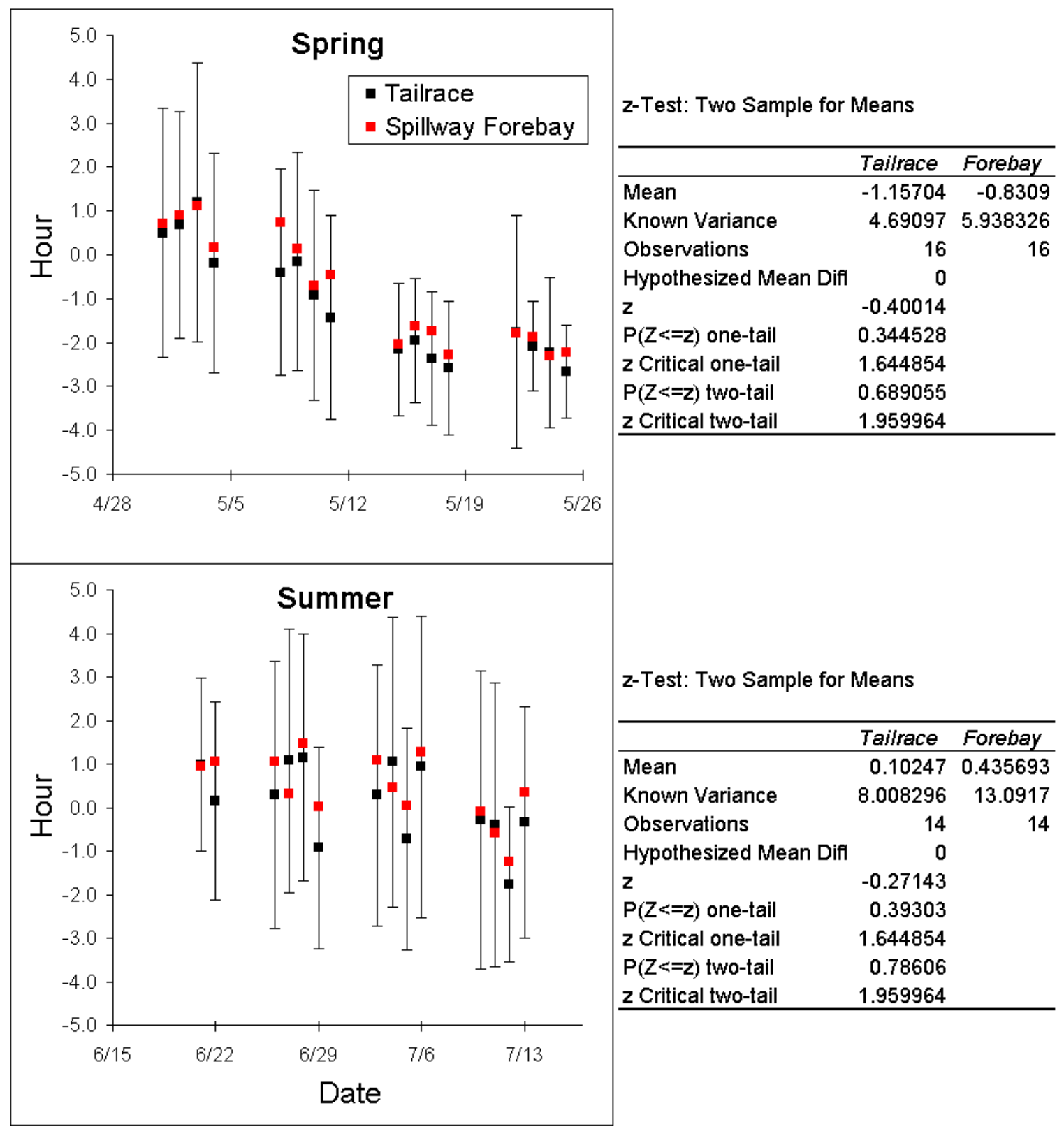

Figure 4.1. Plot of Hour of Arrival Before, at, or After Midnight at Array BON1 for Fish Released in the Spillway Forebay and Tailrace in Spring and Summer 2007. Vertical bars are standard errors for the tailrace release groups. Tables to the right of each plot present z-tests for two-sample means indicating that means did not differ significantly either season. 



\subsection{Recommendations}

The following recommendations are derived from the study results:

1. To better quantify the probability of detecting dead fish on survival arrays below Bonneville Dam, we recommend releasing at least 50 dead fish each season during the next survival study at this dam. A low incidence of detection of dead tagged fish has been observed in two radiotelemetry studies and this acoustic-telemetry study, and although the probability appears to be low ( $\underline{D} \leq 0.017$ ), studies to date have not released enough dead tagged fish to accurately quantify the rate. Detection of dead tagged fish implanted with tags results in a positive bias in estimates of survival that can be corrected if researchers have precise estimates of $\underline{D}$.

2. To avoid sacrificing a lot of fish for future dead-fish releases, we recommend using dead specimens found before rigor mortis is obvious during routine smolt-monitoring operations as well as any fish that happen to die as a result of tagging. Recently deceased fish also could be collected from the Bonneville Hatchery and refrigerated for 1 to 2 days until needed, although reasonable condition criteria would have to be established. If fish must be sacrificed, we recommend sacrificing individuals that would otherwise be rejected for tagging because of injury or descaling. These individuals would be much less likely to survive than healthy fish.

3. We recommend continued experimentation with hydrophone baffling to identify the most effective materials and configurations. By the end of summer 2007, the detector and second-generation decoder software were detecting and decoding about $80 \%$ of all acoustic tags released in the forebay. This would not have been possible without baffling individual hydrophones to reduce noise originating from sources other than acoustic tags.

4. Star clusters have great potential for out-of-baseline tracking of fish through areas with low background noise levels where hydrophone baffling is not required, and we recommend continued development of these systems.

5. We recommend repeating the spring test comparing the survival of yearling Chinook salmon passing through spill bays that contain deep and shallow flow deflectors. The spring test in 2007 had insufficient numbers of yearlings tracked to specific bays to provide the statistical power required to reject the null hypothesis that the ratio of survivals for fish passing deep and shallow deflector bays was not $>1$. The tracking deficiency was rectified by the last week of spring and for summer by baffling individual hydrophones installed on piers and tuning the detection and decoder software. The test must be repeated to provide a robust assessment of effects in spring. Sample sizes must be large to deliver the required statistical power, because suspect causal mechanisms (i.e., low discharge and low tailrace pool elevations) are less common in spring than they are in summer. 



\subsection{References}

Adams, N.S., R.E. Reagan, S.D. Evans, M.J. Farley, L.S. Wright, and D.W. Rondorf. 2006. Movement, Distribution, and Passage Behavior of Radio-Tagged Juvenile Chinook Salmon and Steelhead at Bonneville Dam, 2005. Draft Annual Report by the U.S. Geological Survey, Columbia River Research Laboratory, Cook, Washington for the U.S. Army Engineer District, Portland, Oregon.

Brett, J.R. 1952. “Temperature Tolerance in Young Pacific Salmon, Genus Oncorhynchus.” Journal of the Fisheries Research Board of Canada 9:265-323.

Burnham, K.P., D.R Anderson, G.C. White, C. Brownie, and K.H. Pollock. 1987. "Design and analysis methods for fish survival estimates based on release-recapture.” American Fisheries Society Monograph No. 5.

Cobleigh, M.M. 2003. Stress, Growth and Survival of Juvenile Chinook Salmon. MS Thesis, University of Washington, Seattle, Washington.

Cormack, R.M. 1964. Estimates of survival from the sightings of marked animals. Biometrika 51:429-438.

Counihan, T.D., J.H. Petersen, and K.J. Felton. 2002. Survival Estimates of Migrant Juvenile Salmonids in the Columbia River from John Day Dam through Bonneville Dam using Radio-Telemetry, 2000. Annual report prepared by the U.S. Geological Survey, Cook, Washington, for the U.S. Army Corps of Engineers, Portland, Oregon.

Counihan, T.D., A.L. Puls, C.E. Walker, J.M. Hardiman, and G.S. Holmberg. 2006a. Survival Estimates of Migrant Juvenile Salmonids through The Dalles Dam Using Radiotelemetry, 2004. Final Report of Research prepared by the U.S. Geological Survey, Cook, Washington, for the U.S. Army Corps of Engineers, Portland, Oregon.

Counihan, T.D., A.L. Puls, C.E. Walker, J.M. Hardiman, and G.S. Holmberg. 2006b. Survival Estimates of Migrant Juvenile Salmonids through The Dalles Dam Using Radiotelemetry, 2005. Final Report of Research prepared by the U.S. Geological Survey, Cook, Washington, for the U.S. Army Corps of Engineers, Portland, Oregon.

Efron, B., and R. J. Tibshirani. 1993. An Introduction to the Bootstrap. Chapman \& Hall, New York.

Evans, S., L. Wright, R. Reagan, N. Adams, and D. Rondorf. 2006. Passage Behavior of Radio-Tagged Subyearling Chinook Salmon at Bonneville Dam, 2004: Revised for Corrected Spill. Annual Report by the U.S. Geological Survey, Columbia River Research Laboratory, Cook, Washington for the U.S. Army Engineer District, Portland, Oregon.

Jolly, G.M. 1965. "Explicit estimates from capture-recapture data with both death and immigration stochastic model.” Biometrika 52:225-247.

Johnson, R.C., and E.M. Dawley. 1974. The Effect of Spillway Flow Deflectors at Bonneville Dam on Total Gas Supersaturation and Survival of Juvenile Salmon. Report to U.S. Army Corps of Engineers, Contract DACW-57-74-F-0122. (Available from the Northwest Fisheries Science Center, 2725 Montlake Blvd. E., Seattle, WA 98112-2097.) 
Martinson, R., G. Kovalchuk, and D. Ballinger. 2006. Monitoring of Downstream Salmon and Steelhead at Federal Hydroelectric Facilities, 2005-2006 Annual Report. Project No. 198712700, BPA Report DOE/BP-00022085-2, Bonneville Power Administration, Portland, Oregon.

McCullagh, P. and J.A. Nelder. 1989. Generalized Linear Models (2nd Edition). Chapman and Hall: London. pp 35-36.

Normandeau Associates Inc., J.R. Skalski, and Mid Columbia Consulting Inc. 1996. Potential Effects of Spillway Flow Deflectors on Fish Condition and Survival at the Bonneville Dam, Columbia River. Prepared for the U.S. Army Corps of Engineers - Portland District by Normandeau Associated Inc., Drumore, Pennsylvania.

Normandeau Associates Inc., Mid Columbia Consulting Inc., and J.R. Skalski. 2003. Juvenile Salmonid Survival and Condition in Passage through Modified Spillbays at Bonneville Dam, Columbia River. Prepared for U.S. Army Corps of Engineers, Portland District, Portland, Oregon, by Normandeau Associated Inc., Drumore, Pennsylvania.

Peven, C., A. Giorgi, J.R. Skalski, M. Langeslay, A. Grassell, S.G. Smith, T. Counihan, R. Perry, and S. Bickford. 2005. Guidelines and Recommended Protocols for Conducting, Analyzing, and Reporting Juvenile Salmonid Survival Studies in the Columbia River Basin. Published electronically; available in PDF electronic format from chuckp@chelanpud.org.

Ploskey, G.R., G.E. Johnson, A.E. Giorgi, R.L. Johnson, J.R. Stevenson, C.R. Schilt, P.N. Johnson, and D.S. Patterson. 2007a. Synthesis of Biological Reports on Juvenile Fish Passage and Survival at Bonneville Dam, 1939-2005. PNNL-15041, Pacific Northwest National Laboratory, Richland, Washington.

Ploskey, G.R., M.A. Weiland, J.S. Hughes, S.A. Zimmerman, R.E. Durham, E.S. Fischer, J. Kim, R.L. Townsend, J.R. Skalski, and R.L. McComas. 2007b. Acoustic Telemetry Studies of Juvenile Chinook Salmon Survival at the Lower Columbia Projects in 2006. PNNL-16560, Pacific Northwest National Laboratory, Richland, Washington.

Reagan, R., S. Evans, L. Wright, M. Farley, N. Adams, and D. Rondorf. 2006. Passage Behavior of Radio-Tagged Yearling Chinook Salmon and Steelhead at Bonneville Dam, 2004 (revised for corrected spill). Annual Report by the U.S. Geological Survey, Columbia River Research Laboratory, Cook, Washington for the U.S. Army Engineer District, Portland, Oregon.

Seber, G. A. F. 1965. A note on the multiple recapture census. Biometrika 52:249-259.

Schneider, M. L., J. Carroll, C. C. Schneider, and K. Barko. 2003. Total Dissolved Gas Exchange at Bonneville Dam, 2002 Spill Season. Technical Report by the U. S. Army Engineer Research and Development Center for the U. S. Army Engineer District, Portland, USA.

Skalski, J.R., S.G. Smith, R.N. Iwamoto, J.G. Williams, and A. Hoffmann. 1998. "Use of PIT-tags to estimate survival of migrating juvenile salmonids in the Snake and Columbia Rivers.” Canadian Journal of Fisheries and Aquatic Sciences 55:1484-1493.

Tiffan, K.F., D.W. Rondorf, and P.G. Wagner. 2000. “Physiological development and migratory behavior of subyearling chinook salmon in the Columbia river.” North American Journal of Fisheries Management 20:28-40. 
Townsend, R.L., J.R. Skalski, P. Dillingham, and T.W. Steig. 2006. "Correcting bias in survival estimation resulting from tag failure in acoustic and radiotelemetry studies.” Journal of Agricultural Biology and Environmental Statistics (in press).

Zabel, R.W., T.W. Wagner, J.L. Congleton, S.C. Smith, and L.C. Williams. 2005. Survival and selection of migrating salmon from capture-recapture models with individual traits. Ecological Applications 15(4):1427-1439. 

Appendix A

\section{Tables of All Fish Tagging and Release Data}





\section{Appendix A}

\section{Tables of All Fish Tagging and Release Data}

Table A.1. Summary of Tagging Numbers and Statistics by Release Location, and Release Date in Spring

\begin{tabular}{|c|c|c|c|c|c|c|c|c|}
\hline Release Location & $\begin{array}{l}\text { Release } \\
\text { Date }\end{array}$ & $\begin{array}{l}\text { Number } \\
\text { Released }\end{array}$ & $\begin{array}{c}\text { Number } \\
\text { Surviving } \\
\text { Tagging }\end{array}$ & $\begin{array}{c}\text { Percent } \\
\text { Alive }\end{array}$ & $\begin{array}{l}\text { Number } \\
\text { Dying }\end{array}$ & $\begin{array}{c}\text { Percent } \\
\text { Dying }\end{array}$ & $\begin{array}{l}\text { Number } \\
\text { Sacrificed }\end{array}$ & $\begin{array}{c}\text { Percent } \\
\text { Sacrificed }\end{array}$ \\
\hline BON Tailrace & 05/01/2007 & 65 & 65 & 100.0 & 0 & 0.0 & 0 & 0 \\
\hline BON Tailrace & 05/02/2007 & 65 & 65 & 100.0 & 0 & 0.0 & 0 & 0 \\
\hline BON Tailrace & 05/03/2007 & 64 & 64 & 100.0 & 0 & 0.0 & 0 & 0 \\
\hline BON Tailrace & 05/04/2007 & 65 & 65 & 100.0 & 0 & 0.0 & 0 & 0 \\
\hline BON Tailrace & 05/08/2007 & 65 & 64 & 98.5 & 1 & 1.5 & 0 & 0 \\
\hline BON Tailrace & 05/09/2007 & 65 & 65 & 100.0 & 0 & 0.0 & 0 & 0 \\
\hline BON Tailrace & 05/10/2007 & 65 & 64 & 98.5 & 1 & 1.5 & 0 & 0 \\
\hline BON Tailrace & 05/11/2007 & 65 & 64 & 98.5 & 1 & 1.5 & 0 & 0 \\
\hline BON Tailrace & 05/15/2007 & 65 & 65 & 100.0 & 0 & 0.0 & 0 & 0 \\
\hline BON Tailrace & 05/16/2007 & 65 & 65 & 100.0 & 0 & 0.0 & 0 & 0 \\
\hline BON Tailrace & 05/17/2007 & 65 & 65 & 100.0 & 0 & 0.0 & 0 & 0 \\
\hline BON Tailrace & 05/18/2007 & 65 & 65 & 100.0 & 0 & 0.0 & 0 & 0 \\
\hline BON Tailrace & 05/19/2007 & 250 & 250 & 100.0 & 0 & 0.0 & 0 & 0 \\
\hline BON Tailrace & $05 / 23 / 2007$ & 65 & 65 & 100.0 & 0 & 0.0 & 0 & 0 \\
\hline BON Tailrace & 05/24/2007 & 65 & 65 & 100.0 & 0 & 0.0 & 0 & 0 \\
\hline BON Tailrace & $05 / 25 / 2007$ & 65 & 65 & 100.0 & 0 & 0.0 & 0 & 0 \\
\hline $\begin{array}{l}\text { BON Tailrace } \\
\text { Summary }\end{array}$ & All & 1,224 & 1221 & 99.8 & 3 & 0.2 & 0 & 0 \\
\hline
\end{tabular}


Table A.1. (contd)

\begin{tabular}{|c|c|c|c|c|c|c|c|c|}
\hline Release Location & $\begin{array}{l}\text { Release } \\
\text { Date }\end{array}$ & $\begin{array}{l}\text { Number } \\
\text { Released }\end{array}$ & $\begin{array}{l}\text { Number } \\
\text { Surviving } \\
\text { Tagging }\end{array}$ & $\begin{array}{l}\text { Percent } \\
\text { Alive }\end{array}$ & $\begin{array}{l}\text { Number } \\
\text { Dying }\end{array}$ & $\begin{array}{c}\text { Percent } \\
\text { Dying }\end{array}$ & $\begin{array}{l}\text { Number } \\
\text { Sacrificed }\end{array}$ & $\begin{array}{c}\text { Percent } \\
\text { Sacrificed }\end{array}$ \\
\hline Spillway Forebay & 05/01/2007 & 187 & 185 & 98.9 & 2 & 1.1 & 0 & 0 \\
\hline Spillway Forebay & 05/02/2007 & 186 & 186 & 100.0 & 0 & 0.0 & 0 & 0 \\
\hline Spillway Forebay & 05/03/2007 & 187 & 187 & 100.0 & 0 & 0.0 & 0 & 0 \\
\hline Spillway Forebay & 05/04/2007 & 187 & 185 & 98.9 & 2 & 1.1 & 0 & 0 \\
\hline Spillway Forebay & 05/08/2007 & 187 & 185 & 98.9 & 2 & 1.1 & 0 & 0 \\
\hline Spillway Forebay & 05/09/2007 & 187 & 187 & 100.0 & 0 & 0.0 & 0 & 0 \\
\hline Spillway Forebay & 05/10/2007 & 187 & 187 & 100.0 & 0 & 0.0 & 0 & 0 \\
\hline Spillway Forebay & 05/11/2007 & 187 & 187 & 100.0 & 0 & 0.0 & 0 & 0 \\
\hline Spillway Forebay & $05 / 15 / 2007$ & 189 & 189 & 100.0 & 0 & 0.0 & 0 & 0 \\
\hline Spillway Forebay & 05/16/2007 & 187 & 187 & 100.0 & 0 & 0.0 & 0 & 0 \\
\hline Spillway Forebay & 05/17/2007 & 188 & 187 & 99.5 & 1 & 0.5 & 0 & 0 \\
\hline Spillway Forebay & 05/18/2007 & 188 & 188 & 100.0 & 0 & 0.0 & 0 & 0 \\
\hline Spillway Forebay & $05 / 22 / 2007$ & 188 & 188 & 100.0 & 0 & 0.0 & 0 & 0 \\
\hline Spillway Forebay & $05 / 23 / 2007$ & 188 & 188 & 100.0 & 0 & 0.0 & 0 & 0 \\
\hline Spillway Forebay & $05 / 24 / 2007$ & 188 & 188 & 100.0 & 0 & 0.0 & 0 & 0 \\
\hline Spillway Forebay & $05 / 25 / 2007$ & 188 & 178 & 94.7 & 0 & 0.0 & 10 & 5.3 \\
\hline $\begin{array}{l}\text { Spillway Forebay } \\
\text { Summary }\end{array}$ & All & 2999 & 2982 & 99.4 & 7 & 0.2 & 10 & 0 \\
\hline Grand Summary & All & 4223 & 4203 & 99.5 & 10 & 0.2 & 10 & 0 \\
\hline
\end{tabular}


Table A.2. Summary of Tagging Numbers and Statistics by Release Location, and Release Date in Summer

\begin{tabular}{|c|c|c|c|c|c|c|c|c|}
\hline Release Location & $\begin{array}{l}\text { Release } \\
\text { Date }\end{array}$ & $\begin{array}{l}\text { Number } \\
\text { Released }\end{array}$ & $\begin{array}{l}\text { Number } \\
\text { Surviving } \\
\text { Tagging }\end{array}$ & $\begin{array}{l}\text { Percent } \\
\text { Alive }\end{array}$ & $\begin{array}{l}\text { Number } \\
\text { Dying }\end{array}$ & $\begin{array}{c}\text { Percent } \\
\text { Dying }\end{array}$ & $\begin{array}{l}\text { Number } \\
\text { Sacrificed }\end{array}$ & $\begin{array}{c}\text { Percent } \\
\text { Sacrificed }\end{array}$ \\
\hline BON Tailrace & $06 / 21 / 2007$ & 74 & 74 & 100 & 0 & 0 & 0 & 0 \\
\hline BON Tailrace & $06 / 22 / 2007$ & 74 & 74 & 100 & 0 & 0 & 0 & 0 \\
\hline BON Tailrace & 06/26/2007 & 74 & 74 & 100 & 0 & 0 & 0 & 0 \\
\hline BON Tailrace & 06/27/2007 & 75 & 75 & 100 & 0 & 0 & 0 & 0 \\
\hline BON Tailrace & 06/28/2007 & 74 & 74 & 100 & 0 & 0 & 0 & 0 \\
\hline BON Tailrace & 06/29/2007 & 74 & 73 & 98.6 & 1 & 1.4 & 0 & 0 \\
\hline BON Tailrace & $07 / 03 / 2007$ & 74 & 74 & 100 & 0 & 0 & 0 & 0 \\
\hline BON Tailrace & $07 / 04 / 2007$ & 74 & 74 & 100 & 0 & 0 & 0 & 0 \\
\hline BON Tailrace & $07 / 05 / 2007$ & 74 & 74 & 100 & 0 & 0 & 0 & 0 \\
\hline BON Tailrace & 07/06/2007 & 74 & 74 & 100 & 0 & 0 & 0 & 0 \\
\hline BON Tailrace & 07/10/2007 & 75 & 75 & 100 & 0 & 0 & 0 & 0 \\
\hline BON Tailrace & 07/11/2007 & 70 & 69 & 98.6 & 1 & 1.4 & 0 & 0 \\
\hline BON Tailrace & 07/12/2007 & 80 & 80 & 100 & 0 & 0 & 0 & 0 \\
\hline BON Tailrace & 07/13/2007 & 75 & 75 & 100 & 0 & 0 & 0 & 0 \\
\hline $\begin{array}{l}\text { BON Tailrace } \\
\text { Summary }\end{array}$ & All & 1,041 & 1039 & 99.8 & 2 & 0.2 & 0 & 0 \\
\hline Spillway Forebay & 06/21/2007 & 215 & 215 & 100 & 0 & 0 & 0 & 0 \\
\hline Spillway Forebay & $06 / 22 / 2007$ & 215 & 214 & 99.5 & 1 & 0.5 & 0 & 0 \\
\hline Spillway Forebay & 06/26/2007 & 215 & 213 & 99.1 & 2 & 0.9 & 0 & 0 \\
\hline Spillway Forebay & 06/27/2007 & 214 & 213 & 99.5 & 1 & 0.5 & 0 & 0 \\
\hline Spillway Forebay & 06/28/2007 & 214 & 214 & 100 & 0 & 0 & 0 & 0 \\
\hline Spillway Forebay & 06/29/2007 & 215 & 214 & 99.5 & 1 & 0.5 & 0 & 0 \\
\hline Spillway Forebay & 07/03/2007 & 214 & 214 & 100 & 0 & 0 & 0 & 0 \\
\hline Spillway Forebay & $07 / 04 / 2007$ & 214 & 214 & 100 & 0 & 0 & 0 & 0 \\
\hline Spillway Forebay & 07/05/2007 & 214 & 214 & 100 & 0 & 0 & 0 & 0 \\
\hline Spillway Forebay & 07/06/2007 & 214 & 214 & 100 & 0 & 0 & 0 & 0 \\
\hline Spillway Forebay & 07/10/2007 & 214 & 213 & 99.5 & 1 & 0.5 & 0 & 0 \\
\hline Spillway Forebay & 07/11/2007 & 214 & 212 & 99.1 & 2 & 0.9 & 0 & 0 \\
\hline Spillway Forebay & $07 / 12 / 2007$ & 213 & 211 & 99.1 & 2 & 0.9 & 0 & 0 \\
\hline Spillway Forebay & 07/13/2007 & 214 & 206 & 96.3 & 2 & 0.9 & 6 & 2.8 \\
\hline $\begin{array}{c}\text { Spillway Forebay } \\
\text { Summary }\end{array}$ & All & 2,999 & 2981 & 99.4 & 12 & 0.4 & 6 & 0 \\
\hline Grand Summary & All & 4,040 & 4020 & 99.5 & 14 & 0.3 & 6 & 0 \\
\hline
\end{tabular}


Table A.3. List of Appendix A CSV Files on an Accompanying Compact Disc.* Variables in the CSV files are defined in Table A.5 below.

\begin{tabular}{ll}
\hline \multicolumn{1}{c}{ File } & \multicolumn{1}{c}{ Description } \\
\hline $\begin{array}{l}\text { Appendix A - Spring } \\
\text { Codes.CSV }\end{array}$ & PIT and Acoustic Tag Codes Released in Spring 2006 by Date, Time, and \\
Location followed by dam operations data \\
\begin{tabular}{ll} 
Appendix A - Summer & PIT and Acoustic Tag Codes Released in Summer 2006 by Date, Time and \\
Codes.CSV & Location followed by dam operations data \\
\hline * A compact disc accompanying the report has two files: Appendix A - Spring Codes.CSV and Appendix A - Summer \\
Codes.CSV.
\end{tabular} \\
\hline
\end{tabular}

Table A.4. Definitions of Variables in Headings of Appendix A CSV files on the Accompanying Compact Disc. Original units of elevation (ft) and discharge (cfs x 1,000) were retained in this appendix.

\begin{tabular}{ll}
\hline \multicolumn{1}{c}{ Variable } & \multicolumn{1}{c}{ Definition } \\
\hline SEASON & Fish Released season Spring/Summer \\
ReleaseDate & Fish released date \\
ReleaseTime & Fish released time \\
TagCode & PIT tag code \\
AcousticTagCode & Acoustic Tag Code \\
ActivationDate & Acoustic Tag Activated date \\
ForkLength & Fish length \\
Weight & Fish weight \\
Mortality & MORT/NO MORT \\
ReleaseLoc & Fish Release Location \\
FB & Forebay Elevation, ft above mean sea level \\
TW & Tailwater Elevation, ft above mean sea level \\
N_Units & Number of operating turbines \\
PH1_Q & Powerhouse 1 Discharge (cfs x 1000) \\
PH2_Q & Powerhouse 2 Discharge (cfs x 1000) \\
Spill_Q & Spillway Discharge (cfs x 1000) \\
Total_Q & Total Project Discharge (cfs x 1000) \\
T1 & Turbine 1 Discharge (cfs x 1000) \\
T2 & Turbine 2 Discharge (cfs x 1000) \\
T3 & Turbine 3 Discharge (cfs x 1000) \\
T4 & Turbine 4 Discharge (cfs x 1000) \\
T5 & Turbine 5 Discharge (cfs x 1000) \\
T6 & Turbine 6 Discharge (cfs x 1000) \\
T7 & Turbine 7 Discharge (cfs x 1000) \\
T8 & Turbine 8 Discharge (cfs x 1000) \\
\hline & Turbine 9 Discharge (cfs x 1000) \\
\hline
\end{tabular}


Table A.4. (contd)

\begin{tabular}{|c|c|}
\hline Variable & Definition \\
\hline $\mathrm{T} 10$ & Turbine 10 Discharge (cfs x 1000) \\
\hline $\mathrm{T} 11$ & Turbine 11 Discharge (cfs x 1000) \\
\hline $\mathrm{T} 12$ & Turbine 12 Discharge (cfs x 1000) \\
\hline $\mathrm{T} 13$ & Turbine 13 Discharge (cfs x 1000) \\
\hline $\mathrm{T} 14$ & Turbine 14 Discharge (cfs x 1000) \\
\hline $\mathrm{T} 15$ & Turbine 15 Discharge (cfs x 1000) \\
\hline $\mathrm{T} 16$ & Turbine 16 Discharge (cfs x 1000) \\
\hline $\mathrm{T} 17$ & Turbine 17 Discharge (cfs x 1000) \\
\hline $\mathrm{T} 18$ & Turbine 18 Discharge (cfs x 1000) \\
\hline T19 & Turbine 19 Discharge (cfs x 1000) \\
\hline $\mathrm{T} 20$ & Turbine 20 Discharge (cfs x 1000) \\
\hline $\mathrm{T} 21$ & Turbine 21 Discharge (cfs x 1000) \\
\hline $\mathrm{T} 22$ & Turbine 22 Discharge (cfs x 1000) \\
\hline S1 & Spill Bay 1 \\
\hline $\mathrm{S} 2$ & Spill Bay 2 \\
\hline S3 & Spill Bay 3 \\
\hline S4 & Spill Bay 4 \\
\hline S5 & Spill Bay 5 \\
\hline S6 & Spill Bay 6 \\
\hline S7 & Spill Bay 7 \\
\hline S8 & Spill Bay 8 \\
\hline S9 & Spill Bay 9 \\
\hline S10 & Spill Bay 10 \\
\hline S11 & Spill Bay 11 \\
\hline S12 & Spill Bay 12 \\
\hline S13 & Spill Bay 13 \\
\hline S14 & Spill Bay 14 \\
\hline S15 & Spill Bay 15 \\
\hline S16 & Spill Bay 16 \\
\hline S17 & Spill Bay 17 \\
\hline S18 & Spill Bay 18 \\
\hline S19 & Spill Bay 19 \\
\hline S20 & Spill Bay 20 \\
\hline S21 & Spill Bay 21 \\
\hline S22 & Spill Bay 22 \\
\hline S23 & Spill Bay 23 \\
\hline
\end{tabular}



Appendix B

Estimating the Additional Contribution of

"Dead-Fish Releases" to the Overall

Variance of Project Survival Estimates 



\title{
Appendix B
}

\section{Estimating the Additional Contribution of "Dead-Fish Releases" to the Overall Variance of Project Survival Estimates}

\author{
Prepared for: \\ Gene R. Ploskey \\ Battelle Pacific Northwest National Laboratory \\ P.O. Box 241 \\ North Bonneville, Washington 98639
}

\author{
Prepared by: \\ John R. Skalski \\ Rebecca A. Buchanan \\ Columbia Basin Research \\ School of Aquatic and Fishery Sciences \\ University of Washington \\ 1325 Fourth Avenue, Suite 1820 \\ Seattle, Washington 98101-2509
}

18 December 2007 


\section{B.1 Introduction}

Tagged dead fish that pass through Bonneville Dam and are detected downriver must be accounted for in estimation of project or dam passage survival. To adjust for this potential source of positive bias, releases of "tagged dead fish" must be conducted to independently estimate the probability that such fish float downriver and are subsequently detected. This report addresses the issue of how many "tagged dead fish” must be released $(n)$ to retain a precise estimate of project survival.

\section{B.2 Methods}

The bias-adjusted, paired-release estimates of project/dam survival $(\tilde{S})$ has a variance composed of two components as follows:

$$
\operatorname{Var}(\tilde{S})=\operatorname{Var}_{\hat{D}}(E(\tilde{S} \mid \hat{D}))+E_{\hat{D}}(\operatorname{Var}(\tilde{S} \mid \hat{D}))
$$

The first component is the contribution associated with estimating the dead fish detection probability $(\hat{D})$ and the second component is the contribution from the paired release-recapture model estimation of project survival $(S)$. For a paired release-recapture study with two downstream detection sites, the bias-adjusted estimator of survival can be written as

$$
\tilde{S}=\frac{\left[\frac{n_{1}+n_{3}}{R_{1}}-D\right]}{\left[\frac{n_{1}}{n_{1}+n_{2}}-D\right] \hat{S}_{2}}
$$

where

$R_{1}=$ release size for upstream group

$n_{1}=$ number of fish from release $R_{1}$ with history 11

$n_{2}=$ number of fish from release $R_{1}$ with history 01

$n_{3}=$ number of fish from release $R_{1}$ with history 10

$\hat{S}_{2}=$ estimated survival of fish from downstream release $R_{2}$ to the first detection array. 
In expectation, $\tilde{S}$ has the value

$$
E(\tilde{S} \mid \hat{D})=\frac{S_{1}+\left(1-S_{1}\right) \hat{D}-\frac{\hat{D}}{p}}{S_{2}\left(1-\frac{\hat{D}}{p}\right)}
$$

where

$S_{1}=$ survival of fish from upstream release $R_{1}$ to the first detection array

$S_{2}=$ survival of fish from downstream release $R_{2}$ to the first detection array

$p=$ probability of detecting a tagged fish at the first array

$D=$ probability a dead fish from release $R_{1}$ migrates and is detected at the first array

such that, if $D=0, \tilde{S}=\frac{S_{1}}{S_{2}}=S_{\text {Project }}$.

The variance of Eq. (3) with respect to $\hat{D}$ can be estimated by the delta method to be

$$
\operatorname{Var}_{\hat{D}}[E(\tilde{S} \mid \hat{D})]=\frac{D(1-D)}{n}\left[\frac{\left[\left(1-S_{1}\right) p-1\right]}{S_{2}(p-D)}+\frac{\left[S_{1}^{2} p+S_{1}\left(1-S_{1}\right) D p-S_{1} D\right]}{S_{2}^{2}(p-D)}\right]
$$

where $n$ = number of dead tagged fish released below the dam. Using Eq. (4), the contribution of estimating the dead-fish detection rate $(D)$ on the overall variance of a project survival (1) estimate can be calculated. The square root of Eq. (4) provides a rough approximate value of how much the standard error (SE) of a project survival estimate will increase due to dead-fish detections, because

$$
\sqrt{\sigma_{1}^{2}+\sigma_{2}^{2}}<\sqrt{\sigma_{1}^{2}}+\sqrt{\sigma_{2}^{2}}=\sigma_{1}+\sigma_{2}
$$

A more accurate interpretation is to add the value of Eq. (4) to the anticipated variance of $\hat{S}$ without dead-fish problems and then take the square root of the sum to see what the expected SE might be with release size $n$.

\section{B.3 Results}

One release-recapture scenario was investigated using Eq. (4) (Figure B.1). The scenario consisted of a paired release above and below Bonneville Dam with two downstream detection arrays. It was assumed that dead, tagged fish might be detected at the first array but not at the second. Reach survivals were set at $S_{1}=0.83, S_{2}=0.87$ for a paired survival value of $S_{1} / S_{2}=0.95$. Detection of the first array was set at $p=0.80$, consistent with values observed in 2006 . 
The square root of Eq. (4) (i.e., appropriate additional contribution to SE of $\hat{S}_{\text {Project }}$ ) was plotted against the release size $(n)$ of dead, tagged fish for various values of $D=0.01,0.05, \ldots, 0.30$. Results indicate (Figure B.2) sample size can be quite large if the contributions to the overall SE $(\hat{S})$ are to be small. For example, if $D=0.05$, release size must be $n=100$ for the SE of the survival estimate to be inflated by 0.01 . For the SE of the project survival to be inflated by no more than 0.005 when $D=0.05$, release size of dead, tagged fish is $n \approx 500$. Release sizes increase substantially as the value of $D$ increases.

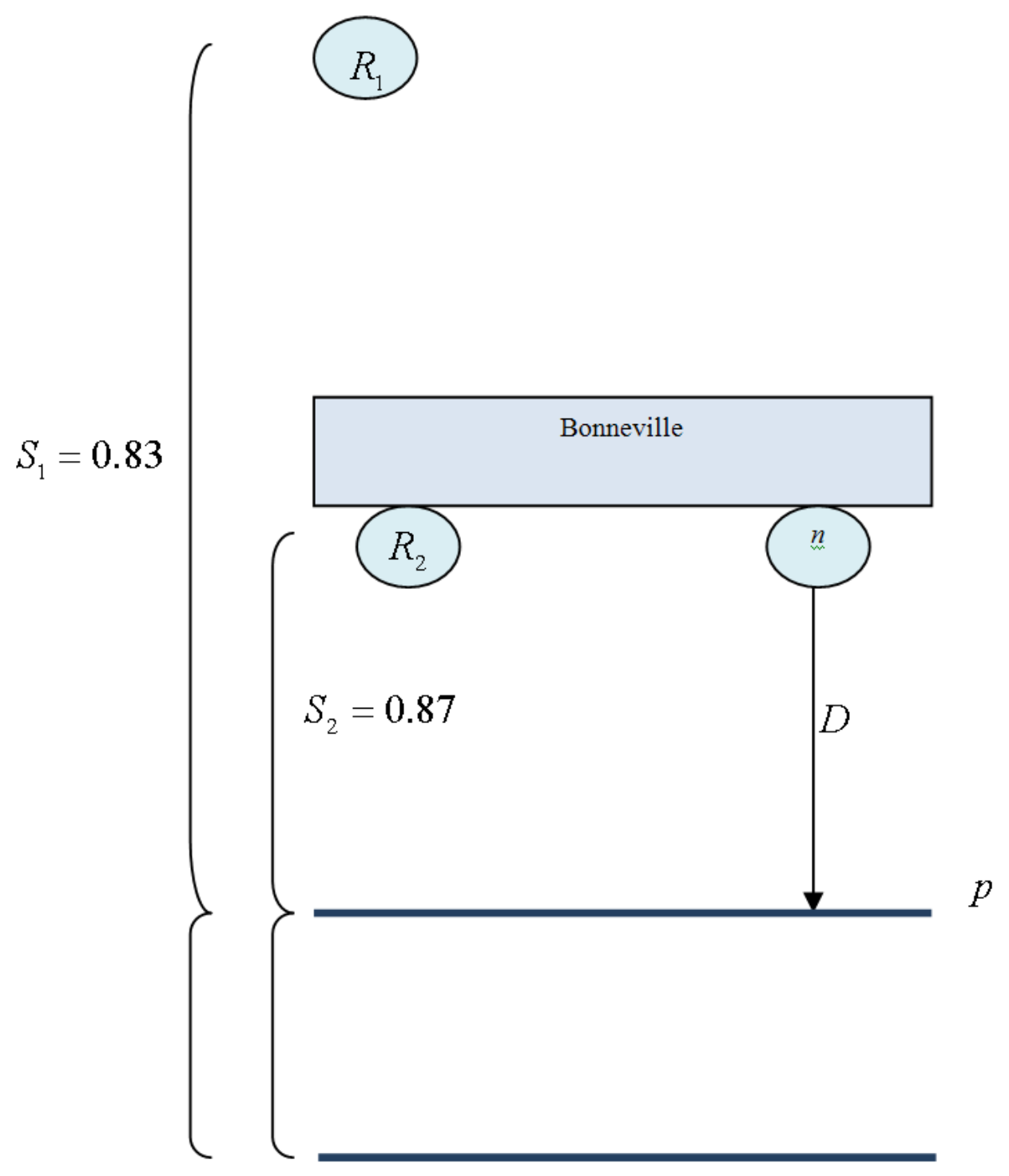

Figure B.1. Schematic of Paired Release-Recapture Scenario Used in Sample Size Calculations 
a. Release size $n$ where $n \leq 100$

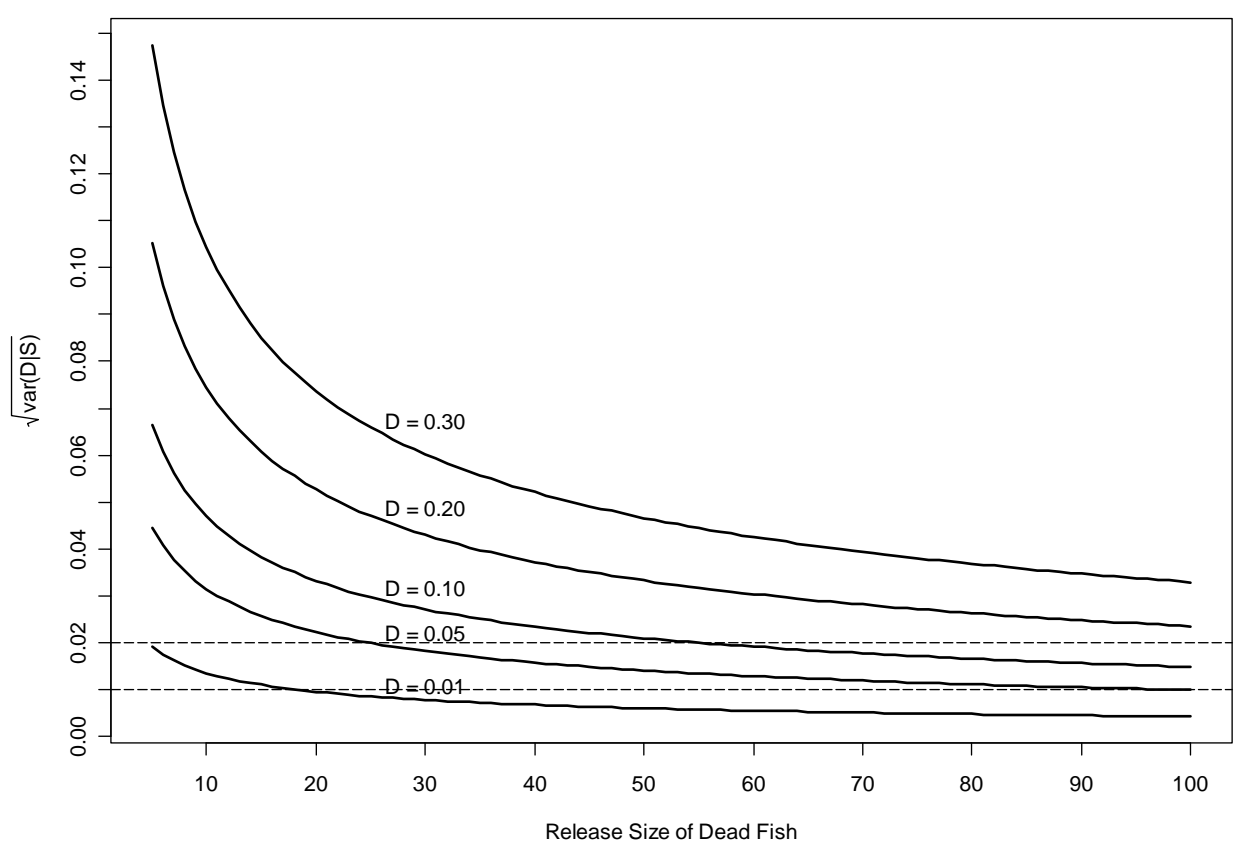

b. Release size $n \geq 100$

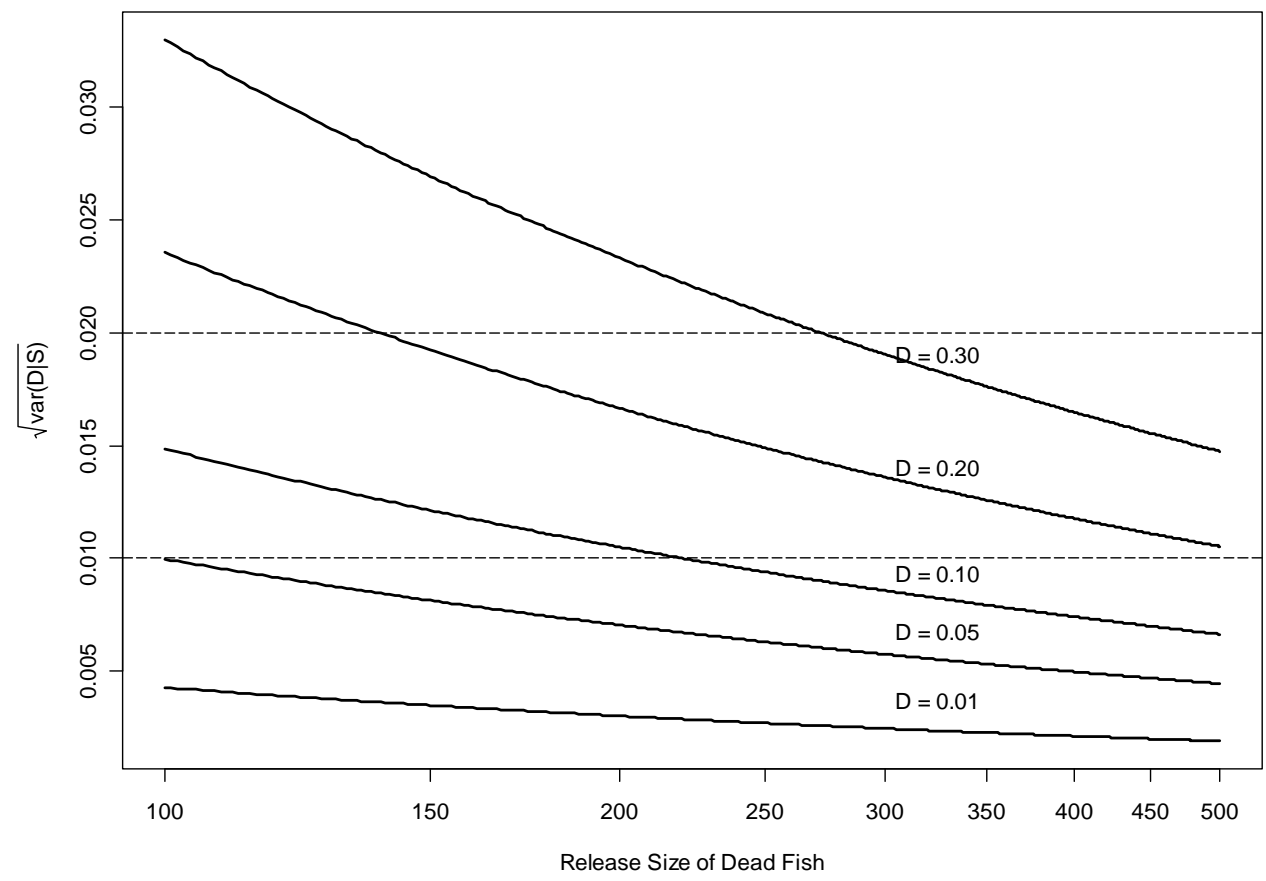

Figure B.2. Appropriate Additional Contributions to the Standard Error of Project Survival Estimates as a Function of the Number of Dead, Tagged Fish Released (n) and the Probability that a Dead Fish Migrates to and Is Detected at the First Downstream Array (D) for (a) and (b) 



\section{Distribution}

No. of

Copies

OFFSITE

29 Dennis Schwartz

USACE District, Portland

CENWP-PM-E

333 SW $1^{\text {st }}$ Ave (R. Duncan Plaza)

Portland, OR 97204-3495

12 Gene Ploskey

P.O. Box 241

North Bonneville, WA 98639

1 Brad Eppard

CENWP-PM-E

333 SW $1^{\text {st }}$ Ave (R. Duncan Plaza)

Portland, OR 97204-3495

1 Robert Johnson (PDF only)
No. of

Copies

ONSITE

4 Pacific Northwest National Laboratory

Hanford Technical Library (2) P8-55

Dennis Dauble

(PDF)

David Geist

Distr.1 




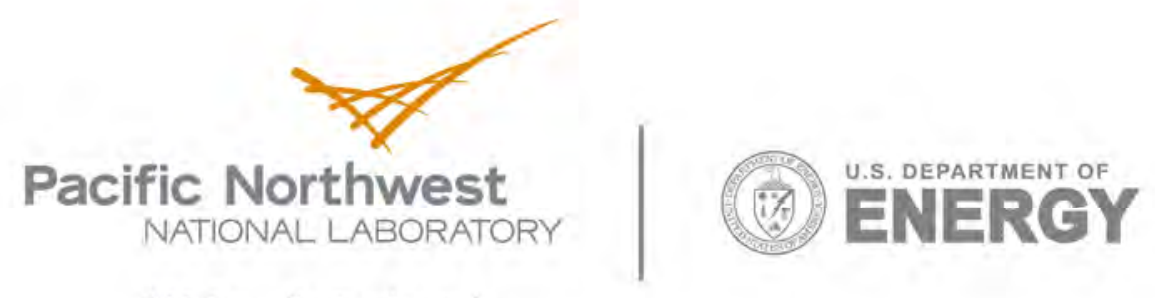

902 Battelle Boulevard

P.O. Box 999

Richland, WA 99352

1-888-375-PNNL (7665)

www.pnl.gov 